Playing On: Re-staging the Passion after the Death of God 


\title{
Theology in Practice
}

\author{
Editors-in-Chief \\ Bonnie J. Miller-McLemore (Vanderbilt University) \\ Elaine Graham (University of Chester)
}

Editorial Board

Tom Beaudoin (Fordham University)

Eileen Campbell-Reed (Union Theological Seminary, New York City)

Joyce Ann Mercer (Yale Divinity School)

Anthony Reddie (University of South Africa)

Phillis Sheppard (Vanderbilt University)

Claire E. Wolfteich (Boston University)

VOLUME 10

The titles published in this series are listed at brill.com/thip 


\section{Playing On: \\ Re-staging the Passion after the Death of God}

By

Mirella Klomp

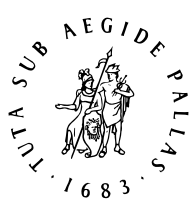

B R I L L

LEIDEN | BOSTON 
This is an open access title distributed under the terms of the CC BY-NC 4.o license, which permits any non-commercial use, distribution, and reproduction in any medium, provided the original author(s) and source are credited. Further information and the complete license text can be found at https://creativecommons.org/licenses/by-nc/4.o/

The terms of the cc license apply only to the original material. The use of material from other sources (indicated by a reference) such as diagrams, illustrations, photos and text samples may require further permission from the respective copyright holder.

Cover illustration: 2016 edition of The Passion, Amersfoort, (c) EO/Michaël Terlouw. Reproduced with kind permission.

The Library of Congress Cataloging-in-Publication Data is available online at http://catalog.loc.gov

Typeface for the Latin, Greek, and Cyrillic scripts: “Brill". See and download: brill.com/brill-typeface.

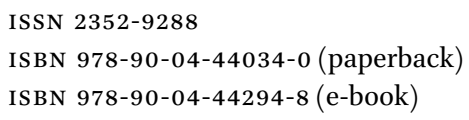

Copyright 2020 by Mirella Klomp. Published by Koninklijke Brill NV, Leiden, The Netherlands. Koninklijke Brill NV incorporates the imprints Brill, Brill Hes \& De Graaf, Brill Nijhoff, Brill Rodopi, Brill Sense, Hotei Publishing, mentis Verlag, Verlag Ferdinand Schöningh and Wilhelm Fink Verlag. Koninklijke Brill NV reserves the right to protect this publication against unauthorized use.

Brill has made all reasonable efforts to trace all rights holders to any copyrighted material used in this work. In cases where these efforts have not been successful the publisher welcomes communications from copyright holders, so that the appropriate acknowledgements can be made in future editions, and to settle other permission matters.

This book is printed on acid-free paper and produced in a sustainable manner. 
For Swaentje and Jasmijn 
If anything is dead, it is a 'traditional' idea of God

Trust no theory, no religious history or creed, in which the author's personal faith is not actively at risk CHRISTIAN WIMAN, My Bright Abyss 


\section{Contents}

Preface XI

List of Charts, Figures and Tables $\mathrm{XV}$

Prologue 1

Beyond the Belief That God Is Dead 1

In Public Discourses God Still Seems Dead 3

After the Death of God: A New Quest for God 6

The Place of the Case in This Book 10

Metaphors and the Structure of the Book 13

Authorship 17

Positionality Statement $\quad 18$

PART 1

Setting the Stage

1 The Play: A Popular Passion in the Public Sphere 23

Initiative and Development $\quad 25$

The Ritual: Fixed Format, Liquid Aspects 29

Format 30

Liquid Aspects 35

Producers: Shaping the Ritual 38

Public: People and Their Reception 43

Who Watches The Passion and What Do They Think of It? 44

Viewers'Social-Structural Characteristics $\quad 46$

Church Background/Affiliation 48

General Ideological Traits 49

Spirituality $5^{\circ}$

Collective Cohesion $\quad 51$

Conclusion 51

2 The Scenery: Dwellings in a Sacro-Soundscape 53

The Changing Religious Landscape 55

Transfer and Transformations of Passion Practices $\quad 5^{8}$

The Sonic Aspects of Religion 65

Appadurai's Five-Scapes 66

McAlister's Religioscapes and Tweed's Sacroscapes 66 
Soundscapes in Acoustemology and Theology 67

Sacro-Soundscapes 69

The Study of Sacro-Soundscapes 71

Conclusion 72

3 The Re-Appearance of God: Ana-Liturgy 74

The Procession 77

The Procession in The Passion 77

Historical Background and Cultural Context 80

A Return to God after God: Kearney's 'Anatheism' 82

Encountering God in Ana-Liturgy 86

Empowering Powerlessness: Firemen in the Physical

Procession 86

Letting Go of God:A Lamenting Mother on the Second Screen 89

An Epiphanic Tweet: A Grandmother Joining the Twitter-Hashtag

Procession 90

Conclusion $\quad 91$

PART 2

\section{Cross-Fading Perspectives on the Play}

4 Claiming Sacred Ground: A Spatial Practice 95

Space, Place and the Sacred 98

The Passion as Spatial Practice 100

Physical Space 101

Ritual Space 101

Musical Space 102

Mental Space: Appropriation 103

Contested Ground and Multidimensional Space 105

The Market Square: Object of City Marketing versus Business

Interest 106

A Musical Event: Vehicle for Evangelisation or an Entertainment

Show? 108

The Separation of Church and State at Stake 110

Conclusion 112

Side Light: Locus Iste. A Meditation 114 
5 Playing with the Sacred: A Ludic Practice 119

Religious Changes in Late-Modern Societies 122

Religion and Play 124

Ludification of Culture 125

The Passion as Ludic Practice 127

General Observations 128

The Dutch Queen of Plastic Surgery in the Role of the Servant Girl 129

After His Arrest Jesus Christ Appears in an Iconic Orange Jumpsuit 131

An Accused Actor in the Role of Barabbas 132

Conclusion 134

Side Light: @deusludens. A Twitter Thread 136

6 Dealing with Society's Secular Self-Understanding: A Reflexive Practice 138

Exploring Uncertainties around National Identity 141

Background: From Secular to Post-secular in European Public Life? 144

The Passion as Public Reflexivity 147

An Image of Jesus 148

Jesus in an Orange Jumpsuit: Islamic Terrorist or Christian

Victim? 150

The Morality of the Actors 156

Conclusion 159

Side Light: Reflections in a Mirror. A Meditative Exegesis $\quad 163$

7 Staging the Resurrection: A Public Theological Practice 166

Staging the Resurrected Jesus 168

Introductions to the Finale 168

Gouda $2011 \quad 170$

Groningen $2014 \quad 172$

Dordrecht $2019 \quad 174$

Production and Broadcasting Companies Doing Theology $\quad 176$

Public Theology as a Multi-Actor Practice 178

Ritual Criticism 180 
Side Light: What Is This All About? A Letter 184

The Passion Shows That the Impossible Is Possible 184

Being Turned into Guests 185

\section{PART 3}

Full-Up Finish

8 Playing On: Practical Theology after the Death of God 189

Religion as a Practice of Negotiation 189

And What about God? 191

God's Play 192

Aspects of Loss 194

Performing Practical Theology after the Death of God 196

Practical Theology as Public Theology 200

Practical Theology as Play 201

Appendix 1: Research Methodology 205

Qualitative Research 205

Meta-Theoretical Choices 206

An Ethno-Case Study 208

Methodological Account of Empirical Research $\quad 212$

Participant Observation in the Square and on TV 212

Semi-Structured Interviews and Informal Conversations $\quad 212$

Digital Documents 214

Online Data Sources 214

Entering and Exiting the Field 215

Appendix 2: Tables 217

Bibliography 226

Index 246

Permissions $\quad 251$ 


\section{Preface}

A choir rehearsal in an Amsterdam church building on the Saturday before Holy Week. I am taking part in an ad hoc amateur choir that is to perform J.S. Bach's Matthäuspassion at the end of the day. During the break, the professional baritone soloist who will be singing the role of Christ comes to me and asks: "Didn't I see you in the Concertgebouw yesterday?" He is right to recognize me: I am here for fieldwork, and had been at the Concertgebouw the day before, attending a rehearsal of the same Passion performed by professionals. The baritone had seen me interview members of the Royal Concertgebouw Orchestra and the Netherlands Radio Choir (the choir of which he was a part).

I smile at his question, because it immediately reminds me of that famous scene in the Christian passion narrative in which Peter is recognised for the third time as one of Jesus' followers: "Did I not see you in the garden with him?" Now I am recognised - by Christ, of all people! - and we exchange phone numbers so that I can contact him later on for an interview.

Later the same week, I am in Rotterdam with two colleagues for participant observation at an open-air passion event that will be broadcast live on national television. At one point during the show we stand in the path of the camera, which catches us singing along with one of the pop songs. After the show, I find that I have received a text message from the baritone: "WTF! I turn on the telly, first thing I see is you coming in the shot!"

This series of events occurred in 2012, two years into my research project on contemporary musical performances of passions in the Dutch cultural domain, and, during this busy week, I engaged in fieldwork on far more than just these three passions. Despite the efforts of some to liberate passion performances from the Christian liturgical calendar, most passion concerts still take place during Lent, especially Holy Week. So, I found myself immersed in the field, and there were plenty of opportunities for fieldwork at multiple passion performances every day.

Research in such a rich field, of course, had its limits: it was impossible to investigate every single passion performance in depth, so the project demanded more focus. A natural choice was to concentrate on the passion that had grown the largest, and which would continue to grow further in the years that followed - a passion that, contrary to other, sometimes modern, classical music passions that were performed in classical concert halls, stood out for its inextricable link with contemporary popular culture, the public sphere, and the street: The Passion. This book is the result of that particular focus. It sheds light on one particular rendition of the narrative of the suffering, death and 
even (although strictly not part of the passion narrative) the resurrection of Jesus Christ. Through that, the book offers a number of perspectives on how (Christian) religion has changed in the Netherlands over recent decades.

I want to extend my gratitude and thanks to those who played a part in the process that eventually led to the book. I should start by saying thank you to my colleagues at the Department of Culture Studies at Tilburg School of Humanities (Tilburg University), since I embarked on my research on the ritualmusical appropriation of passions in Dutch culture in 2010 in their midst. I did so as a post-doctoral researcher on the project Religion? Music! which was originally conceived by Martin Hoondert. Martin gave me the necessary space to find my own focus, and eventually to zoom in on the passion. I should also mention, at this point, Paul Post who, whilst sparing in his use of words, has always encouraged me to find my own pathway through academia. I am grateful for the opportunities they both gave me. I also owe a word of thanks to my colleagues in the Practices research programme at the Protestant Theological University, with whom I continued my passion research within the project Passio Resurrexit in 2013 and where I adopted a more theological outlook. I want expressly to thank our sociologists of religion Joep de Hart and Marten van der Meulen who supported me with endless and indispensable sociological expertise, and my colleagues in the chair of Practical Theology in Amsterdam who have kindly hassled me with their critical questions, discussion, and feedback over the past few years. Special thanks to Marcel Barnard for his ongoing encouragement to develop cutting-edge research, and to Rein Brouwer, Joyce Rondaij, Lydia van Leersum-Bekebrede and former PThU-colleague Jos de Kock who, at different stages, read in detail and advised me on different portions and versions of this manuscript. I also wish to express my gratitude to the Dutch Lutheran Foundation 'Stichting Luthers Diakonessenhuis Fonds' for their financial support, as well as the rector of PThU, Mechteld Jansen, and to say how much their continuous confidence in me is appreciated! Outside of PThU, I want to thank Erin Wilson at the University of Groningen, who was kind enough to let us recruit her ReMa-student Anita Zijdemans for ethnographic research in Enschede, and I am grateful for Anita's dedication and the data she collected. All-round theologian Peter-Ben Smit (vu University/Utrecht University/University of Bern) and Rev. Eddy Reefhuis, with his knowledge of Bible and rabbinic teaching, both deserve special mention for being such fabulous and constructive sparring partners in creative biblical hermeneutics. I say thank you to international colleagues to whom I presented some material in this book at meetings of the Societas Liturgica, at Christian Congregational Music conferences, and at the 'Conversations after God'-consultations of PThU and the Theological Faculty of the University of Pretoria. I benefitted greatly 
from the comments and suggestions of many scholars and practitioners that I received on those occasions. They have been very encouraging.

I am tremendously grateful for various informants in the field, without whom this research could never have taken place, particularly those from the audience who chatted with me in the squares where The Passion was staged. I am grateful for the support and hospitality of many individuals at the broadcasting companies KRO-NCRV and EO (as well as KRO-NCRV's predecessor RKK that initially embarked upon the project), and the production company Eye2EyeMedia (later: Mediawater) who were incredibly kind in providing me with all kinds of information, statistics and photographs, who cooperated in interviews, and who allowed me to attend their meetings. I cannot name them all here, but I want to mention Reinder van Dijk, Jacco Doornbos, Leo Fijen, Maddy Christine Hope (in New Orleans) and Arjan Lock in particular.

My co-authors Marcel Barnard, Martin Hoondert, Marten van der Meulen, Erin Wilson and Anita Zijdemans let me recompose previously published texts without any restrictions, and I thank them for their confidence in me. I here also want to acknowledge my protégé (Habilvater) during the course of my habilitation at the Theological Faculty of the University of Bern, David Plüss, to whom I give thanks for his advice, support and guidance. I am grateful to him and to Gutachterin Andrea Bieler and Gutachter Thomas Schlag, for their reviews of the manuscript, and to the former Dean of the Faculty, Angela Berlis, for guiding me through the Habilitationsverfahren. For their constructive criticism of earlier drafts and thoroughgoing feedback on the manuscript I offer a special thank you to the chief editors and series editors of Theology in Practice and their reviewers. I also want to offer a word of thanks to Ingrid Heijckers-Velt for her patience, instruction and support throughout the writing and publication process. I am thankful that Hijme Stoffels and Hans-Peter van Velthoven let me reproduce their photographs. I owe a lot to Mark Porter, who meticulously edited the English text, and to our former student-assistant Esther van Bijsterveldt, for her dedicated work on the bibliography and footnotes.

The road to the completion of this manuscript has been bumpier than any publication process I have been part of so far. The main obstacle on the road was a life-threatening illness that has driven my research subject into my personal life in a way I wish I would never otherwise have experienced. If it were not for the medical staff, and a circle of close colleagues, friends and family who have surrounded me during this period and kept me alive, this book would never have seen publication. For their care and support I am grateful beyond words. I want, in particular, to mention my good friends Eddy Reefhuis, Paul Sheppy, who kept me going during this period of turbulence. I thank my 
mother, and Jacco, Swaentje and Jasmijn Calis for their love and their generosity (they gave me so much time and space to write).

This book is dedicated to my daughters, who grow up in a society where Christian religion is rapidly changing, and where the quest for God may well become even more challenging than it has been for me. 


\section{Charts, Figures and Tables}

\section{Charts}

$1 \quad$ Frequency of viewing classified by the number of situations in which respondents claim to have felt united with other Dutch people 45

2 Viewers who have watched The Passion at least once, according to birth cohort (percent) $\quad 46$

3 Appreciation of The Passion among those who have watched one or more times, according to birth cohort (percent) 47

\section{Figures}

$1 \quad$ Viewing figures of The Passion for respective editions 25

2 The H.J. Van Heek Square in Enschede where the main stage for The Passion was erected in 2015. Photo: Michaël Terlouw. (C) EO. Reproduced with permission of EO's Marketing \& Communication Dpt. $\quad 26$

3 Singer Do as Mary, the mother of Jesus. The Passion in Gouda, 2011. Photo:

(C) Hijme Stoffels. Reproduced with permission 33

4 The words 'Crucify him!!!!' over the face of Jesus on the projection screen at the Market Square in Gouda, 2011. Photo: @ Hijme Stoffels. Reproduced with permission 34

5 The temporary dwelling of a passion performed on the Grote Markt in the city of Groningen in 2014. Photo: Willem-Jan de Bruin. (c) Eo. Reproduced with permission of EO's Marketing \& Communication Dpt. 70

6 Overview of round numbers of participants in the virtual procession on the second screen 79

7 Firemen carrying the neon-lit cross. Photo: Rogier van den Berg. (C) RTV Oost. Reproduced with permission of RTV Oost 88

8 The procession with the cross passing the audience in the Market square in the city of Gouda while making its way to the main stage. Photo: (C) Hijme Stoffels. Reproduced with permission 102

9 Mental spaces that may influence the appropriation of The Passion 105

10 Pictures from the second photo shoot with Jesus, 2015. Photo: (C) Hans-Peter van Velthoven. Reproduced with permission 149

11 The Jesus character in an orange coverall with two soldiers after his conviction in The Passion, Enschede, 2015. Photo: Arianne Ramaker. (C) EO. Reproduced with permission of Eo's Marketing \& Communication Dpt. $\quad 151$ 
12 Christian victims of Is Is led to their execution on a Libyan beach. Screenshot from a YouTube-video posted by Isis on February 16, $2015 \quad 15^{2}$

13 Poster for the Pandora Foundation 164

14 Television director David Grifhorst in the mobile production unit in 2015. Screenshot from a Youtube-video. Image: EO/KRO-NRCV $\quad 167$

15 Singer Syb van der Ploeg as the resurrected Jesus on the tower of the St Jan's Church in Gouda. Photo: (C) ANP 171

16 The resurrected Jesus (by singer Jan Dulles) appearing amongst people in the square in the 2014 edition of The Passion. Screenshot from the online broadcast of The Passion. Image: EO/KRO-NRCV 174

17 The resurrected Jesus (by Edwin Jonker) appearing on top of the Dordrecht Minster above the square in the 2019 edition of The Passion. Screenshot from the online broadcast of The Passion. Image: EO/KRO-NRCV 175

18 The online time-shifted viewing screen for The Passion in 2018 presented a number of video clips and broadcasts. From left to right: the talk show 'Passiontalk' (featuring me), the 2018 edition of The Passion, and three brief digital interviews with performers which were launched via socials in the days prior to the performance. Screenshot from www.npostart.nl. Image: NPO 213

\section{Tables}

$1 \quad$ Number of times that people watched the TV-broadcast of The Passion or attended the event $\quad 217$

2 Assessment of organisation and depiction of The Passion 217

$3 \quad$ Frequency of viewing and rating classified by viewers' characteristics 218

4 Assessment classified by social-structural characteristics (for viewers who have watched at least once) 219

5 Frequency of viewing and assessment classified by church background/ affiliation 220

$6 \quad$ Frequency of viewing and assessment classified by the number of situations in which people consider religion to have an important role 221

$7 \quad$ Frequency of viewing and assessment classified by the number of situations in which people consider religion to have an important role, in detail 222

8 Number of times that people watched the TV-broadcast of The Passion or attended the event in relation to their religious/spiritual self-identification 223

9 Assessment of organisation and depiction of The Passion in relation to people's religious/spiritual self-identification $\quad 223$ 
10 Frequency of viewing and assessment classified by spiritual interest and practices 224

11 Frequency of viewing and assessment classified by situations in which respondents feel united with other Dutch people $\quad 225$ 
Mirella Klomp - 978-90-04-44294-8 Downloaded from Brill.com04/26/2023 09:16:19AM via free access 


\section{Prologue}

\section{Beyond the Belief That God Is Dead}

The Netherlands has a stubborn image as one of the most secularised countries in Western Europe. On international journeys, I frequently find myself being asked to confirm to people that, although my country still has churches and churchgoers, ministers and priests, and even theologians, Christianity is indeed receding in Dutch culture (in the same sentence I am also often asked to confirm that everyone in the Netherlands smokes pot, but that is not the topic of this book). A similar idea is all too often conveyed in Dutch public discourse: over recent decades, the Dutch have gradually left their Christian (predominantly Calvinist) roots behind, and their society is on the verge of attaining a, frequently glorified, secular status. ${ }^{1}$

Both examples reflect widely spread secularisation discourses in which the 'traditional' secularisation thesis seems still alive. This is, however, strikingly at odds with how scholars in the past two decades have come to think about religion and secularisation: they generally agree that the secularisation thesis, as a thesis, is dead. Many of them acknowledge that processes of secularisation (such as, e.g., 'internal secularisation': a secularisation of people's religious longing ${ }^{2}$ ) are going on, and that the rise of science and reason have caused large alterations in society that also affect religion, religious practices and religious affiliation. However, the thesis that religion dies out as modernisation progresses is and has overall been rebutted by scholars from various disciplinary backgrounds, such as, for example, the famous sociologist of religion Peter L. Berger, ${ }^{3}$ political scientists Pippa Norris and Ron Inglehart, ${ }^{4}$ and

1 On the debate regarding secularisation narratives in Western Europe in the 1950s, see Herman Paul, "The Sociological Myth. A 1954 Controversy on Secularization Narratives", Journal of Religion in Europe 9 (2016), 201-224. Paul mentions an observation by Dutch theologian Berkhof in 1954 that time and again church periodicals in the stories used formulations which included the words "still" and "no longer". "Pastors write that "part of the congregation still visits the Sunday service", while others complain that "the youth is no longer interested in matters of religion"”. Paul, "The Sociological Myth", 208.

2 Herman Paul, De slag om het hart. Over secularisatie van verlangen (Utrecht: Boekencentrum, 2017).

3 As long ago as 1999, Berger published a book entitled The Desecularization of the World. Resurgent religion and world politics. Berger, at that time, did not falsify secularisation theses, but claimed to have identified processes of counter-secularisation within cultures and societies. Cf. Peter L. Berger, The Desecularization of the World. Resurgent Religion and World Politics (Washington, D.C./Grand Rapids, MI: Ethics and Public Policy Center; Eerdmans, 1999).

4 In 2004, in their book Sacred and Secular. Religion and Politics Worldwide, political scientists Pippa Norris and Ron Inglehart stated that "secularization theory is currently experiencing

(C) MIRELLA KLOMP, 2020 | DOI:10.1163/9789004442948_002

This is an open access chapter distributed under the terms of the CC BY-NC 4.olicense, Klomp - 978-90-04-44294-8 
philosopher Charles Taylor. ${ }^{5}$ In the Dutch context, scholars who engage in empirical research on contemporary religious practices in the Netherlands have shown that religion has not disappeared, but has instead deeply altered. ${ }^{6}$ They have concluded that secular and the religious are not as opposed to each other as Western scholars long assumed. ${ }^{7}$

the most sustained challenge in its long history". Cf. Pippa Norris and Ron Inglehart, $\mathrm{Sa}$ cred and Secular: Religion and Politics Worldwide (Cambridge: Cambridge University Press, 2004), 3. They took an important step in revising the 'traditional' secularisation thesis, stating that in developed countries religious institutions and their authorities were indeed in decline, however, 'spiritual concerns' (relating to the meaning and purpose of life) were becoming increasingly important. Norris and Inglehart, Sacred and Secular, 75.

5 Charles Taylor in 2007 published A Secular Age, an ambitious work that would become a best-seller in which he addressed not so much the increasing marginalisation of religion from the spheres of public life, or the decline of religious belief and practices, but focused on what he calls a third type of secularity. This type does not so much point to an absence of religion, but rather to the fragmentation and continuing multiplication of new options to make sense of our world and to give shape to their spiritual ambitions, in a universe that does not turn around a central point. Charles Taylor, A Secular Age (Cambridge, MA: Harvard University Press, 2007), 2-3.

6 A landmark was the publication of a voluminous research report by The Netherlands Scientific Council for Government Policy (WRR; an independent advisory body for government policy) in 2006. Cf. Wim van de Donk, A.P. Jonkers, G.J. Kronjee and R.J.J.M. Plum, eds., Geloven in het publieke domein. Verkenningen van een dubbele transformatie, WRR Verkenningen 13 (Amsterdam: Amsterdam University Press, 2006), https://www.wrr.nl/publicaties/verkenningen/20o6/12/19/geloven-in-het-publiek-domein -verkenningen-van-een-dubbele-transformatie---13. Also see Joep de Hart, Paul Dekker and Loek Halman, Religion and Civil Society in Europe (Dordrecht: Springer, 2013). For a more extensive list of references, see Chapter 2.

7 In practical theology, this opposition has, for example, been countered by Elaine Graham in an interesting publication that deals with the legitimacy of religious voices in public life and develops proposals for a Christian apologetics of presence. Cf. Elaine Graham, Between a Rock and a Hard Place. Public Theology in a Post-Secular Age (London: SCM Press, 2013). Stephen Pattison had already emphasised, with reference to Don Browning, that faith, worldviews and belief systems not only inform the practices of religious, but also secular institutions. Cf. Stephen Pattison, The Challenge of Practical Theology. Selected Essays (London: Jessica Kingsley 2007), 11. Also cf. Tom Beaudoin (ed.), Secular Music and Sacred Theology (Collegeville, MN: Liturgical Press 2013), $\mathrm{x}$, where the editor mentions that his edited volume aims to demonstrate that and how (secular/popular) music is related to things religious, spiritual, sacred and/or to God. It is important to realize, however, that the religioussecular dichotomy is a contextual one. This contextuality must not be overlooked: the construction of a religious-secular divide has proven to be problematic in non-Western cultures and worldviews. Several practical theologians have, for instance, rightly emphasised the importance of recognising the differences between Western and African 'spiritual ontologies' (cf. Lars Charbonnier, Johan Cilliers, Matthias Mader, Cas Wepener and Birgit Weyel (eds.), Pluralisation and social change. Dynamics of lived religion in South Africa and in Germany 


\section{In Public Discourses God Still Seems Dead}

The thesis that unbelief rules out belief is kept alive in secularisation discourses, though, influenced by, among others, (secular) media and the attention they pay to quantitative research results that point to receding Christianity. In the wake of Friedrich Nietzsche's famous declaration: "God is dead. God remains dead. And we have killed him", ${ }^{8}$ news coverage on Christian religion often presents the Netherlands as a post-Christian nation and God as being incredibly dead in this country. ${ }^{9}$ This image was, for instance, on show in newspapers and TV and radio programs in March 2016, after the publication of the decennial quantitative study God in Nederland (GIN):

The Netherlands are no longer a Christian nation. This is the main conclusion of the research project God in Nederland that is undertaken among more than 2100 Dutch people by KRO once every ten years. A large

(Berlin: De Gruyter 2018), 3. DOI: 10.1515/9783110569810). South African practical theologian Jaco Dreyer has discussed the genesis of the secularisation theory and proposed the value of a 'constitutional theory' which he offers as a potentially more fruitful alternative. Cf. Dreyer, "Do we live in a secular world? An African perspective", in: Wilhelm Gräb and Lars Charbonnier (eds.), Secularization Theories, Religious Identity and Practical Theology. Developing International Practical Theology for the 21st Century (International Practical Theology, vol. 7) (Münster/Zürich: Lit Verlag 2009), 35-62. Reflecting on a particular public ceremony, Emmanuel Lartey demonstrated that a ritual organised by a government official in the environment of a secular state department, contributed to "postcolonialising God", thus vanquishing the (colonial) idea that religious activities are bound to religious institutions and religious people. Cf. Emmanuel Lartey, "Postcolonial African practical theology. Rituals of remembrance, cleansing, healing and re-connection”, Journal of Pastoral Theology 21/2 (2011), 1-17. DOI: 10.1179/jpt.2011.21.2.002. Also interesting in this respect is the fact that two Brazilian theologians saw opportunities for dialogue between the (British) Harry Potter literary series and the eucharistic liturgy, taking 'lived religion' as a hermeneutic instrument with which to connect religious experiences and pop cultural reflections with ecclesial or doctrinal discussions. Cf. Ivan Kiper Malacarne and Júlio Cézar Adam, "Comensais da morte ou da vida? Contribuições da religião vivida para a teologia cristã a partir da série literária Harry Potter" ("Death or life Eaters? Contributions of lived religion to Christian theology from the Harry Potter literary series"), Tear Online 8/2 (2019), 114-126.

8 Friedrich Nietzsche, The Gay Science $(1882,1887)$ par. 125; Walter Kaufmann ed. and transl. (New York: Vintage, 1974), 181.

9 Christian media form an exception: smaller national Christian newspapers like Nederlands Dagblad and Reformatorisch Dagblad do not share in this overall negative attitude towards religion. Other exceptions are a few particular journalists working for large national newspapers such as NRC Handelsblad and De Volkskrant, who occasionally show a more open attitude towards (Christian) religion when writing about religious matters. The most striking change of stances regarding Christian religion and church (from rather sceptical to more open) was observed in the past five years in the religion section of Dagblad Trouw. 
majority, 82 percent, never or hardly ever visits a church. And a large majority hold the opinion that religion should no longer play a determining role in politics and education. ${ }^{10}$

Quantitative investigations like these feed the secularisation discourse in Dutch society, because their results are as plain as day, and easy to convey: traditional Christian belief has crumbled in Dutch society, and the decline of church membership and church attendance that had started decades ago, has kept going: $71 \%$ of the respondents in 2016 had no affiliation with a church of religious group, $59 \%$ never attended church services (or other religious meetings) and $23 \%$ rarely did so. ${ }^{11}$ According to $52 \%$ of the respondents, religion is a personal matter that should be limited to the private sphere. ${ }^{12}$ The survey that was used in this research measured, among other things, to what extent people subscribed to Christian beliefs, whether people engaged in 'traditional' Christian practices such as prayer and reading the bible, or whether they performed other practices such as walking silent marches or lighting a candle for someone. Other quantitative research, e.g. by The Netherlands Institute for Social Research (SCP) and Statistics Netherlands (CBS), shows similar results. ${ }^{13}$

It is a known and irrefutable fact that the institutionalised church has faced tough times over the last decades and processes of 'de-churching' have progressed rapidly. Church buildings have been closed, sold or demolished and many Christian congregations and parishes have merged in order to consolidate numbers. There is lack of money, a lack of younger members, and a lack of volunteers to do all the ecclesial work. The 'traditional' way of living Christian faith is under pressure and no longer fits what many people are looking for. Despite churches' missionary initiatives, churches as well as Christian be-

10 ANP (Netherlands national news agency), "Hoe God (bijna) verdween uit Nederland", 13 March 2016. http://nos.nl/artikel/2092498-hoe-god-bijna-verdween-uit-nederland.html. Last accessed May 10, 2020.

11 The research God in Nederland was first conducted in 1966 by order of Dutch broadcasting company кRо, in order to investigate the condition of Christian religion in the Netherlands.

12 Ton Bernts and Joantine Berghuijs, God in Nederland 1966-2015 (Utrecht: Ten Have, 2016), 207-222.

13 Cf. Joep de Hart and Pepijn van Houwelingen, Christenen in Nederland. Kerkelijke deelname en christelijke gelovigheid (Den Haag: Sociaal en Cultureel Planbureau, 2018); Schmeets, Hans, Wie is religieus en wie niet? Statistic Trends (CBs), oktober 2018 (PDFfile), obtained via https://www.cbs.nl/nl-nl/achtergrond/2018/43/wie-is-religieus-en-wie -niet-. Last accessed May 10, 2020. 
liefs are in a critical condition. ${ }^{14}$ This decline ought to be seen as part of a broader, Western situation; ${ }^{15}$ the decrease of institutionalised Christianity is not distinctively Dutch, as research on, for example, Britain ${ }^{16}$ and the USA shows. ${ }^{17}$ Those who form their judgments purely on the basis of such quantitative research reports cannot but conclude that in the Western world, institutionalised Christianity religion is in fact disappearing.

14 In the last decade, a strong missionary wind has risen in churches of various denominations. E.g. in the Protestant Church in the Netherlands (that had around 1.85 million members on 1 January 2017), where some 100 "pioneer projects" throughout the country were initiated in order to search for new, and more diverse forms of being church that intend to bring the gospel to more and different people than those who are already involved in and/or part of church congregations. Source: "Statistische jaarbrief en tabellenboek 2017.pdf", Protestantse Kerk in Nederland. https://www.protestantsekerk .nl/data/import/cb2cfc1245f8b6ao7o91ao975e4752oe.pdf. Last accessed May 10, 2020. Another example is the smaller Reformed church denomination Gereformeerde Kerken vrijgemaakt, that in 2015 also initiated second generation church planting projects. Source: "GKv werkt mee aan 40-tal kerkplantingsprojecten", Gereformeerde Kerken vrijgemaakt. https://www.gkv.nl/gkv-werkt-mee-aan-4o-tal-kerkplantingsprojecten/. Last accessed October 4, 2019.

15 A global perspective on Christianity shows deep changes. Contrary to a decline in the West, Christianity in the global south (Africa, Asia, and Latin America) is seeing an explosive expansion. Cf. Philip Jenkins, The Next Christendom. The Coming of Global Christianity (Oxford: Oxford University Press, 2002).

16 Britain, for example, was transformed, in the second part of the 2oth century, from a predominantly Christian society into a much more secular one. Cf. Callum G. Brown, The Death of Christian Britain: Understanding Secularisation, 1800-2000, Christianity and Society in the Modern World (London: Routledge, 2001), 1. (Grace Davie, however, in 2015 pointed to the paradox that, at the same time, religion is increasingly present in the public debate in the UK. Cf. Grace Davie. Religion in Britain. A Persistent Paradox (Chichester: Wiley-Blackwell, 2015).) In 2010, a British social research centre reported that "Britain is becoming less religious, with the numbers who affiliate with a religion or attend religious services experiencing a long-term decline". Cf. Alison Park, et al., British Social Attitudes report 28 (London: Sage, 2010), 173. The report is based on research executed by NatCen Social Research, a large centre for independent social research, "Losing faith?". NatCen Social Research, http://bsa.natcen.ac.uk/latest-report/british-social-attitudes-28/religion .aspx. Last accessed May 10, 2020. According to this report, $50 \%$ of respondents had no religious affiliation (against $31 \%$ in 1983 ), and only $14 \%$ of those with a religious affiliation attended religious services or meetings on a weekly basis.

17 In the US, a similar trend can be seen, although percentages are very different: in 2014, the Christian share of the US population dropped to $70 \%$ (from $78 \%$ in 2007), and the category of religious 'nones' (the unaffiliated, who see themselves as atheist, agnostic or 'nothing in particular') grew from $16 \%$ to almost $23 \%$ in seven years. Cf. Pew Research Center. "America's Changing Religious Landscape”. May 12, 2015. Washington D.C. Pew Forum on Religion and Public Life. Complete report available at http://www.pewforum .org/2015/o5/12/americas-changing-religious-landscape/. Last accessed May 10, 2020. 


\section{After the Death of God: A New Quest for God}

This book ties in with academic research that establishes transformations of religion, and explores how the transformation of Christian religion has taken shape in Dutch society, by investigating a particular ritual in the public sphere. This exploration takes an 'anatheistic' approach (see below) and adds to the question how or where God can happen in rituality after the death of God. The thread that runs through this study thus connects to two academic discourses (however to unequal extents): it aligns itself with research in Ritual and Liturgical Studies, which is the major focus, and it relates to 'the God-question' and discussions revolving around that topic in the fields of systematic theology and the philosophy of religion.

In the fields of Ritual and Liturgical Studies, over the last decade, there has been a research focus on ritual practices and the shifting location of sacrality. Whereas the sacred has long been found predominantly in liturgical ritual and the ecclesial domain, sacrality today is encountered in ritual practices in many other domains. This has led ritual studies scholar Paul Post, for example, to distinguish various fields of the sacred: the religious field, the field of healing, of memorial culture, of culture, of leisure culture - all of which are ritual-sacral 'areas' of practices interacting with places, locations, ideas and ideals, dreams and visions. ${ }^{18}$ 'Sacred', in this approach, is not necessarily synonymous with 'religious': the sacred is not limited to the religious field, nor to religion, neither is the 'secular' domain (e.g. the public sphere, or nature) necessarily excluded from sacred meaning-making and practices. ${ }^{19}$ The sacred in discourses of sacrality has broadly come to be approached as a construction, in various disciplines it has come to be taken as "an actively constructed value within a particular meaning system, from which people in turn mix and match elements to their own convenience and liking". ${ }^{20}$ Kees de Groot, a Dutch sociologist, has taken up this point in a number of Dutch case studies that sketch

18 Paul Post, "Fields of the Sacred", in Sacred Places in Modern Western Culture, eds. Paul Post, Arie L. Molendijk and Justin Kroesen (Leuven: Peeters, 2011), 13-59, here 38.

19 Gordon Lynch, whose work we will refer to in Chapter 4 and Chapter 6, distinguishes between religion and the sacred in a neo-Durkheimian attempt to disentangle the concepts of the religious and the sacred that have often been confounded in social theory. Cf. Gordon Lynch, The Sacred in the Modern World. A Cultural Sociological Approach (Oxford: Oxford University Press, 2012) for an extended argument on the distinction between the two concepts.

20 This is further elaborated in Lieke Wijnia and Mirella Klomp, "Tarenskeen's Luther: Allowing for New Forms of Sacrality", Jaarboek voor Liturgie-onderzoek 30 (2014), 243-259. 
the development of religion in transition, thus also refuting the idea that religion slowly disappears. He rather speaks of a liquidation of the church.21

A parallel development can be seen in systematic theology and the philosophy of religion, where newly arisen discourses have explored ways to rethink God. ${ }^{22}$ After 'the death of God', various scholars have ventured to think God anew, taking as a starting point unbelief in God, in the existence of God, and/or in the idea of God as a transcendent, sovereign, supreme being. The 'post-secular' has, according to systematic theologian Rick Benjamins, been a concept used to point "to some space, period, or context where the opposition between the religious and the secular as well as the demarcations between religious denominations are weakened or even surpassed, because we have left both the fixed outlines of institutionalised religions and the reductionist assumptions of secular and scientific reason". ${ }^{23}$ A number of post-secular thinkers have arrived at new perceptions of God under flags such as 'theothanatology', 'death-of-God-theology' or 'radical theology'. Richard Kearney, whose work I will use in this study, has for example developed, what he terms, a hermeneutics of the possible, thinking of God as a God who may be, instead of a God who is; as posse over esse ${ }^{24}$ as a God who may arrive in the welcoming of a stranger. ${ }^{25}$

As a practical theologian specialising in ritual and liturgical studies, I investigate the transformation of religion in a public sphere that may be described as 'post-Christian' and 'post-secular' at the same time and seek to understand this transformation as a new quest for God. ${ }^{26}$ It looks into a public ritual event

21 Kees de Groot, The Liquidation of the Church, Routledge New Critical Thinking in Religion, Theology and Biblical Studies (London: Routledge, 2017).

22 John Caputo, Richard Kearney, Jean-Luc Marion, Jean-Luc Nancy, and Thomas Altizer are some of the scholars who have engaged in these discourses.

23 Rick Benjamins, "The Postsecular and Systematic Theology: Reflections on Kearney and Nancy", International Journal of Philosophy and Theology 76, no. 2 (2015), 116-128, here 116.

24 Richard Kearney, The God Who May Be. A Hermeneutics of Religion, Indiana Series in the Philosophy of Religion (Bloomington, Ind., [etc.]: Indiana University Press, 2001).

25 Richard Kearney, Anatheism. Returning to God after God, Insurrections (New York: Columbia University Press, 2011).

26 At the Protestant Theological University in Amsterdam, where I am based, liturgical studies as a discipline comes under the aegis of practical theology. Amongst the broader tribe of liturgical scholars worldwide, the Dutch are well known for a strong ritual approach to liturgy: in the Netherlands, liturgical and ritual studies are often mentioned in one breath. The different renamings of the Dutch interfaculty 'Liturgical Institute' (founded in 1992) are striking in this respect, as it became the 'Institute for Liturgical and Ritual Studies' in 2009, and the 'Institute for Ritual and Liturgical Studies' in 2012. 'Ritual' has now taken primary position in the institute's self-description, indicating that, in a 
and poses the question how God can happen after the death of God, thus advancing Kearneys' anatheistic theory with a contribution from the field of practical theology, more particularly (liturgical-)ritual studies. This approach is fairly new: in the field of ritual studies scholars have studied the transfer and transformation of the sacred, yet without posing theological questions or engaging in theological discussions, and the anatheistic theory as introduced by Richard Kearney has not been explored much yet in studies of ritual, let alone of public ritual. ${ }^{27}$ His theory for a long time had a theopoetic and rather linguistic focus, as it mainly concentrated on texts (poems, and biblical as well as other narratives/stories; and to a lesser extent paintings). ${ }^{28}$ Delving deeply and empirically into a ritual in the public sphere, this study explores how God can happen again at a time where the 'old religion' apparently has come to fall short.

Like many other theories that were developed in the wake of the rebuttal of the secularisation thesis, this study connects to what sociologist Robert Wuthnow has described as the recent movement from a spirituality of dwelling, which emphasises habitation, in which God dwells in a sacred space where humans too can stay, to a spirituality of seeking, which emphasises negotiation, where individuals are convinced that the divine exists, but search for sacred moments to confirm and reinforce that conviction. ${ }^{29}$ God and the sacred are no longer fixed categories: they are at different times found, discovered, encountered. This practical theological study is itself a quest for God in

Dutch context, liturgy has become a much smaller domain of research than the broader field of rituality. The ritual approach to liturgy, which considers liturgy as action, performance, or practice more than as a 'thing', obviously suits its location within practical theology.

27 An exception is this PhD dissertation on (liturgical-)ritual music: Hanna Rijken, "My Soul Doth Magnify'. The Appropriation of the Anglican Choral Evensong in the Netherlands" (PhD diss., Protestant Theological University, Amsterdam, 2017), S.l., s.n.

28 After the publication of Anatheism, Kearney's theory has become widely appreciated and used by scholars in philosophy and theology for the interpretation and elaboration of various topics (e.g. 'corporality', 'otherness', 'imagination', as well as explorations of the return of the divine through particular (art) forms, practices such as literature, painting, liturgy, music and performance. Cf. Richard Kearney and Matthew Clemente, eds., The Art of Anatheism (London: Rowman \& Littlefield, 2018) in which a previous version of Chapter 3 of this book was published.

29 Wuthnow recognizes that world religions host both types of spirituality, but claims that, in times of insecurity and unsettlement, people are forced to negotiate with themselves and others to find the sacred. See Robert Wuthnow, After Heaven. Spirituality in America since the 1950s (Berkeley, CA: University of California Press, 1998), 3-4. 
a particular public ritual - a ritual that in the public sphere has so often been framed as 'a miracle in the secularised Netherlands'. ${ }^{30}$

This study sets off with the seeming paradox that a contemporary multimedia event in the public square, based on the religious narrative of the suffering and death of Jesus Christ in 'the secularised Netherlands' has become so popular. In line with research that has countered a dichotomous thinking in binary oppositions such as religious-secular or religious-cultural, I use the case of The Passion to illustrate how Christian religion in the Netherlands has indeed not disappeared, but has undergone deep transformations. And I suggest that a new quest for God requires an open theological view and open theological concepts. To prevent misunderstandings, I should make clear that I do not simply intend to classify The Passion as religion, or as a religious event: it is a complex phenomenon with a variety of religious and non-religious meanings attached to it. The Passion is a religious phenomenon and, at the same time, it is not. It is a sacred event, and, at the same time, it is not. As will be seen in Chapter 1, many atheists and agnostics attend the event, and it is not just Christians who gather around this musical narrative. I use the example of The Passion to proffer further interpretations and characterisations of the transformation of Christian religion in Dutch society. The Passion, in this book, functions as a pars pro toto for broader reconfigurations of the religious landscape in the Netherlands. Similarly, my re-interpretations of The Passion as not only a ritual performance, but also as a quest for God, suggest how new outlooks on where and how God can happen anew could take shape and may lead to discover traces of God in contemporary culture.

Although this monograph is based on one Dutch case, the narrative of this book exceeds the religious activities of a tiny country in north western Europe: it also shows how cultural dimensions deeply transform religious forms. In doing so, it does not depart from religion as a fixed and well-defined phenomenon, in fact, religion can be defined in very many ways and scholars continue to wrestle with the term. ${ }^{31}$ Rather, this book understands 'religion' in an

30 I have considered to write God as 'God' throughout this book because the word/name has no fixed content. However, I have decided to omit them, because I presumed that the constant use of inverted commas would be an obstacle to the reader. Another reason is that without inverted commas the word God is already a metaphor: it is a name for we-do-not-exactly-know-who-or-what. The difference between God, god, the divine, the $\mathrm{O} /$ other, the S/stranger, the sacred and the religious should not be trimmed with all kinds of distinctions or even oppositions, but relativised: I take are all these as open notions that are and may be filled with meaning in various ways.

31 See Brent Nongbri, Before Religion. A history of a modern concept (New Haven: Yale University Press, 2013) for an elaborate discussion of notions of religion. 
open, dynamic and situational manner. As anthropologist Martin Stringer has argued, religion is not a distinct and coherent 'thing', nor is it "essentially an intellectual activity". ${ }^{32}$ It is not a set of dogmas and values to be swallowed or affirmed - this is a fixed and one-sided view of the phenomenon. Stringer suggests that "the definitions [of religion, $\mathrm{MK}$ ] that have developed (...) "have been heavily dependent on certain preconceptions within a series of Western discourses that are essentially underpinned by Protestant Christianity". ${ }^{33}$ Much like Stringer in his study, I do no enter my study with a pre-established understanding of religion. Going out to 'the other', as scholars using ethnographic research methods do, I want to understand deep transformations that are occurring, whether or not these are eventually defined as 'religion', drawing on empirical studies of ordinary people and parties engaged in a ritual based on a Christian narrative. 'Ritual' here is used as an anthropological term denoting "the performance of more or less invariant sequences of formal acts and utterances not entirely coded by the performers". ${ }^{34}$ The 'sacred', a concept that will also be discussed in various chapters, in this book is generally taken as the things and events that are set apart, either physically or mentally (in processes of meaning-making), either religious or secular (in the sense of: not having any reference to the transcendent). ${ }^{35}$

\section{The Place of the Case in This Book}

After initially embarking upon empirical investigation of contemporary passion performances in Dutch culture in 2010, in early 2011 I began also to engage in fieldwork on The Passion, during the very first edition of the event. At the time I had no idea that The Passion would become so big, either in terms of media attention or viewers, nor had I expected that this one-off study would subsequently result in longitudinal empirical research. Since The Passion proceeded to develop into an annual event and, over time, developed as a recognised phenomenon in the Dutch public sphere (and moreover: proved

32 Martin D. Stringer, Contemporary Western Ethnography and the Definition of Religion (London/New York: Continuum, 2008), 1-2.

33 Stringer, Contemporary Western Ethnography, 5. The stubborn image of the Netherlands as highly secularised, which is so chewed over in the media, actually should be no surprise, as the idea clearly has a longer history in Western thinking about religion. Roy Rappaport, Ritual and Religion in the Making of Humanity (Cambridge: Cambridge University Press, 1999), 24.

35 This working definition mainly combines the approaches of Gordon Lynch and Lieke Wijnia, see Chapter 4 for the discussion and references. 
to be a very rich case), I decided to make it the central point of focus for this book that I characterise as an 'ethno-case study'.36

Using The Passion to demonstrate how people in our late-modern network society deal with the sacred, this book has a two-fold aim: to contribute to a deeper understanding of the transformation of Christian religion after the devastating impact of the decline of religious institutions in contemporary late-modern Western Europe. And, by extension, to further the development of new ways to speak about God after God. I have thus formulated the following central research question: How is Christian ritual repertoire being transferred, transformed and reconstructed in Dutch late-modern society and where to find traces of God in this newly appropriated ritual repertoire? In my playing with this explorative question, The Passion will serve as a case. In describing and analysing a particular religious trajectory within the network society, I elaborate how conceptions of religion are re-invented, how theology is reconstructed and where traces of God may be discovered in our network culture. I do this through investigation of The Passion, focussing in on practices, discourses, narratives, values and lines of thought.

This has two implications for this book. Firstly, the book is not a handbook on the case of The Passion and, secondly, it does not pretend to offer a complete view of how Christian religion 'works' (or does not work) in the 21st century. I offer an ethno-case study in order to contribute to the academic study of religion and theology. The misunderstanding that one cannot generalize from the study of one case was refuted by Bent Flyvbjerg in an important article in which he states that the case study is in fact a reliable method that contributes to scientific development. ${ }^{37}$ Because of its closeness "to reallife situations and its multiple wealth of details, [the case study] is important for the development of a nuanced view of reality". ${ }^{38}$ Elaborating the ways in which case studies played a crucial role in the development of theories by famous scholars such as Newton, Einstein, Darwin, Marx and Freud, Flyvbjerg convincingly argues: "One can often generalize on the basis of a single case,

36 The term 'ethno-case study' was coined by Marie Parker-Jenkins in 2018 to refer to a hybrid form of research: "an inquiry concerning people, which employs techniques associated with long-term and intensive ethnography, but which is limited in terms of scope and time spent in the field". Marie Parker-Jenkins, "Problematising ethnography and case study: reflections on using ethnographic techniques and researcher positioning", Ethnography and Education 13, no. 1 (2018), 18-33, here 24. DOI: 10.1080/17457823.2016.1253028. More on this term and the research methodology of this study in Appendix 1.

37 Bent Flyvbjerg, "Five Misunderstandings About Case-Study Research", Qualitative Inquiry 12, no. 2 (2006), 219-245.

38 Bent Flyvbjerg, "Five Misunderstandings", 223. 
and the case study may be central to the scientific development via generalisation as supplement or alternative to other methods. But formal generalisation is overvalued as a source of scientific development, whereas 'the force of example' is underestimated". ${ }^{39}$ Eileen Campbell-Reed, in discussing one of the conundrums in practical theology, points to the power and danger that lies in the writing of a single case study: it involves both creating and discovering narratives and ways of analysis. Useful cases are those in which practical theologians use a wide range of methodological tools, she says, and "attend to uses, misuses and possible abuses of power within the situations under study, including their own social location and personal interests in the case". ${ }^{40}$ In line with Flyvbjerg's argument, she restates the value of case studies for practical theology as follows: "A search in the scholarship of practical theology for universal, predictive theories is in vain. The most valuable knowledge is the context-dependent knowledge found on concrete cases". 41

This touches on epistemological questions: what counts as knowledge? What is theory? I find myself at home with the epistemological stance of religious scholar Thomas Tweed, who claims that theory is "purposeful wandering" and "embodied travel". ${ }^{42}$ Theorists "lean on "staffs" bestowed by others as they set out in one direction on a journey of uncertain duration toward sites unseen and vaguely imagined, and they negotiate the trail by what illumination they can find along the way". ${ }^{33}$ And, as Barnard et al. have convincingly demonstrated in their ground-breaking book on liturgical ritual in the network society, knowledge is always "a specific perspective on a particular phenomenon. (...) There is no definitive knowable truth about liturgical ritual, nor of any other phenomenon in this world; there are many perspectives. (...) Knowledge is always transitional in nature, moving between different terms". ${ }^{44}$ This particular view on theory-construction relates to a specific cross-disciplinary model: a transversal approach to interdisciplinary work.

39 Bent Flyvbjerg, "Five Misunderstandings", 228.

40 Eileen Campbell-Reed, "The power and danger of a single case study in practical theological research", in Conundrums in Practical Theology, Theology in Practice 2, eds. Joyce Ann Mercer and Bonnie Miller- McLemore (Leiden/Boston: Brill, 2016), 33-59, here 34. I addressed these issues in the methodological account in Appendix 1, where I elaborate on my own particularity as a researcher.

41 Campbell-Reed, "The power and danger", 47.

42 Thomas A. Tweed, Crossing and Dwelling. A Theory of Religion (Cambridge, MA: Harvard University Press, 2006), 11-13. More on Tweeds theory in Chapter 2.

43 Tweed, Crossing and Dwelling, 13.

44 Marcel Barnard, Johan Cilliers and Cas Wepener, Worship in the Network Culture: Liturgical Ritual Studies: Fields and Methods, Concepts and Metaphors, Liturgia Condenda 28 (Leuven: Peeters, 2014), 6-7. 
According to Richard Osmer, this approach "pictures the relationship of the disciplines as an interacting network of different fields", a specific dialogue between researchers from different fields generates new and particular knowledge where values and perspectives intersect. ${ }^{45}$ I take a transversal approach of cross-disciplinary dialogue because it acknowledges a late-modern view on contemporary Western late-modern culture that is characterised to a high degree both by pluralisation and by fluidity of boundaries. Each interpretation is one among an endless possible number of interpretations of a limited practice. ${ }^{46}$ As a result, in the subsequent chapters of this book, I offer theories that are au fond dynamic. The narrative, perspectives and theories I present, are self-evidently not the only possible narrative, perspectives and theories. Yet, they do shed light on some significant aspects of the transformation of religion in our late-modern culture, and on how this affects the practical theological discipline. The transformation of religious forms and the emergence of new quests for God in a late-modern, liquid society (see Chapters 2 and 3) entail the need for open, updated and sometimes new concepts, metaphors and methodological approaches. Just as I understand 'religion' in an open, dynamic and situational manner, therefore, I also understand practical theology as an open, dynamic and situational discipline - a discipline that is perceived and defined in various ways, depending, among other things, on the perspective of the researcher and the context or situation in which the discipline is practiced (see Chapter 8).

\section{Metaphors and the Structure of the Book}

The Passion is a public event, a ritual-musical play. This has led me to choose metaphors related to play, plays and theatre (e.g. lighting terms), in structuring the book. The metaphor of a play underlines the conviction that what I stage in this book is only one of many possible narratives - it is one, contextual and situational interpretation of how religion has changed in the Netherlands, and of how a public ritual practice can be read as a new quest for God. This Prologue functions as an introduction: a program, making clear what the book is about and what type of play will be presented to the reader. The eight chapters following this introduction are staged in three parts.

45 On transversality see Richard R. Osmer, Practical Theology, An introduction (Grand Rapids: Eerdmans, 2008), 170-172.

46 Cf. Barnard, Cilliers and Wepener, Worship in the Network Culture. 
In Part 1, I present and introduce the basic claims of this book: that religion in network societies is a complex matter; that, in this complexity, the quest to think God afresh is a key concern; and that this quest requires concepts and language that enable us to theologise beyond the normativity of institutionalised religion. I will introduce the case of The Passion in detail (in Chapter 1), sketch the dynamic and changing religious landscape that forms the scenery against which this play is performed (in Chapter 2), and show how in this public ritual God may 're-appear' on the scene in a new form (in Chapter 3). I thus set the stage for the middle part of the book.

In Part 2, various chapters shed light on these matters from perspectives related to different disciplines. As I have already highlighted, these perspectives are not exhaustive - many more viewpoints are possible and would definitely yield more and different knowledge - but they present at least a number of crucial elements and aspects of how religion moves around in contemporary culture. These 'cross-fading perspectives' on The Passion thus unveil several qualities found in practices of Christian ritual repertoire in the contemporary world.

Chapter 4 focuses on The Passion as a spatial practice. Although many atheists would like to see religion safely hidden behind the front doors of people's houses, religion is often reinvented in the public sphere: it is a collective spatial practice. Within the public sphere, parties other than the institutionalised church seem to have taken the 'traditional' place of the church in shaping a ritual practice that has Christian roots. When broadcasting companies and their partners stage The Passion in the public square, we see religion taking the form of a multidimensional spatial practice that is often also a contested practice: different people and different parties appropriate the common ground differently, and (religious) conflicts are never far away.

In Chapter 5 , a digital media perspective shows that religion has increasingly become a playful phenomenon that includes all kinds of digital technologies. Demonstrating how multimediality, virtuality, interactivity and connectivity come into play in the performance of a multimedia passion event, we here describe the phenomenon as a ludic practice, linking contemporary ritual practice with a global ludification of culture and the anthropological stance of homo ludens.

Chapter 6 points to the reflective quality of public ritual events that have Christian roots. This becomes clear when we demonstrate how The Passion engenders public reflexivity in Dutch society: it serves as a mirror reflecting contemporary religious and moral debates, for instance on the supposedly secular nature of Dutch national identity and on the rise of Islamophobia. 
Chapter 7 describes the theological quality of public ritual events. In rituals based on Christian religious narratives that are broadcast and even shaped by the media, theology is constructed. Although the practice of theology is not limited to academia - the activities of believers and of religious leaders, among other things, are considered as forms of practical theology as well theology in liquid societies is not only performed by scholars and/or clergy and/or believers, but has become a practice undertaken by various and different practitioners whose core business is not theologising, but something else. This chapter sheds light on how the body of broadcasting companies and TV producers and channel coordinators engage in public theology in their own right and manners.

The respective chapters in Part 2 are followed by Side lights, in which I theologically reflect on issues that loosely relate to one or more topics in the preceding chapters. These deserve a brief explanation and further characterisation here.

The Side Lights are a kind of 'free play': rather than a critical scholarly treatise, in these creative interruptions I offer theological reflection in a different style. Each reflection is written in a different (theological) genre (a meditation, a Twitter thread, a meditative exegesis, and a letter), often bringing in a mix of Biblical sources, imagination and engagement. ${ }^{47}$

Academic research sometimes takes creative forms. Research in the creative and performing arts, although still not uncontested, has acquired a place in academia in the past two decades: art practices and products are considered to embody a unique type of knowledge. Artistic research can be seen as a form of knowledge production. This type of knowledge may be less conventional than scholarly knowledge, but is an epistemological resource nonetheless, according to professor of theory of research in the arts, Henk Borgdorff. ${ }^{48} \mathrm{He}$ claims that "Art practice - both the art object and the creative process - embodies situated, tacit knowledge that can be revealed and articulated by means

47 As Ellen Davis and Richard Hays have rightly claimed, "reading Scripture is an art - a creative discipline that requires engagement and imagination, [...] Like every other form of art, reading Scripture has the potential for creating something beautiful. Interpretations of Scripture are not just right and wrong, although at times such categories are useful and necessary". Ellen Davis and Richard Hays, eds., The Art of Reading Scripture (Grand Rapids, MI: Eerdmans, 2003), xv-xvi (emphasis in the original text). Also see Paul Ballard, "The Use of Scripture" in The Wiley Blackwell Companion to Practical Theology, ed. Bonnie Miller-McLemore (Oxford: Wiley-Blackwell, 2012), 163-172.

48 See Henk Borgdorff, The Conflict of the Faculties: Perspectives on Artistic Research and Academia. (Leiden: Leiden University Press 2012), 17. 
of experimentation and interpretation" ${ }^{49}$ Borgdorff concludes that research in the arts and research of the arts are of equal value. ${ }^{50}$

In practical theology too, creativity and imagination have a place. Richard Osmer has described the work of a practical theologian as the work of an artist in his/her artist's studio, pulling together insights that have evolved from examinations; a practice that requires creativity and imagination. ${ }^{51}$ Marcel Barnard, Johan Cilliers and Cas Wepener et al. have epistemologically described the investigation of liturgical ritual as splattering or laying out dots on a blank sheet. They conclude that a non-discursive and non-conceptual approach of research in the arts may advance the understanding of the liturgical ritual. ${ }^{52}$ Other practical theologians have taken the notion of creativity even further: Courtney Goto teaches her students to reflect theologically by creating art in her course 'Doing Theological Aesthetically', offering them a way to experience that aesthetic sensibilities are also part of theological construction, which involves processes of knowing and reflecting - not just in words, text, language. ${ }^{53}$ Heather Walton, among others, has performed practical theology in the shape of creative writing, thus seeking how pastoral poetics can yield knowledge by means of, or rather: in the form of, deep metaphoric and reflexive writing. By doing so, she aims to open new horizons for the discipline of practical theology. Poetics, according to Walton, has the potential to change our understanding of Christian practices. This understanding is the result of "practical theology's quest to name God as the one who calls us to incarnate a witness to passion and resurrection in the poetry of our practice". 54

In line with these developments in academia and in practical theology, I offer a different type of theological reflection in the four Side Lights in Part 2: playful, creative, self-reflective (and partially essay-ish) texts that intend to evoke thoughts rather than prove a point. Since they are part of a scholarly monograph, but also because these reflections are theological practices in their own right, I consider them as academic practical theological texts of their

49 Borgdorff, The Conflict of the Faculties, 53.

$50 \quad$ Borgdorff, The Conflict of the Faculties, 17.

$5^{1} \quad$ Richard Osmer, The Teaching Ministry of Congregations. (Louisville: Westminster John Knox Press 2005), 197ff.

52 Barnard, Cilliers and Wepener, Worship in the Network Culture, 59.

53 Courtney Goto, "Reflecting Theologically by Creating Art: Giving Form to More than We Can Say", Reflective Practice: Formation and Supervision in Ministry 36 (2016), 78-92. See http://journals.sfu.ca/rpfs/index.php/rpfs/article/view/426/413.

54 See e.g. Heather Walton, "Poetics", The Wiley-Blackwell Companion, ed. MillerMcLemore, 173-182, 181. 
own kind, hoping that the 'space' between the chapters in Part 2 and these respective reflections may help to see more clearly what could be going on in terms of a new quest for God. ${ }^{55}$

Finally, Part 3, by way of 'Full-up finish', ties together what has been presented in Parts 1 and 2. In Chapter 8, I reflect on the path of religion through society, addressing the question of what the interplay of transfer, transformations and theological reconstructions in Dutch late-modern society after the death of God means for the practice of Practical Theology. Similar to how lighting operators bring all relevant dimmers to full for the finale of a show, I highlight my view on the implications of what I have staged in the preceding chapters for the discipline of Practical Theology, relating this study to broader developments and conundrums in the field. With this, I walk off the stage and leave the spectator to ruminate, and the reader to ponder.

Appendix 1 offers an account of the research methodology underlying this book. I chose to first tell the story and afterwards account for the research process and methods, but any reader who wishes to do so, can start their reading with this methodological account. Appendix 2 contains tables with quantitative research data on the viewers of The Passion that support the account of Chapter 1. Throughout this book, Bible verses and quotes are taken from the English Bible translation New Revised Standard Version (NRSv), unless otherwise specified.

\section{Authorship}

Before I enter the stage with my narrative, a few words on authorship. In several chapters of this manuscript, I have presented colleagues (theologians with different specialisations, in practical theology and/or systematic theology, sociologists of religion, and religious studies scholars) as co-authors. Over the past couple of years, I have published a number of co-authored articles, parts of which were used in and amended for this book. Each chapter contains a footnote indicating which co-author contributed in what way, and in which previous publication. So, although I designed and executed this research project, although I wrote this monograph, and although the cover has

55 In Chapter 8, I further elaborate on the character of these side lights in the context of doing practical theology in times 'after God'. Suffice it to say here that identifying God for others, e.g. for those to whom traces of God are not real or do not matter, is not my aim. 
my name on it, the book contains portions of texts that were initially written by others. My co-authors have all allowed me to adapt the text and take up the thread of our narratives again. The use of first-person pronouns in this book therefore reflects the contributions of different authors: first-person single pronouns refer to myself, whilst in co-authored chapters first-person plural pronouns refer to myself and the authors whose names are mentioned under the titles of the respective chapters. The idea and composition of the entire narrative of this monograph is mine and is entirely new.

\section{Positionality Statement}

As a practical theologian, trained in various theological sub-disciplines and specialising in liturgical and ritual studies, I have always had a particular interest in music. I was raised in a Lutheran family, which profoundly shaped my faith and theology, and have been actively involved in making (classical) music since the age of seven. I am intrigued by the dynamics of cult and culture, and I find myself sliding back and forth between being orthodox and rather 'churchy' and looking at the church and Christian religion somewhat critically and from a distance. As an ordained minister in the Protestant Church in the Netherlands, I understand and am aware of the challenges that those responsible for liturgy in the church face in the late-modern Western world. I thought and still think that in a network society, it is as realistic as it is necessary to acknowledge that theologians and churches can learn from people and parties in the broader cultural domain and the ways in which they appropriate and transform music and rituals that are part of Christian heritage. This conviction has a normative element to it too, and one that is theologically informed: it turns out I have a weakness for (those engaging in) practices that are frowned upon, condemned, or bashed, by people who are all too convinced that they are right. People who know all too well how God wants things to be, and what is theologically right (even if Sachkritik and ritual criticism are part of the game) often make me suspicious. This normativity does not make me an advocate of practices such as The Passion, of course (although I have been depicted in the media as a supporter of The Passion a number of times, because of my research on the topic); it is just that people and practices that are looked down on simply spark my interest and are reason for investigation. I value these practices in the broader cultural domain as part of a new quest for God - even when those engaging in them do not explicitly frame them as such, or wonder aloud whether God actually exists. What helped in this respect is the fact that I myself have also not been entirely unfamiliar with 
feelings of god-forsakenness, the desire to turn my back on God, and at times even the conviction that there is no God at all. But every inch a theologian, I always end up trying to find traces of God in the world we inhabit. This research is an effort to arrive at a better understanding and deeper knowledge of how contemporary appropriations and transformations of religion work and where, in all this, traces of God might be found. This requires an open mind; not uncritical, but primarily aimed at understanding how in our 21st century society Christian religion changes and how we can imagine God pitching tent with people in their particular times and places.

Now, let the play begin. 
Mirella Klomp - 978-90-04-44294-8 Downloaded from Brill.com04/26/2023 09:16:19AM via free access 
PART 1

\section{Setting the Stage}

The first part of this book can be read as a broad discussion of how the Dutch religious landscape has changed, how this relates to transformations of (Christian) religion within the complexity of network societies, and how, in this complexity, the quest to think God afresh is constantly close at hand. Chapter 1 introduces the case of The Passion in detail, as a play, and shows what the transformation of a public ritual with Christian roots may look like within a liquid culture. Chapter 2 sketches the dynamic and changing religious landscape against which this play is performed. Chapter 3 shows how in this public ritual God may 're-appear' on the scene in a new form. 
Mirella Klomp - 978-90-04-44294-8 Downloaded from Brill.com04/26/2023 09:16:19AM via free access 


\section{The Play: A Popular Passion in the Public Sphere}

It is 8:30 PM on Maundy Thursday, three days before Easter. Welcome to Gouda! (...) Tonight, Gouda forms the stage for The Passion: the story of Jesus Christ's last hours, communicated through images, words and well-known Dutch pop songs (...) The Sacred united with worldly music in a way the Netherlands has never seen or heard before. It is a story of sacrifice, forgiveness, of hope. But also a story of love so powerful that throughout the world, millions of people have talked it about across the ages. And, as the most read book in the world states: God did not send his son Jesus to judge people, but to save them. So: let us go with him.

NARRATOR 'JAKHALS ERIK', 21 April 2011

(Market square, Gouda)

With these opening sentences, on Maundy Thursday 2011, the narrator introduced The Passion to nearly 20,000 people gathered in the market square in front of him, to around one million viewers who watched the live broadcast of this remarkable performance on the third Dutch national public TV channel, and to Dutch society. A new, large-scale musical event performed in the market square of a Dutch city, comprising a popular retelling of the passion story. The scene for the action was Gouda, a city of some 100,00o inhabitants, situated close to the urban agglomeration of Western Holland, and part of the Dutch Bible belt (a strip of land in the Netherlands where many Christians are conservative Protestants). A TV producer organised the event in cooperation with two Christian broadcasting companies from the Dutch public broadcasting system, with the Netherlands' two largest churches, and with the municipality of Gouda. It was broadcast live on NPO3, the third channel on national TV which is aimed particularly at the youth demographic. The main stage for the performance was built on the Market in the city centre, in front of the historic and monumental Sint Janskerk. A helicopter circled overhead, to film shots for the live TV show. Some of the country's most famous pop stars and actors played the parts of biblical characters such as Jesus, his mother Mary, and Judas. A Dutch reporter, well known for his appearance on a daily Dutch 
prime time Tv talk show, to many people's surprise, played the part of the narrator and told the story with great fervour. He said that he was very proud to have been allocated this role, although he was "not a faithful Christian, and was raised non-religious". ${ }^{1}$

At the time of the original performance, no one expected The Passion to become such a 'successful' event in Dutch society. Over the years, it has become a public ritual and, at the same time, a popular live TV show with annual editions that continue to gain a lot of attention. ${ }^{2}$ The event has drawn an increasing number of people to the city squares where it is staged and participation in the procession with a large neon lit cross, which is part of the ritual, has become increasingly popular. After the success of the first edition, the broadcast in 2012 was moved from the third to the first Dutch TV channel (from NPO3 to NPO1). The TV viewing figures over the years show a gradual development. ${ }^{3}$

Media (national newspapers, prime time daily radio and $\mathrm{TV}$ shows of public as well as commercial broadcasting, etcetera) have come to pay attention to the event on an annual basis. As the phenomenon had grown, it has come to increasing prominence and, as a result, has come to be considered for potential export. The Dutch producer offered to share the format with a famous producer in the USA, ${ }^{4}$ and, together, they staged The Passion Live in New Orleans on 20 March 2016. It was aired by broadcasting company FOX and, after a few days, was made available worldwide via streaming service Netflix. In Bel-

1 Erik Dijkstra, promotional interview by broadcasting company E0, some weeks before the performance of The Passion in Gouda. See: "Jakhals Erik over The Passion", Evangelische Omroep, April 13, 2011, YouTube. https://www.youtube.com/watch?v=x7 GdgfcV7JY. Last accessed May 10, 2020.

2 All editions of The Passion performed so far are online available. See: "The Passion", NPOStart, Nederlandse Publieke Omroep, last accessed October 1, 2019, https://www.npostart.nl/the -passion/VPWON_1289791.

3 The slight decrease in viewers in 2016 was probably directly related to the fact that broadcast of The Passion had to compete with an extra broadcast on the other national channel because of the death of world-famous Dutch soccer player Johan Cruijff, earlier that day. There was no clear explanation for the dropping number of viewers in 2019 (perhaps the Europe League soccer match that the other national channel broadcast at the same time, however, that would not explain why the viewing share is still high). Source: PDF-document created by Petra Moonen, market researcher at broadcasting company KRO-NCRV, obtained on 6 June 2017, and two emails by her containing additional figures on the 2018 and 2019 edition, received on 20 August 2018 and 26 August 2019. 'Share of viewing' is 'the percentage of the total viewing audience watching over a given period of time', see: "Share of viewing". Glossary of Commonly Used Industry Terms, BARB. http://www.barb.co.uk/resources/barb -facts/glossary?_s=4. Last accessed May 10, 2020.

4 The co-producer was Adam Anders, a Swedish film, television and music producer working in the USA. 


\begin{tabular}{llcc}
\hline Year & City & $\begin{array}{c}\text { Absolute number of } \\
\text { viewers incl. delayed } \\
\text { viewing } \times \text { 1000 }\end{array}$ & $\begin{array}{c}\text { Viewing share among } \\
\text { people above the } \\
\text { age of } 6\end{array}$ \\
\hline 2011 & Gouda & 1.032 & $17.4 \%$ \\
2012 & Rotterdam & 1.866 & $24.9 \%$ \\
2013 & Den Haag & 2.512 & $32 \%$ \\
2014 & Groningen & 3.558 & $43.8 \%$ \\
2015 & Enschede & 3.851 & $46.2 \%$ \\
2016 & Amersfoort & 3.417 & $44.4 \%$ \\
2017 & Leeuwarden & 3.316 & $43.7 \%$ \\
2018 & Amsterdam & 3.539 & $45.4 \%$ \\
2019 & Dordrecht & 2.662 & $40.3 \%$ \\
\hline
\end{tabular}

FIGURE 1 Viewing figures of The Passion for respective editions

The edition in Roermond in $202 \mathrm{O}$ was cancelled a week before the date of the performance, due to government measures aimed at preventing the further spread of the Covidig-virus. Instead, an alternative version was created: in a live broadcast from the 'Media Park' in the city of Hilversum (also known as 'the heart of the Netherlands' media industry') on the evening of Maundy Thursday, a narrator presented the Passion narrative and this was alternated with videoclips taken from earlier editions of The Passion.

gium, three editions of The Passion were performed in three different cities (in 2014, 2016, and 2018). ${ }^{5}$

This chapter describes the case of The Passion in detail. The case draws in a number of themes relating to the change of religion in late-modern societies, and the subsequent chapters in this book will present a number of perspectives on what these changes actually entail. However, this requires, first of all, a detailed account of the particular shape of The Passion itself.

\section{Initiative and Development}

The original initiator of The Passion project was Jacco Doornbos, founder and CEO of TV production company Eye2EyeMedia. ${ }^{6}$ Doornbos took his initial in-

5 As in the Netherlands, the 2020 performance in Belgium, as well as the first German edition, which was to take place in the city of Essen, were cancelled due to the Covidig-outbreak.

6 Although Doornbos' company Eye2EyeMedia continued with three other partners as a new company with the name 'Mediawater' on January 1, 2019, I refer to Eye2EyeMedia in this 


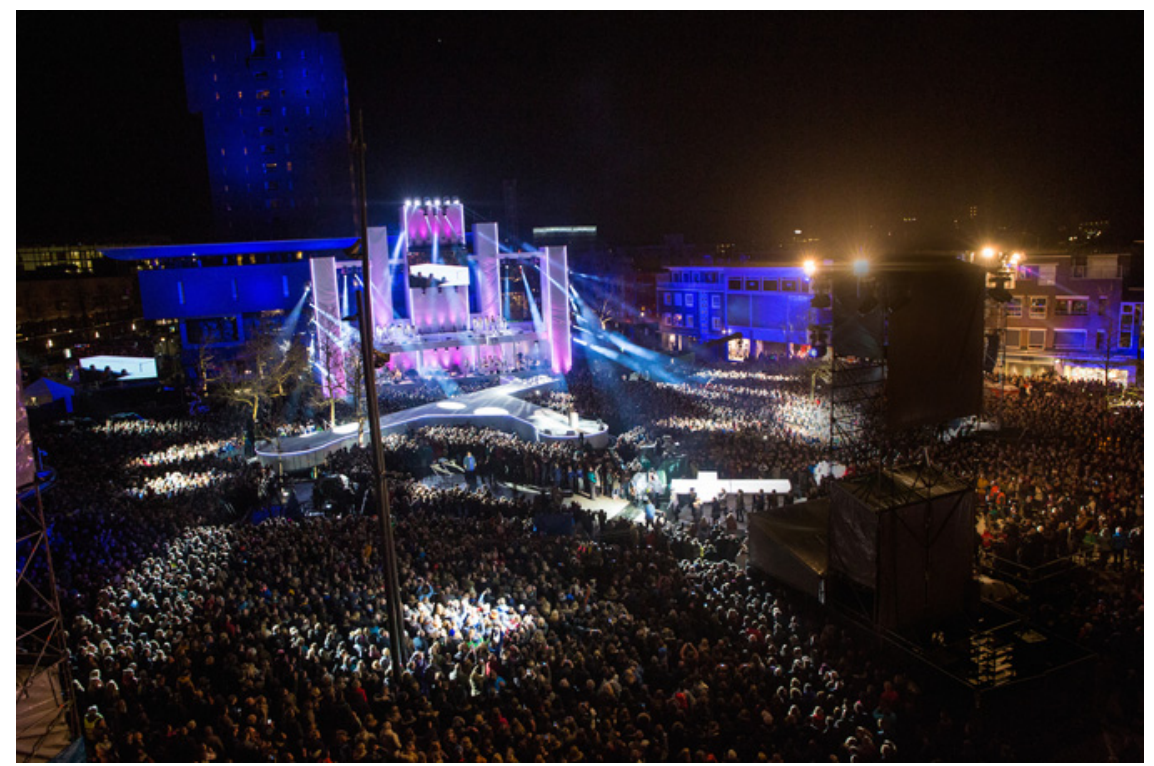

FIGURE 2 The H.J. Van Heek Square in Enschede where the main stage for The Passion was erected in 2015

PHOTO: MICHAËL TERLOUW

spiration from the Manchester Passion - a passion play performed as a one-off event against the backdrop of the contemporary music of Manchester (UK), performed in that city on Good Friday (14 April 2006) and broadcast live on Вв $3 .{ }^{7}$ Specialising in the production of $\mathrm{TV}$ programs that aim to communicate "positive values to a broad audience in a creative, attractive and accessible manner" and to translate "seemingly difficult or unpopular but always relevant or important subjects into attractive, accessible and successful communication applications", ${ }^{8}$ Doornbos' small company picked up the format and, together with the broadcasting companies, further developed it.

manuscript, as this corporate entity was responsible for eight out of the nine editions that The Passion has seen so far.

7 See ввс, "Heaven knows it's Manchester now", Last updated April 13, 2006, https://bbc.in/ 2MrmQ2V. Last accessed May 10, 2020, and view online on "The Manchester Passion 2006", Eddie Pearson, streamed on May 2, 2011, YouTube-video, 59:52, https://www.youtube.com/ watch?v=UAfLCV9ZeZY. Last accessed May 10, 2020. The Manchester Passion was used as a case in an article by Elaine Graham, "What We Make of the World. The turn to 'Culture' in Theology and the Study of Religion", in Between Sacred and Profane: Researching Religion and Popular Culture, ed. Gordon Lynch (London: I.B. Tauris, 2007), 63-81.

8 "Aim", EyezEye Media, http://www.eyezeyemedia.nl/index.php?option=com_content\&view $=$ article\&id=73\&Itemid=101\&lang=en. Last accessed January $25,2016$. 
In his hunt for cooperation partners, in the years leading up to 2011, Doornbos attempted to bring The Passion together with 'neutral' participants, to stay away from the image of a 'missionary' event: "I wanted to bring this narrative in an unsuspected way. To avoid that people would get the feeling of being preached upon, or be the subject of winning souls and making disciples". ${ }^{9}$ In the end, producing The Passion without Christian broadcasters turned out to be an idea hard that was to sell in the Dutch broadcasting system. Eye2Eye Media eventually found partners in two Christian broadcasting companies: RKK (broadcaster on behalf of the Roman-Catholic Church) and evangelical broadcaster EO. Both partners had their own motives for engaging in the production of the event. These were related to their mission statements: Eo has always aimed to 'shape and pass on the Kingdom of God' (EO), whilst RKK aims to 'bring the gospel to the street'. After RKK had merged into the larger broadcasting company KRO-NCRV in 2016, this broadcaster formulated their motivation in slightly broader terms: "Our goal is not an event with a strong missional message. It is just a narrative we want to pass on. We do not aim to evangelize people - that is their own business. It is meant to make people think, and it must be informative, like 'Okay, so in our history this has been an important narrative". ${ }^{10}$

Having brought onboard the involvement of Christian broadcasting companies, engagement with both protestant and roman-catholic parties was crucial to Eye2EyeMedia, in order to prevent any single group from 'claiming' The Passion. Together, the producer and broadcasting companies took the lead in the organisation of the event, both in terms of practical presentation and mediation, but also of form and content. With the Dutch Bible Society (NBG), the Protestant Church in the Netherlands (PKN), and initially also the Roman-Catholic Church and the Belgian Roman-Catholic broadcasting company Braambos, they started to prepare the first performance that took place on Maundy Thursday (21 April) 2011, at 8.30 PM.

Staging the first performance involved taking on an element of risk: how would such a musical re-telling of the Christian passion narrative be received in a society that had seen such a strong decline in church membership, and in which the voice of the church in the public sphere had become so marginal

9 Jacco Doornbos, interview by $\mathrm{MK}$, September 17, 2015.

10 Sources: general aim EO, see "Missie Evangelische Omroep", Evangelische Omroep. https://portal.eo.nl/over-de-eo/missie-en-bestuur/missie/. Last accessed May 10, 2020. Aim of RKK coming from interview by M K with Leo Fijen (head of broadcasting company RKK), December 5, 2011. Aim of KRO-NCRV coming from interview by MK with Reinder van Dijk, February 18, 2016. 
over the preceding decades? No one knew. The general reception of the public turned out to lean to the positive side, although there was scepticism as well, also in the media. Shortly after the performance, the makers contemplated a second edition and indeed decided to rerun the performance the next year. This second edition was staged in the city of Rotterdam on 5 April 2012, on Willems square, close to the Erasmus bridge, and was even larger (with new leading stars that were even more famous compared to those of 2011, and more TV viewers). With the performance in Rotterdam which, at the request of the channel coordinator, was this time broadcast on NPO1, the knowledge and popularity of this passion event appeared to expand further. A new annual tradition seemed to have been born: the performance and broadcast of The Passion at prime time on the first Dutch TV channel on the evening of Maundy Thursday. Subsequent editions of The Passion have taken place annually in different cities, between 2012 and 2019 (see Figure 1, above). Each year, between 15,000 and 20,000 people come to the square, and in Groningen the main square was fenced off more than half an hour before the performance started, because the police and security services could not guarantee the safety for more than the 20,000 people that had already gathered. About 1.0 million people watched the first performance in 2011, which was almost one out of every five TV viewers that night. In 2015, the number had gone up, even to the extent that half of all $\mathrm{TV}$ viewers that night watched The Passion. Because of its popularity, the length of the broadcast has been extended over the course of the years: in 2011, the show lasted 70 minutes, in 2016, 9o minutes. The program was the largest live television event in The Netherlands for the years 2011, 2012 and 2013, and won an award for best entertainment program in 2014. ${ }^{11}$ Its annual budget has come to exceed 1 million euros.

Since the first edition, the procession with a large cross that is carried through the streets of the city has been a consistent part of The Passion. The aim of the producer was to give people the opportunity to express their personal appropriation of the event. The role of the 'news reporter' was invented to direct these expressions. ${ }^{12}$ The organizers have continued to struggle with the procession, experimenting, for example, with (pre-)production filming in order to make sure that they would have at least a few good conversations to broadcast, however the procession has become more and more popular for

\footnotetext{
11 The so-called TV Beelden award. Cf. "Winnaars de Tv beelden 2014". De TV Beelden. http:// detvbeelden.nl/winnaars/winnaars-2014/. Last accessed May 10, 2020.

12 Doornbos, interview, September 17, 2015.
} 
sections of the public over the years. ${ }^{13}$ While in Gouda in 2011 the makers had to approach people to make sure they had enough 'cross bearers' and people following in the procession, for Amersfoort in 2016, the registration for the procession, which was opened four months in advance, was booked up in almost no time at all, and all 1,00o places were allocated in less than go minutes. ${ }^{14}$ From 2014 onwards, in addition to the physical procession, a second-screen application was launched for people to virtually walk along using virtual means. In 2014, over 25,000 people joined this virtual procession, in 2015 this number increased more than fivefold, to 135,000, and in 2016 some 145,00o virtually followed the cross. Alongside the second-screen application, the broadcasting companies launched the hashtag \#iwalkalong on Twitter, which created another form of virtual procession. ${ }^{15}$

\section{The Ritual: Fixed Format, Liquid Aspects}

By modelling and moulding the performance and broadcast, the production team actively gives shape to the communication of this religious narrative each year. A fixed format, a number of aspects that can take on different forms, and the unique features which characterise the production give the performance its particular characteristics and contribute to its success.

13 Our analysis of various interviews with organizers made clear that the struggle with the procession basically followed from the difficult combination of different elements. Firstly, walking the procession for participants was a rather serious affair and gradually to many it became a kind of pilgrimage. Along the route they were interviewed by 'news reporters' who were experienced Tv hosts in entertainment shows, but did not always have and/or understand the (religious) language or sensibility to interview them. (E.g. one reporter asked: "Why do you want to suffer?"). These news reporters were deliberately chosen bearing in mind the part of the audience that had no idea of what the passion narrative is about (Doornbos, interview, September 17, 2015). Secondly, in a live show, it is a risk to get members of the public in front of the camera without prior screening. In some editions, prior research led to people with a particular narrative being interviewed, but in a live broadcast of a walking procession, it is extremely difficult to get them in front of the camera at the right moment.

14600 people subscribed online to the procession on November 25, 2015. See "Tickets processie The Passion uitverkocht", http://www.kro-ncrv.nl/inspiratie/nieuws/370-37188 -tickets-processie-the-passion-uitverkocht. Last accessed January 26, 2016.

15 The procession is further discussed in Chapter 3, the virtual aspect of religion in Chapter 5 . 


\section{Format}

The music of the production is based largely on covers of well-known Dutch hit songs famous within national pop-history. These covers - secular songs of which the lyrics generally remain unaltered - are placed within the framework of a passion narrative based on the pericopes on the suffering and crucifixion of Christ in the gospels. ${ }^{16}$ They are performed by (more or less) famous Dutch actors and singers, mostly non-Christians who often also decidedly selfidentify specifically as non-believers. ${ }^{17}$ The performers function as role models who form a bridge between the narrative and society. ${ }^{18}$ Well-known Dutch pop music woven into the passion narrative adds a layer of meaning to these songs. A love song, for example, that is normally interpreted as a song about two lovers, acquires a new meaning when sung by Jesus' friend Peter: now the song is also about love in the amical relationship of two friends. From now on, when people hear this song on the radio, they are reminded of The Passion. This format combines the familiarity of songs with the relative unfamiliarity of the passion narrative, and vice versa, and it prevents The Passion from coming across as totally strange. The Passion is thus a clear example of the transfer and transformation of ritual repertoire.

Transfer. The selection of pop songs to be used in The Passion was carried out by Jan Willem Roodbeen, between 2011-2016. ${ }^{19}$ Roodbeen, a radio announcer in everyday life, worked for the Evangelical Broadcasting Company EO (one of the initiators of The Passion) for a number of years and he is both an engaged Christian and an expert on pop music, making him very much the right person for the job. In selecting repertoire Roodbeen was restricted to songs with lyrics in Dutch, the use of the native language being one of the elements prescribed by the format of the Manchester Passion. In an interview, he mentioned two other parameters that restricted the selection of pop songs:

16 The narrative of the first editions was constructed by Doornbos himself, with (minimal) alterations in later years. He made sure that the texts spoken by the main characters (all actors except the narrator), are literally adopted from the Bible. He considered this crucial because critical Christians could not object against the quotation of the bible in the public sphere. Source: Doornbos, interview, September 17, 2015.

After a few editions, the wordings came to show more variation. In 2017, for example, the production team asked cabaret artist Remco Veldhuis, who would play the role of the narrator, to refresh the narrative and deepen its significance by means of new wording.

17 For instance, narrator Jakhals Erik in 2011 (see note 1), but also Jim de Groot who played the role of Jesus in 2015 (see Chapter 6).

18 Fijen, interview, December 5, 2011.

19 Jan-Willem Roodbeen, conversation with MK, August 30, 2019. From 2017 onwards, the song selection for The Passion was made by the organisers. 
Our collective musical memory is not very big. Radio stations always play the same songs, so eventually this is the repertoire of songs that you end up having to choose from. (...) This also accounts for a major part of the success: they are all familiar songs. From the first note you hear you know: that it is this or that song. It's this recollection and this feeling that is placed in the context of the Easter story. ${ }^{20}$

The selection of pop songs, particularly in the first editions, was made with an awareness of the biblical narrative of the passion on the one hand (the lyrics had to harmonize with the biblical narrative), and Dutch popular music culture on the other (the pop songs had to be well-known and part of the Dutch cultural heritage). The process of transfer thus blended the domain of (secular) popular culture and the domain of religion.

Transformation. The transfer of music between contexts may lead to transformations of the text, of the music or of the way in which the selected songs are performed. As indicated, in The Passion, the lyrics, except for a few details, remain basically unchanged. The main transformation lies in the way the pop songs are performed: they are all covers, i.e., they are not sung by the original artists that people associate with them. Songs get covered all the time in popular music and film and television soundtracks, as well as advertisers, increasingly rely on versions of familiar pop tunes to assist in marketing their narratives and products. ${ }^{21}$ The initiators of The Passion use pop songs in the same way: as a marketing tool, to invite people, especially young people, to become engaged with the biblical narrative. Presumably, the impact of The Passion would have been different had the producers used new pop songs specially written for this particular occasion.

The role played by the artists covering the songs in The Passion is one of the important elements in the performance. The song Zeg me dat het niet zo is, ('Tell me it is not true'), for example, was originally sung by male artist Frank Boeijen, but in 2011 was sung by the female singer Do, who played the role of Mary. The sung was written after the artist heard that his mother-in-law would soon pass away, and in the original version, the lyrics are about a couple that struggles with the news that a female loved one is going to die. ${ }^{22}$ This meaning

20 Jan Willem Roodbeen, responsible for the selection of pop songs in The Passion, interview by Martin Hoondert, February 2012.

21 George Plasketes, Play it again. Cover songs in popular music (Surrey: Ashgate, 2010).

22 "Frank Boeijen - Zeg me dat het niet zo is", Financiële Planning Voor Iedereen, last updated October 7, 2017, https://www.fpvi.nl/uitvaartmuziek/zeg-me-dat-het-niet-zo-is/. Last accessed May 10, 2020. 
is transformed by the context of the passion narrative: with Mary singing it, the loved one who will soon die is now her son, Jesus. The text is altered only at the very end, with the final 'she' (the loved one) becoming 'you' (directed to the son). This, in turn, influences the performance, as singer Do explained:

Mary is a person with an all-encompassing love. (...) That is one element of her character. But she is also a mother, a human being with feelings. I thought about that: how do you express that? I wanted to give Mary a human side, to bring her near (...). ${ }^{23}$

The main element of transformation lies in the performance of the pop songs by artists playing a role in the biblical narrative of the passion. This transformation also involves changes in the keys in which the songs are written and changes to the arrangements for orchestra (originally Zeg me dat het niet zo is had piano accompaniment, in The Passion it was accompanied by strings and an accordion). The instruments and arrangements are adapted to suit the emotional charge of the various episodes in the biblical narrative. ${ }^{24}$

Line-up. Generally, the performance starts with a narrator coming on stage. (Only twice, in the 2016 and the 2018 edition, has a woman taken this role, I will therefore refer to the narrator as 'he'.) He welcomes the audience in front of him as well as the television viewers and introduces the performance, linking the biblical narrative to the contemporary and local performance setting of that night. He closes the first scene by introducing Jesus: "Let us meet him now as he enters the city". Footage recorded some time in advance is then shown, showing the man playing the role of Jesus singing the first cover song. ${ }^{25}$ The other characters, such as Peter, Judas and Mary the mother of Jesus, are introduced by means of brief close-up shots taken at the main sites of interest within the cities. The next scene shows footage of Jesus asking the disciples how they see him (Mark 8:27;29). Peter's remark "You are the Messiah" is then followed by a duet sung by Jesus and Peter. From 2016 onwards, other biblical passages that do not strictly belong to the passion narrative were inserted to further 'develop' the show; a prologue with a text taken from the sermon on the mount (Matthew 5:17) in 2016, a section in the middle of the show focussing on the woman caught in adultery (John 7:53-8:11) in 2017 and one centred on

23 Do (Dominique van Hulst), female singer playing the role of Mary in The Passion, interview by Martin Hoondert, February 2012.

24 Cor Bakker, director and arranger, interview by мк, March 2012.

25 This means that the show should probably be characterised as semi- rather than completely live. 


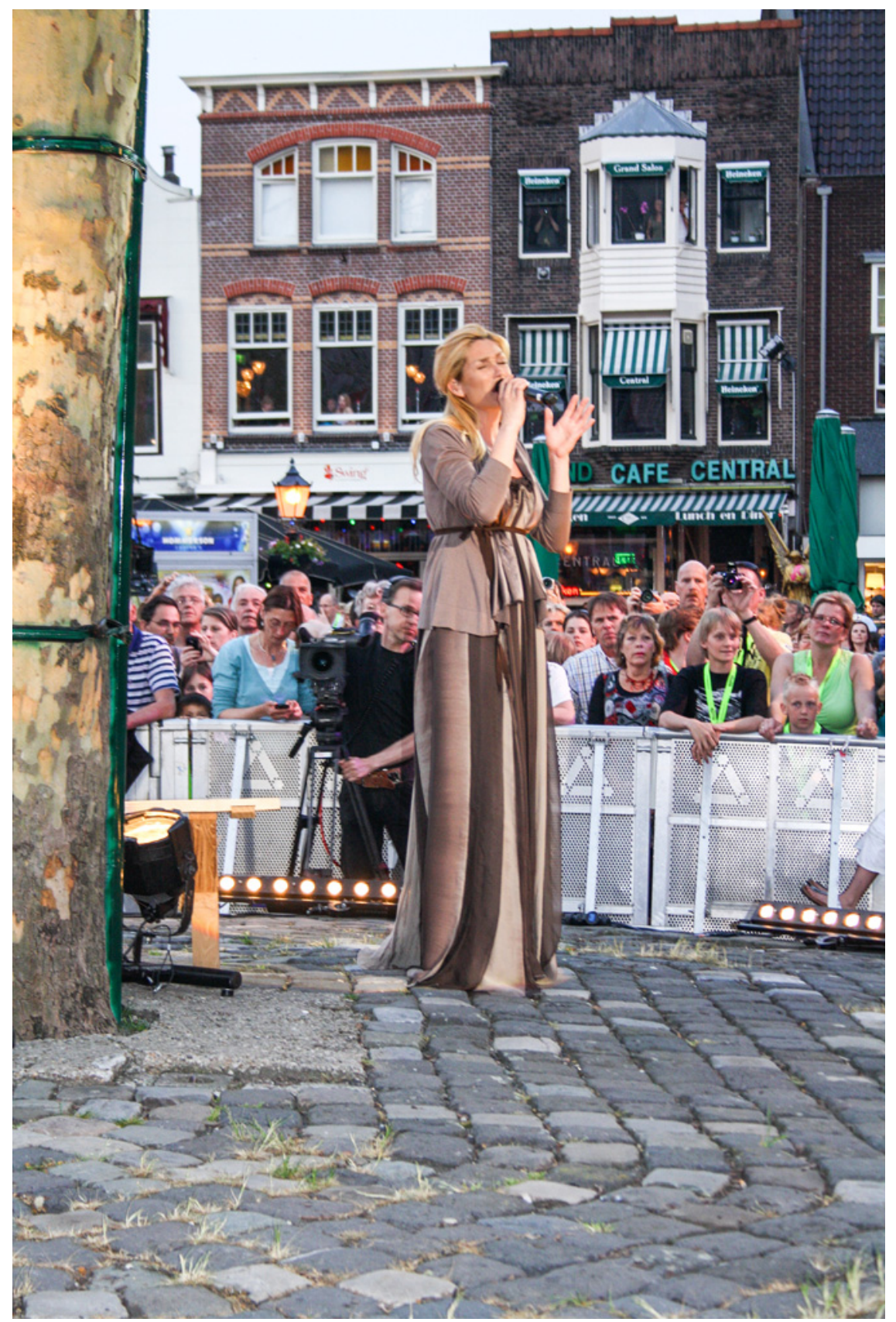

FIGURE 3 Singer Do as Mary, the mother of Jesus. The Passion in Gouda, 2011 PHOTO: (C) HIJME STOFFELS 


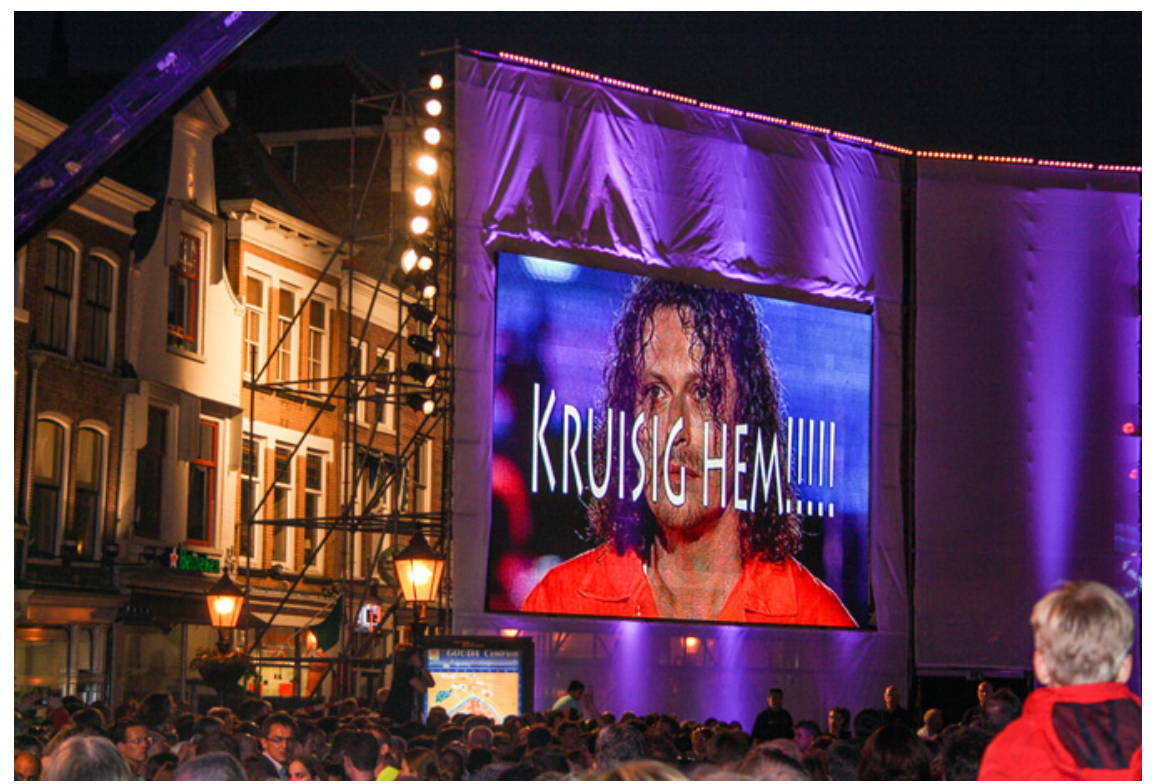

FIGURE 4 The words 'Crucify him!!!!!' over the face of Jesus on the projection screen at the Market Square in Gouda, 2011 PHOTO: (C) HIJME STOFFELS

the woman with a flow of blood (Mark 5:25-34) in 2018. ${ }^{26}$ After this, there is a scene representing the Last Supper. We see Jesus and his disciples preparing the meal, five bread rolls and two little fish are bought, Jesus says the words of institution, and predicts that one of his friends will hand him over: "One of you will betray me". (Mark 14:18; Matthew 26:21; John 13:21). Next, we see the disciples sleeping in the garden of Gethsemane, the arrival of Judas and his betrayal of Jesus with a kiss, followed by the threefold denial of Peter. All pre-recorded footage is projected on large projection screens. Apart from the narrator, Mary, the mother of Jesus, and Pontius Pilate, towards the end of the show, are the only ones on stage. Pilate starts talking about Jesus, meanwhile washing his hands in a bowl of water. The huge projection screens that are put up on the square are now also used to instruct the spectators, to whom Doornbos had allocated the role of the crowd, some fifteen minutes before the start of the performance. Jesus and Barabbas also come on and, at the appropriate time, the audience shouts that they want Barabbas set free, later following this with chants of 'Crucify him! Crucify him!' when these words appear on the screen, flickering in bold capital letters.

26 Van Dijk, interview, February 18, 2016. 
During the show, the narrative intermittently alternates with live coverage of the procession. An actor in the role of a news reporter interviews cross bearers, and the interviewees' personal narratives and their motivations for following the cross, which are often related to personal experiences of suffering, or hope, are thus inserted at different stages of the passion narrative into each performance.

When Jesus is conveyed as a prisoner to be crucified, the procession with the cross approaches the platform. In the first five editions, Pontius Pilate spelled out in detail the various stages of how a crucifixion works, concluding with the observation that suffocation is the cause of death. In the sixth edition, the position of executive producer for EO was taken up by someone with a background in dramaturgy. ${ }^{27}$ She had the scene replaced by a fragment, present in all four gospels, which states that the soldiers hung Jesus on the cross and placed the written charge against him above his head: "This is Jesus, the king of the Jews", that he was mocked and that he was told to save himself and to get down from the cross. ${ }^{28}$ The scene ends with his last words: "Father, into your hands I commit my spirit". One or two songs follow, then the narrator completes the performance and the resurrection (see Chapter 7 ) is portrayed by the Jesus character appearing in white clothes and singing. During the final cover song, all main actors come on stage for the finale, and The Passion is ended with a song.

After the event on the stage has ended and the broadcast is over, several parishes and congregations in the city where it has been staged open up their doors for a so-called 'after Passion', which they have set up in cooperation with the national churches, in some years the local Council of churches, and sometimes also Christian students societies. ${ }^{29}$ Their main goal is to offer a space in which people can share their experiences with others.

\section{Liquid Aspects}

Alongside the fixed elements of the format, the ritual has several elements that change each year in order to make The Passion a flexible and dynamic performance: narrative and music, location, performers, motto and audience. ${ }^{30}$

\footnotetext{
27 Van Dijk, interview, 18 February 2016.

28 Marc 15:26; Matthew 27:37; Luke 23:28 and John 19:19.

29 The 'After Passion' in Gouda for instance consisted of film shots, silence, singing of Taizéchants, prayer and small-scale shows by performers.

30 This sub-section is based on Mirella Klomp and Marcel Barnard, "Sacro-Soundscapes: Interpreting Contemporary Ritual Performances of Sacred Music through the Case of The Passion in the Netherlands", International Journal of Practical Theology 21, no. 2 (2017), 240-258. DOI: 10.1515/ijpt-2016-oo3o.
} 
Music and narrative. The entire performance each year consists of a unique and carefully composed blend of elements comprising a selection of secular Dutch popular music and a narration of the passion based on the gospels. This combination plays with the familiarity of the songs and the unfamiliarity of the passion narrative (or vice versa for many of the Christians in the audience). Although this narration is more or less the same each year, the selection of hit songs is new every time and has an effect on the meaning of the narrative will be emphasised in particular years. ${ }^{31}$ The liquid nature of popular music culture - demonstrated by the way in which hit songs constantly compete for the current number one spot in the music charts - here intersects with the biblical narrative. The blend is relentlessly temporary and made for a specific performance; afterwards it dissolves.

Location. 'The streets of Gouda are our Jerusalem!' the narrator proclaimed at the beginning of The Passion's first edition in 2011. In subsequent editions, the organizers had the event travel through the country: The Passion is an event on the move. It is a spatial practice that claims to turn a particular city into a sacred site (see Chapter 4). Every year, the producers look for particular spots to stage particular scenes. Where to locate the garden of Gethsemane in this city? Which cafeteria or herring cart to choose as the place where Jesus' friends collect the bread and fish for the Last Supper? In this way the passion narrative is firmly grounded in the city where the performance takes place. It brings the narrative closer to Dutch soil. After the performance, the stage is deconstructed.

Performers. The actors and singers that take up a role in The Passion differ each year. During the media campaign preceding The Passion, performers are mobilised to promote the event. They give interviews to newspapers and magazines, and they appear in late night talk shows where they plug The Passion. The annual changing of the cast means that the images of the staged characters are portrayed differently every time: every year they are interpreted anew, by producers, performers and public alike. Two examples may be helpful here. In 2014, a Dutch actress in her fifties known for her cabaret performances played the role of Mary-the-mother-of-Jesus. In the years running up to the performance, she had been quite open to the public about the fact that she had lost her own child fifteen years before, and she addressed this issue

$31 \quad$ A few exceptions confirm this rule: 1) the song "Open" by pop group The Scene that was used in 2011 returned in the 2016 edition; 2) "I cannot do it on my own" by De Dijk was used in 2013 and in 2017; 3) the song "Black-white" by 'Frank Boeijen Groep' was the only song that was used in all editions. On the latter, see the discussion in Chapter 6, right before the Conclusion of that chapter. 
in interviews preceding the performance of The Passion. The personal loss of this mother 'coloured' the meaning of the song: it lit up the suffering of Mary and all other mothers who had lost their children. In 2012 as well as in 2015, Black gospel singers with a Christian background performed this role, which shifted the topic to the religious meaning of Mary as mother of God, and, in particular, to the personal belief of these performers. Thus, the meaning of the songs, whether ascribed by organizers, performers and/or the audience, is not fixed but fluid, and depends on a constantly changing combination of various elements.

Motto. The first edition in 2011 was strongly aimed at the youth. ${ }^{32}$ From the Rotterdam edition onwards, the organizers each year linked the theme of suffering, crucial to the passion narrative, to a particular moment in the history of the city or a current theme in society. The mottos, although not always notably presented, are often deducible from the opening phrases of the narrator, and differ from one year to another. ${ }^{33}$ In 2012, the theme of suffering was related to the city centre of Rotterdam that was destroyed by aerial bombardments in World War II. In 2013, The Passion was staged in The Hague, the national parliament providing the backdrop to a story that was framed as being primarily about (lack of) peace, (in)justice, and leadership. In 2014, the event took place in Groningen and highlighted the theme of loneliness, something from which many people in Dutch society suffer, although not very explicitly. ${ }^{34}$ In 2015, The Passion was staged in Enschede, shortly before the fifteenth anniversary of the catastrophic fireworks explosion that in 2000 destroyed one of the residential areas of the city. In 2016, the crucial theme of suffering was related to taking refuge: a link was made to Amersfoort's commemoration of Belgian refugees who fled to the Netherlands during WwI, but also to the influx of millions of refugees coming to Europe. In 2018, cultural diversity was thematised, as the performance took place in an area of Amsterdam where over $6 \circ \%$ of the inhabitants has a non-Western background (an area that celebrated its

32 The immediate cause for Doornbos to speed up the preparation for the first edition was "a research report indicating that three out of four young people did not know what Easter is about". As I have not been able to find out the details, it remains unclear where this report came from or what research it was based on. Doornbos, interview, September 17, 2015 .

33 Reinder van Dijk, producer on behalf of KRO-NCRV, informal conversation with MK, September 24, 2015.

34 A news report of the National Institute for Public Health and the Environment published in 2013 showed that according to their research almost $40 \%$ of Dutch adults feels lonely. See: RIVM, "Bijna veertig procent van de volwassen Nederlanders voelt zich eenzaam", September 30, 2013. https://bit.ly/2MrHctg. Last accessed May 10, 2020. 
5oth birthday in 2018). The 2019 edition tied in with the festivities of the 40oth commemoration of the Synod of Dort (a link with the passion narrative that was not so tight and also a little 'churchier' than in previous editions), but also had a second theme: the issue of loneliness that was elaborated more explicitly than in 2014, particularly by means of the final song of the event: "You are not alone". In general, in the course of time, the choice of mottos has turned The Passion into a more socially and politically involved event. ${ }^{35}$

Audience. Since The Passion is a once-a-year event in a particular Dutch city, it has a changing audience. Depending on where it is staged, different people will or will not come to the square, and will or will not watch the Tv broadcast. ${ }^{36}$ From the start of the rehearsals on the afternoon of Maundy Thursday until after 10 PM, hundreds of people fill the square. Some just stop by on their way home, others come early to be sure of a good view of the stage. During the performance people continually enter and leave around the edges of the square, joining in and dropping out as the performance progresses. The same goes for the audience watching the passion on $\mathrm{TV}$, this is also a liquid audience that changes over the course of the broadcast. Viewers tune in at different points before, at the start of, and during the show. ${ }^{37}$ Some viewers of course continue with their daily routines as the show is broadcast, and may also change the channel (or switch the TV off) before the end of the show. Since the broadcast is repeated twice over the course of the Easter weekend, and remains online available for a number of years afterward, the audience is also fluid over time and exists in a constant state of flux.

\section{Producers: Shaping the Ritual}

The large audience, viewing figures, and media attention which I have described already indicate the 'success' of this ritual in terms of popularity and growth. The predominantly positive reception of the first edition in Gouda was crucial for subsequent productions: the success seemed to generate more

35 See Chapter 6 for an elaboration of how public events like The Passion mirror society's self-understanding.

36 In 2015, The Passion was staged in the eastern part of the country. Viewing figures show that viewers from the eastern part were overrepresented among the total viewing audience. Compared to previous years, relatively fewer viewers from the country's three largest cities watched.

37 E.g. in 2017, 2.2 million viewers had tuned in at 8:34 PM (the scheduled starting time), and this number increased to 3.1 million at 9:54 PM. Source: PDF-document by Petra Moonen (market researcher at KRO-NCRV) shared with MK, June 6, 2017. 
attention in the years that followed. How do the producers, in their design of the ritual, contribute to the popularity of this event? Five factors seem to contribute to the popularity of this event in a de-churched society.

First of all, the mixture of fixed and liquid elements appears to be crucial in this respect, as they contribute to what the producer calls "a TV principle", that people like to know what they are looking at. ${ }^{38}$ There must be a clear promise to the viewer. "The promise of The Passion is very clear, because we all know how the story ends, and we like that. Yet, although we already know the end, we do not know who the performers will be, how and with which songs it will be staged, and what will touch us this time. That is a surprise, time and again. Apparently, that is sufficient, so it keeps growing". ${ }^{39}$

Secondly, the language used in The Passion, as well as the meaning of the narrative, remains quite open. There is no heavy Christian jargon, nor are there clear dogmatic proclamations of firm theological messages (e.g. 'Jesus died for our sins'): the production team leaves it up to each individual what they make of it. In the past, the Evangelical Broadcasting company, in particular, has had a public image as a broadcaster of radio and TV programs with the constant aim of evangelisation. Although EO is only one of the three main organising parties, I have regularly heard people commenting that they were surprised about this openness and the apparent absence of obvious attempts at evangelisation.

Thirdly, the passion narrative, which many people in Dutch society are unfamiliar with, is made easily accessible both through the open-air performance on the square and through the TV broadcast. As I have already mentioned, people freely enter and leave the square during the performance, there is no need to pay for a ticket, nor are people subject to security checks. ${ }^{40}$ The live

38 Doornbos, interview, September 17, 2015.

39 Doornbos, interview, September 17, 2015.

40 At least, up until the 2015 performance. In 2016, the performance in Amersfoort was an exception, because it took place only two days after the three coordinated suicide bombings in and around Brussels (two at the Airport Brussels Zaventem, one in a metro station in the centre of Brussels). As in Belgium, people the Netherlands were terrified that more attacks would follow. The mayor of Amersfoort announced increased security measures prior to and during the performance of The Passion. Coats, bags and other things would be checked upon entering the square. Yet this security check did not influence the number of people attending the performance on the square. This might also have been related to the actor playing Judas in the newspapers calling for the audience to come to the square precisely because of the bombings: "Terrorists seek disruption and hatred, therefore performing this narrative about love, compassion, peace and hope is the only answer to that, as far as I am concerned". Algemeen Dagblad, "De Buisonjé: kom allemaal 
TV broadcast in a primetime slot, accessible online via livestream, also contributes to this accessibility. This enables many people, particularly those for whom the threshold of entering a church is too high, to learn about the passion narrative. It is interesting to see that, although in churches the annual commemoration of the suffering, death, and resurrection of Jesus Christ was, of course, never abolished, it is still read, recited, sung, or otherwise performed in many congregations during Holy Week and Easter. A number of congregations over recent years have embraced The Passion as performed in the public square, and brought it (back in)to the church. Local congregations put up large screens and invite people to come and watch The Passion in the church via live stream, or take up the format of The Passion as a model for creating their own passion (see Chapter 2).

Fourthly, The Passion is a real spectacle with high-quality sound and light effects and images. It appeals to people's corporeality, which, as Tex Sample suggested as long ago as 1998, is characterised in our wired world by three things: an engagement with the world through images, the encoding of sound on our (physical) beings as beat, and an ongoing process in which sound obtains visualisation..$^{41}$ The production team have shown themselves to be well aware of the ways in which sound, light and images are able to engage people and clearly know how to realize a spectacular event. The performance is wellorchestrated in this respect, with the best camera crew and director commissioned to film the event, and the best audio-visual technical facilities utilised in bringing that to the audience. This strategy has paid off as many people find the way The Passion is shown to be (very) appealing. ${ }^{42}$

Fifthly, the strong connection that is made within Passion performances between this Christian narrative and the broader culture (esp. fan culture, digital media culture and economic culture) makes an important contribution to the popularity of this phenomenon. By involving Dutch singers and actors in the performance, the producers also engage their fans, thus linking these devoted

naar The Passion als signaal", March 24, 2016, http://www.ad.nl/binnenland/de-buisonje -kom-allemaal-naar-the-passion-als-signaal a13bee33/. Last accessed May 10, 2020.

Tex Sample, The Spectacle of Worship in a Wired World. Electronic Culture and the Gathered People of God (Nashville, TN: Abingdon Press, 1998). Also see Klomp, The Sound of Worship, 229-23o.

The 2015 GIN research project explicitly contained a question on the appreciation of The Passion. In answer to the question asking people to evaluate the way in which The Passion was depicted, $37 \%$ indicates they find it appealing, $23 \%$ strongly appealing, $22 \%$ is neutral, $9 \%$ disagrees and 6\% strongly disagrees. Bernts and Berghuijs, God in Nederland 1966-2015, 219 . 
followers to others in the audience who may have different motivations, e.g. those who like to get together with others and participate in a collective ritual (see below), those who are interested in modern modes of religious expression, those who enjoy the current 'festivalisation' of our culture and enjoy 'the eventful city' where every possible occasion is used as an excuse to celebrate, and those who are simply curious. ${ }^{43}$

By employing and engaging in a range of media strategies, the broadcasting companies form a strong connection between the passion narrative and digital media culture, which in turn is closely linked with the phenomena of fan culture. They make use of public media by having producers and performers invited to appear on talk shows and having them interviewed on radio, on TV, and in newspapers and magazines. With slick social media visuals, posts that offer a glimpse behind the scenes, questions, giveaways and riddles they attract people's attention they encourage 'likes', 'shares' and 'retweets', and thus evoke responses. In 2015, the official Facebook page of The Passion, with the addition of 33,021 new followers reached a total of nearly 80,ooo Facebook likes. In Holy Week, over 60,389 tweets including the hashtag '\#tp15' were posted, and 'Passion', 'Judas', and 'Mary' became trending topics on Twitter. ${ }^{44}$ Whilst the locations of the first five editions of The Passion were revealed at press conferences in the cities where the event would be staged, the organisation chose to directly reveal the location of the sixth edition to the public using street art. ${ }^{45}$ In 2016 the announcement of the person cast to play the role of Jesus followed a similar pattern, being revealed directly to the public through social media. On February 2, 2016 at 8.30 AM the following post appeared on the Facebook account of The Passion: "We are going for it! Together we will today reveal the person who plays Jesus. \#whoisjesus. Your share brings the revelation of Jesus one step closer". At 11.11 AM and 1.21 PM two more postings appeared, with the news that $47 \%$ and $70 \%$ respectively of the required (and unrevealed) number of shares had been reached. In a Facebook-posting at 2.32 PM the name of the actor was revealed. On the same day, the Dutch Wikipedia-page of this actor,

\footnotetext{
43 Greg Richards, Leisure in the Network Society. From Pseudo-Events to Hyperfestivity? (Tilburg: Tilburg University, 2010), 6.

44 Source: Wim Steeneveld (Research Department of organising Broadcasting company Eo), informal documents shared with MK, April 17, 2015.

45 On September 2, 2015 the makers revealed the next location of The Passion by means of street art: they had a cross painted on the city square in Amersfoort where the stage would be located. This painting in turn was recorded on video, which appeared online the next day: "VIDEO: The Passion in Amersfoort", NPO Start, http://www.npo.nl/video -the-passion-in-amersfoort/o3-o9-2015/POMS_EO_1870034. Last accessed May 10, 2020.
} 
Martijn Fischer, was edited and his role in the 2016 edition of The Passion was added. ${ }^{46}$

Another important context in which to situate The Passion is, of course, an economic one. The story of the suffering and death of Jesus Christ not only mixes with fan and digital media culture, but also with commerce - retailers benefit directly. A lingerie shop in Groningen in 2014 advertised 'The real passion' in its storefront window with a mannequin dummy in lingerie holding a large white cross. In 2013, when Doornbos drove into Den Haag, he saw a local pizza bakery advertising 'The Passion-pizza', "a pizza with salami in the shape of a cross". ${ }^{47}$ Since The Passion has become such a large event, municipalities in recent years have lined up to welcome The Passion to their cities. As co-operators in organising the event, their share of the responsibility mainly consists in the provision of public security during Maundy Thursday, the deployment of police and security guards, and the making-available of additional auxiliary services. Recognising the value of The Passion for city marketing strategies, various cities now compete on an annual basis to win the bid. ${ }^{48}$ According to the press officer of the city of Den Haag, where the event was staged in 2013, "The Passion is like a moving glossy for a city".49 He highlighted the way in which the cameras bring locations from The Passion - the main stage (and the shops around), various locations in the city where particular scenes are filmed, and hot spots which the procession passes by - into vision. It draws people's attention to the city as a potential destination for a day out. After The Passion, tourist offices offer package deals, including hotels, tours, tickets. Guided tours of churches are offered, walking tours around places of religious heritage in the city, with coffee and cakes, and lunch at a religious venue. ${ }^{50}$ Different commercial parties contribute, sometimes unwittingly, to

46 "Wijzigingen: Martijn Fischer", Wikipedia, version of February 2, 2016, https://nl.m .wikipedia.org/wiki/Speciaal:MobielVerschillen/45913837. Last accessed May 10, 2020.

47 Doornbos, interview, September 17, 2015.

48 "Enschede spent 186,ooo euros on The Passion, and in one night received 646,ooo euros. Groningen spent around 200,000 and received 553,920 euros. (...) The effect of The Passion on one's city is priceless", according to Barbara Risselada, city marketer for the city and province of Groningen. Algemeen Dagblad, "Amersfoort mag blij zijn met het krijgen van The Passion', January 23, 2016, http://www.ad.nl/amersfoort/amersfoort-mag -blij-zijn-met-het-krijgen-van-the-passion ae35ccfe/. Last accessed May 10, 2020.

49 Newspaper interview with press officer Coen van Kranenburg for the municipality of The Hague, Metro. "The Passion is bewegende glossy voor stad". April 2, 2015. https:// www.metronieuws.nl/binnenland/2015/o4/the-passion-is-bewegende-glossy-voor-stad. Last accessed May 10, 2020.

$5^{\circ}$ vvv Amersfoort, "The Passion 2016", http://www.vvvamersfoort.nl/The-Passion-2016. Last accessed May 1, 2016; Amersfoortse gidsen, "Kerkenwandeling Amersfoort", http:// amersfoortsegidsen.nl/culturele\%2ouitjes/kerkenwandelingamersfoort.html. Last accessed May 1, 2016. 
the spread of the passion story. It appears that, within the dynamics of this living tradition 'surrendering' and 'handing down' (both translations of the one Latin verb trādere) of age-old practices are closely connected.

All in all, the strong format, openness, accessibility, and high quality of the production, alongside strong ties with broader cultural developments, are means by which the TV producer and the broadcasting companies make this passion narrative a unique, big and generally well-received event.

\section{Public: People and Their Reception}

What can be said about the public? I have no separate statistics about the audience in the square, except that police and security services normally guarantee safety for a maximum of 20,000 people. From fieldwork between 2011-2019 I can tell that the audience in the square is very diverse: both old and young, on their own or together with relatives, parents with children of various ages (both infants and adults), together with friends or in larger groups of friends or peers, such as teen catechesis groups. It is important to emphasize that those who attend the event in the square are definitely not all Christians - I spoke with many people who were just curious, who lived nearby, who liked mass events of all kinds, came for the show, for solidarity, or because they found it spectacular. ${ }^{51}$ The Passion is explicitly not simply a celebration produced for Christians. In 2015, almost 50\% of the people my colleagues and I spoke with at Van Heek square in Enschede said they were not (or were not at all) active in terms of Christian faith.

Alongside informal conversations, such as those above, I gathered morerepresentative facts and figures on TV-viewers following the events, mainly from the independent television audience measurement service. I also have information from the GIN-questionnaire from mid-2015, which contained three questions explicitly relating to The Passion, although whether individuals watched TV or physically attended the event was not further specified in this questionnaire. So, who watches The Passion, how do they value it, and what are their (religious) ideas and practices?

$5^{1}$ Informal conversations as part of ethnographic fieldwork by Mirella Klomp, Marten van der Meulen and Anita Zijdemans prior to the fifth edition of The Passion. We spoke to 69 people altogether; 30 out of those indicated they were not (at all) actively involved when it came to religion. Fieldnotes April 2, 2015. During earlier and later editions of The Passion we spoke with fewer people, but these conversations generally confirmed that the event is not just a celebration for Christians. 


\section{Who Watches The Passion and What Do They Think of It?}

In the Netherlands, people's interest in The Passion is diffusely distributed: we find both appreciation and dislike through all age-groups, all social classes, and all educational backgrounds, with one exception: highly-educated people are not too fond of the phenomenon.

In $2017,61 \%$ of the viewers aged 6 or higher were female, according to the audience measurement service, with a relatively strong representation of female viewers in the age range $35^{-49}$. Of the lifestyle group that normally watches TV on the three public TV channels NPO1, NPO2 and NPO3, 'traditional regional residents' and 'committed believers' were particularly likely to watch, more so than 'practical family people' and 'busy commuters' (NPO1); with 'committed believers' more likely to tune in than the 'critical seekers of perspective' (NPO2). ${ }^{2}$

Respondents to the GIN-questionnaire (50\% of whom had watched The Passion at least once, $25 \%$ more than once ${ }^{53}$ ) rated the event(s) as satisfactory, achieving a rating of 7 , on a 1-10 scale. ${ }^{54}$ As this already demonstrates, viewers' judgment is generally positive, and $6 \circ \%$ find The Passion engaging. Respondents' frequency of viewing is more or less proportional to the number of situations from a representative selection of events in public life in which they claim to have felt united with other Dutch people, as Chart 1 shows.

Whether The Passion also contributes to the revitalisation of people's faith is a somewhat different question: $16 \%$ indicated that The Passion strengthens their faith, another $16 \%$ indicated that it arouses their curiosity about Christian faith, yet the percentages indicating the opposite are much higher: $58 \%$ for both questions. ${ }^{55}$ Obviously, the judgement of those who have watched more than once is generally more positive. But even in this category only a quarter indicated that The Passion strengthens their faith and engages them. For this group, other motives also appear to play a part (we will come back to this below).

People find The Passion engaging for various reasons. Some people, for example, appreciate it for its modern musical-style:

52 Source: PDF-document created by Petra Moonen, market researcher at broadcasting company KRO-NCRV.

53 See Appendix 2, Table 1. All tables in this appendix are taken from an analysis of GIN-2015 data by sociologist of religion Joep de Hart (unpublished document obtained from him in 2016, reproduced with permission, translated into the English by $\mathrm{MK}$ ).

54 It is unclear to which particular edition this score refers: considering that the questionnaire was filled out a couple of months after the 2015 edition, it may well be that the score refers to an event like this in general. 


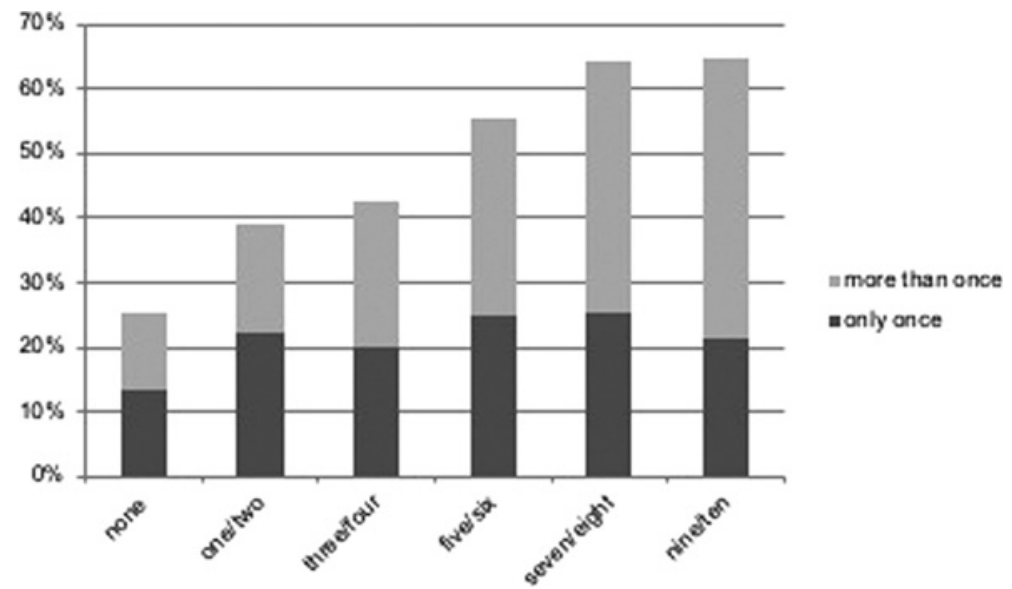

CHART 1 Frequency of viewing classified by the number of situations in which respondents claim to have felt united with other Dutch people

A total of ten situations were presented to the respondents: sports competitions, the death of a famous Dutchman, Koningsdag, the commemoration of the Second World War, parliamentary elections, a protest meeting, the commemoration of a disaster, Prinsjesdag, a large fundraising campaign, a royal wedding. Cf. Appendix 2, Table 11 .

SOURCE: JOEP DE HART (GIN 2015)

The musical-aspect is what I find attractive. The performers run the show together, I like the idea of doing it like this. The atmosphere is pleasant, last year the rain also contributed to the atmosphere. Last year I found the duet of Jesus and Judas, where two songs were mixed, a very nice choice. The combination of those covers songs: it was well chosen, it matched the narrative, the words, and the time that we live in. ${ }^{56}$

Others mainly seem to appreciate it because of the participation of famous actors and singers. In 2011, during fieldwork in the Market Square in Gouda, I stood between the crowds and overheard two young men, aged around 17, talking to each other. They appeared to live in the area. In that first edition, the role of the mother of Jesus was played by singer Do - a young, good-looking well-rounded lady with long blond hair, whom some young men obviously found physically attractive. ${ }^{57}$ Prior to the performance, one man jokingly said

56 Quotation taken from an interview I did with a group of two men and two women in their late twenties/early thirties attending The Passion on the Van Heek square in Enschede, prior to its fifth edition on 2 April 2015 .

In 2008, singer Do posed nude for the Dutch Christmas edition of Playboy. 
to another: "I have come to kiss singer Do. That kiss could now finally come true". In the rest of their conversation, the content of the play did not really seem to be important to them.

\section{Viewers' Social-Structural Characteristics}

The GIN-2015 research confirms the fact that audiences tend to be composed more of women, middle-aged and older people, and people with middle levels of education than of men, younger age groups, or people with either particularly high or particularly low levels of education. ${ }^{58}$ Chart 2 shows that more recent birth cohorts tend to watch the event less than older generations, although it is worth noting that they also tend to watch less TV and that internet use, for example, is not measured in these statistics.

However, among those who have watched (Chart 3), it is the later generations (born after 1970) that show the most interest in faith. They also indicate often that The Passion appeals to them and often rate productions with a high score. With the qualification that these statistics only report on television use, data relating to The Passion also suggest a comparatively low affinity with Christianity among younger age groups in comparison to the older age groups, whilst simultaneously displaying a stronger involvement among the part of the demographic that is (still) interested and is aware of it.

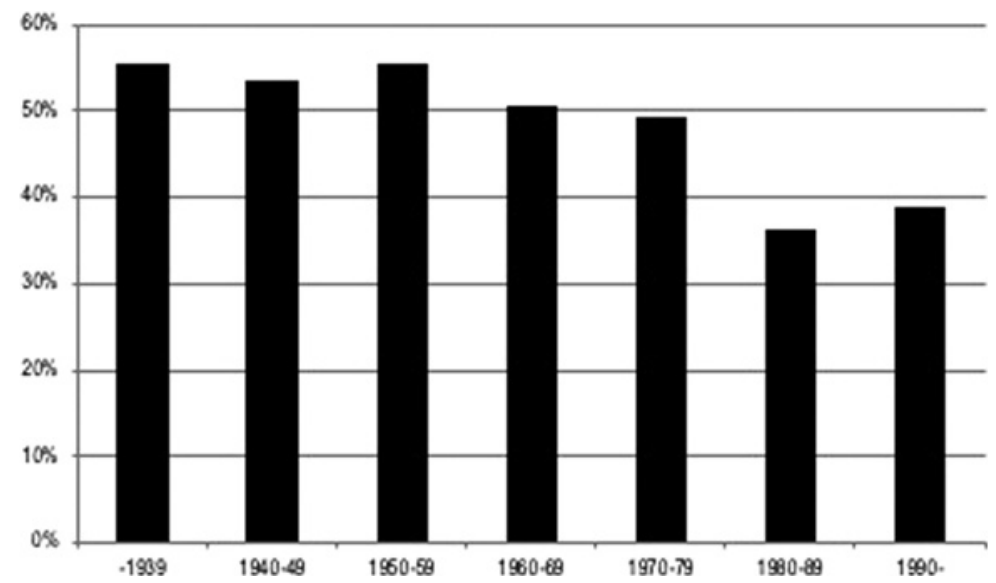

CHART 2 Viewers who have watched The Passion at least once, according to birth cohort (percent)

SOURCE: JOEP DE HART (GIN 2015)

$5^{8} \quad$ See Appendix 2, Table 3 . 


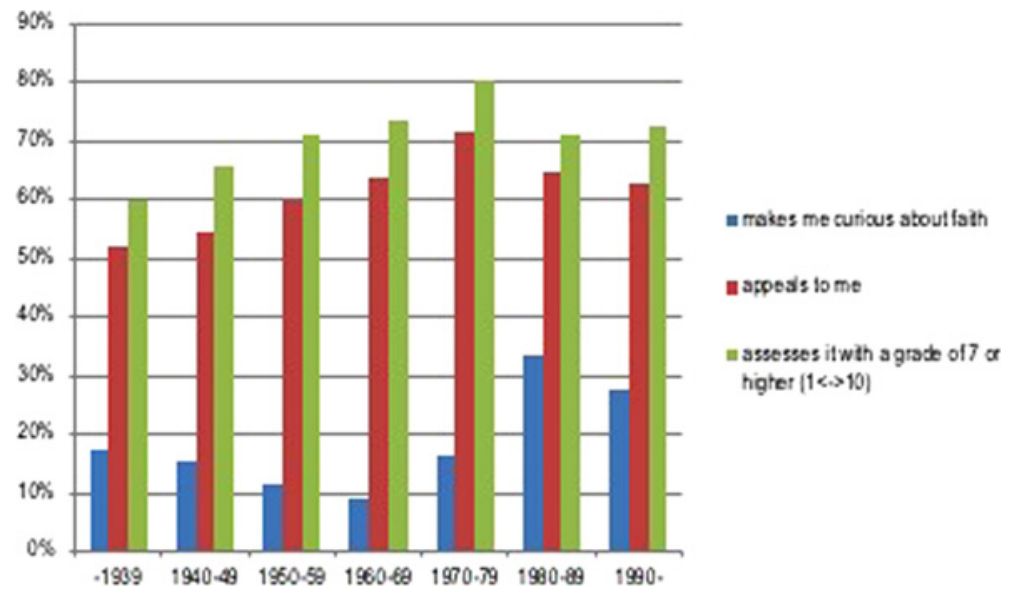

CHART 3 Appreciation of The Passion among those who have watched one or more times, according to birth cohort (percent)

SOURCE: JOEP DE HART (GIN 2015)

As we have already stated, elderly people in general spend more time watching TV than, for instance, younger people. The 15-24 age-group rates The Passion higher (7.0) than the $65^{+}$age-group (6.8), but only $39 \%$ of the younger demographic have ever watched The Passion, against $55 \%$ of pensioners. Another factor to take into account is that not watching The Passion may well also involve a judgement, which is why the questionnaire differentiated between watching only once and more than once. In general, the 15-24-year-old offer higher ratings for The Passion than the $65^{+}$age-group when it comes to the question of whether it engages them (61\% versus $52 \%)$, and whether it arouses curiosity about Christian faith $(28 \%$ versus $12 \%)$, yet the audience rating is lower amongst the youth as such. This indicates that young people who watch The Passion tend to belong to a more-highly-motivated category in relation to their peers, a fact which parallels the outcomes of several scP-reports. ${ }^{59}$ In general, young people are moving away from church and religion, but those who somehow sympathize with church and religion have become pockets of devoutness and even 'excel' above older generations in this respect.

Amongst the people who watched The Passion at least once, those who live in urban areas, those older than 65 , and those more-highly educated are less

59 Joep de Hart, Geloven binnen en buiten verband: godsdienstige ontwikkelingen in Nederland (Den Haag: Sociaal en Cultureel Planbureau, 2014). Joep de Hart and Pepijn van Houwelingen, Christenen in Nederland. Kerkelijke deelname en christelijke gelovigheid (Den Haag: Sociaal en Cultureel Planbureau, 2018). 
enthusiastic about the event. The highly-educated tend to rate it as 'kitschy' more than others. Those who find The Passion engaging are often viewers in the 35-44 age-group, and those whose curiosity about Christian faith is aroused are more often viewers between 15 and 34 years old. ${ }^{60}$

\section{Church Background/Affiliation}

There is a demonstrable relationship between interest in The Passion and church-affiliated religiosity. Frequent viewers are mostly people raised in reformed traditions, and churchgoers (regular churchgoers more than nominal members). Those whose faith is strengthened by The Passion and those whose curiosity is aroused by the event are more-often members of the Protestant Church in the Netherlands (PCN), and churchgoers (to either Roman-Catholic churches or churches belonging to the PCN). ${ }^{61}$

Both positive and negative responses to The Passion can be found at both ends of the spectrum: appreciation of the event is found among believers and non-believers, and the reasons vary. In 2015, at Van Heek square in Enschede, a teenage catechesis group from the local Protestant congregation of a Dutch rural village was enthusiastic. They found the event to bring the story closer:

It is special, an old story with such a new look. (...) It is more accessible than hearing the narrative in church. There is contemporary music and you really experience the story. The characters are also more real than in church. With [Roman soldiers wearing the costumes of] the anti-riot squad and so on. ${ }^{62}$

On social media, many self-declared atheists over the years have indicated that The Passion somehow touches them, as demonstrated in the following tweet: "I am not religious as such, but a good biblical narrative gives me goose bumps". ${ }^{63}$

Criticism also comes from various (Christian and non-Christian) quarters and relates to various aspects of The Passion. Christians have protested against the commercial aspects that are attached to The Passion as well as the fact that it is 'too much fun': "Jesus dies without cocktail nuts" (in the view of this

\footnotetext{
6o See Appendix 2, Table 4 .

61 See Appendix 2, Table 5.

62 Ethnographic fieldwork by мк on the Van Heek square in Enschede before the fifth edition of The Passion, April 2, 2015.

63 Excel-file with tweets on The Passion 2015, nr. 14894549621, tweet sent on April 2, 2015, 8.31 PM.
} 
blogger, the crucifixion does not go well with the practice of having a nice, relaxed evening on the couch in front of the tv and with a bag of peanuts within arm's reach). ${ }^{64}$ But they have also objected to the lack of a clear theological message: The Passion is "biblical fundamentalism for rich westerners", 65 and to the shape of the performance: "Performance 'The Passion' in Gouda by EO and R KK is violation of and contempt for the gospel", a tweet which was followed by a reference to the Heidelberg Catechism (see also Chapter 4). ${ }^{66}$ Dislike of the event from non-Christians often relates to its shape (see Chapter 4) and can sometimes lead to jokes: “They are gonna need screws, 'cause I don't think this Plexiglas will hold nails... \#tp15". ${ }^{67}$ The broadcasting companies and the producer are aware of the criticism and in interviews repeatedly said that they constantly reflect on the question of whether or not to continue with The Passion: "Do we do this because of its success or because we really believe that the story must be told? That is at least something to dwell upon". ${ }^{68}$

\section{General Ideological Traits}

Both frequency of viewing and verdicts on The Passion are also related to the number of functions that individuals ascribe to religion. Generally, the more functions people consider religion to have, the higher their rating: those who tend to find religion important on many occasions, value The Passion more

64 Blog by Roman-Catholic blogger Eric van den Berg: "The Passion Gouda: Jezus sterft zonder borrelnootjes". April 21, 2011. https://www.mediakathedraal.nl/the-passion-gouda -jezus-sterft-zonder-borrelnootjes/. Last accessed May 10, 2020. Also see the sequel that he posted on the same day: Berg, Eric van den. "The Passion Gouda: Jezus sterft zonder borrelnootjes II". April 21, 2011. https://www.mediakathedraal.nl/the-passion-gouda-jezus -sterft-zonder-borrelnootjes-ii/. Last accessed May 10, 2020.

65 Quote from Roman-Catholic theologian Hendro Munsterman with whom I [MK] crossed swords in 2015 in a fourfold blog-conversation on The Passion. See: Munsterman, Hendro and Mirella Klomp, "Briefwisseling The Passion". NieuwWij, April 7, 2015, http://www .nieuwwij.nl/verdieping/briefwisseling-the-passion-de-eerste-brief/ and consecutive letters. Last accessed May 10, 2020.

66 Tweet by @papavanlara, most likely a reformed Christian (judging by his tweets), April 21, 2011. Reference is made to Lord's Day 35, question 98 in Heidelberg Catechism: PapavanLara (@PapavanLara), “God wants his people to be taught not by means of dumb images but by the living preaching of his Word". Cf. "Lord's Day 35", Heidelberg Catechism, http://www.heidelberg-catechism.com/en/lords-days/35.html. Last accessed May 10, 2020 .

67 Tweet by Sergio M. Samson (@SergioMSamson), April 2, 2015, 7:56 p.m.

68 Arjan Lock, director of Eo, in an interview. Cf. José Vorstenbosch, "Het verhaal van Jezus gaat over ons allemaal", Volzin. Magazine voor religie en samenleving 3 (2016), 44-47, 45. In interviews conducted by MK, both Reinder van Dijk (KRO-NRCV) and Jacco Doornbos (Eye2Eye Media) indicated that they were similarly concerned with this question. 
highly and have generally also watched it more than once. Also, the more often they watch, the more it engages them, the more it strengthens their faith and makes them curious. ${ }^{69}$

Upon examining these functions in more detail, we can see that people in general do not really seem to relate their perception of The Passion to the functions they attribute to religion. For those who consider religion to play a role in national commemorations, collective identities, ethics or morality, private or family life, The Passion does not really arouse curiosity about Christian faith, nor does it really strengthen their faith. They may experience that their faith and/or curiosity are strengthened or aroused elsewhere, or nowhere at all. The Passion mainly simply engages them as an event. ${ }^{70}$

\section{Spirituality}

Are those who watch The Passion somehow involved in 'spiritual practices'? As has been reported before, those who see themselves as 'spiritual but not religious' often relate religiosity to institutionalised Christendom and therefore normally do not want much to do with it. ${ }^{71}$ Does The Passion reach these people? Less than those who consider themselves religious, but they do seem to be more open to The Passion than to ecclesial religiosity, as the following tables show. The same goes for those who consider themselves 'neither spiritual nor religious. ${ }^{72}$

Non-affiliated spirituality seems to be positively associated with The Passion, although the relationship is less strong than that between The Passion and church-affiliated religious people. ${ }^{73}$ Respondents who indicate that they have participated in a pilgrimage slightly stand out. They watch The Passion less frequently, they rate it less highly and often find it to be 'kitschy'. Further analysis shows that this is due to an overrepresentation of Roman-Catholic churchgoers in this group who show a strong affinity with Christendom, hold the opinion that church is in keeping with their view of life, and who consider themselves both religiously and spirituality interested. Part of these hard-core Roman-Catholics may find that their own church offers enough of what The Passion also provides (and apparently in a less 'kitschy' fashion).

\footnotetext{
69 See Appendix 2, Table 6.

70 See Appendix 2, Table 7.

71 Joep de Hart and Paul Dekker, "Floating believers: Dutch seekers and the church", in $A$ Catholic Minority Church in a World of Seekers, Christian Philosophical Studies XI, eds. Staf Hellemans and Peter Jonkers (Washington D.C., Cardinal Station, 2015), 71-96.

72 See Appendix 2, Tables 8 and 9.

73 See Appendix 2, Table 10.
} 


\section{Collective Cohesion}

Alongside religious aspects, a longing for experiences of collective identity seems to play a part in experiences of the event. The more frequently people feel united at different public occasions, the more often they watch The Passion. ${ }^{74}$ Regression analysis suggests that the popularity of The Passion is related to a longing for collective cohesion and a shared need for a larger family feel' in an individualised, depillarised society, even when somewhat fleeting in nature. Alongside people with a religious background, those who tend to identify with their compatriots relatively strongly in national events showed more interest in The Passion and felt more engaged by it than those who did not tend to identify with others so strongly on such occasions. This may be an instance of 'collective effervescence' that gives birth to religious or sacred experience: the performance of this ritual enables people to be excited together and be one again for a while, to share moments that break the daily grind, and break through old separations and familiar social environments while employing a religious narrative and a religious object such as the cross. ${ }^{75}$

\section{Conclusion}

The Passion has transferred the passion performance from the church to the Dutch public sphere and transformed it into a multi-media event. With every

74 See Appendix 2, Table 11.

75 Cf. the quotation from two female inhabitants of Enschede, at the beginning of Chapter 3. There are many more: fieldwork yielded many quotes of people who felt 'lifted', 'excited' and 'united' in an unexpected way, which reminded me of the electricity that sociologist Emile Durkheim, who coined the term 'collective effervescence', speaks of in Émile Durkheim, The elementary forms of religious life (New York: The Free Press, 1995) (originally published in 1912). Cf. also the following concise and more complete definition: "Collective effervescence refers to moments in societal life when the group of individuals that makes up a society comes together in order to perform a religious ritual. During these moments, the group comes together and communicates in the same thought and participates in the same action, which serves to unify a group of individuals. When individuals come into close contact with one another and when they are assembled in such a fashion, a certain "electricity" is created and released, leading participants to a high degree of collective emotional excitement or delirium. This impersonal, extra-individual force, which is a core element of religion, transports the individuals into a new, ideal realm, lifts them up outside of themselves, and makes them feel as if they are in contact with an extraordinary energy", "Émile Durkheim (1858-1917)", Internet Encyclopedia of Philosophy. A Peer-reviewed Academic Resource, http://www.iep.utm.edu/durkheim/. Last accessed May 10, 2020. 
performance of The Passion the Christian passion narrative hits the ground and is staged in a contemporary ritual-musical shape. It aims to focus on those people in Dutch society who are unfamiliar with a story that is at the heart of Christianity. It connects the ancient gospels with contemporary network culture by combining the passion narrative with songs, celebrities, modern technologies and (social) media, and, in spite of critiques, manages to engage millions of people in this ritual practice. It does so in a way that, until recently, was rather unconventional: by creating and presenting a late-modern media spectacle on the suffering, death and resurrection of Jesus Christ.

This is achieved by a single production company and two broadcasting companies: producers, marketers, PR teams, and celebrities translate the passion narrative for the contemporary situation. In a way, they are the new priests, ministers, and church musicians of the 21st century, translating, actualising and contextualising the Word, and making it heard. In a society where institutionalised religion is losing ground, they offer a ritual with a clear and fixed format; a ritual that is highly fluid at the same time; a ritual that is open to a variety of meanings; a ritual that is easily accessible, creating a real spectacle of sound and light; a ritual that strongly connects with the broader culture in terms of fandom, digital media, the festivalisation of culture and the role of the market.

Those who watch this spectacle and feel attracted by it are predominantly women, people aged $5^{\circ}+$ and young people with a special interest in religion, they live in rural areas more than in large cities, often with no academic education, they are usually somewhat religious (often protestant) or people who consider religion as important for society, and they tend to attach importance to collective experiences and a sense of unity.

Dutch culture may no longer simply be characterised as Christian, yet the Dutch do not really manage, so to speak, to get beyond Christian narratives, images and rituals. They undeniably continue to reinvent their dealings with their Christian heritage, appropriating it to their liking. Insofar as it may be considered religion, The Passion shows that Christianity in the Netherlands is becoming light-hearted, casual, easy and flighty. 


\title{
The Scenery: Dwellings in a Sacro-Soundscape
}

\author{
With Marcel Barnard
}

The modern words of The Passion provide a new language for the message of Jesus.

It is a way to break through the muteness.

LEO FIJEN (head of broadcaster RKK), 5 December 2011

(interview by $\mathrm{MK}$ )

Following the debut of The Passion in 2011, with each new edition, various national media became increasingly interested in a phenomenon that appeared to be simultaneously new, hip and happening. ${ }^{1}$ Could I, as a scholar, please in an interview for radio/television/national newspaper explain how the makers came up with the brilliant idea of staging the narrative of the suffering of Jesus Christ in a musical show? In an effort to downplay the hype, one of the first things I used to say was that annual performance of the passion narrative was, in fact, a centuries-old practice. The recitation of specific Bible passages on the life, suffering and death of Christ went back to at least the 4th century CE. And a passion play in the open, in the market square of a city was not all that new either, as the passion of Christ had been the theme of many medieval religious dramas. Of course, this 21st century telling of the story, with lights, pop

1 This chapter contains material that was previously published as part of Mirella Klomp and Marcel Barnard, "Sacro-Soundscapes", and other material that was published as part of Mirella Klomp, "Joseph \& Jesus. Bible-based musicals and contemporary Passions staged in the public domain: an exploration of a research perspective", Yearbook for Liturgical and Ritual Studies 27 (2011), 49-65. The different authors' contributions to this chapter are as follows: Barnard originally wrote the section 'The changing religious landscape', the subsections 'Appadurai's five -scapes' and 'McAlister's religioscapes', the section 'The study of Sacro-soundscapes', and part of the conclusion. I amended the introduction, and wrote the section on 'Transfer and transformations of the Passion', as well as the subsection 'Soundscapes in Acoustemology and Theology'. I elaborated and adapted the entire text for the purposes of this monograph.

(C) MIRELLA KLOMP, 2020 | DOI:10.1163/9789004442948_004

This is an open access chapter distributed under the terms of the CC BY-NC 4.olicense, Klomp - 978-90-04-44294-8 
songs, and famous actors and singers on a stage, broadcast live on national TV stations was new and unprecedented but, at the same time, participating in this performance of the Christian passion narrative (in whatever role: as spectator, performer, or organiser) was yet another contextualised form of a ritual practice with distant antecedents in the Christian tradition. This message was often met with surprise, and the interviewers would often then steer the conversation in a different direction.

My typical response was actually a highly-simplified presentation of a development that was more complex than the 30 seconds of time offered in interviews allowed for. Indeed, The Passion is rooted in a longstanding tradition of reinterpretation, reinvention, and reconstruction of the passion form. But in Western cultures a process of transfer and transformation of musical forms rooted in Christian tradition has been going on for a couple of centuries. On top of that, the religious landscape has significantly changed in the past decades. Using the root metaphor of (a) play, we may say that the scenery of the play that we are looking at has altered. This deeply affects the ways in which people attribute meaning to the play, which in turn also has a knock-on effect on practices of religion, as we will demonstrate. After all, plays always take place amidst some kind of surrounding environment, which should, however, not be understood as a fixed backdrop: scenery influences a play, but a play in turn influences the scenery. The scenery in which The Passion is staged is the Dutch religious landscape. The longstanding tradition of reinterpreting, reinventing and reconstructing the passion is a crucial part of its history, its crossings and dwellings, its transfer and transformations.

In this second chapter, we examine what is going on in Dutch society when it comes to religion, by sketching the scenery that forms the backdrop for The Passion. This scenery is characterised by processes of transfer and transformation, thus in order to understand recent developments we must first briefly elaborate the history of the passion as a (liturgical-)musical form. Moreover, we argue that the changing nature of the play (again: as a metaphor for religious forms, language and repertoire) also changes our academic research and disciplines. After all, in order to be able to sketch the scenery of a play, we depend on words, concepts, and metaphors, and we rely on the tools and techniques used in various disciplines when searching for the language most suitable to describe it. Sometimes we find apt and helpful notions, and sometimes we do not. In describing the scenery for The Passion we find ourselves in the latter kind of situation: Christian ritual musical practices have been transferred to extra-ecclesial domains (and back to the ecclesial domain) has been going on, and practical theology - as much as related disciplines like ethnomusicology - lacks appropriate theoretical concepts in order to ade- 
quately interpret these practices. New concepts must, therefore, be developed in order to gain a better and deeper understanding of the phenomenon investigated. In this chapter, we will propose the notion of 'sacro-soundscapes' as an up-to-date theoretical concept for the interpretation of fluid Christian ritual-musical practices in late-modern culture. The fluidisation of these practices results in practical theological research that brings together a range of theories and fields and methods that together serve to create a better understanding of these practices (this very monograph aims to be an example of this development). Fluid practices require research that dares to surpass 'traditional' boundaries of (sub-)disciplines whenever these boundaries do not permit new practices to become the objects of research.

\section{The Changing Religious Landscape}

The Dutch late modern religious landscape is generally characterised by fluidity: it is dynamic more than it is static. Religious language, forms, practices and ritual repertoires over the last century have increasingly left the enclosed domains of the institutionalised churches and have migrated to other realms. Various scholars have characterised this process as a transfer and a transformation of religion and/or the sacred. ${ }^{2}$ Such relocations of Christian immaterial heritage take place against the background of a changing Dutch ecclesial landscape. A perspective from the ground still show the continuation if weekly patters of worship in churches and congregations, however, a bird's eye view on this landscape shows reduction and concentration. Institutionalised Christianity shows a downward trend. Estimations indicate that every week one or two churches and/or monasteries in the country are closed down. ${ }^{3}$ In the past two decades, churches lost on average 267 members per day. ${ }^{4}$ The 2004

2 Joep de Hart, "Summary. Keeping the faith?" The Dutch and their gods. Secularization and transformation of religion in the Netherlands since 1950, ReLic 3, ed. Erik Sengers (Hilversum: Verloren, 2005). Also (in Dutch) Joep de Hart, Maak het nieuw. Over religieuze ontwikkelingen en de positie van de kerken. Een persoonlijke geschiedenis (Den Haag: The Netherlands Institute for Social Research, 2011) (inaugural address Protestant Theological University); Paul Post, "Heilige velden. Panorama van ritueel-religieuze presenties in het publieke domein", Tijdschrift voor Religie, Recht en Beleid 1, no. 3 (2010), 70-91; Erik Borgman, Metamorfosen. Over religie en moderne cultuur (Kampen: Klement Pelckmans, 2006); Van de Donk, Geloven in het publieke domein; Willem Frijhoff, Heiligen, idolen, iconen (Nijmegen: SUN, 1998), 35-38 (inaugural address vu University Amsterdam).

3 De Hart, Geloven binnen en buiten verband, 5 .

4 De Hart and Van Houwelingen, Christenen in Nederland, 40-41. 
merger of the two main Reformed churches of the country together with the Lutheran church, into a single Protestant Church is a striking example of the concentration to which we refer. Christianity in general has lost ground and, accordingly, church attendance has significantly decreased. ${ }^{5}$ This pattern is not typically Dutch in nature, other Western-European countries show similar developments, as does the United States. ${ }^{6}$

Yet, this downward movement of institutionalised Christianity does not automatically signify that the Dutch have all become atheists, although agnostics now form the largest group when it comes to the worldviews held by the population. ${ }^{7}$ Rather, as historian Peter van Rooden put it, Christianity simply became irrelevant due to the rise of a 'reflexive and expressive self'. What remains is apparently a 'basic sacral' ${ }^{9}$ attitude and behaviour, whilst a new group of unaffiliated 'floating believers' has also arisen. ${ }^{10}$ The number belonging to this group of 'floating believers', however, in no way outweighs the decline of established religion. This 'basic sacral' attitude and behaviour is lived out and performed in several different domains, as Paul Post observes. ${ }^{11}$ Firstly, it is performed in the private domain - for instance by means of profane altars and memorial corners in private homes, or home rituals around birthday parties or childbirth. ${ }^{12}$ Secondly, it is played out in the public domain - think of the flowers and improvised crosses which mark the location where someone died in an accident - but also of the 'casual sacrality' found in suburbs at places where art, history, and nature emerge as places

In the last ten years in both the Roman-Catholic Church and the Protestant Church in the Netherlands, church attendance has decreased by more than $35 \%$. "Kerncijfers", KASKI Radboud Universiteit, http://www.ru.nl/kaski/onderzoek/cijfers-overige/virtuele _map/kerncijfers-2012/. Last accessed May 10, 2020.

6 The Pew Research Center, for instance, states that the same trend is seen in the USA. Cf. Pew Research Center, America's Changing Religious Landscape.

7 Bernts and Berghuijs, God in Nederland 1966-2015, 64-65. More on changes in (Christian) religion and worldviews in Chapter 3 .

8 Peter van Rooden, "Oral History en het vreemde sterven van het Nederlandse christendom" [Oral History and the Strange Death of Dutch Christendom], Bijdragen en Mededelingen betreffende de geschiedenis der Nederlanden 119 (2004), 524-551, 547f. Goedroen Juchtmans, Rituelen thuis: van christelijk tot basaal sacraal. Een exploratieve studie naar huisrituelen in de Tilburgse nieuwbouwwijk De Reeshof, Netherlands Studies in Ritual and Liturgy 8 (Groningen/Tilburg: Instituut voor Liturgiewetenschap/Instituut voor Rituele en Liturgische Studies, 2008), especially 306-316 and 379-386.

10 Cf. De Hart and Dekker, "Floating Believers", 71-79.

11 Post, "Heilige velden".

12 Juchtmans, Rituelen thuis. 
with special meaning. ${ }^{13}$ Thirdly, it exists also in the cultural domain - in the numerous performances of Bach's St. Matthew's Passion which take place every year, as well as the passion that I use as a case in this book, but also in literature, movies, and art exhibitions in museums and galleries. ${ }^{14}$ Fourthly, a 'basic sacral' attitude and behaviour occurs in the domain of nature, for example in a spiritual centre within natural nature reserves, or in gardening. ${ }^{15}$ And lastly, it can be found in the domain of health and healing: practices of yoga, sports, wellness, etc. serve as examples here, and the international cosmetics brand Rituals, for instance, saw and successfully exploited this niche.

In summary, we can agree with Peter van Rooden, in saying that "Christendom has collapsed in the Netherlands". ${ }^{16}$ We need to add, however, that religion - and even Christian religion - has remained, but has taken a completely different form. Christian religion has been transferred - moved to another place $^{17}$ - from the institutionalised ecclesial domain to several other domains in the wider culture. This transfer has gone hand in hand with the transformation of Christianity into a less specific religion with Christian elements or roots, it has undergone a marked change in form or appearance. ${ }^{18}$ The boundaries of churches are permeable; religion can no longer be measured by facts

13 Inez Schippers, Sacred places in the suburbs. Casual sacrality in the Dutch VINEX-district Leidsche Rijn, Netherlands Studies in Ritual and Liturgy 16 (Groningen/Amsterdam: Institute for Christian Cultural Heritage/Institute for Ritual and Liturgical Studies, 2015).

14 For research on basic-sacrality in music cf. Mirella Klomp, "Die "Passion-zum mitsingen". Christliche Musik im öffentlichen Raum”, in IAH Bulletin 41 (2013), 97-110 [published in 2015]; Martin Hoondert, "The Interpretation and Experience of the Requiem in Contemporary Culture", Yearbook for Ritual and Liturgical Studies 31 (2015), 133-147; Lieke Wijnia and Mirella Klomp, "Tarenskeen's LUTHER. Allowing for New Forms of Sacrality", Yearbook for Liturgical and Ritual Studies 30 (2014), 243-259. On literature see for instance Rein Brouwer, "Theology, Perhaps. A Practical Theological Reflection on Kristien Hemmerechts' Novel The Woman Who Fed the Dogs", International Journal of Public Theology 9, no. 4 (2015), 428-445.

15 Cf. Ruard Ganzevoort and Johan Roeland, "Lived religion: The praxis of practical theology", International Journal of Practical Theology 18, no. 1 (2014), 1-11. DOI: 10.1515/ijpt-2014 -ooo7; and again Schippers, Sacred Places, esp. 107-143.

16 Van Rooden, "Oral History".

17 Definition of "Transfer". Oxford Dictionary. https://www.lexico.com/en/definition/ transfer. Noun, meaning 1. Last accessed May 10, 2020. In the transfer of large musical forms, this act of moving is initiated by composers, conductors, or directors of music ensembles, among others.

18 Definition of "Transformation". Oxford Dictionary. https://www.lexico.com/en/ definition/transformation. Noun, meaning 1. Last accessed May 10, 2020. With the transfer of a musical form to another context, this form becomes the subject of creative appropriation, i.e. transformation. To avoid misunderstandings of the concepts, we here 
and figures on 'traditional' practices such as church attendance, but has become fluid. 'Liquid modernity' calls forth a 'liquid church.'. ${ }^{19}$ This transfer of religion to the 'extra-ecclesial' domain is part of a broader cultural development: in liquid societies, change and flexibility have generally taken the place of continuity and stability, as well-known sociologist Zygmunt Bauman has extensively argued. ${ }^{20}$ In such societies, religion too has become more flexible and fluid.

It should be noted that such evolution inevitably causes counter movements: instability evokes a desire for stability, fluid religiosity calls forth resistance identities that draw clear boundaries, flows of meaning produce counter movements of 'refundamentalisation', particularly among young church members, who tend to be more orthodox than older generations. ${ }^{21}$ Individuals often respond by clinging more firmly to fixed and shared convictions and beliefs. ${ }^{22}$ Late-modernity is driven by ambivalent forces of globalisation and particularisation, connectedness and rootedness. ${ }^{23}$

\section{Transfer and Transformations of Passion Practices}

The Passion is a good illustration of the broader trend by which Christian religious language, forms, practices and ritual repertoires are on the move to

would like to indicate that we do not use the concept 'transformation' in the sense of music having a transformative power (often also referred to as a 'transporting' power). Although music may certainly bring about changes, particularly within people involved in making or listening to music, and although this may be one of the meanings attributed to the music as it is performed, we do not intend to focus on the transformative aspect of music itself. Transformation, as we use the concept in this article, has music itself as its object.

19 Cf. Zygmunt Bauman, Liquid Modernity (Cambridge: Polity, 20oo); Pete Ward, Liquid Church (Carlisle: Paternoster Press, 2002).

20 'Ecclesial' in this chapter is taken in the sense of 'institutionalised church'. By no means do we intend to confine ecclesia to institutionalised churches - we are well aware of and agree with Martin Luther's basic axiom 'ubi verbum ibi ecclesia' (cf. Martin Luther, D. Martin Luther's Werke, Weimarer Ausgabe 40 (Weimar: Boehlau, 1911), 21-23) - but we mean instead to refer to a realm where institutionalised churches shape their own practices, or their use of objects or symbols for that matter. The practices that we describe and refer to in this article are practices in which institutionalised churches have no say because these take place in the cultural or public or 'outer-ecclesial' domain.

21 De Hart, Geloven binnen en buiten verband, 84-86; De Hart and Van Houwelingen, Christenen in Nederland, 58-59.

22 Barnard c.s. call this 'resistance identity' in Barnard, Cilliers, Wepener, Worship in the Network Culture, 13; 74-76.

23 Barnard, Cilliers, Wepener, Worship in the Network Culture, 1. 
'outer-ecclesial' domains. Although the Passion is first and foremost a practice, a brief look at the history of Passion practices and how these have influenced the Passion as a musical form or play, from distant antecedents to its contemporary transfers and transformations, is worthwhile. This makes it clear that current practices stand in a long tradition within the Christian religion. It is worthwhile to look into how these practices have developed over time, and the ways in which they have influenced what Passions have sounded (and looked) like.

Performances of the Passion originate from the recitation of specific Bible passages on the life, suffering and death of Christ that particularly occurred during Holy Week. ${ }^{24}$ From the $5^{\text {th }}$ century onwards, these Lessons resounded within the liturgy. A characteristic feature of this practice of recitation is that texts are divided into indirect and direct speech: the performance is a narrative which, at times, alternates with quotations. Both Passion practices themselves and the meaning that they have taken on have changed over time and have differed depending on the context. The pilgrim Etheria (also known as Aegeria) in the 4 th century reported that during Holy Week in Jerusalem the reading of the Passion played a significant part in liturgy. This practice was an act of memoria, meant to call to remembrance what happened to Christ, and was participated in with strong commitment. ${ }^{25}$ Around the same time (in the 4th and 5 th centuries) in the West, performances of Passions had another meaning. To St. Augustine, for instance, reading the Passion meant more than simply remembering: it consisted instead of doctrina and contemplatio, which required both solemn reading and solemn celebration. ${ }^{26}$ This brought about a kind of 'objectified performance': the text was recited with an intonation, and became a simple recitative that was not intended to invoke compassion, but proclaimed an act of God-willed suffering, intended to reconcile and liberate the people. Almost a millennium later, in the 13th and 14th centuries, Christ's suffering on the cross began to take greater prominence in Passion practices. As well as performed doctrine, the Passion also became a performance of compassio. ${ }^{27}$ This development in theology and devotion musically resulted in more-dramatic

\footnotetext{
24 This subsection largely draws on Kurt von Fischer, Die Passion. Musik zwischen Kunst und Kirche (Kassel 1997).

25 Von Fischer, Die Passion, 14.

26 Von Fischer, Die Passion, 14. St. Augustin in sermon 218 writes: "Passio Domini et Salvatoris nostri Iesu Christi (...) sollemniter legitur sollemniter celebratur”. Text from H.R. Drobner, Augustinus von Hippo. Predigten zum Österlichen Triduum (Sermones 218-229/D). Einleitung, Text, Übersetzung und Anmerkungen, Patrologia, Beiträge zum Studium der Kirchenväter 16 (Frankfurt am Main: Lang, 2006), 124.

Von Fischer, Die Passion, 23-26.
} 
Passion performances as the sung Passion increasingly took on the form of theatrical performances by several people, and - in Germany, England, Italy and Spain from 1470 onwards - polyphony was employed. ${ }^{28}$ Thus the Passion performances of the late 15th century, but more-particularly those of the 16th and 17 th centuries increasingly became performances of imitatio of and sometimes even identificatio with the suffering of Christ. A more intensive religious piety of the people, with a strong focus on the individual and their relation to Christ resulted in a longing to see and hear more, and to do so with greater intensity. ${ }^{29}$ There was greater desire for the actualisation of the Passion and for making it into a reality. The Passion oratorio as musical form thus came into being: a large choral work, consisting of newly composed recitatives (sometimes akin to Gregorian motives), of inserted chorales and non-biblical texts (arias and ariosi) and extensive opening and final parts. Performances of the Passion came to stand for com-passion with an eye to one's own, individual redemption. ${ }^{30}$ The most famous examples of Passion oratorios are, of course, J.S. Bach's St John Passion and St Matthew Passion, which were explicitly intended to be performed in liturgical settings. In 1766, the Lutheran church of Leipzig decided that the Passion narrative should be read in the liturgy, alternating with congregational singing of Passion chorales. ${ }^{31}$ Soon, other cities followed, whilst the Roman Catholic Church retained the age-old tradition of singing a Latin responsorial Passion. Felix Mendelssohn Bartholdy in 1829 was responsible for the rediscovery of Bach's St Matthew Passion. ${ }^{32}$ This performance consisted of a St Matthew Passion that was shortened and cut to half of its original length (so: transformed), an alteration which went hand in hand with a transfer to a new context: performances became part of a charity concert in the concert hall of the Berlin Sing-Akademie. This became an early example of the transfer and transformation of Passion practices, from liturgy and church to concert and concert hall.

In the 2oth century, Passion performances in concert halls became very popular, becoming fully-fledged cultural phenomena, particularly in the

28 Different roles already start occurring in the 1oth/11th centuries, with the development of several lectio tones in Gregorian chant: one for the chronista (the narrator, reciting in indirect speech using the middle register of his voice, thus expressing moderation and objectivity); one for Christus (this part is sung in direct speech and a lower voice symbolising humility), and one for the turbae/synagoga (the crowd, performing in a high voice, thus symbolising the rage of the people).

29 Von Fischer, Die Passion, 26-30.

$30 \quad$ Von Fischer, Die Passion, 79-8o.

31 Von Fischer, Die Passion, 112.

32 Von Fischer, Die Passion, 113-114. 
Netherlands, where, in the same period, the religious landscape began to undergo significant changes, as we elaborated above. Still, the number of newly composed Passions in this period was relatively small, with three potential causes: 1) modern passion music often had a religious (and from the perspective of the arts: restrictive) character, a fact which is related to the way in which the core doctrines of the Christian faith are brought into the discussion; 2) for this reason, Passion music long remained anchored to the Easter period and, therefore, was also dependent on a somewhat limited time-period with the annual calendar; 3) the fascination for Bach's Passions was (and is) unique, a fact which has notably limited the room for new compositions. ${ }^{33}$

The 21st century so far has shown an apparent revival of the Passion form, and, as a consequence, a great variety of Passion performances. To commemorate the 25oth anniversary of J.S. Bach's death in 2000, the Internationale Bach-akademie Stuttgart commissioned Wolfgang Rihm, Osvaldo Golijov, Sofia Gubaidulina and Tan Dun to compose new settings of the narrative for the Passion 2000 project, with each composer choosing one of the four gospels to set. ${ }^{34}$ This resulted in performances of four very different passions, with each composer transforming the passion in their own particular ways. ${ }^{35}$ Passion 2000 may have been an initiative that took away some of the limitations experienced by composers who have often, in the words of composer James MacMillan, "felt Bach hovering over their shoulders". ${ }^{36}$ Whatever the reason, the emergence of many new passion compositions emerged in the first two decades of this century is now a fact. ${ }^{37}$ In the performances of these,

33 Cf. Johan Snel in Marcel Barnard and Gerda van der Haar (eds.), De Bijbel Cultureel. De Bijbel in de kunsten van de twintigste eeuw (Zoetermeer: Boekencentrum, 2010), 530.

34 Billboard, "Score: New Passions", 17. September 29, 2001, https://bit.ly/2q47ybJ. Last accessed May 10, 2020.

35 See the interview with Helmut Rilling in Billboard for details on these transformations. For the Passion 2000 project, cf. Andrew Shenton, "For whom the bells toll. Arvo Part's Passio, metamodemism and the appealing promise of tintinnabulation", in Contemporary Music and Spirituality, eds. Robert Sholl and Sander van Maas (Oxford/New York: Routledge, 2017), 17-36. Also cf. Joanna Cieślik-Klauza, "Passion Music at the Turn of the XX and XXI Centuries, Part I: Sofia Gubaidulina and Wolfgang Rihm", Rocznik Teologii Katolickiej 17, no. 1 (2018), 183-194; Joanna Cieślik-Klauza, "Passion Music at the Turn of the XX and XXI Centuries, Part II: Tan Dun and Osvaldo Golijov", Rocznik Teologii Katolickiej 17, no. 3 (2018), 107-117.

36 Fieldnotes taken on March 18, 2011 during a 'meet the artist'-session with James MacMillan prior to the concert of his St. John Passion in Flagey, Brussels.

37 A somewhat random list of examples: 'St. John Passion' by Gubaidulina (2000), 'DEUS PASSUS (St. Luke Passion)' by Rihm (2000), 'La Pasión según San Marcos' by Golijov (2000), 'Water Passion after St. Matthew' by Dun (2000) - all four part of the Passion 
transformations vary significantly from Jesus Christ as the main character being replaced with a woman whose salvation requires the fall of the entire cosmos (Utopia47:: a very last Passion) on the one hand, to performances of the libretto of the fairy-tale of the little match girl who freezes to death on another, with the match girl's suffering over the course of the passion increasingly coinciding with the suffering of Jesus Christ on the cross, musically symbolised by the insertion of fragments from Bach's St Matthew Passion (Little Match Girl Passion). This great diversity within contemporary appropriations of the passion makes it difficult, if not impossible, to describe a 'general meaning' for Passion practices in the 2oth and particularly the 21st century. This is related to at least two factors: first, compositions that are performed more and more follow from the personal motivations and interests of their composers, which vary between different social, political and religious situations; second, people (composers, performers, and concertgoers alike) increasingly decide for themselves what things mean: they all attribute meaning (including religious meaning) according to their own collection of interpretive frames (see Chapter 7). The way in which religious immaterial heritage such as Christian rituals or, as in our case, a large musical form, is experienced and obtains meaning is affected by the tendency towards individuality that is part of modernity: people deal with these things in their own individual ways, even when the ritual is performed collectively (see Chapters 5 and 7 ).

As has now been demonstrated, Passion practices and their meanings have changed over time and have differed depending on the context. If indeed the transfer and transformation of Christian music practices was already underway in the 19th century, how should we account for the difference of the current situation compared to the past? The key phrase here is 'a changed religious landscape'. For almost a millennium and a half, passions in the Western world were performed in a culture dominated by Christianity. Over the past few centuries, the dominance of Christian faith has gradually changed, but the biggest shift occurred in the 2oth century (in the Netherlands this was particularly linked with the end of pillarisation in the 196os, see Chapter 5). So, today, processes of transfer and transformation surrounding performances of

20oo-project. Afterwards 'Mattheuspassie, een lezing voor 19 zangers' by Tarenskeen (2006), 'Lucas Passie' by Tsoupaki (2007), 'Little Match Girl Passion' by Lang (2008), 'Passio Compassio' by Ensemble Sarband (2010), 'Judas Passion' by Egon Kracht \& The Troupe (2010), 'Utopia47:: a very last Passion' by Blindman/Sleichim (2011), 'St John Passion' (2012) and 'St Luke Passion' (2014) by James MacMillan, 'The Gospel according to the other Mary' by Adams (2013), 'Nasimi Passion' by Franghiz Al-Zadeh (2017). 
the Passion (and of any religious form, language and repertoire for that matter) take place in a culture that generally no longer identifies itself as Christian. This deeply affects the transformations of these musical practices. It also deeply affects the meanings people attribute to passions performed on stage.

Today, most Dutch people sleep in on Sunday morning and never go to church, yet every year on Maundy Thursday, a few million people, in their leisure time participate in this popular show that is based on a Christian narrative. The producer and broadcasting companies have transferred the annual ritual performance of the passion from the liturgy to the city square and transformed it into a media event. The 'lightness' which characterises this passion has given it the nickname of the 'showbiz-passion'. Its process of transformation has hardly touched the narrative (this is still based on the gospels, contrary to transformations in other passion compositions), but lies in its fluidity and link with liquid modernity: in Chapter 1, we indicated that The Passion has a rather fixed format alongside many fluid aspects (music, location, audience, performers, (theological) meaning, motto), which make it an ever-changing dynamic ritual event.

Two misunderstandings might arise here, which may be good to address. The first: that the idea of transformation suggests that there is (or ever was) an original - an absolute point of reference, a central passion form from which all other forms have been derived. There is of course none: even the gospels pass on the narrative of what happened to Jesus Christ in four (more or less) different versions. As we have already mentioned, the Passion is a practice rather than a 'thing', and this means that no two Passions are ever the same. Transformation may be a helpful notion, but only in close connection with the notion of transfer which points to changes relating to performances in a different context than in the past.

The second misunderstanding - the idea that transfer and transformation of the passion is a unidirectional process from church to the broader culture seemingly contradicts the first, but actually points to a paradox. The transformation that comes with the transfer does not necessarily 'stay' in the broader the culture: such a process would be static, rather than dynamic and fluid. Rather, new practices themselves may, like a pendulum, cause other transformations. A very specific example of this is the way in which The Passion, a practice that is itself a result of the transfer to the 'secular' public domain, has in turn changed the liturgical practice of the church. As mentioned in the previous chapter, several parishes and congregations over recent years have embraced The Passion: they have seen the passion narrative performed in a way they could have never invented or executed on their own and, acknowledging its success, they have brought the passion narrative in this new form 
(back in)to the church, either by putting up large screens in the church building to enable people to watch it together via live stream, ${ }^{38}$ or by taking the format of The Passion as an example to create their own local version of The Passion, with local narrators, singers, bands and celebrities. ${ }^{39}$ Either way, The Passion has inhabited various different spaces in the (liturgical) life of the congregations involved. The Passion sometimes serves as a 'ritual supply' complementary to worship, sometimes as a substitute for traditional liturgy. ${ }^{40}$ In other cases, a local Passion has been inserted into the liturgy (for instance in vespers during Holy Week). ${ }^{41}$ In the case of local Passions, parishes have often sought partners for collaboration: with other parishes, but also with primary and/or high schools. Occasionally, Passions have been advertised as an event especially for youth.

In summary, the case of The Passion nicely demonstrates the oscillation of ritual practices and repertoires between the domain of institutionalised churches and the broader culture. It shows how practices that are deeply rooted in and connected with Christianity have changed over time, now taking the form, among other things, of a highly fluid ritual-musical practice. Its particularity lies in its strong connection with both popular culture and liquid modernity: as soon as religion disentangles itself from the bastions of institu-

38 In 2015, this was done in various churches in Enschede, but also throughout the country, e.g. Renkum/Heelsum, Leiderdorp, Berkel en Rodenrijs. Sources: EO/Kro, "Activiteiten", http://www.thepassion.nl/activiteiten. Last accessed August 15, 2016, and "Passions door het hele land", March 30, 2015. Protestantse Kerk in Nederland. http://www.protestantsekerk.nl/actueel/Nieuws/nieuwsoverzicht/Paginas/ Passions-door-het-hele-land.aspx. Last accessed October 30, 2019.

39 "Passions door het hele land", Protestantse Kerk in Nederland. The aim in the case of local versions of The Passion often seems to have shifted compared to the 'original' that aimed to familiarize a broad public with the passion narrative. Locally, the aspects of building the congregation and inviting conversion to Christ become more important. This might explain why quality (of sound, light, performance, etcetera) is sometimes considered of lesser importance. Source: conversation with two groups of Protestant ministers who followed the course "Re-staging the Passion. The Passion Narrative in the Arts", taught by the authors of this chapter at the Protestant Theological University in Groningen and Amsterdam, January-February 2016.

$40 \quad$ In Wijk bij Duurstede in 2015, 'The Passion of Christ' replaced evening prayer in the Protestant Church of Cothen on Tuesday in Holy Week. Source: Rebecca Onderstal (@rebeccaond), Twitter, April 22, 2015, o6:oo p.m., http://twitter.com/rebeccaond. In the Protestant Noorderkerk in Zaandam, there were no traditional services on Wednesday and Maundy Thursday because of their 'PassionZaandam'. Source: Sjaak Visser, e-mail message to MK, April 23, 2015.

41 This was the case in the Protestant congregation of the village Eerbeek. Source: "Passions door het hele land", Protestantse Kerk in Nederland. 
tional religiosity and moves to the squares and market places of late-modern 'secular' society, it immediately becomes influenced by e.g. new forms of commercialisation, visual culture, fandom culture, and media portrayals of contemporary trends. The Passion is not the only example of this transfer and transformation, and we have already discussed other ritual-musical transformations of the Passion. A number of musical examples serve to illustrate this phenomenon more broadly. The rise of Contemporary Christian Music (ссм, or 'relipop' in Dutch), for example, has developed as a full branch of the commercial music industry. In the Netherlands this has been stimulated, in particular, by broadcasting company EO, which has not refrained from using modern means to communicate the gospel. ${ }^{42}$ Festivals of classical, pop and rock music likewise seem to have become a milieu of religious experience. ${ }^{43}$ These can be characterised as examples of the shift from a 'spirituality of dwelling' to a 'spirituality of seeking' to use the sociological terms of Robert Wuthnow. ${ }^{44}$

\section{The Sonic Aspects of Religion}

So far, in sketching the scenery of The Passion, we have described the changing Dutch religious landscape, as well as the history, transfer and transformation of the passion as a musical form and play. The question arises as to how we can theoretically understand fluid religious musical practices such as The Passion. What theoretical concepts can be applied to deepen our understanding of the transition and transformation of large musical forms to 'outer-ecclesial' domains? Searching in the toolboxes of anthropology, religious studies and ethnomusicology, we have found and combined several concepts that we think can be helpful.

42 Since 1974, EO has annually organised the 'EO Youth Day', a large-scale Dutch Christian event that attracts thousands of young people every year. In four decades, this has developed into a an expressive 'hip' event with optimistic biblical one-liners and an evangelical swing. Cf. Johan Roeland et al., "'Can we dance in this place?' Body Practices and Forms of Embodiment in Four Decades of Dutch Evangelical Youth Events", Journal of Contemporary Religion 27, no. 2 (2012), 241-256. DoI: 10.1080/13537903.2012.675736. Also cf. Ronelle Sonnenberg et al., "Shaping Youth Worship. Modes of active participation", Questions Liturgiques 95, no. 3-4 (2014), 216-236.

43 Heleen Kommers, Hidden in music. An approach to religious experience and pop or rock festivals (PhD diss., Tilburg University). Self-published 2013 (ISBN: 978-94-6108-459-o). Lieke Wijnia, "Making Sense Through Music. Perceptions of the Sacred at Festival Musica Sacra Maastricht" (PhD diss., Tilburg School of Humanities, s.l., 2016).

Wuthnow, After Heaven, 3-4. 


\section{Appadurai's Five - Scapes}

When describing the changing Dutch religious landscape, the word landscape does not simply refer to a specific piece of land or even to the country itself but rather to scenery more broadly, that is to say to the 'design and layout of large spaces.' ${ }^{45}$ It includes all elements of such scenery. The Dutch landscape contains the mill, the green meadows, smaller and larger canals, the poplar trees rustling in the wind, and the sky with clouds that sail along like sailing ships; it is the rain and the sunshine, the wind and the water, and the people moving in this landscape. It is a setting, a décor that can never be captured in one notion. The Indian anthropologist Arjun Appadurai has used the suffix -scapes to define five 'cultural dimensions of globalization' that characterize the current world. ${ }^{46}$ The world is an informational society, in which ideas, cultural values, money, and information move through the network at unprecedented speed. In addition, people are also on the move, be it as labour migrants, as refugees, or as tourists. The World Wide Web and the airport are the preeminent icons of this world, multimedia technology, and modern aircraft comprise the material basis underlying it. ${ }^{47}$ Appadurai (already in 1996) has proposed five -scapes: ethnoscapes, mediascapes, technoscapes, finanscapes, and ideoscapes. These are 'five dimensions of global cultural flows. 48 None of these aspects of our current world can be captured completely in one single or simple notion. They all refer to complex, layered, and differentiated phenomena.

\section{McAlister's Religioscapes and Tweed's Sacroscapes}

Scholars of religion Elizabeth McAlister and Thomas Tweed, have both transferred Appadurai's notion of -scapes to religious studies. McAlister speaks of 'religioscapes' as 'the subjective religious maps - and attendant theologies - of immigrant, or diasporic, or transnational communities who are also in global flow and flux'49 Tweed speaks of religions as 'sacroscapes': 'religious flows' 'across time and space' that every now and then come to a temporary standstill here or there. ${ }^{50}$ Both analogies suggest that religions are connected to the local

\footnotetext{
45 J. Coulson, C.T. Carr, and L. Hutchinson, D. Eagle, eds., The Oxford Illustrated Dictionary, 2nd ed. (Oxford: Clarendon Press, 1978).

46 Arjun Appadurai, Modernity at large: Cultural dimensions of globalization, 2nd ed., Public Worlds 1 (Minneapolis: University of Minnesota Press, 1996), esp. 33-43.

47 See Manuel Castells, The Information Age: Economy Society and Culture, 3 vols. (Cambridge: Blackwell, 1996-200o), esp vol. 1, The Rise of the Network Society.

48 Thomas A. Tweed, Crossing and Dwelling. A Theory of Religion (Cambridge, Mass: Harvard University Press, 2006), 61.

49 Elizabeth McAlister, "Globalization and the Religious Production of Space", Journal for the Scientific Study of Religion 44, no. 3 (2005), 249-255, here 251.

Tweed, Crossing and Dwelling, 6if.
} 
as well as to global space and time. Neither Appadurai nor Tweed or McAlister use narrow definitions in their work, which is related to their approach of the subject of study. Scholars of religion and theology move through a landscape, across a field - in their case the field of religion - and as a consequence their theory is dynamic as well, Tweed claims:

Theory as embodied travel is not a stationary view of static terrain. It is not geography or chorography (...). Theory is purposeful wandering. (...) A theory of religion, as I understand, is not an omnispective map of the whole offered by a stationary observer. Theory is travel..$^{51}$

He adds that his notion of sacroscape 'only helps if we have aquatic and nonterrestrial analogies in mind. Sacroscapes (...) are not static. They are not fixed, built environments - as the illusion to landscape in the term might imply $(\ldots)^{\prime} \cdot 52$

We propose that the passion and other large ecclesial musical forms that have moved to the 'outer-ecclesial' domain can be understood within the frameworks that Appadurai, McAlister, and Tweed have built. The particular notion of sacro-soundscapes then naturally comes to the fore.

\section{Soundscapes in Acoustemology and Theology}

The concept of the 'soundscape' has been present in scholarly debates since the 1950s and finds its origin in the fields of culture and technology, music studies, and anthropological and ethnomusicological studies of 'acoustemology'.53 The musicological and anthropological notions of 'soundscape' appear to be those which are most relevant to explorations of religious experience and its sensual mediation, and the work of Steven Feld, professor of anthropology and music at the University of New Mexico, must be mentioned at this point. ${ }^{54}$ Feld's work has been described as 'a refined analysis of auditory space as a complex field of meanings that is closely related to spiritual and religious practices, to cosmology, and to a conceptual ordering of the world through material objects, practices, and social organization., ${ }^{55}$

\footnotetext{
$5^{1} \quad$ Tweed, Crossing and Dwelling, nff.

52 Tweed, Crossing and Dwelling, 61.

53 Dorothea E. Schulz, "Soundscape", in Key Words in Religion, Media and Culture, ed. David Morgan (New York: Abingdon, 2008), 176-186.

54 Steven Feld, "Waterfalls of Song: An Acoustemology of Place Resounding in Bosavi, Papua New Guinea", in Senses of Place, eds. Steven Feld and Keith H. Basso (Santa Fe, NM: School of American Research Press, 1996), 91-136.

55 Schulz, "Soundscape", 179.
} 
A focus on sound can also be traced in the discipline of theology. John McClure uses the term soundscape when writing about the invention of religious desire. Mixed and mastered sounds leave the recording studio and become part of a larger soundscape of music within the larger culture. McClure states that 'in large part, this soundscape is made up of music that accompanies us when we work, read, eat, relax, and travel. But this soundscape also includes other forms of media: television, Internet, podcasts, and so on, as well as the sounds of city and rural life, including automobiles, machinery, airplanes... ${ }^{56}$ Soundscape, McClure suggests, quoting aesthetic philosopher Gernot Böhme, is the ability to hear the 'musicality of the world itself': 'the feeling of 'home' is strongly mediated by the soundscape of a region, and the characteristic experience of a lifestyle, of the atmosphere of a city or area of countryside, is fundamentally determined in each instance by its acoustic space. ${ }^{57}$

In The Sound of Worship, a liturgical ethnography that sought to update the concept of 'church music', I came to conclusions similar to those of Feld and McClure, although I did not yet use the concept 'soundscape. 58 In using the broad concept of sound to investigate the sonic aspects of liturgy, instead of the somewhat limited concept of church music, I made clear that sound is 'linked up with performance and movement' and thus with 'embodiment. ${ }^{59}$ I asserted that the sonic practice of worship (which itself is an auditory space) as performed by congregations and parishes is a practice that becomes loaded with religious meanings closely related to cultural contexts and worldviews. Faith in worship is expressed by the performance of sound, while this performance, at the same time, inscribes faith into the bodies of participants.

According to sociocultural anthropologist Dorothea Schulz, Feld takes the notion of '-scape' very seriously when he posits the spatial as the starting place for the exploration of the role of bodily movement and sensual orientation in religious experience and mediation. Schulz subsequently claims that

56 John McClure, Mashup Religion. Pop Music and Theological Invention (Waco, TX: Baylor University Press, 2011), 109-122, here 117.

57 John McClure, Mashup Religion, 118.

$5^{8}$ Klomp, The Sound of Worship, 39.

59 I thank dr. Mark Porter for pointing out to me that the term 'church music' means very different things in different countries. Kirchenmusik in Germany tends to be a much more restricted and hierarchical phenomenon than church music in the UK. The study of kerkmuziek in the Netherlands long relied on a German understanding of the phenomenon, using German-language literature. I am referring to these 'limited' understandings of the concept here. 
because soundscape is closely related to body movement and sensation and anchors religious experience in the here-and-now, it implies a notion of localized 'scape' that differs from de-territorialized conceptualizations of 'scape', such as reflected in Appadurai's famous 'ethnoscape'.60

Schulz tends to see the notions of localised scapes and de-territorialised conceptualisations of scape in opposition. With Tweed, who speaks about crossing and dwelling, we, however, consider the two as inextricably connected, as we will now demonstrate.

\section{Sacro-Soundscapes}

In connection with Tweed's 'sacroscapes' and the use of 'soundscapes' in music-related studies, we propose the notion of 'sacro-soundscapes' to point to the sonic aspects of religions. These are understood as being in a state of constant flux, in a permanent flow, but also as 'dwelling' intermittently and at irregular times. ${ }^{61}$ The notion of 'sacro-soundscapes' refers to the movements of sacred sound through times and spaces. ${ }^{62}$ Psalms, hymns, spiritual songs, religious pop music, and large musical forms that stem from the Christian tradition (such as Masses, Requiems, Stabat Mater's and Passions) move across time and space: they originate in a specific place and time and move alongside the people who sing the songs, the musicians who play the music, and the customers who buy and/or download the music, and they find temporary dwellings, for example in hymnals, in the seasonal programs of choirs and orchestras, or in an event such as The Passion. Individual people, groups of friends or colleagues, congregations and parishes, and the crowds of people who attend festivals and events carry these various sounds along with them, cherish them, discuss them, reject them, leave them behind, and/or find them again. This whole complex of sacred sounds, their words and music, the way they are performed and accompanied, the context in which they are performed, the way they are appropriated, and the attributed meanings that peo-

\footnotetext{
6o Schulz, "Soundscape", 185 .

61 Cf. Castells, The Information Age, especially vol. 1, The Rise of the Network Society; Bauman, Liquid Modernity; Barnard, Cilliers and Wepener, Worship in the Network Culture.

62 So far we have spoken about 'ritual musical practices'. Our focus on sound (vs. music) here emphasizes that we do not limit people's sonic practices to the particular shape of music alone: a fixed focus on the particular shape of music would be inappropriate when developing a concept for the interpretation of fluid practices.
} 


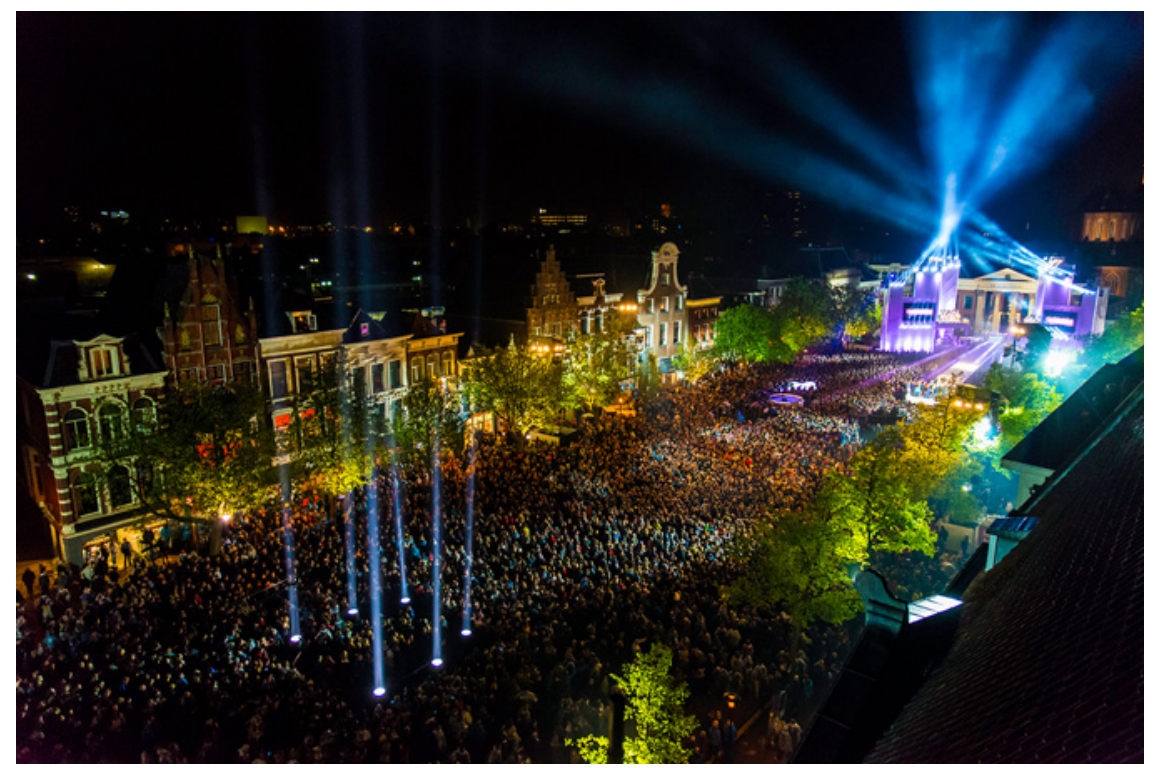

FIGURE 5 The temporary dwelling of a passion performed on the Grote Markt in the city of Groningen in 2014

PHOTO: WILLEM-JAN DE BRUIN

ple share, create a sacro-soundscape. ${ }^{63}$ In the particular case of The Passion, the 'secular' top hits placed within the framework of the passion narrative are loaded with new and sacred meanings, and make The Passion a temporary dwelling for a selected number of songs, a station, and a significant landmark in this soundscape. ${ }^{64}$ The changing and liquidising sacro-soundscape (de-territorialised -scape) became 'grounded' in the temporary dwellings of a passion performed in the city of Gouda in 2011, of Rotterdam in 2012, of Den

63 We develop the notion of the 'sacro-soundscape' in this chapter in order to refer to the transfer and transformations of practices of religious musical forms and repertoire. We do not use the concept in order to claim that musical forms from the Christian tradition automatically become sacred (cf. the next footnote), nor do we intend to limit sacrality to religious forms, as any practice or object can become the object of sacred meaning making.

64 Sacred meaning-making here is taken in a broad sense, based on an approach that looks beyond a divine presence in the direction of an actively constructed value within a particular meaning system, from which people in turn mix and match elements to their own convenience and liking. This is further elaborated in Wijnia and Klomp, "Tarenskeen's LUTHER". 
Haag in 2013 and so forth (localised scape). So, elements of a sacro-soundscape (repertoire, musical forms, psalms and hymns, etc.) travel across domains and find temporary local dwellings that anchor religious experience in the hereand-now.

\section{The Study of Sacro-Soundscapes}

One consequence of the development of Dutch society - and presumably of other Western societies - beyond the church, beyond institutionalised religion, and possibly even beyond religion, is that our universities and faculties are now developing into institutions that move beyond theology and, at the same time, also beyond religious studies. That does not mean that religion is no longer studied, but rather that theology and religious studies have become part of larger research consortia, or at least have moved closer to the humanities. As a consequence, we have also moved beyond the classical study of sacred sound: hymnology, which singled out Christian congregational music, whilst leaving all other sacred music to ethnomusicology. ${ }^{65}$

When we consider classical hymnology as part of practical theology or liturgical studies, we must account for the shift that has occurred in these disciplines over the past three decades. We can see that practical theology today in our context is often akin to public theology, whereas liturgical studies are referred to as liturgical ritual studies or is seen as (a part of) ritual studies. Practical theology defines its task mainly as a theological reading of practices of faith in a broad domain, and the inner-ecclesial domain is investigated as part of a

65 At least, in the German- and Dutch-speaking context. The definition of hymnology in the entry on the same subject given by Marcus Jenny, "Hymnologie", in Theologische Realenzyklopaedie, eds. Gerhard Krause and Gerhard Müller (Berlin: De Gruyter, 1986), 15: $770-778$, may serve as an example of how the discipline was perceived: as a practical theological discipline, more specifically as part of liturgical studies. According to Jenny, linguistics and musicology are its main supporting disciplines outside theology. More specifically, he defines hymnology as 'the study of Christian hymns in all their forms and expressions and at all times'. It includes the study of hymns and anthems as well as of Gregorian chant. Further it comprises hymnal studies - defined as 'an auxiliary discipline for the editing of hymnals' - church music, theology of church music and the practical training of church musicians. Its object is church hymns and church music, from a fundamental and from a practical perspective, as well as non-strophic, non-metrical and non-rhythmic forms of church music and sung texts. In summary, the focus of hymnology is on church music and texts that are sung in churches and worship services. 
broader field. ${ }^{66} \mathrm{~A}$ sacro-scape has developed that does not respect the boundaries of churches and denominations, but that is highly fluid. ${ }^{67}$ The church is a landmark or a discrete phenomenon in a wide sacro-scape, and it is studied as such. The same holds for liturgical ritual. Many studies have shown that liturgical ritual stands in a dynamic relationship to a liquefied culture. ${ }^{68}$ The topic of liturgical ritual studies now becomes the ritual and symbolic aspects of these sacro-scapes, and the topic for the successor of hymnology becomes the sound aspect of sacro-scapes. In short it researches sacro-soundscapes.

\section{Conclusion}

In this chapter, we have developed a notion of sacro-soundscapes in close connection with the work of cultural anthropologists, ethnomusicologists, historians, theologians, and religious studies scholars. Sacro-soundscapes do not

66 We are aware of discussions, such as those published in the International Journal of Practical Theology 16, no. 1 (2012), on what practical theology actually is. These clearly demonstrate that there is no shared understanding of this discipline. What is presented here is our view of the discipline.

67 Cf. Pete Ward, Participation and Mediation: A Practical Theology for the Liquid Church (London: SCM Press, 2008), where the author claims that in order to make sense of the contemporary nature of the church it is crucial to understand in what way cultural expression mediates that encounter with God.

68 We here mention a couple of relevant research projects on sacro-soundscapes that have been performed in the Netherlands since 20o6. Dr. Martin Hoondert (Tilburg University), in his $\mathrm{PhD}$ thesis Om de parochie. Ritueel-muzikale bewegingen in de marge van de parochie. Gregoriaans, Taizé, Jongerenkoren (Heeswijk: Abdij van Berne, 2006), concludes that the margin of the parish has increasingly developed into a locus for new liturgical and musical initiatives, whereas the core parish has stayed behind by sticking to the old. The sacro-scape has innovative musical qualities, but these are not located in the traditional churches. Hoondert is currently investigating Requiem concerts in Dutch culture and musical repertoires used at funerals, and is supervising a research project by Janieke Bruin-Mollenhorst MA (Tilburg University) on music during cremation rituals. I myself have also investigated the margin as a breeding ground for innovation in a study on the performance of sound in two migrant churches in Amsterdam (Protestant Theological University). My research on the liturgy of immigrant churches has suggested several qualities of sound: notions that refer to the open and fluid, much more than to the strict, closed and denominational. See Klomp, The Sound of Worship. Dr. Hanna Rijken (Protestant Theological University) has studied the popularity of English evensong - as worship or as a concert - in the Netherlands, and its appropriation by visitors, choir members, pastors, and musicians. See Hanna Rijken, "My Soul Doth Magnify'. The Appropriation of the Anglican Choral Evensong in the Netherlands" (PhD thesis Protestant Theological University, Amsterdam, 2017). Dr. Lieke Wijnia has investigated Festival Musica Sacra Maastricht, focusing on experiences of sacrality in contemporary culture through music. See Wijnia, Making Sense. 
respect the boundaries of churches or denominations, but are highly fluid. The concept enables us to better understand musical practices in a liquefied religious landscape, as it takes the fluidity of these practices into account as well as the contexts in which they are performed. Religion in general has become fluid, and so has the study of religious objects and practices, as the changing position of theology and religious studies in academic life shows. In our view, research on these fluid practices calls forth a surpassing of the traditional sub-disciplines of practical theology. Practical theology nowadays largely deals with faith practices within broad sacro-scapes. It has predominantly moved beyond church-centred liturgical, catechetical, congregation$\mathrm{al}$, and pastoral studies. It has moved into the study of sacro-scapes that are approached from symbolic and ritual perspectives, from perspectives of formative or learning processes, of community formation, and of care. Musical theological perspectives have, consequently, also moved beyond hymnology in its classical understanding as their main site.

Our updated and broadened definition of the field of sacred music has consequences for our understanding of the field of study: the 'original' field has changed. From the moment singing became an element inherent to liturgy in the first centuries $\mathrm{CE}$, there has always been something like hymnological reflection. ${ }^{69}$ Christian hymnology, as a result, developed to focus on ecclesial singing, later coming to include the systematic collection of Christian hymnbooks. In 21st century network societies, where performances of large-scale Christian musical forms are no longer confined to churches and congregations, and where the sonic aspects of religions are understood as being in a constant flux and a permanent flow, the field of study is becoming more expansive. The inner-ecclesial domain in this context is to be researched as part of a broader field or, indeed, as part of a sacro-soundscape. This requires openness toward 'extra-ecclesial' musical practices in any field of study that regards practices of Christian music. It requires openness towards fluid musical expressions of religiosity, for instance towards the (more or less ad hoc) groups of people participating in The Passion, in sing-along Messiahs, or in choral evensong concerts. And it requires openness towards musical festivals or events - be it 'Christian' or 'sacred' or based on a particular music style and towards those whose names are not on church membership lists, but who take part in any practice of music and may identify or encounter God or the sacred. If practical theologians want to study religion and new quests for God in a society 'after God', maximum openness is required concerning the practices they choose as their objects of study. In the following chapters, we will see the yield of this broader approach.

69 Jenny, "Hymnologie", 77o. 


\title{
The Re-Appearance of God: Ana-Liturgy
}

\author{
\#iwalkalong special \#thepassion I walk along for my grandson [...] \\ who fights for his life in the IC of UMCG Groningen \\ TWEeT, 17 April 2014
}

\begin{abstract}
After the fireworks explosion in 2000 that destroyed the residential area Roombeek, here in Enschede, there was a huge sense of unity. Today, we have come to The Passion on this large square to experience that same sense of unity.

TWO FEMAle INHABitants OF ENSChede, April 2, 2015

(interview on H.J. van Heek Square, MK)
\end{abstract}

Walking the procession can be a very spiritual experience, I think. Maybe people can leave suffering behind and make a new start. [...] The procession is a sort of spring cleaning.

BRIDGET MAASLAND, procession news reporter at The Passion, 20 March $2015^{1}$

Secularisation in the Netherlands has been qualified in the preceding chapters as the 'receding of Christendom.2 ${ }^{2}$ The two biggest churches (the Protestant

1 During the show, there is live coverage of the procession by a famous TV personality in the role of news reporter. In 2015, dancer, show host, model and animal rights activist Bridget Maasland played this role. The quotation (translation $\mathrm{MK}$ ) is taken from a promotional clip for The Passion 2015. See "Processie is soort grote schoonmaak", EO Visie, March 20, 2015, video. https://visie.eo.nl/2015/o3/processie-is-soort-grote-schoonmaak/. Last accessed May 10, 2020.

2 This chapter is a revision of an article with material presented in two different papers, that was previously published as Mirella Klomp and Danie Veldsman, "After God, But Behind the 
Church in the Netherlands and the Roman-Catholic church) continue to see decreasing membership, the Roman-Catholic church struggles with diminishing vitality, and churches face increasing marginalisation in society. ${ }^{3}$ Christian belief, experiences and practices show a trend of waning theism. The practices of Christian faith have receded in the past five decades, but the recession has intensified in the past ten years, according to the 2016 research report GIN. The report also revealed a strong reduction in a transcendent worldview $(6 \circ \%>$ $42 \%)$ and an increase in agnostic and atheist worldviews (40\% > 58\%) among the Dutch over the past decade. ${ }^{4}$

In the Prologue to this book, I made some critical remarks about methodological approaches which measure religion by the extent to which people subscribe to (a set of) religious beliefs, and the theory of religion that underlies such approaches. It is nevertheless interesting to observe recent developments in the degree to which people subscribe to what the authors of GIN call the 'basic beliefs' of Christianity. ${ }^{5}$ In 2016, fewer people subscribed to the belief that Christ is the son of God or was sent by God (40\% > 28\%) than in 2006; fewer people considered the Bible to be (fully or partly) the Word of God $(51 \%>35 \%)$ while many more people indicated that they did not know $(7 \%>$ $22 \%)$; fewer people believed in some sort of afterlife $(40 \%>23 \%)$, while more people had doubts $(31 \%>37 \%)$ and many more had come not to believe in an afterlife in any form $(29 \%>40 \%) .{ }^{6}$ It seems that people are becoming less able to relate to the beliefs or dogmas that of Christian traditions over the course of time. They are beyond 'traditional' images and ideas of God, and, in the wake of this, let go of God. ${ }^{7}$

Cross. The Procession as a Way to Re-encounter God in a Culture Beyond Classical Liturgy", Studia Liturgica. An International Ecumenical Review for Liturgical Research and Renewal 47, no. 1 (2017), 15-29. In part this chapter is also based on Mirella Klomp, “The Passion' met God als optie", Kerk en Theologie 66, no. 2 (2015), 134-140. I want to express my gratitude to my colleague and friend Danie Veldsman with whom I extensively discussed the work of Kearney in relation to the case of The Passion, and who provided valuable feedback on my paper presentations and the text.

3 Bernts and Berghuijs, God in Nederland 1966-2015, 30-31.

4 Bernts and Berghuijs, God in Nederland 1966-2015, 64-65. The report used the following classification: theists are people who believe in a God who is personally involved in the life of every human being, somethingists are those who believe in a higher power that controls peoples' lives, agnostics are those who do not know whether or not there is a God and/or higher power, and atheists are people who do not believe in a God or higher power.

5 Bernts and Berghuijs, God in Nederland 1966-2015, 66.

6 Bernts and Berghuijs, God in Nederland 1966-2015, 64-72.

7 The word 'traditional' is not unproblematic as, in the context of religion, it often has connotations of old-fashioned and orthodox. However, I do not use it in a pejorative sense, 
In the Prologue, I identified the paradox that a contemporary multi-media event, based on the religious narrative of the suffering and death of Jesus Christ, has become so popular in a 'secularised' country. One element that has been part of The Passion from the very beginning and which has expanded over the course of subsequent editions demonstrates this paradox in a poignant manner: the procession with a large, neon lit white cross. In a society 'after God', over a hundred thousand people gather 'behind the cross'. The research report GIN makes clear that people have not made a large-scale return to 'traditional' Christian belief. But although they may not actively seek God, the popularity of The Passion raises the suspicion that there is at least some kind of openness towards elements of Christian heritage or Christian repertoire. This raises the question of whether it is possible that people return to God after God, in a way different from the past. Can we speak about God after God, and if so, how?

In this chapter, I use the qualitative research data that I collected on the procession of The Passion to investigate how, in the various forms of the procession ritual, God may come up and may be encountered. As a theologian, I identify the key issue as the sacramental quality of late-modern Christian repertoire, more specifically, the encounter with God through, with, and in rituals. The experience of many people in 21st century Western European societies, that Christianity has become unbelievable, calls for the further development of 'theology after the death of God'. This chapter aims to contribute to this development by theologically exploring how God could be encountered in the procession practices of The Passion.

Those taking part in the procession - even those whose stories I tell in this chapter - may well not endorse my theological interpretation, or may even emphatically object to it, largely because they themselves do not explicitly interpret the procession as a sacred or religious practice. This directly touches on what Tone Stangeland Kaufland has termed a practical theological conundrum: the relationship between normative and descriptive dimensions in practical theological work. Giving an overview of various possible relationships, Kaufland has presented a grid of practical theological positions. ${ }^{8}$ I position my effort to understand the return of God after God in this chapter as, what she calls, a practice-oriented approach, where no voice is given primacy

but literally: images of God have taken shape as Christian tradition has developed over the course of time.

8 Tone Stangeland Kaufman, "From the outside, within, or in between?" in Conundrums in Practical Theology, Theology in Practice 2, eds. Joyce Ann Mercer and Bonnie MillerMcLemore (Leiden/Boston: Brill, 2016), 134-162, esp. 139. 
in advance: "Here human experience and the practice encountered in the empirical field studied are granted the position of possibly revising or reshaping the received tradition. (...) Neither normative dimensions nor "the theological" can be nicely located or placed in any one of the steps of a practicetheology-practice model (...). Rather, these dimensions are embedded in the entire practical theological undertaking or the practice of practical theology". 9 Empirical data on the procession shows that participants have many different interpretations of the procession activity, and some of these interpretations are explicitly informed by 'traditional' Christian dogmas. ${ }^{10}$ Yet, these do not work for those in the procession who are 'beyond God' (as the research report GIN showed). This calls for new theological explorations of how, in these practices, God may be encountered. The warrant for this undertaking lies in people's openness toward this late-modern procession, which is expressed by their participation in it. The investigation of the possibility for encountering God is inherent to the radical theology I will turn to in the exploration of new quests for God; new quests demand new language, new images, new concepts that open up spaces for the return of the divine.

I described the case of The Passion in detail in Chapter 1 but will, in this chapter, further elaborate on the three processional forms which The Passion adopts and the Dutch context in which this procession practice takes place. After this, I shall explain the concept of 'anatheism' as developed by Richard Kearney and elaborate why his theory seems promising for an exploration of new quests of God in late modern society. Leaning on Kearney and the possibility of a sacramental encounter with God in this contemporary procession, I will offer a theological interpretation of the ritual.

\section{The Procession}

\section{The Procession in The Passion}

The word 'procession' (from the Latin procedere: to move, to proceed) as I use it here refers to "a communal ritualised act, a social action that can - mainly but not exclusively - be identified as religious".1 This ritualised act in The Passion takes on three distinct but related forms: a physical procession with a cross

$9 \quad$ Kaufland, "From the outside", 143.

10 E.g. Motivations from online processions 2014 and 2015.

11 Albert Gerhards, "Prozession II" in Theologische Realenzyklopädie, 27, ed. Horst Balz et al. (Berlin: De Gruyter, 1997), 593-597, 593 [hereafter cited as TRE]. The translation from the German is mine. 
through the city, a virtual procession behind the cross enabled by a secondscreen application, and a virtual Twitter-procession.

Since the first edition of The Passion in 2011, every year some 1,00o people have physically followed a large neon-lit white cross that is carried through the streets by sixteen so-called "cross bearers". ${ }^{12}$ Each year, the procession heads to the square in order to arrive at the main stage at the point in the narrative where Jesus, after his condemnation, is taken away by soldiers. During the live performance of the show in the city square, where a narrator on stage hosts the performance, cameras switches over occasionally to the procession. At these moments, a TV personality in the role of a journalist interviews several participants in the procession (from various religious and non-religious backgrounds) who openly share with millions of viewers their personal motives for following the cross.

By 2014, this physical procession had become so popular that online registration for participation, which opened six months before the event, was fully booked in just a couple of hours. The organizers, therefore, initiated an additional virtual procession by launching a 'second-screen application', which enabled people to follow the procession online and to share their personal motivation for doing so. ${ }^{13}$ This virtual procession drew so many followers that subsequent iterations of The Passion all had this second-screen application (2015 showed a five-fold increase in participants, see the figures below). During the broadcast of The Passion, people were encouraged to join the virtual procession as the text live.thepassion.nl appeared on screen. Upon visiting the website, they would see a pop-up screen with an "I walk along" button, along with an optional textbox in which people could write their motivation for doing so. ${ }^{14}$ Once enrolled in this virtual procession, participants could see the cross and cross-bearers in front of them, and could follow the procession through the streets of the city by scrolling with their mouse or swiping the

12 The organisation set the limit to 1,0oo participants in order to be able to ensure their safety. Fieldnotes 23 March 2014.

13 Definition of 'second screen': "a mobile device used while watching television, especially to access supplementary content or applications". It is used to enhance the TV viewing experience and often generates online conversations around the content. "Second screen". Oxford Dictionary. http://www.oxforddictionaries.com/definition/english/ second-screen. Last accessed May 10, 2020.

14 Many of these were a 'confessional' type of motivation, shared by Christians bearing witness of their faith. Other types of motivation, however, (e.g. humorous ones, cf. Chapter 5 , or motivations that expressed appreciation of the online procession or the impressiveness of the show) also occurred. 


\begin{tabular}{lcc}
$\begin{array}{l}\text { Year/No. } \\
\text { of people }\end{array}$ & $\begin{array}{c}\text { Virtual participants } \\
\text { (rounded figure) }\end{array}$ & $\begin{array}{c}\text { Motives shared } \\
\text { (rounded figure) }\end{array}$ \\
\hline 2014 & 25,000 & 10,000 \\
2015 & 135,000 & 19,000 \\
2016 & 145,000 & unknown \\
2017 & 111,000 & 15,000 \\
2018 & 86,000 & 32,500 \\
2019 & 14,500 & 2,500 (in chat messages), \\
& & 322 (uploaded videos) \\
\hline
\end{tabular}

FIGURE 6 Overview of round numbers of participants in the virtual procession on the second screen

Source: two emails from Cornelis Vlot, market and communication advisor at broadcasting company EO, received on July 26, 2018 and September 23, 2019, and one email from Maartje Nitrauw, "project manager digital" at EO, on September 23,2019 . Vlot in his last email added a disclaimer regarding the dropped number of the 2019 edition by pointing out that in that year a new format was used "which was more of a barrier for those walking along”. According to Nitrauw, people could "choose to upload a video, or type along in the chat. The reason why we chose for video-uploads has to do with the theme \#youarenotalone. We tried to unpack that theme by posting stories online, also stories of 'normal people."' (So not only interviews and videos with the performers, but also interviews on this topic with those carrying the cross in the procession or other people with extraordinary stories).

touchscreen of their devices. Each participant could virtually walk the procession at their own pace in the direction of the main square..$^{15}$

In addition to the physical and virtual procession, people could also join the online Twitter-procession by using the hashtag \#ikloopmee (\#iwalkalong), an initiative launched and promoted by the broadcasting companies. This created another form of virtual procession, which the creators intended to relate this to the second-screen application so that people could not only share their motivations for following the cross by using the open textbox, but also by sharing them on Twitter. However, in reality, the hashtag was also used more independently, as a way of interacting with The Passion in general. This created a 'hashtag community' of participants, in which people had an 'ambient' affiliation to the procession around which they interacted and in which they did

15 Participants actually followed the procession-rehearsal that was recorded on the evening before the event, which is why they could reach the main stage before the procession did so in real time. 
not necessarily interact directly in order to align around a common practice or symbol. ${ }^{16}$

\section{Historical Background and Cultural Context}

As previously suggested, Christian repertoire in late-modern culture is influenced by broader developments and trends in that culture. The procession in The Passion offered offline and online levels of engagement, and has taken on features of multimediality, virtuality, interactivity and connectivity (see Chapter 5 ). The form may be rather new, but processions have a long history, with antecedents in the practices of ancient Israel, and throughout the history of Christian worship in the East and West, to this day. ${ }^{17}$ Processional rites occur either indoors as part of the liturgy, e.g. entrance processions, gospel and communion processions, processions with gifts; within elements of worship that often have a particular purpose, or outdoors, in which case the meaning often predominantly lies in the act of 'being on the move' itself, as well as in the act of self-presentation or putting oneself out there. ${ }^{18}$ Movement, spectatorship and play are characteristics of the latter type. ${ }^{19}$ The procession with the cross that is part of The Passion obviously fully belongs to the outdoor category (as the online shapes are also linked to the offline, physical forms in the open air) with its corresponding features. It stands in the tradition of processions linked to a Christian feast, in this case, the paschal triduum. Over the course of history, several processions during Holy Week have developed, both strict liturgical processions and others with strong links to popular culture (the medieval passion play has its origins in the latter).

In the context of Dutch culture, processions were, for a long time, a controversial phenomenon. Ever since the Reformation got a foothold in what is

16 Michele Zappavigna, "CoffeeTweets. Bonding around the bean on Twitter", in The Language of Social Media. Identity and Community on the Internet, eds. Philip Seargeant and Caroline Tagg (Basingstoke/New York: Palgrave Macmillan, 2014), 139-16o, here 141-142.

17 For historical overviews and extensive lists of bibliographic references see Jan Christian Gertz, "Prozession I", in TRE, 27, 591-593, and Gerhards, "Prozession II", 593-597. Regarding the relation between indoor and outdoor liturgy, the following are particularly relevant: Paul Post, "Ritual Landscape. On Outdoor Liturgy. Processional Parks, Papal Visits, and Popular Rites Associated with Sudden Death", in The Modern Pilgrim. Multidisciplinary Explorations of Christian Pilgrimage, Liturgia Condenda 8, eds. Paul Post et al. (Leuven: Peeters Publishers, 1998), 281-320.

18 Processions of the blessed sacraments, as well as the stational liturgy, which grew out of the early Christian practice of visiting the tombs of the martyrs and celebrating the Eucharist at those sites, are examples of this type. See Gerhards, "Prozession II", 595.

19 Gerhards, “Prozession II", 595. 
now called The Netherlands, public expression of Roman-Catholic faith within the Republic of the Seven United Netherlands (1561-1795) was prohibited. ${ }^{20}$ Freedom of religion was legally established in 1795 , however, processions were again officially banned by Dutch law in 1848 because the revival of processions and communal pilgrimages had stirred up too much turmoil in the predominantly Protestant country. This law prohibited processions in those parts of the country where they had not been a common phenomenon prior to 1848 . This effectively meant that, north of the rivers Rhine, Meuse and Walloon, processions were disallowed, unless they had always been practiced. The river area served as a natural border between the predominantly-protestant northern part and roman-catholic southern part of the country, occupying $2 / 3$ and $1 / 3$ of the land area respectively. ${ }^{21}$ The ban on processions was eventually dispensed with in 1983, however for a long period, procession in the Netherlands has been a phenomenon that was tolerated but not practiced by the majority of the Dutch inhabitants.

In the 1990s, the abolition of the ban enabled a new procession ritual to arise and develop within Dutch culture: the (compassionate or) silent procession can be described as a kind of disaster ritual. ${ }^{22}$ Today, such processions occur after disasters, after fatalities arising from what is termed "senseless violence" (e.g. street violence), after the sudden death of a prominent persons, in the context of national remembrance of the dead of World War II, and within all sorts of memorial and protest rituals. ${ }^{23}$ Whilst liturgical processions today are rather absent, silent processions like these have become a prominent form of public ritual in the Netherlands, although in Dutch the word procession is seldom used for these practices, and they are referred to, instead, as 'silent marches' ('stille tochten').

Paul Post, in his exploration of outdoor ritual, has typified rituals similar to the procession in The Passion as "folklorised liturgy". Acknowledging that

20 A detailed study of Dutch processional culture, on which this paragraph relies, can be found in Peter Jan Margry, Teedere Quaesties: religieuze rituelen in conflict. Confrontaties tussen katholieken en protestanten rond de processiecultuur in 19e-eeuws Nederland (PhD thesis, University of Amsterdam) (Hilversum: Verloren, 2000).

21 The famous Saint John Procession in Laren, that probably dates back to the 15th century and is still held every year, is an example of the latter. See "Laren, H. Jan (Johannes) de Doper", Meertens Instituut, http://www.meertens.knaw.nl/bedevaart/bol/plaats/422. Last accessed May 10, 2020.

22 For an overview of the development of this kind of procession, see Paul Post, "Case studies I: Dutch cases and themes" in Disaster ritual. Explorations of an emerging ritual repertoire, Liturgia Condenda 15, eds. Paul Post et al. (Leuven: Peeters Publishers, 2003), 156186.

23 Post, “Case studies I", 166-172. 
the term is somewhat problematic, Post has rightly pointed to "a fundamental change in the context of ritual and the way it is experienced". ${ }^{24} \mathrm{He}$ has signalled a change in liturgical shape, context, and meaning: ritual moves into the public realm, where it takes the form of a performance for an audience and becomes a spectacle with all the associated rehearsals, scripts, and sponsors. Although Gerhards has described the activity of spectating as part and parcel of a procession, the procession of The Passion affirms that professionalisation and commercialisation are irrefutably part of the tendency that Post describes. The processional practices in The Passion are clear examples of such change, and stand in the broader context of the transfer and transformation of religion as described in Chapter 2. Many people in the Netherlands are relatively unfamiliar with liturgical and/or religious processions; they are likely to be somewhat more familiar with compassionate/silent processions, and these may well form part of their framework when making sense of the procession of The Passion (see Chapter 4). Due to the increase in media attention that The Passion has received over the years, the word "procession" is now used in the public sphere (e.g. in newspapers and TV and radio talk shows) as if it has always been a perfectly normal and customary phenomenon. Yet the historical background of procession rituals and the current religious landscape in the Netherlands make the practice and appropriation of the procession in The Passion a complex and diffuse rather than unequivocal phenomenon.

\section{A Return to God after God: Kearney's 'Anatheism'}

In light of the new quests for God which I read into practices that take place in late-modern network societies, I now turn to explore how an encounter between God and participants may be able to take place in the complexity of this multi-layered procession practice. This exploration may create a susceptibility to the possibility of encounters with God in times when Christian belief is experienced as unbelievable. The philosophical-theological reflection of Richard Kearney on the return to God after the loss of God leads us to a creative hermeneutic through his proposal of a sacramental imagination that entails the sacramental return to the holiness of the everyday. ${ }^{25}$

\footnotetext{
24 Post, "Ritual Landscape", 294-295.

25 The procession with the cross is not simply 'the everyday' though: it is actually a combination of a set-apart object (i.e. the cross) and the everyday of work, watching tv and posting Twitter-messages, as the elaboration of empirical examples below will show. This combination enables the sacred/divine to enter practices of everyday life.
} 
In a late modern Western context, Kearney claims that the question of God is returning with a new sense of urgency. He believes the question to be "an increasingly pressing inquiry for our 'postmodern' age where the adversarial dogmas of secularism and absolutism threaten the option of considered dialogue". ${ }^{26}$ In his book Anatheism, he poses the deeply penetrating question of how we can speak of God after having left God behind: "What comes after God? What follows in the wake of our letting go of God? What emerges out of the night of not-knowing, that moment of abandoning and abandonment? Especially for those who - after ridding themselves of 'God' - still seek God?"27 Kearney's answer to the question 'what comes after God' finds expression in his formulation of a pathway between contemporary dogmatic theism and militant atheism (and, I would argue, agnosticism) - a way that offers a hermeneutical narrative approach with its interpretative focus on 'otherness' and the welcoming of the S/stranger. Anatheism is "an invitation to revisit what might be termed a primary scene of religion: the encounter with a radical Stranger who we choose, or don't choose, to call God". ${ }^{28}$ It is a third way between the polar opposites of certainty "that have maimed so many minds and souls in our history" through which Kearney explores the exciting interpretative possibilities of a "return" to God and a re-imagining of God after the death of God. ${ }^{29}$ Crucial to this third way is the existence within it of moments both of atheism and of theism: it is a return to God after the disappearance of God (ana-theos), a way between naïve faith and the hermeneutic of suspicion. Ana-theism is "another word for another way of seeking and sounding the things we consider sacred but can never fully fathom or prove". ${ }^{30}$ For Kearney, anatheism is not a state, but rather a wager of faith beyond faith that occurs again and again; a wager that "marks a reopening of that space where we are free to choose between faith or nonfaith"; ${ }^{31}$ a moment of creative "not-knowing" that signifies a break with former sureties and invites people to forge new meanings; a movement that refuses all absolute talk about the absolute. Such moments by no means occur only to intellectuals: the anatheist moment can come upon anyone who experiences anxiety, doubt, or disorientation in life. These instants are "experienced

\footnotetext{
26 Kearney, Anatheism, xiii.

27 Kearney, Anatheism, 3.

28 Kearney, Anatheism, 7.

29 Kearney, Anatheism, 2.

3o Kearney, Anatheism, 3.

31 Kearney, Anatheism, 7.
} 
in our bones - moods, affects, senses, emotions - before they are theoretically interrogated by our minds. And they are (...) as familiar to believers as to non-believers". 32

An important element of Kearney's theory is the sacramental imagination. For him, this entails what he terms a sacramental return, a retrieval of the extraordinary in the ordinary: "It marks an opening toward a God whose descent into flesh depends on our response to the sacred summons of the moment". ${ }^{33}$ In this sense, anatheism is a form of post-theism that allows us to revisit the sacred in the midst of the secular. A revisitation that confirms specific rejections: a rejection of the Omni-God of celestial might; a rejection of the idea that God orchestrates good and evil alike. If anything is dead, it is the traditional idea of God, that is, a God as Deus ex machina in times of neediness. Also, if anything is dead, it is the modern individualist conception of private salvation. The sacramental return "is the possibility of a God after God (ana-theos) that signals the return of the sacred after its setting aside (ana-thema)". ${ }^{34}$

Kearney's theory is fruitful for both the interpretation of the procession ritual in The Passion and wider interpretation of contemporary (Christian-rooted) ritual repertoire. By analogy with his 'return to God after God', the procession in The Passion may be described as 'a return to liturgy after the liturgy'. In any one of the three shapes, the procession in The Passion can be understood as ana-liturgy. To many inhabitants of the Netherlands, a procession with a cross is, in many ways, like a complete stranger. In a society where, in the 2oth century, Christianity was increasingly met with hostility and where it has now become mostly irrelevant to many people, this procession - still unequivocally related to the cross of Jesus Christ - is somehow being embraced (I will elaborate how in three sub-cases below). Wherever the procession goes, people participate in the wager. The result of this anatheistic wager is by no means fixed or final: people either choose to follow the cross or they do not. If and when they actually follow the cross, they receive the stranger as a guest. It is their response to the sacred summons of the moment. They allow the stranger to come closer. It may bring them something new. This does not, of course, mean that all those engaging in the offline and online procession consciously experience anatheistic moments, or that they are aware of being in 'a middle section' where they can either choose belief or disbelief. In Anatheism, Kearney approaches the anatheistic wager as a rather individual and rational affair, yet I

32 Kearney, Anatheism, 5.

33 Kearney, Anatheism, 86-87.

34 Kearney, Anatheism, 86. 
propose that there is more space for communality and unintentionality than Kearney admits. ${ }^{35}$

The communality of the anatheistic wager returns in the fact that the mass event is a collective practice, but also in the interpretation of the practice, which is an act performed by participants and scholars alike. Kearney's anatheistic proposal is fundamentally a project of theo-poiesis (Greek, in Latin: theo-poetics): of "God made present in and through making". ${ }^{36}$ It clears spaces for the return of the divine, and this requires humans to become co-creators in the process. "We must return to a God who returns to us. We must aid and even provoke the reappearance of the sacred by rejoining the endless art of creation. Indeed, by opening ourselves to the possibility that we can make with, in, and through God, we may find that the impossible has been made possible - that God makes with, in, and through us". ${ }^{37}$ Practical theology demands that the 'we' in this quotation is taken to refer to participants in the ritual and practical theologians together. On the basis of the research report GIN, I have concluded that many people in the Netherlands no longer actively seek God, and that The Passion does not really arouse curiosity about Christian faith. Yet, the popularity of the procession (measured by the number of participants) demonstrates a certain openness towards the cross. There is a normative dimension to this openness - the normativity of participants who participate in the ritual as the result of an evaluative decision ('in the wager', this is elaborated in more detail below). This allows for theologians to take this one step further and explore the openness as a space where the divine may return (the sacramental encounter being a normative perspective too) an exploration that takes the form of words, of theory, but is performed in line with the openness of participants. Participants in the ritual, together with practical theologians, thus engage in theo-poetics: "a process of creating and recreating the divine in the wake of the death of God".38

Although Kearney writes that the wager of discernment may occur at the most basic affective and pre-conceptual levels, the wager of response is not, in his view, irrational: “... every seeing is a seeing as, a reading of the Stranger as

35 Strikingly, despite many opportunities in his philosophy that allow for an anatheistic interpretation of ritual, Kearney in Anatheism mainly focused on texts, sacred stories/narratives, poetry and art. The volume edited by Kearney and Clemente, The Art of Anatheism, that was published in 2018, has a wider scope as it presents other kinds of art practices as anatheistic projects as well.

$36 \quad$ Kearney and Clemente, The Art of Anatheism, viii.

37 Kearney and Clemente, The Art of Anatheism, viii.

38 Kearney and Clemente, The Art of Anatheism, viii-ix. 
this or that other, as love or hate, life or death". ${ }^{39}$ The difficulty here is that, in the end, what comes out of the wager for Kearney often seems closely bound up with a verbal act (cf. "the radical Stranger who we choose, or don't choose, to call God"40). His theory therefore runs the risk of becoming limited to the mind, to convictions, thoughts and ideas. I want to emphasize, instead, that a return to God, particularly within a 21st century culture of emotion and experience, may also occur in the acting itself. Even without words, it is possible to welcome the stranger in the ritual - a ritual that is often performed together with other people. No matter how small the act of clicking a virtual button, irrespective of the ambivalence that some participants, who physically follow the cross through the streets of the city feel, regardless of the impermanence of their engagement, they act and, by acting, welcome the stranger at their gates. Experiencing rituals as unfolders of meaning within the inviting realms of open spaces does not necessarily entail intellectual consent or theoretical interrogation as a prerequisite. The procession of The Passion is like a stranger walking up to people in Dutch society today. They turn on the television and the web link to the virtual procession pops up - the stranger is knocking on their doors, and they simply engage or refrain from engaging in this collective ritual procession.

\section{Encountering God in Ana-Liturgy}

If, in the ana-liturgical ritual, people indeed encounter the radical stranger whom they may or may not call God - then how might this work? I will discuss this question through three examples from participants in the procession in 2014 and 2015. From a large set of empirical data collected between 2011 and 2016, I chose these examples because they show the diverse ways in which the procession can be seen as ana-liturgy in which God may be found afresh.

\section{Empowering Powerlessness: Firemen in the Physical Procession}

In 2015, The Passion in Enschede took place shortly before the fifteenth anniversary of a catastrophic fireworks explosion that had destroyed the residential area Roombeek. In 2000, the storehouse of a fireworks trader went up in flames, twenty-three people (four of whom were firemen) died, around

39 Kearney, Anatheism, 44-45, italics his.

40 Kearney, Anatheism, 7. Kearney here seems to be "in the word" rather than "in the flesh" (to refer to the title of his chapter on sacramentality and the body), which seems to emphasise his initial verbal focus. 
$95^{\circ}$ persons were injured and 200 houses were destroyed. The calamity had a great impact on the community. Six days after the accident, a silent procession was organised, in which over 100,000 people participated. ${ }^{41}$ In The Passion in 2015 , the physical procession with the cross started in the heart of the (rebuilt) residential area of Roombeek and from there headed to the city centre. Upon the request of the local fire-brigade, several firemen were cross-bearers in this procession. In a preparatory interview between the organising team and the firemen, they appeared to have concrete motivations for joining the procession. One man made clear that by walking in the procession he meant to honour his colleagues who had died in the accident.

At that time, I had only just begun to work at the fire brigade and was only on the side-lines (...), but after fifteen years I notice that the accident still greatly influences the work of the fire department. ${ }^{42}$

Another fireman in that pre-interview had been involved more directly:

I was on one of the first five fire trucks that rode out and ended up in the middle of the explosions. I lost consciousness on site, but I continued working in the days after the fire. It was much later that I got health problems. I had serious whiplash and was medically disqualified from working for $6 \circ \%$ of my regular working hours. The catastrophe literally and figuratively left its scars. ${ }^{43}$

These men do not speak about God, they are living their lives in their regular social circles, and from out of that context, on a particular evening, they join in with a ritual with a cross: they act. Their situation does not necessarily change their acting or the meaning they ascribe to the procession or the cross, but it certainly changes $m y$ view of God. They poignantly take an obviously religious narrative (the passion) and symbol (the cross) in order to readdress their suffering to those present both on the communal level of the fire department, and on their own individual scale, both for others in the Roombeek area and for the broader community of Enschede's inhabitants. In so doing, these firemen unintentionally make visible the way in which the image of God was changed by the suffering of Christ when he carried the cross to which he

41 Source: EnToen.Nu. Canon van Nederland. "Canon van Enschede". https://www.entoen .nu/nl/overijssel/twente/enschede/vuurwerkramp-. Last accessed May 10, 2020.

42 Source: Line-up of The Passion 2015.

43 Source: Line-up of The Passion 2015. 


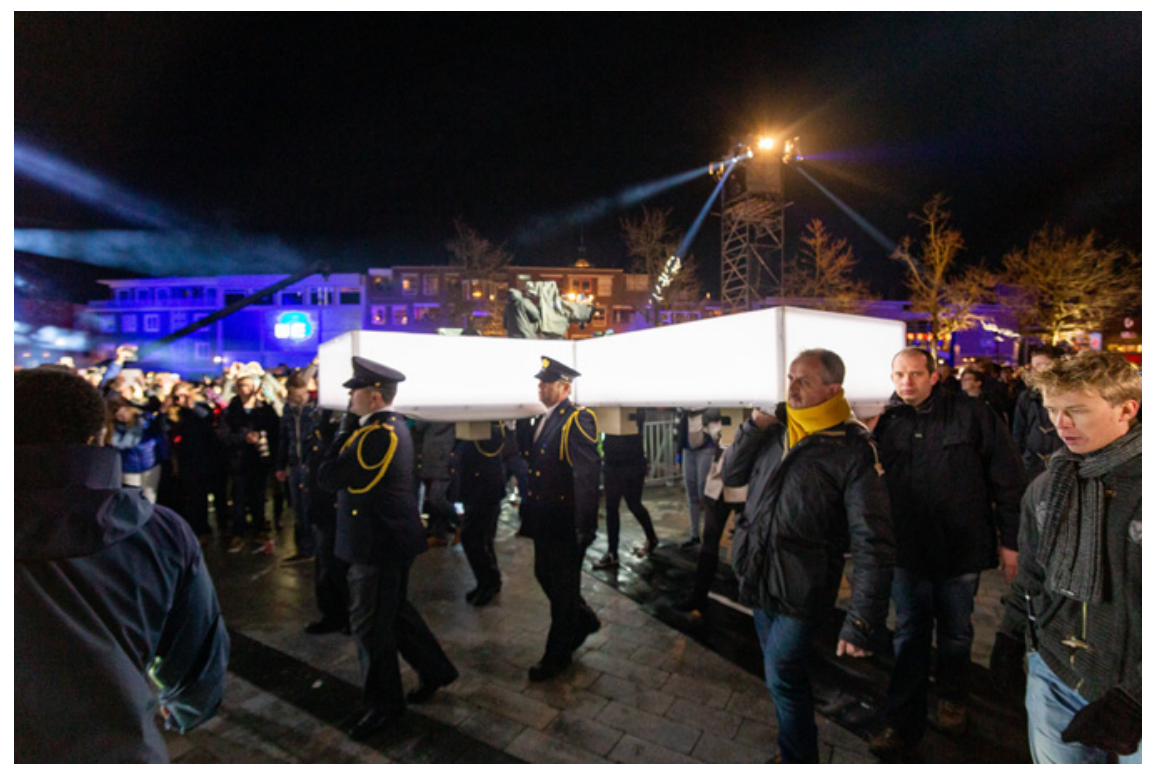

FIGURE 7 Firemen carrying the neon-lit cross

PHOTO: ROGIER VAN DEN BERG. (C) RTV OOST

would later be nailed and on which he would die. We can interpret their ritual acting as an encounter with the divine. Their acting raises the idea that, in the passion, God may have changed more radically than theologians have long thought: in the extraordinary moment and place and setting where they pick up the cross, I want to say that God can become present. The firemen may have participated in the silent march in 200o, but this time, during the procession, they are carrying a cross, which has very explicit theological connotations. As they walk with the cross, it becomes clear to us how the suffering Christ may walk with them.

Participation in the ritual creates a space where an encounter between the firemen, the commemorating community, and the weak God can happen. The anatheist moment involves, in the words of Kearney, "a hope in spite of hopelessness that the estranged God may return in its empowering powerlessness", a sentiment echoing Bonhoeffer's earlier formulations. ${ }^{44}$ When commemorating in situ, the hope that comes with rebuilt houses, streets, parks, and playgrounds stands next to the hopeless, utter darkness of the catastrophe and its still-visible scars. In this ritual, the God of the past, who is the God still to come,

44 Kearney, Anatheism, 68. 
may descend. In an ordinary residential area, in a procession with a Plexiglas cross, the divine may enter with weakness and vulnerability to meet his suffering people. In this perspective, the procession in the Roombeek area is a sacramental return of the holiness of the everyday: a space where the extraordinary may be retrieved in the ordinary. In this procession, the cross-bearers return to "a liturgy after the liturgy", in which the possibility is opened up that they meet a Stranger who suffers and dies, who empowers with powerlessness, who is weak and vulnerable. One whom they may or may not call God.

\section{Letting Go of God:A Lamenting Mother on the Second Screen}

I want to learn to understand why my son was taken away this early, in the prime of his life. I think we need him more than god or Jesus [does], if they do at all exist. My faith had not been very strong, but it was completely taken away from me after the death of my 19-year-old son. How to explain this 'in the love of Jesus'? To my mind that is not possible. Still, I walk along, virtually, maybe I will get an answer some time. But frankly I expect nothing. ${ }^{45}$

On 17 April 2014, a mother entered this text in the text box on the secondscreen application, in order to explain her motivation for joining the virtual procession in Groningen. The text strongly reflects an anatheistic wager: is it not cruel that my son died, and should I not let go of an omnipotent God that takes people like this? It is the existential question of a mother, disoriented in life, not-knowing where to go or how to believe. She leaps upon the anatheistic wager, knowing of death and suffering, bewildered by the meaning of existence, departing from the image of an omnipotent God, struggling with a God of love, because the death of her son was so unjust. Her writing exudes the atheistic "no" that may initiate the anatheist turn. And by clinging to the virtual procession, following the cross through the streets of Groningen city, she makes this turn: "Still, I walk along, virtually". Clearly not expecting to get one, she is hoping for an answer, for the return of God after his disappearance. In the existential darkness of her being, as the mother of a deceased child, the cross comes to her in a virtual but no less real way, and she throws herself in the arms of this radical strange cross. In her "holy insecurity", she keeps the possibility open for the divinity to return back to her in this moment. Her narrative is one big "no", her walking along in the procession is a

45 Source: Excel-file with motivations, acquired via Eo. Translation from Dutch to English language: $\mathrm{MK}$. 
"yes". Kearney writes that our response to the stranger is already a decision: a choice to commit. That is what this mother does, in a moment of truth, where she may not know the truth, but does the truth. Indeed, "Orthopraxis precedes orthodoxy. Trust precedes theory. Action precedes abstraction". ${ }^{46}$ In the moment of her surrender to this virtual procession, in the simple clicking of the button "I walk along" on the screen, the highest deity may kenotically become "the very least of these". The word that pitched a tent with the people empties itself out from a state of transcendence into the heart of her suffering, again becomes everyday flesh, transubstantiates to join this grieving mother. This example shows that the anatheistic space is about humans who, in dark times, have to let go: both of their children and of their images of God. God may be encountered right there.

\section{An Epiphanic Tweet: A Grandmother Joining the Twitter-Hashtag Procession}

On the same day, a female user on Twitter posted the text:

\#iwalkalong special \#thepassion I walk along for my grandson [name] who fights for his life in the IC of UMCG Groningen ${ }^{47}$

The following tweets, both replies to others and the original woman's response to those replies, disclosed that her grandson was very ill. The boy had been born after 25 weeks of pregnancy and had many health problems. ${ }^{48}$ By using the hashtag, and also by repeating the words, she virtually clasped the procession, joining other people in following the cross that was carried through the city. Although sending such a tweet is more volatile than virtually and physically following a cross through the streets of a city, the anatheistic wager is basically the same: in her experience of anxiety about her hospitalised grandchild fighting for his life, the online procession suddenly appears. In this moment, she clutches to the cross, dedicating her own processional act to her grandson, connecting the cross of the suffering Jesus to her own and her grandchild's suffering. She watches virtually behind the cross with her grandson, unintentionally (?) responding to Jesus' appeal to "watch with me for one hour"

\footnotetext{
$46 \quad$ Kearney, Anatheism 44.

47 Tweet sent on April 17, 2014, 5:17 p.m.. For privacy reasons the name of the Twitteraccount is not mentioned here. For verification of data it is available upon request.

48 The mother of the boy keeps a blog on the internet where she frequently posts medical updates about him. This section partly relies on information from that blog. For privacy reasons the web link is not mentioned here. For verification of data it is available upon request.
} 
(Matt 26:40), and therefore also watching with Christ. This opens the space for a sacramental inversion to take place, an exchange of perspectives: by welcoming the cross, the God who is welcomed may welcome the grandmother with her grandchild. ${ }^{49}$ In the past, the woman had posted several tweets about her grandson, as he had been hospitalised a number of times. This time, the processional tweet through, in and by which she links her grandson to the cross "somehow transubstantiates the empirical thisness [of her tweets, $\mathrm{MK}$ ] (...) into something sacred and eschatological", to use Kearney's words. ${ }^{50}$ An ordinary practice becomes a processional ritual that converts the ordinary into a sacred practice. It thus may become a sacramental vehicle that enables an encounter with the divine: the procession-tweet acquires an epiphanic character (i.e. it becomes an embodiment of the sacred), giving a future to past tweets.

\section{Conclusion}

In their reflections on the sacramentality of worship, the Dutch and South African theologians Barnard, Cilliers and Wepener rightly claim that God's presence cannot be manipulated. "God cannot be captured with or within our liturgical ritual acting. His 'real' presence - presentia realis - is an answer to human faith, but never in a causal sense". ${ }^{51}$ I by no means intend to claim that the ana-liturgical ritual causes God's presence. It is rather a matter of fides quaerens figuras: faith (and non-faith) searches for open spaces and forms in which to encounter the divine. I identify this as a theopoetic act: it makes clear "how the divine (theos) manifests itself as making (poiesis)".52 It is a second creation, called for(th) by the first creation: "creation again (ana): a double act where humanity and divinity collaborate in the coming of the Kingdom". ${ }^{33}$

In Dutch late-modern society, where classical liturgy and 'traditional' Christian beliefs are irrelevant in the eyes of an increasing amount of people, the media have re-invented the procession ritual. They have managed to turn a large amount of people with very diverse backgrounds into participants in the procession. Apparently, the conviction that Christian tradition (and, in its

\footnotetext{
49 An adequate elaboration of this sacramental inversion is found in Barnard, Cilliers and Wepener, Worship in the Network Culture, 323-354.

50 Kearney, Anatheism, 105.

$5^{1}$ Barnard, Cilliers and Wepener, Worship in the Network Culture, 330.

52 Kearney, "God Making. Theopoetics and Anatheism", in The Art of Anatheism, eds. Kearney and Clemente, $3-28$, here 3 .

53 Kearney, “God Making”, 3.
} 
slipstream, God) is irrelevant, makes 'religious' practices no longer simply 'not done'. In a post-secular context, religious practices are no longer apologetic, but have transformed into interpretative and contributory practices: the resources of traditions are made available to meaning-making and to the quest for the good life and for the sake of human flourishing. ${ }^{54}$ The opposition between the religious and the secular has been weakened, maybe even surpassed, and there I find a breeding ground for what Kearney calls anatheism. The Passion is announced and organised, people see a strange cross approaching and the procession obtains new, diverse and layered meanings. Part of this society welcomes the cross, either in the physical procession or in virtual form on the second screen or on Twitter. By engaging in this procession ritual, participants very often turn out to actively connect themes related to the procession (e.g. suffering, pain, cross, sacrifice, death) to events they (have) experience(d) in their personal lives, as in the examples that I discussed. ${ }^{55}$ In doing so, they may have encountered the divine in a new way.

The three examples of openness towards the cross that I discussed above have showed how - in the moment and action of connecting their ordinary life, sorrow, grief, pain, health, loved ones, and all darkness to the cross - a space is created in which God, who has never really completely disappeared, can return to people and meet them. A space in which they are (again) presented with the freedom to choose, to imagine different possibilities, and encounter anew. This leads to the conclusion that Dutch society is not simply a society beyond God, and that to (at least part of) its members the re-invention of liturgical ritual is of the utmost importance.

54 See Benjamins, "The Postsecular and Systematic Theology", 116.

55 This claim is, among other things, supported by people's motivations for joining the virtual procession, as derived from the motivations virtual procession-excel sheet (2014 and 2015). Documents obtained via broadcasting company EO. 


\section{PART 2 \\ Cross-Fading Perspectives on the Play}

The broad discussion of the changing character of (Christian) religion through the case of The Passion in Part 1 set the stage for the middle part of this book. Part 2 offers a number of cross-disciplinary perspectives that have resulted from empirical research on The Passion between 2011 and 2018. The results of my ethno-case study on The Passion led me to adopt a number of different viewpoints that are offered as "cross-fading perspectives". In stage lighting, a cross-fade is when lighting levels are gradually altered from one setting to the next. Each lighting-setting in Part 2 gives its own outlook on the play, and unveils particular qualities of Christian ritual practices in our times. The subsequent chapters present a number of crucial elements and aspects of the way in which religious repertoire moves around in contemporary culture. I describe The Passion as a spatial practice (Chapter 4), a ludic practice (Chapter 5), a reflexive practice (chapter 6), and a public theological practice (Chapter 7 ).

Part 2 is interspersed with theological reflections loosely relating to what was presented in the preceding chapter. I offer these reflections in order to show how in times 'after the death of God' the God-question might be thought afresh. 
Mirella Klomp - 978-90-04-44294-8 Downloaded from Brill.com04/26/2023 09:16:19AM via free access 


\title{
Claiming Sacred Ground: A Spatial Practice
}

\author{
With Martin Hoondert
}

It is 8:30 PM on Maundy Thursday, three days before Easter. Welcome to Rotterdam! A world-class city where one can find the colourfulness of our country in every street. But also a city that took a major role in a history of suffering, destruction, death and reconstruction [WWII, $\mathrm{MK}$. A city that, like no other, understands and feels the impact of the age-old and world-famous narrative of suffering, death and resurrection. Tonight, Rotterdam forms the stage for The Passion. (...) The streets of this metropolis are our Jerusalem.

NARRATOR PHILIP FRERIKS, 5 April 2012

(Willem Square, Rotterdam)

Over the years, The Passion has travelled from one city to another: this popular retelling of the last hours of the life of Jesus of Nazareth is an event that has moved across time and space. ${ }^{1}$ Using the ideas of Thomas Tweed, we might say that time and again the Passion has found a temporary dwelling in a particular practice performed by particular people in a particular place. Indeed, every year, another large city is for one night transformed into first-century Jerusalem, with significant locations within the city forming the decor for various scenes in the narrative. The sense of anticipation before the performance commences is always palpable in that place, with giant screens set up in the main square counting down the minutes and seconds until it begins. City governments lobby heavily to bring the event to their square and, once the die is

1 This chapter is partly based on an article previously published as Martin Hoondert and Mirella Klomp, "The Streets of Gouda", in Sacred Spaces and Contested Identities. Space and ritual dynamics in Europe and Africa, ed. Paul Post, Philip Nel and Wouter van Beek. (Trenton, NJ: Africa World Press, 2014), 313-33o. Author's contributions in this chapter are as follows: I wrote the text of all sections, with the exception of 'The Passion as spatial practice', which is based on Hoondert's work and was revised by me for the purpose of publication in this book. 
cast, spend months building up to the big moment. In the weeks beforehand, shop owners change their window displays to feature large white cardboard crosses to help promote their merchandise, local bars and cafes offer "Last Supper" special menus that all feature bread and a red drink of some sort. Local churches, city authorities, schools and universities plan and host multiple side events. National television and newspapers are filled with discussion and commentary about the event in the days leading up to it. It seems as though every year the Passion of Jesus truly takes over a city and the entire country.

On the stage, which is often built on city squares normally used for a variety of events (among other things, markets with food or clothes stalls), the narrator uses the opening sentences to connect the ritual-musical performance of this Christian narrative to a particular locality. The repetition of this explicit connection by the subsequent narrators of The Passion draws the attention to The Passion as a localised and spatial practice. The structuring elements of the network society - mobility, communication technology, globalisation and relocation (see the discussion of Appadurai's -scapes in Chapter 2) might lead us to think that space and place have become irrelevant. However, late-modernity, with its flux and flow, its dynamics and fluidity, transforms our relationship to space and place, and thus requires that these notions are rethought. Academics in various disciplines have risen to the occasion: in both the humanities and the sciences, particularly since the late zoth century, scholars have rediscovered space and place as a research subject, to the extent that this trend has been defined as a 'spatial turn'.2 At the intersections of space and/or meaning, sacrality, religiosity and ritual, important research has been done by historian Mircea Eliade (1907-1986), philosophers Michel Foucault (1926-1984) and Henri Lefebvre (1901-1991), political geographer Edward Soja (1940-2015), Jonathan Z. Smith (1938-2017), and ritual studies scholars Ronald L. Grimes ( $\left.{ }^{*} 1943\right)$ and Paul Post $\left({ }^{*} 1953\right) .{ }^{3}$ Post, in particular, has argued that a

2 See Sigurd Bergmann, "Theology in its Spatial Turn: Space, Place and Built Environments Challenging and Changing the Images of God", Religion Compass 1, no. 3 (2007), 353-379.

3 A useful overview can be found in Kim Knott, The Location of Religion. A Spatial Analysis (London: Routledge, 2005), in which the author locates religion within the social, cultural and physical spaces of the present, using a method informed by the spatial theory of Lefebvre in particular. It is worth mentioning just a few other publications here: Mircea Eliade, The Sacred and The Profane. The Nature of Religion (London: Harcourt Brace Jovanovich, 1987); Michel Foucault, "Of Other Spaces, Heterotopias", Translated from Architecture, Mouvement, Continuité 5 (1984), 46-49; Henri Lefebvre, The Production of Space (Oxford/Cambridge: Wiley-Blackwell, 1991) (original edition published in French in 1974); Edward W. Soja, Thirdspace. Journeys to Los Angeles and Other Real-and-imagined Places (Malden (Mass.): Wiley-Blackwell, 1996). Jonathan Z. Smith, To Take Place. Toward Theory in 
changing post-Christian world requires a new perspective on religion, rituality and sacredness. In his own research, he is particularly alive to the repertoire of actions that occur in new places, as well as the role of spatial context as a factor in people's processes of meaning-making. ${ }^{4}$ He has also supervised a number of $\mathrm{PhD}$ projects that empirically investigate the sacred in ritual repertoires in new places. ${ }^{5}$ However valuable and insightful, these studies do not discuss the respective rituals from a theological perspective. In this chapter, we will focus on The Passion as a ritual-musical passion performance that has moved into and occurs within the (secular) public sphere, investigating it as a spatial practice.

The localised practice of The Passion, as emphasised by the narrators, understood against the background of the spatial turn, leads us to formulate the following question: how does the spatial practice of a Christian ritual form in a city square turn this square into a sacred place? The Gouda edition of The Passion in 2011 will serve as a specific case in this chapter. We will first discuss some core concepts, and then interpret The Passion as a spatial practice in which physical, ritual, and musical spaces come together. As the stage for this Christian-rooted multimedia event was erected in the public space, it obviously takes place, in some sense, on contested ground, and our attention in fieldwork was drawn to diverging appropriation of this practice. In conclusion, we will, therefore, expand on the complexity and ambiguity of the sacralising of public space in a secularised context.

Ritual (Chicago: University of Chicago Press, 1992). Ronald L. Grimes, Rite out of Place: Ritual, Media and the Arts (Oxford: Oxford University Press, 2006), esp. 101-116; Paul Post and Arie Molendijk, eds., Holy Ground. Re-inventing Ritual Space in Modern Western Culture (Leuven: Peeters Publishers, 2010); Paul Post, Philip Nel and Walter van Beek, eds., Sacred Spaces and Contested Identities. Space and ritual dynamics in Europe and Africa (Trenton: Africa World Press, 2014).

4 Cf. his fields of the sacred as discussed in the prologue and the transfer of a 'basic sacral' attitude and behaviour to various domains in chapter 2 .

5 Juchtmans, Rituelen thuis; Judith Tonnaer, Bomen voor het leven: Een studie naar een hedendaags collectief herdenkingsritueel voor overleden kankerpatiënten, Netherlands Studies in Ritual and Liturgy 11 (Groningen/Tilburg: Instituut voor Liturgiewetenschap/Instituut voor Rituele en Liturgische Studies, 2010); Logan Sparks, Ambiguous Spaces. A Contextualisation of Shared Pilgrimage in Ephesus (PhD thesis, Tilburg School of Humanities s.l., 2011); Schippers, Sacred places in the suburbs; Laurie Faro, Postponed monuments in the Netherlands. Manifestation, context, and meaning (PhD thesis, Tilburg School of Humanities s.l., 2015). Martijn de Ruijter, Confining frailty. Making place for ritual in rest and nursing homes, Netherlands Studies in Ritual and Liturgy 18 (Groningen/Amsterdam: Institute for Christian Cultural Heritage/Instituut voor Rituele en Liturgische Studies, 2016). Wijnia, Making Sense; Suzanne van der Beek, New Pilgrim Stories: Narratives, Identities, Authenticity (PhD thesis, Tilburg School of Humanities s.l., 2018). 


\section{Space, Place and the Sacred}

Space and place are often used as interchangeable notions, but can, nevertheless, be distinguished. Generally, theoretical distinctions between space and place boil down to space being considered as more abstract, while place is taken as a specific location created by human experiences. ${ }^{6}$ Space offers a condition for anything that exists, while place exists when space is filled with meanings and objectives by human experiences that are particular to this space. ${ }^{7}$ Space and place are inextricably related, which may be the reason why they are not always distinguished and are often used in the same breath. However, in this case, we clearly recognize that The Passion is performed in the public domain (space) and, more specifically, in the market square in Gouda (place).

The notion of 'the sacred' has been the subject of strong debates in religious studies and theology for over a century. Lieke Wijnia in her PhD thesis on the sacred in music thoroughly discusses a wide range of viewpoints, pointing, among other things, to two fundamentally different approaches, one substantive (referring to the sacred as a powerful manifestation of reality) and one situational (recognising that nothing is inherently sacred). ${ }^{8}$ The latter approach has a long tradition of describing 'the sacred' as 'set apart', thus relating the sacred to the human activity of interpretation. ${ }^{9}$ Sociologist Emile Durkheim, for example, in his definition of religion, singled out the quality of being 'set apart' as a defining feature: "A religion is a unified system of beliefs and practices relative to sacred things, that is to say, things set apart and forbidden.... ${ }^{10} \mathrm{He}$ emphasised the significance of human action, connecting sacrality to consecrating actions. ${ }^{11}$ Almost a century after Durkheim launched his theory, Gordon Lynch proposed a reinterpretation of it, criticising Durkheim's

6 Cf. e.g. philosopher Yi-Fu Tuan, Space and Place: The Perspective of Experience (Minneapolis: University of Minnesota Press, 1977); or geographer Edward Relph, Place and Placelessness, 14th ed. (Los Angeles (CA): Sage, 2016).

7 Tuan, Space and Place, 4.

8 Cf. Wijnia, Making Sense, 31-48. Post has argued that the opposition between substantialists (/essentialists) and situationalists should not be exaggerated. Cf. Paul Post, "Complexity and conflict. The contemporary European church building as ambiguous sacred space", in Post, Nel and Van Beek, Sacred spaces and contested identities. 241-265, here 243. Wijnia, Making Sense, 33 .

10 Durkheim, The Elementary Forms, 47. On the 'set apart', also see Matthew Evans, "The sacred. Differentiating, clarifying, and extending concepts", Review of Religious Research 45, no. 1 (2003), 32-47.

11 See Schippers, Sacred places in the suburbs, 6o, where she writes that the act of sacralising may be extended from the concept of religion to sacred places and objects. 
radical separation of the sacred and the profane, and his tendency to substantialize the sacred by assuming that the power and significance of the sacred derives from the human experience of participating in the self-transcending reality of the social group. ${ }^{12}$ Rejecting this ontological claim, Lynch nevertheless maintains Durkheim's assertion "that the radical otherness of sacred forms is experienced by their adherents as non-contingent - an absolute reality that stands over and above the mundane, contingent nature of everyday life". ${ }^{13}$ Regarding Durkheim's classification of 'sacred things' as things set apart, Wijnia notes that, in ethnography studying the sacred, the researcher should distinguish between 'things that are set apart' and 'the process of setting apart', the latter being not only a physical but a mental process. ${ }^{14}$

When it comes to the triad space/place - ritual - sacrality/religion, both Jonathan Z. Smith and Grimes, similarly depart from the (situational) approach that sacrality is not inherent to a particular place or object. Yet each of them soon goes his own way, to a different end of the spectrum. Smith asserts that "Sacrality is, above all, a category of emplacement", while Grimes maintains that the ritual performance or act is decisive in making a space/place sacred. ${ }^{15}$ Grimes even explicitly states that "Sacrality is not a quality of places, it comes and goes depending on the way people act, what they say, and how they feel about the specific place". ${ }^{16}$ Empirical studies often show that the theoretical distinctions are not as sharp as assumed: what takes precedence in the process of sacralising (place or gesture) probably differs from one case to another. ${ }^{17}$

With these scholars, we take the sacred as a label that people (individually or collectively) can attach to a specific place, either because the place calls forth ritual performances or gestures, or because ritual performance/gesture occurs in a specific place that thereby becomes sacred. The (situational) approach seems to us to be particularly suitable in late-modern societies

\footnotetext{
12 Lynch, The sacred in the modern world, 26.

13 Lynch, The sacred in the modern world, 26.

14 Wijnia, Making Sense, 41.

15 Smith, To Take Place, 104; Ronald L. Grimes, "Jonathan Z. Smith's theory of ritual space", in Religion 29 (1999), 262-273.

16 Schippers, Sacred places in the suburbs, 61. The information on Grimes' view was derived from a personal email he wrote to Schippers on December 12, 2010.

17 Post and Molendijk, "Introduction", in Holy Ground, eds. Post and Molendijk, 1-13, here 8. Eric Venbrux in his contribution to that edited volume convincingly asserted that it works both ways: "the gesture can make the place sacred, and a sacred place provokes the gesture". Eric Venbrux, "Ritual Space and Ritual Gesture. Three types of ritual communication in throwing coins into the water", in Holy Ground, eds. Post and Molendijk, 301-312, here 312 .
} 
where processes of meaning-making and of valuation have changed. As liturgical scholar Marcel Barnard has claimed, in line with the theory of Manual Castells:

late modern society is characterized by a 'plural authority structure'. Power and authority are divided, and to a considerable extent lie with individuals, small groups or interest groups that express themselves through ubiquitous networks. This also holds for the authority by which particular events or texts are being interpreted. (...) People compose their own religious life, if so desired. ${ }^{18}$

Indeed, whether things are sacred or not depends on whether or not these things are subjected to sacralising practices. The sacred is a result of the human activity of interpretation: sacrality is in the eye of the beholder. In the public sphere, this means trouble, as Smith also emphasizes, "sacred places should be seen as arenas in which the balance of power is constantly switching between insiders and outsiders, rulers and followers, old and young people, men and women. Sacred space is contested space." ${ }^{19}$

\section{The Passion as Spatial Practice}

The opening sentences and the performance of The Passion that followed turned Gouda, for a period, into the holy city of Jerusalem, where the final hours of Jesus' life took place. Now that we defined some significant notions and relations, we will turn to address the question of how, in the market square in Gouda, this spatial practice worked - or how, with reference to the title of a book by Henri Lefebvre, space was 'produced' by the performance of The Passion. ${ }^{20}$ This will help us better understand the next section, where we discuss how this sacred space could (or could not) become both sacred, and contested at the same time. In his book, Lefebvre suggests that place never acquires a

18 Marcel Barnard, "Bijbellezen als textiele werkvorm. 'O Meester, Slaaf en Broeder, Geslachte en Verrezen God'”, Schrift. Tijdschrift over de Bijbel 270, 46, no. 1 (2014), 30-34, $3^{1}$ (translation by Klomp). Cf. also Barnard, Cilliers and Wepener, Worship in the network culture, 77. Barnard takes 'plural authority structure' from Manuel Castells, The information Age 2. The Power of Identity (Oxford: Blackwell Publishers Ltd, 1997/2004). Castells quotes David Held, "Democracy, the nation-state and the global system", in Economy and Society 20, no. 2 (1991), 138-172 at 161-167.

19 Schippers, Sacred places in the suburbs, 62.

20 Lefebvre, The production of space. 
definitive shape, but is always on the move: place is actively produced, and is therefore never abstract or passive. The meaning a place has is meaning that comes into being in what he calls 'spatial practice': the ways in which people generate, use, and perceive space. Meaning accordingly develops in doing, on the one hand, and in understanding and experiencing, on the other. Attribution and appropriation are both encompassed in spatial practice. ${ }^{21}$ We identify four (different, though related) aspects: physical, ritual, musical and mental space. Throughout these spaces, the event is also inevitably a social space.

\section{Physical Space}

When reflecting on The Passion as spatial practice, we firstly find that the performance took place in a physical space. The city centre of Gouda is old and has many historical buildings. The market square, where the town hall, which dates back as far as 1459, is located forms the heart of the city centre. Very close to this market square, we find the large gothic Sint Jan church with its famous stained-glass windows. Furthermore, Gouda is a city known for its cheese and its candle makers. This typically Dutch place serves as the stage for an age-old biblical narrative. For the duration of the performance (maybe we should also include installation and dismantling of the stage), the city is taken over by the makers of The Passion. The market square is staked out for the audience, actors and orchestra, and the streets of Gouda are claimed by a procession carrying a big, fluorescent cross. For the duration of the event, a total of go minutes, TV viewers find themselves transported to Gouda and the market square, and participate in the event (either in real time, or afterwards through the internet).

\section{Ritual Space}

The Passion is also a highly ritualised performance that turns the city into a ritual space, in which the story of Jesus is told, sung and portrayed. This ritual action, song and speech are goal-oriented, with the aim of 'claiming' physical space so that the city will become 'saturated' with meaning, and the centre of Gouda does indeed become a sacred space. The ritualised space of the city centre is therefore inherently also a politicised space, as the organisers of The Passion intentionally make the passion narrative part of a public sphere in which religion is often considered to belong 'behind the front door'.22 As much

\footnotetext{
21 Cf. Post and Molendijk, Holy Ground.

22 Cf. Irene Stengs, "Public practices of commemorative mourning" in Holy Ground, eds. Post and Molendijk, 119-143, here 131. Stengs claims that the ritualised space of the roadside memorials (for road traffic victims) is also a politicised space, as relatives place the victim in the political context of protest against ongoing traffic disasters.
} 


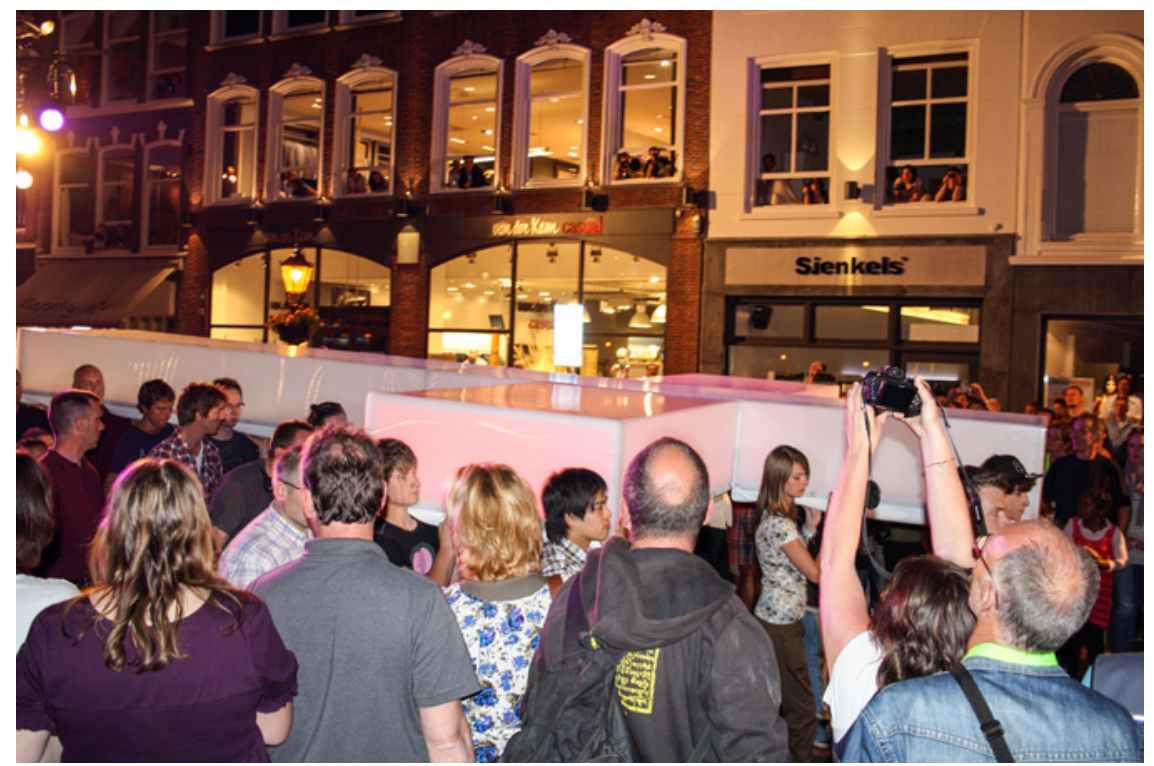

FIGURE 8 The procession with the cross passing the audience in the Market square in Gouda, while making its way to the main stage PHOTO: (C) HIJME STOFFELS

as it is a spatial practice, it is a social practice which, as we will demonstrate below, has formed part of the conflicts that The Passion has generated.

\section{Musical Space}

Thirdly, the performance, besides being a physical and ritual space, through its characteristic use of pop songs, turns Gouda and its market square into a musical space. ${ }^{23}$ By choosing Dutch-language hits, the biblical story of Jesus' last days and hours is integrated into a Dutch context. On the one hand, the songs are part of the story; on the other, they reinforce the Dutch décor by which the performance is surrounded. However, when regarded as spatial practice,

23 Cf. Barry Truax, Acoustic communication (Norwood: Ablex, 1984); Raymond Murray Schafer, The soundscape: our sonic environment and the tuning of the world (Rochester: Destiny Books, 1993); Peter Sloterdijk, In hetzelfde schuitje: proeve van een hyperpolitiek (Amsterdam: Arbeiderspers, 1997); Marcel Cobussen, "Verkenningen van/in een muzikale ruimte. Over Peter Sloterdijk en Edwin van der Heide”, in Interakta \#5. Grootstedelijke reflecties. Over kunst en openbare ruimte, eds. H.A.F. Oosterling and S. Thissen (Rotterdam: Faculty of Philosophy, Erasmus University, 2002), 208-211; Martijn Oosterbaan, "Sonic Supremacy. Sound, Space and Charisma in a Favela in Rio de Janeiro", Critique of Anthropology 29, no. 1 (2009), 81-104. 
the music has a more significant effect: it stakes out the space, not only in a physical, but also in a symbolic sense. While it is true that music has a certain inherent boundlessness, there are nevertheless differences in the impact that music has in relation to the position of the listener. Music tends to have a greater impact on those closer to the source, closer to the performer. This is related in particular to the multi-sensory experience that music provides: those who are close to its source, hear, feel and see the music being performed. To those who are at more of a distance (physically on the square, or as TV viewers) there is less of a sensory appeal: the ability to feel and see the performance is diminished, the volume decreases and, in the case of $\mathrm{TV}$ viewers, becomes dependent on the person with the remote control. The experience of musical space through the body therefore marks out different locations: ranging from zones in which the musical experience is more or less intense, to parts of the city that fall outside of the musical space of the performance. However, the musical space can also be interpreted in a symbolic way: the Dutch-language hits can invite people to engage in The Passion as a performance, but may also 'scare them off' or deter them.

Thus far, we have not elaborated on how the performance of The Passion, as well as receiving approval from many, is also sometimes met with rejection. The physical, ritual, and musical aspects of this spatial practice has sometimes generated conflicts, caused by the fact that The Passion as a performance simultaneously serves quite different interests: evangelisation, promotion of the city of Gouda, and entertainment. The Passion not only tells the story of Jesus' last days and hours, but also tells of a culture that employs and explores a new way of searching for its religious roots, with all the attendant clashes that go with this. Viewed from this perspective, The Passion represents a social space: an area in which 'fans' and 'haters', insiders and outsiders, do battle.

\section{Mental Space: Appropriation}

The spatial practice of The Passion not only comprises the physical, ritual and musical space, but attribution and appropriation are also part of spatial practices. Mindful of the processes of transfer and transformation of ritual repertoire that we described in Chapters 1 and 2, 'secular' pop songs are appropriated in a new context. This context is formed not only by the frame of the biblical narrative, but also by the context of the performance, which is moulded by the singers playing their role, by the musicians, the images, the marketplace of Gouda, and the procession of the cross, etc. For the participants (audience, performers) the performance is a multi-sensory experience. The connotations attached to each person's experience of the performance are an important aspect of the appropriation process, as it is influenced by previous experiences. 
The work of French linguist Gilles Fauconnier can help to gain more insight into how this appropriation works. Fauconnier's theory of how meaning is constructed in language is based on the faculties of the human mind and sheds light on how the structure and use of our language is able to point to so-called 'mental spaces' (separate domains of referential structure) and conceptual projection. ${ }^{24}$ We will, therefore, briefly discuss some of the relevant mental spaces that can be blended into peoples' experience and appropriation of The Passion. First, there is the pop scene and people's personal (positive or negative) experiences with pop music. Appropriation of The Passion depends partly, we presume, on peoples' familiarity with the pop songs that are used in the performance. Second, the biblical narrative not only provides the frame to which the pop songs are transferred, but also a mental space in itself. As with the pop songs, peoples' familiarity with the biblical narrative also influences their appropriation of The Passion. A third point of reference is the genre of the musical and, in particular, the musical Jesus Christ Superstar, composed by Andrew Lloyd Webber and Tim Rice, which was performed for the first time in 1971 on Broadway. A film adaptation of Jesus Christ Superstar was released in 1973 and became very popular among the Dutch, and, in 2005, a Dutchlanguage performance of the musical took place. A fourth mental space is that of the many movies about the passion of Jesus Christ, which have been released over the years, one of the most recent being Mel Gibson's The Passion of Christ (2004). Fifthly, there is a wide tradition of passion plays throughout the world, but also in the Netherlands in the southern village of Tegelen where they have been performed since 1931 and take place quinquennially. Sixthly, there is a strong tradition of musical passion performances in the Netherlands. These are highly popular in Dutch culture, especially Bach's St Matthew Passion, but also his St John Passion, both of which are frequently performed in churches and concert halls during Lent. The Dutch love Bach..$^{25}$ Since the year 2000 , a revival seems to have taken place, as a significant number of new passions have been composed and performed, and, judging by attendance, seem to be highly appreciated. ${ }^{26}$

\footnotetext{
24 Gilles Fauconnier, Mental Spaces. Aspects of Meaning Construction in Natural Language (Cambridge: Cambridge University Press, 2010).

25 Emiel Wennekes, "Wie zingt nu eigenlijk de paashaas? Nederland en de MatthäusPassion", in De geheimen van de Matthäus-passion. Ambacht en mystiek van een meesterwerk, ed. Pieter Dirksen (Amsterdam: Balans, 2010), 105-123.

26 Mirella Klomp, "Joseph \& Jesus”; Mirella Klomp, "Passio - Compassio. J.S. Bach's Passions Transformed into a Passion Transcending Christianity", in Retrieving Compassion: Global Ethics, Human Dignity, and the Compassionate God, eds. Frits de Lange and Julie Claassens
} 


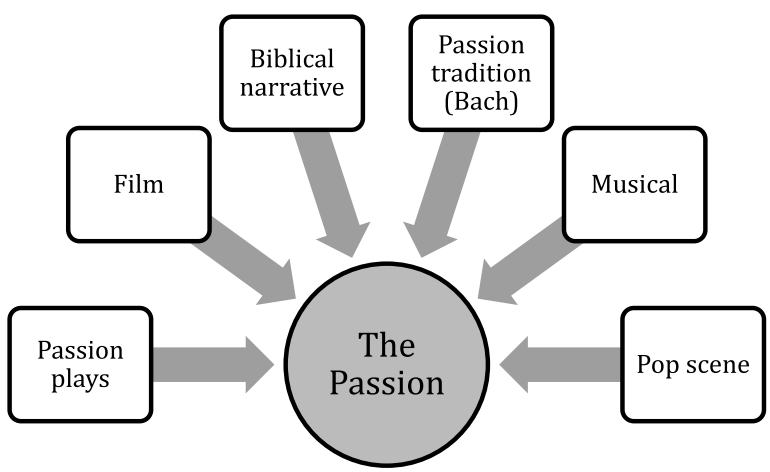

FIGURE 9 Mental spaces that may influence the appropriation of The Passion

The appropriation and appreciation of pop songs as part of the performance of The Passion depends, at least partly, on the successful integration of diverse mental spaces into a single blend. If participants in the audience or on stage, either individually or as a group, cannot or will not accept the popsongs as a way of telling the story of Jesus' last days in a new, contemporary format, a conflict may arise: the use of pop songs in the context of a biblical narrative will make The Passion 'contested ground' in several ways, as we will see.

\section{Contested Ground and Multidimensional Space}

From the very first performance in Gouda in 2011 onwards, The Passion has sparked sharp debate between people who are enthusiastic about the phenomenon and those who disapprove. Local authorities, for example, were happy to be able to put Gouda on the map in 2011 in (what they considered to be) a positive fashion. Prior to the performance, protests began to surface from various different directions. On social media, one person tweeted "Performance of The Passion in Gouda (...) is insulting and contempt of the Gospel", and an inhabitant of the city followed this with a complaint about the noise and the crowds and was worried whether she would be able to even park her car that

(Eugene OR:Wipf and Stock, 2018), 187-202; Mirella Klomp, "Ecclesioscapes: interpreting gatherings around Christian music in and outside the church. The Dutch case of the 'Sing Along Matthäuspassion'", in Studying Congregational Music. Key Issues, Methods, and Theoretical Perspectives, eds. Andrew Mall, Jeffers Engelhardt and Monique Ingalls (Abingdon: Routledge, forthcoming). 
afternoon. ${ }^{27}$ After the performance, the mood on the square (at least among the audience around me) seemed generally appreciative. However, in 2014, a Dutch journalist and TV presenter who had been an atheist since childhood ${ }^{28}$ was unmistakably negative on Twitter, and called the event 'religious kitsch': "The Passion is a violation of, of, of so many things, it makes you awfully sick \#relikitsch". ${ }^{29}$ Indeed, as Schippers has stated, sacred space is contested space. During our research in the field, we encountered several instances where the interpretation and evaluation of The Passion in the market square was not only diverse, but also conflicting and, at least for the duration of this spatial practice, turned the space into contested ground. ${ }^{30}$ Post is another theorist who highlights this potential for conflict, asserting that, in the triad of place, ritual and sacrality, space and place not only interact, but also entail contestations. Exploring the complexity, layered character, ambiguity and ambivalences of spatial practices, he sets out four dimensions, which we will touch upon in the following discussion of three examples.

\section{The Market Square: Object of City Marketing versus Business Interest} The producers of The Passion chose the city of Gouda because it is a mediumsized city, where the performance of a passion like this would have a large impact and get a lot of attention, both on a local and, through live TV coverage, on a national scale. The city council then adopted the project in order to raise the profile of the city. ${ }^{31}$ Some 1.5 years before the event, the city had been in the national news for a few weeks because of riots and misbehaviour by some of its youth. After Gouda was approached, the city council decided to seize upon the chance to market the city and the opportunity to use The Passion in order to show that Gouda is a beautiful historical city where nice events

27 Jan-Willem (@papavanlara), “Uitvoering 'The Passion' in Gouda van EO en RKK is schoffering en minachting van het evangelie. HC zondag 35 v/a 98", Twitter, April 21, 2011.

28 Teun van de Keuken, Puur en eerlijk: de boodschappen van een keurmeester (Amsterdam: Thomas Rap, 2014).

29 Tweet by Teun van de Keuken @teunvandekeuken, "De Passion is een verkrachting van, van, van zoveel dingen, dat je er hartstikke misselijk van wordt. \#relikitsch", April 15, 2014, 4.38 p.m.

30 Martijn Oosterbaan, in an interesting article, demonstrated how the soundscape forms an important element of the public space of the favela and reveals many of its power relations, thus contributing to a multi-sensory conceptualisation of place. Oosterbaan, "Sonic Supremacy". His argument seems less relevant in the case of The Passion, as this performance was not the spatial practice of one clearly defined group, but more an interplay of various parties and individuals.

31 Information on the city (council) in this sub-section is taken from an interview I did with Jacoline Stout and Andrea Olieman, municipality of Gouda, February 2012. 
are able to take place. As it turned out, the event did indeed generate an influx of tourists. It also had an 'empowering' effect on the city's inhabitants, local organisations and entrepreneurs proving that they could bring about something good. It thus had an unexpected positive influence external to the passion performance itself. As philosopher Liliana Gómez has discussed, the performance element of festivities and celebrations can often play a cohesive role in urban societies. ${ }^{32}$

Nonetheless, not all were happy with the performance of this mega-event in the physical space of this particular market square, as can be seen from the legal proceedings that took place only two days before the actual event. On Monday, when the organisation had started building the stage, one of the entrepreneurs of one of the shops in the market square slowly began to realize that this was going to be a huge event and discovered that the stage would physically extend to only a few meters from his shop-window. He sued the municipality for (expected) loss of income. The economic interests of the shop owner conflicted with the city council's interest in promoting the city through the performance of this Passion. The entrepreneur lost the case: consequences such as this, as well as potentially positive impacts on other occasions, were considered to be inherent in having a shop on the market square. As one of the aldermen of Gouda reportedly said: 'this time the disadvantage is yours, next time it is your neighbour's'. All entrepreneurs in the market square collectively share in what happens in 'the living room of the city'.

The spatial practices of The Passion prompted contestations in relation to the physical space of the market square, as it had to be prepared for such a huge musical performance. The contestation thus had to do with the size of the event. In the ambiguity and ambivalences of this spatial practice, we here recognize what Post calls 'sacral zoning'. Sacrality is connected with ritual, and the centre of the ritual here was the stage. "The zoning connected to ritual and liturgy brings all kinds of tensions with it, for it has to do with marking off and setting boundaries that are always under pressure", Post claims. ${ }^{33}$ In this case, the entrepreneur saw the sacred space - physically claimed by the stage - clash with the walking space of his customers. This incident demonstrates that, apart from the event taking up a physical and ritual space, it also constitutes a social space where, in this case, different interests turn out to act in explicit opposition.

\footnotetext{
32 Liliana Gómez, "The Urbanization of Society. Towards a Cultural Analysis of the Sacred in the Modern Metropolis", in The Sacred in the City, eds. Liliana Gómez and Walter van Herck (London/New York: Continuum, 2012), 31-51, here 37. 


\section{A Musical Event: Vehicle for Evangelisation or an Entertainment Show?}

The broadcasting companies EO and RKK, the two churches involved and the Dutch Bible Society intended, through The Passion, to present the gospel in modern 'clothing'. Using pop songs, contemporary language, and modern techniques, and by putting on a large-scale broadcast event live in a primetime slot, their primary aim was to reach young people, 'to give the gospel back to the street'. ${ }^{34}$ The event raised objections and critical comments from believers belonging to various churches. A month before the event was to take place in Gouda, three orthodox reformed churches, supported by the local branch of the Reformed political party SGP (Staatkundig Gereformeerde Partij), asked the city council to withdraw the license that had been granted to the organizers. They submitted a joint letter through which they communicated their objections to the Mayor and Aldermen of the city of Gouda, stating that:

The suffering, death and resurrection of our Lord Jesus Christ lie at the core of our reformed confession of faith. (...) The lived reality of being sinners before God, our personal faith that embraces the redemption through the sacrifice of Jesus Christ, and the victory over death (...) we experience these things with silent astonishment; they lead to worship and humble confession. (...) We find it repulsive that the suffering of Jesus is made the subject of an event through noisy (pop) music and filmed play-acting. The essence of the passion narrative is thus degraded to entertainment. (...) $[\mathrm{H}]$ owever beautiful our city - we consider it profoundly inappropriate to comply with this event in order to promote the city and to cooperate in its production as a partner. The suffering and death of the Lord Jesus Christ is too sacred and devote to us to serve as the basis for city promotion. ${ }^{35}$

The objections obviously concentrate both on the musical and the ritual space that The Passion creates, and, at the same time, relate to the physical space of Gouda with its situation at the tail end of the orthodox Bible belt. "These pop songs have nothing to do with the passion narrative", the chairman of SG P

34 According to Leo Fijen, then director of RKK broadcasting company (that later merged into KRO), in an interview by $\mathrm{MK}$, December 2011.

35 "Aan het College van Burgemeester en Wethouders van de gemeente Gouda", (letter of objection against The Passion), Gereformeerde Gemeente Gouda et al., obtained via http://www.nd.nl/images/library/PDF/gouda.pdf on March 22, 2012. Quotation translated by MK. 
Gouda explained in an interview, and in his opinion the event was surrounded by a lot of noise. In response to the question of why he called the music "noise", he declared that this was a matter of musical taste, but also that these songs were not pious: "The passion narrative should not be told through cheap music". ${ }^{36}$ The SGP took offence particularly at the fact that the municipal council had not bothered to inform them and the reformed churches in Gouda at an earlier stage; the council could have known that this was going to cause trouble. At the time that the aggrieved parties submitted their objections, they had not yet been informed about the procession with the cross through the city streets. Afterwards, their spokesman declared that they had considered this ritual practice objectionable as well, for similar reasons: "The suffering and death of our Lord Jesus Christ is so sacred and intense... that it must be treated with veneration, and is not something to be played with". ${ }^{37}$ The aggrieved parties clearly were not open to blending the mental space of passion plays and that of the pop scene within their appropriation and appreciation of The Passion. The mental space of the Biblical narrative to them was so exclusive and sacred that it should not be linked to other mental spaces. The council responded to these objections, saying that an event like The Passion is in keeping with a pluralist society as well as with Gouda's tolerant image. ${ }^{38}$

Precisely the same complaints were put forward by a Roman Catholic blogger, who despite coming from quite a different spiritual and ecclesial tradition, and despite an openness towards contemporary culture, reacted against several ads for The Passion, writing that:

It will be nice, I am sure. We cannot let any opportunity pass by to contextualize and present Christianity, and the church should not position itself outside of our media culture. But I have mixed feelings about this. I will not be attending. What's this, 'shops are open'? What's this, 'a nice evening in Gouda'? What this 'sparkling show'? Something wrenches my heart. The way of the cross is one of modesty. It is delicate. These are stations of the cross. Statio. Standing still, (frozen in time). No spectacle, no 'shopping with Peter' and 'Doner Kebab Judas'. It is about falling three times, a distressed mother with tears in her eyes, a desolate Jesus, 30

36 Arjan Versteeg, member of the City Council of Gouda on behalf of the SGP, interview by MK, February 23, 2012.

37 Rien Hoek, spokesman on behalf of the three reformed churches, interview by мк, March 8 , 2012. Translation by M K.

$38 \quad$ Newspaper article in Nederlands Dagblad, 18 March 2011. 
pieces of silver, and gambling over his robe. It is a crucifixion. (...) Jesus dies without cocktail nuts. ${ }^{39}$

His objections do not so much relate to the musical space created by the performance of modern pop songs within the frame of a biblical narrative, neither do they relate to the ritual space created through the performance in the square and the procession with the cross, or to the physical space of Gouda's market square. His objections appear to relate to the scale of this mega-event, the media campaign behind it and the promotion surrounding it. In his view, these are at odds with what he sees as the core characteristics of the crucifixion.

Whilst some of the organisations putting on the event saw The Passion as a vehicle for evangelisation, the objections voiced by individuals such as this blogger arise because of the entertainment character of the show. This ambiguity relates to what Post describes as a trend towards the relativisation of sacrality, in the sense that it becomes bound up with changing societal and cultural circumstances. In the case of the churches and the political party discussed above, that entails a connection to changing media culture; in the case of the blogger, to consumerism and informalisation. "Sacrality itself represents a program", according to Post. ${ }^{40}$ This holds both for the actualisation of Christian ritual repertoire in late-modern culture (or, what some would call, a relativisation of the sacred), and to the insistent demands of solemn rituals, which are here associated with opposition to banality of modernity, and influence of secularisation (what Post would call a 'countermovement', and Barnard 'resistance identity'41).

\section{The Separation of Church and State at Stake}

The broadcasting companies involved in The Passion have a missionary goal that they "have never been secretive" about. ${ }^{42}$ Gouda, as we have already emphasised, adopted the Passion project for reasons of city marketing. In the opinion of city officials, Eye2Eye Media has proved to be a "secular, professional production company", easy to approach in an atmosphere of open exchange;

39 Blog by Eric van den Berg, "The Passion Gouda: Jezus sterft zonder borrelnootjes". April 21, 2011. https://www.mediakathedraal.nl/the-passion-gouda-jezus-sterft-zonder -borrelnootjes/. Last accessed May 10, 2020. Cf. Chapter 1 for further explanation.

40 Cf. Post, "Complexity and conflict", 241-265, 247.

41 Cf. Post, "Complexity and conflict", 247-248. Cf. Barnard, Cilliers and Wepener, Worship in the Network Culture, 13; 74-76.

42 Reinder van Dijk, RKк broadcasting company, interview by Mк, March 2012. Also cf. the aim of production company Eye2Eye Media that I mentioned in Chapter 1. 
in Gouda this was able to create a certain atmosphere of trust that the city could participate in an event that would not turn out to be an explicitly religious happening. This was important because of the separation of church and state, which the city council took very seriously. Because of this separation, by their own account, Gouda decided to engage not on the level of content, but solely in facilitating the event:

Our task really was to facilitate and to supply and to make available: the square; the town hall; the people; the cooperation with the police; safety. That was our part. (...) Helping a particular target group or a religious group - that would really be impossible. If you do that you are crossing the line. ${ }^{43}$

The separation of church and state was a matter of serious concern for the city of Gouda. It came as no surprise, therefore, that the city council was not amused when, in the course of the media campaign unleashed by the broadcasting companies prior to the performance, The Passion was portrayed as a missionary event.

And all of a sudden, Syb (who was to play the role of Jesus, MK) had his coming out as a believer. (...) And they started to use a kind of word that I can't remember exactly, but because of that word, what it boiled down to was that The Passion was to persuade non-believers, and it became a kind of mission thing too... And then we thought: no! (...) Eventually, our alderman brought this to the attention of the producer in an extra meeting and said that this was not the approach that we had agreed upon. It was supposed to be more open and broader. And this turned out to be very helpful. ${ }^{44}$

To the city of Gouda, the physical, musical and ritual space that would be created through the performance of The Passion was not intended to serve any kind of missionary purpose. The city council insisted that The Passion would be presented as an event open to all, not as a means to evangelize nonbelievers. The contestation here regarded the tension between imposed meaning and the open character of the event; unambiguity versus multi-diversity; 'experience the story of Jesus, who died for you too' versus 'just come and ascribe to The Passion the meaning you like', to put it bluntly. This example again

43 Stout and Olieman, interview, February 2012.

44 Stout and Olieman, interview, February 2012. 
demonstrates that The Passion was a social space where several parties fought to make their own dominant meaning heard.

The tension that arose can be related to what Post describes as the ambiguity surrounding the basic sacrality of a ritual space. ${ }^{45}$ This ambiguity relating to the basic sacrality of a place has been a theme in Christian tradition from the outset, as, according to Post, it has emphasised the encounter with God, and has always been critical of the binding of God to any single place. This is why, from the perspective of the production company and the Christian broadcasting companies, The Passion could easily be performed in the open. Yet, the market square was incontestably a place set apart for the performance, it was claimed, and, when in the preparation process the word missionary was used, and the performer in the role of Jesus was revealed as a Christian, the space was once again "reclaimed from its surroundings, (... and) maintained in its status of being separate". 46 This set apart character of the sacred space presented the city council with a problem, as they - in their own view - were not facilitating a Christian event, but an event that would contribute to the positive outlook on the city.

\section{Conclusion}

A spirituality of dwelling in late-modern societies has developed into a spirituality of seeking, and the sacred does no longer grow on trees, but is rather something to be negotiated, recognised, found, discovered, and encountered at times. ${ }^{47}$ What is considered to be sacred is dynamic; it results from processes of the attribution of meaning to, and experience of, practices and objects. As a consequence, the sacred can be found anywhere. In this chapter we discussed three examples in which different interests and meanings conflict show how The Passion in Gouda was a spatial practice that, for a period of around 90 minutes, led to the creation of a site which was simultaneously both sacred and contested. The examples demonstrate that physical, musical and ritual spaces never have simply one meaning and always have multiple meanings ascribed to them. These meanings are fluid; they come into being through spatial practice. Multiple meanings can exist side by side, but sometimes also lead to contestation. The Passion in Gouda is an example of a spatial practice that,

45 Post, "Complexity and conflict", 244-245.

46 Post, "Complexity and conflict", 244.

47 Cf. Wuthnow, After Heaven, 3-4. 
for a while, turned the market square into a site which was ambiguous and multi-dimensional but nonetheless also sacred. Whether and, if so, how God may be found in ambiguous and multi-dimensional spaces and practices in a post-Christian, post-secular context, is a question worthy of further theological reflection. 


\section{Side Light: Locus Iste. A Meditation}

Locus iste a Deo factus est. Inaestimabile sacramentum irreprehensibilis est.
This place was made by God,

a priceless sacrament;

it is without reproach.

In my teens I was part of a small chamber choir. I have fond recollections of Wednesday evenings in the empty church, with its Roman and gothic architecture, in which we practised some of the loveliest pieces of choral music that I have had the chance to sing. Among the pieces I recall us rehearsing is Anton Bruckner's well-known gradual Locus iste ('This place', WAB23). Bruckner (1824-1896) composed the motet for the dedication of the new cathedral's Votivkapelle in the Austrian city of Linz in September 1869. ${ }^{1}$ The composition is based on the biblical narrative of Jacob, in which Jacob lies down to sleep at Bethel and has a dream, as a consequence of which he then identifies the place where he has slept as sacred ground. In Genesis 28,17 Jacob exclaims: "How awesome is this place! This is none other than the house of God, and this is the gate of heaven". Bruckner uses a more elaborate textual form for his motet, incorporating Jewish pseudepigraphal textual material, and the form which he uses is also known as the Latin gradual for the dedication of a church in the Roman Catholic liturgical tradition. Bruckner thus connects the ideas that 'this place was made by God' with a church building that, through its consecration, was to become a priceless sacrament. Ever since I became acquainted with the piece, I have been impressed by this very fine musical miniature, and the way in which Bruckner has used harmonic and melodic movements to set to music that particular moment when Jacob, to his surprise, recognizes a particular, ordinary place as sacred. This place is 'a Deo factus': made by God. The sacred is at the same time both identified by Jacob and God-given.

The surprise experienced by Jacob seems crucial to me. It suggests that blissful occurrences that we don't see coming, whether they be things we learn,

1 Alan Howie, "Bruckner and The Motet", in The Cambridge Companion to Bruckner, Cambridge Companions to Music, ed. J. Williamson (Cambridge: Cambridge University Press, 2004). DOI: 10.1017/CCOL9780521804042.006.

(C) MIRELLA KLOMP, 2020 | DOI:10.1163/9789004442948_007

This is an open access chapter distributed under the terms of the CC BY-NC 4.olicense, Klomp - 978-90-04-44294-8 
actions, unexpected results, or the amazing sensation that things have developed differently than we had expected, are a part of the process by which we identify the sacred. I tend to think that surprise is somehow always a part of it: the experience of the sacred is never entirely the result of a process that we have initiated and completed, but has aspects that seem to come to us from an 'outside' source, and which we do not fully control. This surprise may not always be a pleasant surprise however. It is also possible that the sacred might be found in negative things that occur to us (the story of the passion and crucifixion is the best example of this), in obnoxious things, uncomfortable experiences and in the hideous results of what we produce, know, or believe.

A Sunday evening in September 2012. The church choir that I am part of has sung Evensong in the Oude Kerk ('Old Church') in Amsterdam city centre, in the heart of what is known as the 'Red Light District'. We have celebrated the feast of the dedication of the church, that was consecrated in 1306, by singing Psalms and hymns and Bruckner's motet Locus iste. After evensong, I leave the church through the tower entrance to arrive at the square where window brothels, bars, cannabis and tattoo shops, and residential houses surround the church building. It is impossible not to catch a glimpse of the big breasts of the scarcely clothed sex workers who sit behind their windows. Every week, a local worshipping community gathers in this place to seek the face of God, at a time when people just outside of the building are watching soccer matches on big screens in bars, getting drunk whilst loudly slurring their chants of support or, at a distance of less than 20 metres from the church, having paid-for sex. Traces of God can occur in the silliest, the most surprising and the most vulnerable places: not only in a church building or in worship, but also - maybe even more so - between the sheets where sex is an economic product sold and bought instead of a practice of love. I hum while looking for my bike, and go home. Irreprehensibilis est. Even this place is an excellent place for God to become present.

Jacob, in Genesis 28 , is on his way from Beersheba to Harran. He has left his own land after a conflict with his older brother Esau, whose birth right and blessing he has stolen, and now he is travelling in a foreign land as a stranger and as a guest. Having gotten himself into trouble he is now a man on the run. I use his journey as a metaphor for the times in our lives in which we are, voluntarily or involuntarily, moving away from a place where we are no longer 
able to stay. A time when we are moving away from people with whom we can no longer live, work or even be together in the same space. A time when brothers and sisters do not manage to live up to the good and pleasant situation in which brothers and sisters dwell together in unity (Ps. 133:1). A time when we find ourselves in serious conflict. But it can also serve as an image for situations in which for some reason our professional positions have become untenable, for times of war, or for times when we leave existing structures behind (friends or family members, particular religious practices or images of God) in order to transition into a new phase. There are many different reasons for people to leave a place or flee from a situation, to go on a journey, or because of which they find themselves running into a foreign land.

Such journies come with uncertainties that make us feel vulnerable, and in those uncertainties, we may hang on to the things we hold particularly dear, just like Jacob does. When he reaches a certain place, he decides to spend the night there, and takes one of the regular, ordinary stones that he finds there, puts it under his head, and lays down to sleep. He then has a dream in which he sees a stairway which is rooted on the earth but whose upper end reaches up into heaven, with angels of God ascending and descending upon it. It seems to me that the angels feature in the dream in order to point towards Jacob's religious disposition: on his journey through a strange land, he is holding onto God. In the dream, our attention and the attention of Jacob is drawn to the upper end of the stairway. Apparently, Jacob has clear expectations of the place in which God dwells. But our attention is immediately steered right back down to the earth: Jacob does not find God upstairs but, unexpectedly, downstairs, right beside him. When we search for God, we may find God in an unexpected place. When Jacob wakes up, he recognizes the very place where he slept as a place where God dwells and, in astonishment, identifies it as the house of God: Bethel. The ordinary stone that he had used as a pillow becomes, at the same time, a sacrament: it is transformed into a sign to others of God's encounter with him.

Bruckner's composition employs stark musical imagery. The motion in the first section of his motet beautifully reflects the traffic of the angels on the stairway - descending on 'Locus iste', leaping sky-high at (the second) 'a Deo factus est', and gracefully ascending upwards as the choir sings 'inaestimabile sacramentum'. The same harmonic movement is then heightened further by a combination of transposition, an enhanced dynamic and the cumulative effect of repetition. Every time I hear or sing the piece, I am struck by its sense 
of forward motion. It is as if the sacred is never found straight away, never without some kind of intervening time or space, but only after movement, whether that movement be turbulent or inspiring in nature. In Genesis, Jacob is brought to a state of amazement and awe only after the elapse of a period of time in which angels ascend and descend upon the stairway. Bruckner's composition seems to suggest a rather orderly flow of angelic traffic, but this writing may well have been a deliberate attempt to suggest a feeling of rest and order: a few months after the first performance of the motet, the First Vatican Council was convoked as a response to the turmoil of a world in which Christian belief and the church as an institution had difficulties finding a place. In our own lives too, a transitional journey can sometimes be quite chaotic, and can also take some time. Those who have at some point been in such a situation may recognize the feeling that it seemed to take forever, or to lead nowhere: such a journey can sometimes consist of huge struggles. Anyone who has felt lonely or godforsaken for some reason, has been in serious conflicts or who, in whatever way, has gone through the darkness of death, may be familiar with the annoyance that certain phases simply last too long. Bruckner's threefold repetition of the words 'irreprehensibilis est' in the middle section of the motet is set as a stepwise chromatic descent, which is beautiful, but which almost feels too easy for me. When, after a journey through strange land, you find God in an unexpected place, then that may also come with negative experiences, with struggle, anger and frustration. Amazement and awe are wonderful, but one might also feel the need to throw some dishes.

The motet ends with a low final chord. Jacob identifies the strange soil, the foreign land through which he travels, where he is not at home and is uncertain of his safety, as the gate of heaven. This is a complete surprise: it is precisely when he is on the run, in the greatest misery which he has caused himself, that God meets Jacob. And Jacob recognizes and meets God. It might be precisely in the greatest distress, the deepest agony, the greatest dispute, that God encounters us and we encounter God.

When we undertake new quests for God in our own time and situation, we are travellers on journeys into strange lands. Our processes of sacred meaningmaking are not always neat and smooth: for many people the sacred no longer grows on trees, but is rather something to be recognised, discovered, and also negotiated. I like to interpret the narrative of Jacob at Bethel as a narrative which opens up the possibility that God appears not only in locations that we like or appreciate, but also in locations where we least expect it or places that 
we find dreadful. If you think that church is stuffy and "high church tradition" utterly boring, do not be surprised that God may live even in bread and wine. If you think of the church building as the preeminent place in which to encounter God, do not be surprised that God shows up to meet people in the streets. If you feel that the passion should be celebrated solemnly, do not be surprised that God casually pops up at a glitzy event. If you think of God as a being too sacred to engage with the mundane, do not be surprised to find God sitting next to people on the couch as they watch a dazzling passion show with their feet on the coffee table and eat cocktail nuts. God can be found in silly and surprising locations, and might even prefer to appear in broken places, places of conflict, of opposing interests, and of controversy and dispute. 


\title{
Playing with the Sacred: A Ludic Practice
}

\author{
With Marten van der Meulen
}

\begin{abstract}
A joke [in the passion narrative] is awesome now and then ... after all, this is a spectacle that connects people. But we should not want to include pleasantry that nauseates our Christian supporters. We have to find a balance between the show-character and the seriousness of the narrative.
\end{abstract}

REINDER VAN DIJK (producer for KRO-NCRV), March 22, 2017

(interview by $\mathrm{MK}$ )

While doing participatory observation on the Vismarkt square in the city of Groningen at this fourth edition of The Passion in 2014, my colleague Marten van der Meulen and I both had one eye on our smartphones to see what kind of messages people were posting under the hashtags \#passion and \#tp14 on Twitter. ${ }^{1}$ Amongst the diversity of topics addressed, which included the role of religion, comparisons with previous editions, choice of songs, performance and performers, and expectations that were or were not met, a particular kind of tweet stood out: the humorous ones. People on Twitter played around with jokes, ironic messages, wordplay and other playful messages related to all different aspects of The Passion. Their tweets touched, among other things, on the show, the biblical narrative, the performers, the songs, the square and the

1 This chapter is derived in part from an article published as Mirella Klomp and Marten van der Meulen, "The Passion as ludic practice", Journal of Contemporary Religion 32, no. 3 (2017), 387-401. DOI: 10.1080/13537903.2017.1362879. Author's contributions in this chapter are as follows: I wrote the introduction and the section 'Religious Changes in Late-modern Societies, with the exception of the summary of the work of Ammerman. In the section 'The Passion as Ludic Practice', Van der Meulen wrote the first subsection, the second subsection was written by me. The online ethnographic fieldwork underlying the section 'The Passion as Ludic Practice' was performed by Van der Meulen and myself: we both collected and analysed the data. Together we wrote a draft for the concluding section, which I then revised for the purpose of publication in this book. 
people in the audience. Humour is inherent to social network applications, as scholars in various disciplines have demonstrated. Late professor of sociology and communication Brenda Danet, for example, in 2001 argued that "Cyberspace is often anarchic, playful and even carnivalesque". ${ }^{2}$ Indeed, although digital media are also used for serious discussions and the communication of (real and fake) news, the broad conversational maxim is 'keep it light/fun'. ${ }^{3}$ The Passion seemed, in this sense, to be an object of human play like any other. After we had drawn each other's attention to the abundance of humour, the jokes that were part of the narrative of the play started to stand out. It appeared that, in the changing religious landscape of this late-modern network society, the Christian narrative of the passion has become a subject of playful acting.

'Play' thus struck us as a notion that might enable us to move beyond the religious-secular dichotomy that has dominated theories of religion for decades. ${ }^{4}$ Whilst, during the period in which secularisation theories flourished, lines between religious and secular practices were considered to be rather fixed, the adequacy of this divide has more-recently been contested in various studies of religion and has become a much-debated topic. ${ }^{5}$ Scholars have generally come to acknowledge that these lines are blurring. Modern life is characterised by continuous change, the world has become liquid. ${ }^{6}$ The question of whether we identify ourselves as religious or non-religious may no longer be relevant, now that identity has come down to "stopping being what one is and turning into someone one is not yet". ${ }^{7}$ New media contexts in particular seem capable of evoking, what philosopher Jos de Mul calls, processes of 'ludic self-construction'.

2 Brenda Danet, Cyberpl@y. Communicating Online (Oxford/New York: Berg, 2001), 8.

3 Ana Deumert, "The performance of a ludic self on social network(ing) sites", in The Language of Social Media. Identity and Community on the Internet, eds. Philip Seargeant and Caroline Tagg (Basingstoke/New York: Palgrave Macmillan, 2014), 23-45, here 23.

4 A similar suggestion has been made by André Droogers in his book Religion at play. A Manifesto (Eugene OR: Wipf and Stock, 2014), 45. In this chapter we push the intervention by elaborating concrete examples from the case of The Passion to demonstrate how this works.

5 Cf. for example Jose Casanova, "The Secular, Secularizations, Secularisms", in Rethinking Secularism, eds. Craig Calhoun, Mark Juergensmeyer, and Jonathan Van Antwerpen (Oxford: Oxford University Press, 2011), 54-74; John Seed, “'Secular' and 'Religious'. Historical Perspectives", Social History 39, no. 1 (2014), 3-13; Benjamins, "The Postsecular and Systematic Theology", 116-128.

6 Bauman, Liquid Modernity; Zygmunt Bauman, Liquid Life (Cambridge: Polity Press, 2005).

7 Bauman, Liquid Life, 8.

8 Jos de Mul, "The game of life. Narrative and ludic identity formation in computer games", in Handbook of Computer Game Studies, eds. Joost Raessens and Jeffrey Goldstein (Cambridge, MA: The MIT Press, 2005), 251-266. 
In this chapter we argue that public ritual practices with obvious Christian roots can provide a playing field in which people from a late modern postChristian, post-secular society are able to deal with religion. ${ }^{9}$ We claim that 'play' is an excellent concept to understand and show how this works. Therefore, we ask the question: how does the concept of 'play' help the understanding of public ritual practices such as The Passion event in Dutch society? By studying current public ritual performances from the perspective of play, in combination with media theory and play and game studies, we aim to contribute to the discussion on the way in which religion is changing in late-modern (European) societies.

We begin by discussing André Droogers's theory of play in religion and Nancy Ammerman's notion of sacred consciousness, which both point to people's hermeneutical faculty for dealing with the sacred in their lives. ${ }^{10}$ In liquid modern cultures, this faculty is, time and again, addressed and applied in creative, playful ways. ${ }^{11}$ We relate this to the global ludification of culture a theory developed by Valerie Frissen et al. who argue that 'play', propelled by new technologies, today influences all domains of our culture. ${ }^{12}$ Relating these theories to our case, we present three significant examples from our empirical data, showing how the characteristics of 'play' are worked out in The Passion. Lastly, we draw the conclusion that religion does not escape the influence of a global ludification of culture. ${ }^{13}$ Contemporary Dutch society offers space for religious ludism in rituals like The Passion which trigger people's hermeneutical faculties for dealing with the sacred. In ludic culture, people play with a Christian religious narrative that otherwise seems to be mostly irrelevant.

As mentioned above, passion plays were first performed in the Middle Ages during Lent, particularly in Roman Catholic Western Europe. Today they are still regularly performed throughout the world, mainly in countries where Roman Catholicism has a strong presence, e.g. the Philippines and Brazil (cf. Robin Leaver, "Passion Play", in The Cambridge Dictionary of Christianity, ed. Daniel Patte (Cambridge: Cambridge University Press, 2010), 926). The religious landscape in these cultural contexts is significantly different from the religious landscape that forms the scenery in this monograph.

10 André Droogers, Play and Power in Religion: Collected Essays (Berlin: De Gruyter, 2012); Nancy Tatom Ammerman, Sacred Stories, Spiritual Tribes. Finding Religion in Everyday Life (New York: Oxford University Press, 2014).

11 Bauman, Liquid Modernity; Bauman, Liquid Life.

12 Valerie Frissen et al., eds., Playful Identities. The Ludification of Digital Media Cultures (Amsterdam: Amsterdam University Press, 2015).

13 Another relevant example on the dynamics of religion and ludification is the Church of Fools (later renamed St Pixels). Cf. Tim Hutchings, Creating Church Online. Ritual, Community and New Media (New York: Routledge, 2017), esp. Chapters 4 and 6. 


\section{Religious Changes in Late-Modern Societies}

Late-modern network cultures in the global era are characterised, among other things, by processes of individualisation, fragmentation and interconnectedness, reconstruction of 'self' and 'identity', challenges to tradition and power, continuous reflexivity and flexibility. ${ }^{14}$ The consequences of this cultural backdrop for religion have been discussed by Callum Brown and, for the Netherlands, by Peter van Rooden.

In his study The death of Christian Britain, Brown argues that the decade of the 196os marked a "moral metamorphosis", which transformed the UK from a society with a shared Christian discourse into a society with a "truly secular condition". ${ }^{15}$ Although the religious dynamic in the Netherlands is quite different from that of the UK, the key insight of Brown is similar to what Van Rooden describes. Van Rooden has argued that Dutch Christianity crumbled apart during the massive cultural changes of the 196os, caused by and resulting in a move toward a "reflexive and expressive self". ${ }^{16}$ Previously, people had understood themselves as part of a self-evident ritual order and, when that changed, their religious participation withered away. ${ }^{17}$ Due to depillarisation, the typical top-down ideological authority structures of Dutch society were eroded away and many people lost their religious affiliation or showed more leniency, reflexivity, and choice in their beliefs. ${ }^{18}$ Without question, the changes in the religious landscape since the 196os have been massive. Yet we disagree with Brown that what we experience today is a truly secular society.

At this point, we turn to the recent work of Nancy Ammerman, who introduces the term 'sacred consciousness', as an attribute which many individuals possess, whether or not they are affiliated with religion. ${ }^{19}$ In essence, she

14 Cf. Anthony Giddens, The Consequences of Modernity (Cambridge: Polity, 199o). Bauman, Liquid Modernity; Brian Heaphy, Late Modernity and Societal Change. Reconstruction Social and Personal Life (London: Routledge, 2007).

15 Callum G. Brown, The Death of Christian Britain. Understanding Secularisation, 1800-2000, Christianity and Society in the Modern World (London/New York: Routledge, 2001), $190 ; 1$.

16 Van Rooden, “Oral History", 548. Cf. Chapter 2.

17 Van Rooden argues that one of the differences between the UK and the Netherlands is that the latter did not have a common Christian discourse, but that Dutch society was separated into different pillars which all had their own discursive ritualised ways of living. Van Rooden, "Oral History", 545-546.

18 Willem Frijhoff and Marijke Spies, Dutch Culture in a European Perspective: 1950, Prosperity and Welfare (Assen: Uitgeverij Van Gorcum, 2004), 325.

19 Ammerman, Sacred Stories, 292. 
describes the hermeneutical faculty people possess which enables them to identify the sacred in their lives. Ammerman, alongside others who take a situational approach to the sacred, ${ }^{20}$ places the ability to mark something as sacred or religious in the individual, instead of identifying neatly separated domains as either religious or secular. She argues, for example, that the workplace is not entirely a secular domain. People have the ability to tell stories about work in which they interpret events as having sacred or religious meaning. This makes 'sacred consciousness' essentially hermeneutical. Ammerman argues that "when sociologists study religion, it is this sacred consciousness that is at the heart of our enterprise". ${ }^{21}$ She draws on the work of Durkheim to connect the individual aspects of contemporary religion to communal forms such as congregations, which still have a large influence on people's ability to give mundane events sacred meaning. In our view, the term 'sacred consciousness' also helps to describe how people relate to public events, such as The Passion.

Paying attention to this hermeneutical and individual moment in the construction of religion and/or the sacred is by no means new, but it has become more important in the broader debate on the consequences of late modernity for religion. A liquid modern society is "a society in which the conditions under which its members act change faster than it takes the ways of acting to consolidate into habits and routines", according to Bauman. ${ }^{22}$ In liquid modern life, the sacred is to be found and identified by individuals in new situations and events, again and again. Bauman argues that liquid moderns are accustomed to 'trying on' identities, and that they practise 'spiritual sampling' or the 'taste-testing' of spiritual ideas and practices. ${ }^{23}$ Liquid modern life constantly appeals to people's ability to give meaning to events in their life, including their sacred consciousness. Individuals need to make their own choices, and Ulrich Beck therefore speaks of "institutionalized individualization". ${ }^{24}$ The individual needs to choose a "god of one's own". 25 Considering the fact that the religious field is littered with religious players and sacred forms, such as The Passion, individuals "must negotiate various religious institutions and sacred

\footnotetext{
20 Cf. Chapter 4 where we described sacralising as a human interpretative activity.

21 Ammerman, Sacred Stories, 293.

22 Bauman, Liquid Life, 1.

23 Bauman, Liquid Life, $28 ; 7$.

24 Ulrich Beck, A God of One's Own. Religion's Capacity for Peace and Potential for Violence (Cambridge: Polity, 2010), 95 .

25 Beck, A God of One's Own, 95.
} 
forms in their everyday lives". ${ }^{26}$ This fits with Brown's and Van Rooden's arguments about the transformation of religion which is caused by and results in the rise of the reflexive and expressive self. However, it does not lead to secularity per se, but rather to a flexible, ever changing, and confusingly varied playing field of religious experimentation.

\section{Religion and Play}

The hermeneutical faculty that Ammerman describes has a strong link with the concept of play, particularly in religious and ritual practices. The relation between religion and play has, over time, been discussed at length by various scholars. ${ }^{27}$ For the purpose of this chapter, we focus on the theory of Droogers, a cultural anthropologist of religion who draws extensively on the work of Victor Turner, in particular on liminality and ritual. For Droogers, play is a practice that enables people to create meaning and understand the world around them. His theory illuminates how people play by connecting together

26 See Gerardo Marti and Gladys Ganiel, The Deconstructed Church. Understanding Emerging Christianity (Oxford: Oxford University Press, 2014), 179ff. for an extended discussion of Beck's work in relation to other scholars of religion. The term 'sacred forms' comes from Lynch, The Sacred in the Modern World, 5, 15-17.

27 Anthropologists, sociologists as well as ritual and liturgical scholars have written about play and religion. Cf. the following publications (in chronological order): Romano Guardini, The Spirit of the Liturgy. Trans. Ada Lane (London: Sheed and Ward, 1937 [1935]); Johan Huizinga, Homo Ludens. A Study of the Play-Element in Culture (London/Boston/Henley: Routledge and Kegan Paul, 1949). Originally published as Proeve eener bepaling van het spel-element der cultuur (Haarlem: H.D. Tjeenk Willink \& Zoon., 1938). Ronald L. Grimes, Ritual Criticism. Case Studies in its Practice, Essays on its Theory (Waterloo, Canada: Ritual Studies International, 2010 [1990]); Bernard Lang, Sacred Games. A History of Christian Worship (New Haven: Yale University Press, 1997); Paul Post, "Speelruimte voor Heilig Spel", in Over spel. Theologie als drama en illusie, eds. Herman Beck, Rein Nauta and Paul Post (Leende: Damon, 2000), 139-167; Marcel Barnard and Paul Post, eds., Ritueel Bestek. Antropologische kernwoorden van de liturgie (Zoetermeer: Uitgeverij Boekencentrum, 2001); Brent Plate, "Religion is Playing Games: Playing Video Gods, Playing to Play", Religious Studies and Theology 29, no. 2 (2010), 215-23o; Jaco Hamman, "Playing", In The Wiley-Blackwell Companion, ed. Miller-McLemore, 42-50 (in which he discusses play in/and practical theology; also see the bibliography of that chapter); André Droogers, Play and Power in Religion; André Droogers, Religion at play; Marcel Barnard et al., "Play/Function", in Worship in the Network Culture, eds. Barnard, Cilliers and Wepener, 245-274; Heidi Campbell and Gregory Grieve, eds., Playing with Religion in Digital Games, Digital Game Studies (Bloomington, IN: Indiana University Press, 2014); Stef Aupers, "Spiritual Play: Encountering the sacred in World of Warcraft", in Playful Identities, eds. Frissen et al., 75-92; Simone Heidbrink, Jan Wysocki and Tobias Knoll, eds., "Religion in Digital Games Reloaded. Immersion into the Field", Online - Heidelberg Journal of Religions on the Internet 7 (Heidelberg: University of Heidelberg, 2015). 
two realities simultaneously. He defines play as "the capacity to deal simultaneously and subjunctively with two or more ways of classifying reality". ${ }^{28}$ The term 'subjunctively' is taken from Turner's work and refers to the fact that people can imagine other worlds and other realities 'as if' they are real. ${ }^{29}$ In play, according to Droogers, people can hold two different sets of rules simultaneously and "as long as the game lasts, one set only is valid and creates its own reality. Yet even during the game itself there is the consciousness that when the game is over the other set will prevail". ${ }^{30}$

Droogers gives a decidedly hermeneutical pitch to his theory of play. Putting two realities together simultaneously helps people to explore new ways of seeing things and allows them to participate in a different reality without completely committing to it. After play, people can withdraw from the reality that was explored if it did not meet expectations, or commit more strongly to it if it did. ${ }^{31}$ Crucial to Droogers' theory is the idea that play is not just a cultural phenomenon but also a human capacity, it is an element of humanity's dealing with the world. Play in his view is a human faculty that shapes religious and cultural repertoires and forms.

\section{Ludification of Culture}

'Play as a human capacity' is also the starting point for Frissen et al. in an important cross-disciplinary study on the ludification of digital media cultures. ${ }^{32}$ Whilst the authors clearly consider ludification as a result of play, it could

28 Droogers, Play and Power, 81.

29 Victor Turner, "Frame, Flow and Reflection: Ritual and Drama as Public Liminality", Japanese Journal of Religious Studies 6, no. 4 (1979), 465-499, here 465-466. Also: Victor Turner, The anthropology of performance (New York: PAJ Publications, 1988), 169.

$30 \quad$ Droogers, Play and Power, 81.

31 In line with his theory, Droogers even coined the term methodological ludism as an approach to studying religion: when playing, whether a believer or a non-believer, a researcher can better understand what religion is and means. Or, to use Versteeg's words: "Researchers play along with their informants in a radical attempt to reach verstehen (understanding), without converting to the informant's reality". Peter Versteeg, "Playing Religion? Experience, Meaning and the Ludic Approach", in Anton van Harskamp et al., eds., Playful Religion. Challenges for the Study of Religion (Delft: Eburon, 2006), 97-108, here 98. We have not used Droogers's particular methodology, but see Kim Knibbe et al., "Fieldwork on Ritual. Understanding Through Participation", in Methods for the Study of Religious Change. From Religious Studies to Worldview Studies, eds. André Droogers and Anton van Harskamp (Sheffield: Equinox Publishing, 2014), 87-110, for an application, discussion, and further extension of this theory. 
also be seen as the corollary or epiphenomenon of other large-scale developments such as consumerism or late capitalism. ${ }^{33}$ Nevertheless, Frissen et al. offer an interesting exploration of the relationship between play and identity construction, updating Johan Huizinga's famous theory of Homo Ludens. They emphasize the role of digital media technologies that increasingly shape how people relate to the world, other people, and themselves (as list to which we add their relationship to God/the sacred, as we will elaborate below). Scholars in cultural studies argue that, from the 1960s onwards, playfulness has increasingly become a feature of our culture. We may even speak of a 'ludic turn' or, in the first decade of the 21st century, a global 'ludification of culture. ${ }^{34}$ Today, play permeates every cultural domain, ranging from leisure time, including activities such as shopping, game shows, computer games, internet, tablet and smartphone use, and amusement parks, to more serious fields, such as education (gamification), work (that should mainly be enjoyed), politics (ludic campaigning) and warfare (computer games such as war simulators). ${ }^{35}$ We live in a ludic culture where playfulness is no longer restricted to childhood (as if that was ever strictly the case), but has instead become a lifelong attitude that is clearly visible. Bauman argues that "The mark of postmodern adulthood is the willingness to embrace the game whole-heartedly, as children do". ${ }^{36}$ Hence and this is the same conclusion De Mul arrived at in his research on computer games - our identity has become a ludic subject. ${ }^{37}$ It may be no surprise that ludism occurs in a liquid modern world. When identities are tried on and spiritual sampling is practised, even our religious identity has become a ludic subject.

33 On ludo-industry and ludo-capitalism cf. Julian Dibbell, "The Chinese Game Room. Play, Productivity, and Computing at Their Limits", Artifact 2, no. 2 (2008), 82-87. Cf. also Pedro Rey, "Gamification and Post-Fordist Capitalism", in The Gameful World. Approaches, Issues, Applications, eds. Steffen P. Walz and Sebastian Deterding (Cambridge (MA): The MIT Press, 2014), 277-295.

34 On 'ludic turn', cf. Judith Thissen, Robert Zwijnenberg, and Kitty Zijlmans, Contemporary Culture. New Directions in Art and Humanities Research (Amsterdam: Amsterdam University Press, 2013), 12. Cf. also Joost Raessens, "The Ludification of Culture", in Rethinking Gamification, eds. Mathias Fuchs et al. (Lüneburg: Hybrid Publishing Lab, 2014), 91-114, here 109-111, http://gamification-research.org/2014/o6/edited-volume-rethinking -gamification-out/. Last accessed October 31, 2019. On 'ludification of culture', cf. Frissen et al., Playful Identities, 9.

35 Frissen et al., Playful Identities, 9.

36 Zygmunt Bauman, Life in Fragments. Essays in Postmodern Morality (Oxford: Blackwell Publishers Ltd., 1995), 99.

De Mul, "The game of life", 26o-261. 
Technology and digital media play an important role in this ludic turn. Frissen et al. propose four characteristics of digital media: (1) multimediality: a multitude of means of expression that lead to a multisensory experience as well as a shared digital code (software permeates almost every aspect of our lives), (2) virtuality: immersive experiences, evoked by simulation technologies, and metaphorical spaces created by communication networks, where the real and the virtual are connected, (3) interactivity/participation: users can intervene in a meaningful way within the representation itself, either through designed choices and procedures or by participating beyond the object, (4) connectivity: Facebook is the best-known example of this; it is a site where people connect around individuals, but also around topics or events, in communities. ${ }^{38}$ Furthermore, Frissen et al. propose that digital media, seen as playful practices, are characterised by four ambiguities: (a) reality and appearance are interrelated, (b) freedom and force: we can play and we are beingplayed at the same time, (c) determination and change: the final phase always becomes outdated by the arrival and claims of newer media, (d) individuality and collectivity: the identity of individual media in a media landscape where different media systems are converging. ${ }^{39}$

In summary, we may say that, in a globally ludifying culture, in which institutionalised Christianity has crumbled and authority structures have collapsed, the reflexive and expressive self has risen and people have more space for leniency, reflexivity, and choice in their beliefs. In such a culture, people's sacred consciousness as well as their capacity to deal simultaneously and subjunctively with two or more ways of classifying reality is constantly being spoken to. In this cultural context, a public ritual based on the Christian passion narrative in the Netherlands can become highly popular. What insights does the notion of play offer to our understanding of public ritual practices similar to The Passion event in Dutch society?

\section{The Passion as Ludic Practice}

As we have already discussed, the organizers of the show use popular Dutch hit songs and put the lyrics into the mouths of the main characters. When sung as a duet by Jesus and Judas, a love song normally sung by a couple is imbued with a new and/or different meaning, adding an extra layer. The format consists of a

38 Frissen et al., Playful Identities, 22.

39 Frissen et al., Playful Identities, 28-29. 
constant interplay between two or more realities, and the audience are invited to do the same. In the following sections, using both the lens of Droogers's theory and the ludification theories offered by Frissen et al., we will analyse how play works in and around the performance. We first present some general observations about this ludic practice and then further elaborate by discussing three striking examples. In each example, both the organizers and the public are players. We describe the realities that are simultaneously being connected, the (digital) media which are involved, the characteristics and ambiguities that play a role, and the broader issues that are at stake.

\section{General Observations}

Throughout The Passion event, broadcasting companies and the producer, as well as the public, all engage in various media at the same time. Of course, the stage action that is broadcast live is the most crucial part. In addition, before, during, and after the event the organizers intensively use their Facebook account in order to build a community of 'likers', thus stimulating connectivity and their Twitter account @thepassion in order to stimulate interactivity, frequently employing visuals and videos that combine polished images, sounds, and texts (multimediality). The public engages in social media independently or in response to the organizers' social media activities. The organizers generate media attention for those who are to be that year's performers with interviews on www.thepassion.nl and on $\mathrm{TV}$ and radio talk shows (multimediality) and invite people to respond through social media, for instance, by employing share-and-win-techniques (interactivity). The procession that becomes part of The Passion bears all four characteristics of playful digital media practices. It combines the physical walk through the streets, the broadcast of the procession, and the virtual procession via the Internet (multimediality). It connects the real and the virtual by giving the offline procession an online counterpart, based on a software application (virtuality). It enables people to type their motivations into the textbox, thus generating participation (explicit interactivity). The way in which these motivations pop-up on people's devices during the virtual procession, on the screen on the stage, and in the live-broadcast connects people and their play (connectivity).

In short, as a multimedia event, The Passion appears to have all the characteristics of a ludic practice as identified by Frissen et al. ${ }^{40}$ In other words, the digital media in this case clearly offer users new opportunities to play with a Christian narrative. We will now go deeper by examining three specific examples. 


\section{The Dutch Queen of Plastic Surgery in the Role of the Servant Girl}

Humour, and more specifically irony, is a form of play that is regularly applied in and around The Passion..$^{41}$ Our analysis of tweets shows that many people make jokes about The Passion, for example, "They should make a book about this \#tp1 $5^{\text {"42 }}$ - a simple joke, as, of course, that book already exists in the world outside the play. Before The Passion had even begun, several people had already tweeted that they were looking forward to humorous comments. Many people actively wait for the 'fun' element of The Passion, as alluded to in the tweet "I am ready for it! Next 2.5 hours I am not approachable. Lots of fun! \#Passion \#Passion2015 \#passion15 \#thePassion". ${ }^{43}$ Strikingly, many Dutch comedians lie in wait to play with The Passion. Yet, it is not just the public that makes jokes around The Passion: the organizers also employ humour in The Passion. In the 2015 edition, the scene in which Peter denies Jesus starts with "the Dutch icon of plastic surgery", ${ }^{44}$ Marijke Helwegen, in the role of a servant girl, saying that she recognizes Peter as one of the friends of Jesus. ${ }^{45}$ She walks a Chihuahua dog to whom she says: "Come, Goliath, come and pee..." The actress was reverse typecast for the role of servant girl, as the organizers chose a woman in her sixties who constantly tries to retain her youthfulness and so was the tiny dog, who was named after Goliath, the biblical giant. Here, the reality of the biblical characters of servant girl and Goliath were combined with the realities of, respectively, the contemporary beauty industry and the practice of keeping tiny dogs as pets. This scene immediately evoked various comments on Twitter. Some tweets showed that people appreciated this playful combination of realities, while other tweets were negative, and some people were obviously provoked into play themselves by making jokes on Twitter. ${ }^{46}$ These are all clear examples of beyond-the-object-interactivity (people participating within the culture of the object), they did not directly influence the

41 Humor, which is related to play in the sense that it also combines different realities, is a research topic of its own that goes beyond the scope of this chapter. We confine ourselves to mentioning humour as one possible form of play.

42 Passion-Archiver excel sheet \#4871. All quotations from the digital media in this chapter are originally in the Dutch language and were translated into the English by the authors.

43 Passion-Archiver excel sheet \#4666.

44 "Marijke Helwegen", Wikipedia The Free Encyclopedia, July 12, 2016. https://nl.wikipedia .org/wiki/Marijke_Helwegen. Last accessed May 10, 2020.

45 "The Passion 2015", NPO Start, EO/KRO, video, 1:34:०0, at 55:o8, https://www.npostart.nl/ the-passion-2015/O2-04-2015/VPWON_1240591. Last accessed October 31, 2019.

46 E.g. appreciation: Passion-Archiver excel sheet \#1897; discontent: "too much" \#19o9, "bad combination" by @[pastorı], tweet, April 2, 2015 at 1.19 p.m.; "too much of a parody" by $@$ [pastor2], tweet, April 2, 2015 at 1.21 p.m., jokes: Passion-Archiver excel -sheet \#2918, \#2891, \#3419. 
performance on the stage or the live broadcast, but contributed to the interactive discussion via digital media. ${ }^{47}$ Here the public played and was at the same time played by the organizers; thus we recognize the ambiguity of freedom versus force, as discussed by Frissen et al. ${ }^{48}$

The use of the Dutch queen of plastic surgery as the servant girl is just one example of a scene in which the producers deliberately connected contemporary and biblical realities so as to result in a humorous effect. In the deliberate application of humour in the representation of the Christian passion narrative, the 'as if'-character of play that combines different realities enables players to either withdraw from the reality that is explored or to commit more strongly to it. For some people, this created a distance between themselves and the narrative: a relativisation that is potentially useful when a religious story is staged that runs the risk of being ridiculed or rejected ${ }^{49}$ Since the production and broadcasting companies aim for high viewing figures, this distance is employed to make the event accessible to a broad and diverse public. Yet, in a secularising country where practices of spiritual sampling are important, it also enables people to commit to the reality that even Marijke Helwegen can play a part in the narrative on Christ. ${ }^{50}$ Apparently, the God-story can even be about you or me or anyone. The ludic passion practice can lead people to try on a religious identity and see how it fits. Religious identity thus no longer has to be seen as a fixed given but, rather, can take on something of a ludic character.

Whilst this scene did result in some people withdrawing from the reality being explored, the point here is that humour opens possibilities for players to

47 Interestingly, Wikipedia has a more elaborate definition of 'second screen' than the Oxford Dictionary (cf. Chapter 3, footnote 13), which emphasises its potential to generate an online conversation around the content: "A second screen involves the use of a computing device (commonly a mobile device, such as a smartphone or tablet) to provide an enhanced viewing experience for content on another device, such as a television. (...) The use of a second screen supports social television and generates an online conversation around the specific content". "Second Screen", Wikipedia The Free Encyclopaedia. https://en.wikipedia.org/wiki/Second_screen. Last accessed May 10, 2020.

48 Frissen et al., Playful Identities, 28.

49 The distance or relativisation (including the assessment of its appropriateness) is not unequivocal, as became clear in a Twitter discussion between two Protestant pastors. Regarding the participation of Marijke Helwegen and a couple of other celebrities, $@$ [pastor1] spoke of "stylistic ruptures that undermined the narrative", tweet of April 2, 2015, whereas@[pastor2] said in response to @[pastor1] that, in her opinion, there was too much parody included in this version, tweet of April 2, 2015.

50 Passion-Archiver excel-sheet, tweet \#1963: "Marijke Helwegen in the Passion \#amazing \#tp15". 
play, that is, to see or experience things they had not seen or experienced before. It addresses the human hermeneutical faculty for dealing with the sacred in one's life, and, vice versa, to see one's life in light of the sacred.

\section{After His Arrest Jesus Christ Appears in an Iconic Orange Jumpsuit}

Some elements of the show derive new meaning from images and topics that have previously been seen and discussed in the media. A particularly prominent example of this is the orange jumpsuits of Barabbas and Jesus. Since the first edition in 2011, Jesus and Barabbas have, every year, worn orange coveralls when they appear before Pontius Pilate as detainees (see figure 11 in the next chapter). The desirability of choosing orange has been much debated by the public from the start but, in 2015 in particular, it became a hot topic. It reminded the public, as demonstrated by several tweets, of the Isis practice of killing prisoners in orange coveralls. A few weeks earlier, photos of ISIs terrorists in black clothing killing Coptic Christians in very similar orange coveralls on a Libyan beach had reached the front pages of the Dutch news media. On the morning of the performance, 2 April 2015, the news media broke the story of the killing of the 147 Kenyan students by ISIs. Many people referred to this event in tweets about The Passion. Interestingly, in previous years, people had associated the coveralls with the prisoners in Guantanamo Bay, an association that was probably intended by the organizers who, from the very first edition, had been keen on connecting The Passion to contemporary debates. ${ }^{51}$

Comments about The Passion in digital media prominently featured discussion about Islam. On the second screen, a Muslim texted his personal motivation for walking in the virtual procession:

I walk along as a Muslim in this world much is rotten which I cannot help but I can walk along with the cross and thereby contribute to a peaceful world 'cause in the end we are all human. ${ }^{52}$

The following tweet combines - with an intentionally humorous or perhaps even ironic tone - discussion of Islamisation with what is happening on the screen and 'on the couch' where people watch the show:

$5^{1}$ The prevalence of these kinds of comments shows that a religious play can engender public reflection and discussion about contemporary topics, a point that Turner already stressed. "Public reflexivity takes the form of a performance", he argued. Cf. Turner, "Frame, Flow and Reflection", 465. Also see Victor Turner, From Ritual to Theatre. The Human Seriousness of Play (New York: Performing Arts Journal Publications, 1982), 13.

$5^{2}$ Motivations virtual procession-excel sheet (2015) \#6084. Document obtained via broadcasting company EO. 
The fact that more than 4 million people watch a public crucifixion eating popcorn and crisps offers possibilities for islamisation \#tp15. ${ }^{53}$

This is another example of how, in digital media, different realities are playfully combined at once: the reality of the show itself, the reality of the people sitting in front of a TV screen, the reality of the current discussion about Islamisation in the Netherlands, and the reality of the violence which is associated with Islam and of which people had seen many examples on TV in the weeks preceding the show. The storm in a teacup brought about by the orange jumpsuits on social media strikingly reflects the ambiguities of freedom and force, and of reality and appearance that surround digital media. Part of the public resented the choice of the costumes in this play. They had the freedom to play along, yet they could not escape the organizers' design. In this case, the design troubles them and they have no influence. The interactivity of digital media (one of its characteristics), however, enables them critically to comment on the design choice of the costumes via social media.

\section{An Accused Actor in the Role of Barabbas}

*spoiler alert* The inhabitants of Enschede will again crucify Jesus. Despite the fact that @daveroelvinkı plays Barabas [sic] \#thepassion. ${ }^{54}$

One topic that provoked a torrent of tweets was the participation of Dave Roelvink in The Passion as Barabbas. Dave is the son of Dries Roelvink, a celebrity folk singer (although many consider him as a B-list celebrity). Dries' son was relatively unknown until he achieved national notoriety in August 2014 when a sex video appeared on YouTube of an orgy in which Dave had participated. A woman figuring in the video brought a lawsuit against Dave and also accused him of theft. In the tweet quoted above, different realities are referred to. First the "*spoiler alert" is a typical joke because many people already know that Jesus is the one who will be crucified. "The inhabitants of Enschede" is a reference to the place where The Passion was held, which brings together, itself, a combination of realities, because originally, of course, it was the people in first-century Jerusalem who crucified Jesus. The tweet expresses amazement that Barabbas again is 'off the hook', "despite the fact that @daveroelvinkı plays Barabas", which suggests that the tweeter thinks

53 Passion-Archiver excel-sheet, tweet \# 3285 .

54 Passion-Archiver excel-sheet, tweet \#6228. 
that Dave Roelvink is a much better candidate for crucifixion than the real Barabbas ever was.

People were surprised that Dave Roelvink appeared on the show as Barabbas. Several members of the media picked up this sentiment. De Telegraaf, the largest national newspaper in the Netherlands, held an online poll asking people whether they thought it was alright that someone of disrepute (although Dave Roelvink had not been convicted yet) participated in The Passion. Remarkably, $72 \%$ of the people who responded to the poll were against the participation of Dave Roelvink. ${ }^{55}$ The Passion organizers responded with an official statement:

Exactly by giving this role to Dave and the resistance that this evokes, The Passion shows the injustice/unfairness of the fact that Jesus was condemned instead of Barrabas [sic]. ${ }^{56}$

The following day, the popular TV show "RTL Late Night" picked up the topics of the orange coveralls and the participation of Dave Roelvink and questioned the director about the reasons why the organizers had selected Roelvink. the director paraphrased the official statement. This is another example of the 'convergence' that is part of the ambiguity of individual media versus collective media: there is "an ongoing process or series of intersections between different media systems", in this case, TV, the internet site of a newspaper, and Facebook. ${ }^{57}$

This example can be seen as a public thematisation of a moral topic, i.e. whether someone of disrepute should have positive public recognition on a TV show, even when playing a criminal. There are hints of religious elements too. Part of the public disapproval seems to be related to the fact that Dave Roelvink participated in a religious event, which apparently still has a sacred quality. Interestingly, the discussion did not take place within a single site, but across different, converging media. This demonstrates the continuing possibility for religion to engender and channel public debate.

55 See De Telegraaf. "Eo de mist in met Dave Roelvink", April 1, 2015. https://www.telegraaf .nl/entertainment/837013/eo-de-mist-in-met-dave-roelvink. Last accessed May 10, 2020.

56 Quotation from the statement made on the Facebook page of The Passion organisation, April 1, 2015 at 1.21 a.m. The statement was repeated in a number of social media and in official TV interviews.

57 Frissen et al., Playful Identities, 29. They quote Henry Jenkins, Convergence culture. Where old and new media collide (New York: New York University Press, 2006), 282. 


\section{Conclusion}

Returning to the central question of this chapter, we argue that in late modern society people engage in public ritual practices which have Christian roots in a playful manner, thereby sampling and tasting what is offered. This sampling and tasting are enabled by various digital media that both the organizers and the public employ. In doing so, the public relates to Christian and religious narratives that for a large portion of these people otherwise seem to be mostly irrelevant. This ludic practice, through various digital and non-digital media, offers participants the possibility to engage in an event about the story of the suffering and death of Jesus without necessarily committing themselves wholesale to a religious cosmology or morality. The 'as-if' character, which, for many people in a secularising society, comes with play, legitimizes their participation in an event based on a religious narrative. In employing digital media, they also engage in the religious narrative by playfully connecting it to broader societal and moral issues: societal concerns regarding 'Islamisation' (particularly related to violence by Isis that has recently been on the news), and the moral issue of people accused of wrongdoings being (un)worthy to play a role in the event. This result is in line with the observation by Stef Aupers who, in an article on spiritual play, argues that online game play provides "an unacknowledged epistemological avenue to interact with the sacred and to contact the ultimate values that, Max Weber (1919) argued, retreated from modern life". ${ }^{5}$ Understanding The Passion as play thus explains how people's hermeneutical faculty for dealing with the sacred in the world can be addressed. A recommendation for future research is to further investigate the relation between this public ritual and meaning-making on the part of individuals: what meaning do they ascribe to this ludic practice? Can this be seen as 'sacred' and, if so, in what way?

People's dealings with Christian ritual repertoire, symbols and narratives do not escape the influence of the global ludification of culture, as we have shown, and are strongly influenced by digital media. They acquire multimedial, virtual, interactive and connective traits and are affected by the ambiguities of playful practices. Therefore, we should be wary of seeing Dutch society as truly secular or of seeing an event like The Passion as a return to religion. Ludic practices such as The Passion may be recognised as events where the antithesis between the religious and the secular grows weak or even disappears.

$5^{8}$ Aupers, "Spiritual Play", 76. Aupers here refers to Max Weber, "Science as a vocation". in From Max Weber: Essays in sociology [1919], eds. Hans H. Gerth and C. Wright Mills (London: Routledge, 1948), 129-156. 
Offering a playground or an interface, these events trigger (or even induce) people's hermeneutical faculties for the sacred in a way which is very similar to Ammerman's 'sacred consciousness' and Bauman's 'trying on identities'. Today, religious identity is often not a fixed but a playful phenomenon. The concept of play helps to resolve the paradox that, in a (still) secularising country such as the Netherlands, a performance of the core Christian narrative can be so popular. 'Play' makes the religious-secular dichotomy irrelevant: institutionalised religion in late modern Dutch society is undeniably in decline but, at the same time, religion, and engagement with the sacred, are ludic practices that are very much alive. 


\section{Side Light: @deusludens. A Twitter Thread}

I am the Lord of the play. I created you by teasingly blowing into your nostrils. Ever since you came to life, we have playfully interacted, genesising together, enjoying the becoming of things, forms, the world. Stop questioning if I exist or not. I become real as we play $1 / 10$

I created you in my image and likeness; you are a playing species. The fun is that as you ludically transform elementary actions into something beyond survival, you make sense of the world. What is play except finding truth? What other than humankind's perpetual becoming? 2/10

No, play isn't always fun. After that forbidden-fruit-affair you often quit our play, starting your own games, ready to decide (in my name) who was out, who had lost the right to play along, who knew the rules. Your inclination to act as game leader can be slightly tiresome $3 / 10$

Verily, mixed feelings were always part of play, both in Jesus' crucifixion (my most ludic move) and in 21st century digital play. Jesus died for you to live in my reality. Scroll your way through his Passion and feel uneasy, o denizens of teh interwebz: confusion is vital $4 / 10$

BTW, the playfulness of Web 2.0 and socials are closer to me than you might think. The virtual ('non-tangible' like me) and the real are connected, on the internet as in Jesus. Your multisensory digital experiences are incarnate stuff that playfully tie me to your world 5/10

Corrupted play - Auschwitz, Aleppo, all evil - remains play. Play is tricky for you as it is for me. You may cheat. You have cheated. If I lose my credibility you may want to quit. Do me a favour: unless lives are at risk, seek lightness, don't take yourselves too seriously $6 / 10$

Playfulness gives life in abundance, Mary knows why! But was her delight in me but enthusiastic foreplay for a cruel game of high stakes poker on the cross? There, going all-in was matched by what? Darkness? The game is on, graciously, you're playing the role of your life! $7 / 10$

Our play combines two worlds: the reality you live in and my world-to-come. Whenever you encounter people giggling, laughing, dancing, musicking, jok- 
ing, storytelling, protesting, feast your eyes! Their play may perform a seethrough perspective on my envisioned kingdom $8 / 10$

I still let you play for a bit, but on my day, there will be an Everlasting Closing Party. Humour, improvisation and 'oh and ah' will abound. There will be royal entertainment transcending the joy of any other play. Jest to experience a foretaste of my grand finale $9 / 10$

Lastly: I playingly imagined our play, y'all. These rules are not set in stone I am open to negotiation and may even embrace criticism, lol. Come on, let me know what you think. Cheerz! \#slowthread \#homoludens2.o \#deusludens \#divineplay \#10x280characters \#discuss 10/10 


\title{
Dealing with Society's Secular Self-Understanding: A Reflexive Practice
}

\author{
With Marten van der Meulen, Erin Wilson and Anita Zijdemans
}

I am not a person of faith. And I have wondered whether or not it is hypocritical to take on a role in an event based on a Christian narrative, when I would be unwilling to participate in an Islamic show.

quote from a singer who played one of the main characters in The Passion, March 2018

(from personal conversation with $\mathrm{MK}$ )

In societies as volatile and fluid as those of late-modernity, norms and values are constantly subject to challenge. ${ }^{1}$ Whilst central institutions are rapidly losing their authority and power, these norms and values are being (re-)negotiated in new ways. As a consequence, the self-understanding of contemporary nations - how "we" would describe "our" society/culture/way of life - is continuously being re-shaped and re-calibrated. While individuals can reflect upon their own feelings, reactions and motives (or examine these in the consulting room of a therapist) before adjusting their behaviour or views accordingly,

1 This chapter is an updated and revised version of an article previously published as Mirella Klomp, Marten van der Meulen, Erin Wilson and Anita Zijdemans, "The Passion as Public Reflexivity: How the Dutch in a Ritual-musical Event Reflect on Religious and Moral Discussions in Society", Journal of Religion in Europe 11 (2018), 195-221. DOI: 10.1163/18748929 -01102007. The different authors' contributions to this chapter are as follows: I revised the original article for the purpose of publication in this book. The 'Background'-section was largely written by Erin Wilson. In the section 'The Passion as Public Reflexivity', the subsection 'The image of Jesus' is based on a research report written by Anita Zijdemans on the basis of the ethnographic data that she collected during fieldwork in Enschede in 2015. The subsections 'Jesus in an orange jumpsuit' and 'The morality of the actors' are based on online ethnographic fieldwork, with data collected and analysed by Marten van der Meulen and myself. 
societies examine themselves in and through the public sphere. According to anthropologist Victor Turner, plural reflexivity is public reflexivity, which means that public events offer a way for societies to portray themselves, understand themselves and then act upon themselves. ${ }^{2}$ This raises the question of whether a televised Christian event such as The Passion reveals anything about the 'secular' self-understanding of the Dutch. How do the Dutch look at their national identity when it comes to religion/secularity and morality, and what processes of deep examination and, perhaps, transformation does this evoke? Our inquiry in this chapter can be encapsulated in the following central question: how does a public event based on a Christian narrative engender public reflexivity around contemporary religious and moral debates?

This question has become particularly pressing as nominally secular and liberal politicians have in recent years started to dally conspicuously with Christian culture, narratives and symbols, reframing all kinds of secular values as part of what they often eagerly call 'the Judeo-Christian culture.. ${ }^{3}$ Their usage of Christian religion in their nationalist discourses is not neutral: it takes place in a climate of religious polarisation and rising Islamophobia. ${ }^{4}$ In fact, in Dutch 'secular' culture an appreciation for 'Judeo-Christian culture' often

2 Victor Turner, "Frame, Flow and Reflection", 465.

3 Ernst van den Hemel, "The Dutch War on Easter. Secular Passion for Religious Culture \& National Rituals", Yearbook for Ritual and Liturgical Studies 33 (2017), 1-19, here 1-2. Van den Hemel states, in his article, that he has observed "the outlines of nationalist discourse that combines secular and religious dimensions in new and influential manners. Secular political discourse increasingly embraces religion, making it an object of policy and intervention in the process". Van den Hemel, "The Dutch War on Easter", 3.

4 Academic research shows that in the most secularised countries religious polarisation is stronger. See Egbert Ribberink, Peter Achterberg and Dick Houtman, "Religious polarization: contesting religion in secularized Western European countries", Journal of Contemporary Religion 33, no. 2 (2018), 209-227. DOI: 10.1080/13537903.2018.1469262. The results of an online poll of people's attitudes regarding different religions held by research company YouGov, show that Western respondents in particular had less favourable views of Islam than they did of other religions (both in countries with a Christian majority and in countries that used to have a Christian majority). See Rogers de Waal, Joel, "Western/MENA attitudes to religion portray a lack of faith in common values", YouGov, February 3, 2019. https://yougov.co.uk/topics/international/articles-reports/2019/o2/o3/westernmena -attitudes-religion-portray-lack-faith-. Last accessed May 10, 2020. Regardless of whether the Netherlands is classified as secularised country, Islamophobia in the Netherlands has increased since the year 200o, according to sociologist of religion Sipco Vellenga in his article "Anti-Semitism and Islamophobia in the Netherlands: concepts, developments, and backdrops", Journal of Contemporary Religion 33, no. 2 (2018), 175-192. DOI: 10.108o/13537903.2018 .1469257 . 
goes hand in hand with a dislike for 'Islam'.5 Media (whether printed, broadcast, or online) do not play a neutral role here: they have the power to allow some voices to be heard and to silence others, to cover and frame some incidents and ignore others. ${ }^{6}$ This chapter will show that media have a strong voice in current societal debates, including those about religion, and that they thus have an influence on collective communication around the secular selfunderstanding of a society more generally.

The term 'public reflexivity' was coined by Victor Turner as part of his argument that all societies have their own public meta-social rites, which are "performed at crucial points in the turning year, or on occasions of collective crisis when a whole society faces a major change". ${ }^{7}$ In this chapter we employ Tuner's theory to try to understand the societal and public dynamics surrounding The Passion in a Dutch religious landscape currently subject to processes of transformation. After elaborating on Turner's theory, we sketch the background to current public debates surrounding religion and post-secularity in Europe and the Netherlands. We then focus in on three particular themes that we encountered during our empirical research on The Passion: the particular characteristics of Jesus that the organizers sought to convey, the complex meaning-making which took place around the design decision to use the orange costumes (an example which we described in Chapter 5 , but which we here discuss from a different viewpoint), and the suitability of the actors playing Jesus and Barabbas to perform in The Passion in relation to their past 'immoral' behaviour. We will use our analysis of these topics in order to demonstrate how performances like The Passion offer spaces in which the Dutch can reflect publicly on important identity issues, such as the role of Christian heritage and the visibility of Muslims in a supposedly secular age.

5 Van den Hemel, "The Dutch War on Easter", 10.

6 In her PhD thesis on the representation of Muslims on Dutch television in the past sixty years, Andrea Meuzelaar reveals how the television coverage of Islam and Muslims "has resulted in a rigid iconography that has made Islam instantly recognizable, but has also reduced Islam to a handful of emblematic images that now carry connotations far beyond their initial significance". Andrea Meuzelaar, "Seeing through the archival prism. A history of the representation of Muslims on Dutch television" (PhD diss., University of Amsterdam (Faculty of Humanities), 2014), 134. She concludes that in the years 2000-2010, "television coverage of Dutch Muslims became very much fixated on the issues of fundamentalism and terrorism in the Netherlands, the radicalisation of young Muslims, radical imams, the position of Muslim women, headscarves and veiling". Meuzelaar, "Seeing through the archival prism", 119.

7 Turner, “Frame, Flow and Reflection", 466. 


\section{Exploring Uncertainties around National Identity}

As far back as 1979, Turner observed that there is a close relationship between drama and reflection: a group communicates to itself about itself in various ways, verbally (through speech) and non-verbally (through "gestures, music, dancing, graphic representation, painting, sculpture, and the fashioning of symbolic objects"). ${ }^{8}$ Ritual and drama, in Turner's view, are forms of plural reflexivity, and since drama is a public event, plural reflexivity often means public reflexivity. Drawing on folklorist Arnold van Gennep's distinction between rituals performed at moments of life-crisis and rituals performed at crucial points in the turning of the year or during collective crises, Turner focuses on the latter: rituals which are public in character, which are performed for collectivities. This latter type of rite enacts aspects of 'ritual or status reversal', but also reveals the constant presence of a meta-language "that is, codes or presentation and expression which enable participants and spectators to realise just how far they have fallen short of or transgressed their own ideal standards, or even, in some kinds of ritual, to call those very ideals into question under conditions of sharp social change". ${ }^{9}$

These public meta-social rites, as Turner calls them, are often performed in village or town squares where they are visible to everyone, and they use every day spaces as their stages so as to 'consecrate' these spaces for the duration of a liminal and 'transitory' time-period. According to Turner, it could, slightly simplistically, be suggested that "for every major social formation there is a dominant mode of public liminality", and that there is therefore some kind of relationship between social processes and performative genres. ${ }^{10}$ When engaged in processes of self-reflection, a society sets up "a frame within which images and symbols of what has been sectioned off can be scrutinised, assessed, and, if need be, remodelled and rearranged"."11 According to Turner, what is put inside the frame is often considered to be sacred, and this is thereby separated from that which is 'profane', 'secular', or 'mundane'. Rituals have a scenario/score, and they mostly contain festive, joyful, and playful episodes and incidents: they are serious and entertaining, solemn and ludic at the same time. ${ }^{12}$ In stage drama - which is identified by Turner as a major reflective genre - authorship of scenarios is attributed to individuals. Nevertheless, stage plays are as much public as private modes of performance: they involve "ac-

\footnotetext{
8 Turner, "Frame, Flow and Reflection", 465.

9 Turner, "Frame, Flow and Reflection", 467.

10 Turner, "Frame, Flow and Reflection", 468.

11 Turner, "Frame, Flow and Reflection", 468.

12 See Chapter 5.
} 
tors, audience, producers, stagehands, often musicians and dancers, and, most of all, their plots and messages are communicated by various written and oral networks to a general public which varies in span and composition from society to society and from epoch to epoch". ${ }^{13}$ In stage drama, descriptive narrative and reflexive commentary are interwoven with one another. This kind of reflexivity is not only engaged in by the performers, but also by the author and the public. The author reflects, whereas the actors flow, ${ }^{14}$ and the audience is moved. ${ }^{15}$

Another conceptualisation of the sacred has been offered by Gordon Lynch. Like Turner before him, Lynch draws on Durkheim, in particular on his emphasis on the sacred and processes of sacralisation in daily life. In Lynch's view, the sacred consists of those things and events that are of ultimate significance to people. In society, there are sacred forms which serve as "specific instantiations of the sacred" in which "symbol, emotion, normative claims, ritual practice, and social collective" intersect. ${ }^{16}$ These sacred forms may be religious, but can also be secular, without any reference to transcendence. Lynch thus attempts to disentangle the concepts of the 'religious' and the 'sacred' that have often been confounded in social theory.

In their 2014 study of contemporary liturgical ritual, Marcel Barnard, Johan Cilliers, and Cas Wepener build upon the liminal theories of van Gennep and Turner, suggesting that:

[the renewal of liturgical ritual] moves between the established churches and their traditional liturgical forms, on the one hand, and less defined spaces, times and groups on the other hand. [...] Late-modern culture is also characterized by notions such as transformations, transgression, transcultural and border crossing. However, instability still - and ever more so - evokes the opposite notion and desired condition of stability, perhaps a consequence of a lack of late-modern cultural awareness. ${ }^{17}$

When brought together with these reflections, Lynch's argument becomes even more compelling: the sacred moves and is also to be found outside of the religious domain, both in liturgical rituals and in a range of other forms:

13 Turner, "Frame, Flow and Reflection", 486.

14 I.e., their "action follows action according to an inner logic which seems to need no conscious intervention on [their] part, [...] there is little distinction between self and environment, between stimulus and response, or between past, present and future". Quote from Turner, "Frame, Flow and Reflection", 490.

15 Turner, "Frame, Flow and Reflection", 490.

16 Lynch, The Sacred in the Modern World, 9 and 26, respectively.

17 Barnard, Cilliers and Wepener, Worship in the Network Culture, 65. 
it cannot be fenced in by religion. The Passion may therefore be considered to be an event that has become sacred not just because but also in spite of its underlying Christian religious narrative.

The Passion, seen as a contemporary form of longer-standing annual traditions of Passion performance, is a public ritual, performed for collectivities, as described by Turner. In the twenty-first century, such public rituals take shape in a culture that is influenced by mediatisation, by leisure time characterised by increasing eventfulness and hyperfestivity, by ludification, and by the aforementioned dynamics of religious polarisation. ${ }^{18}$ These developments do not simply pass us by without also having an effect both on religion and on religious practices. Thus, when translating Turner's theory for the circumstances of late-modern Dutch culture, we might say that The Passion points to what might be considered a dominant mode of public liminality in this society. ${ }^{19}$ The Passion demonstrates many examples of public reflexivity, not only in the performance itself, but also in the public domain, for example on television or on Twitter. The Passion can be seen as a meta-social ritual which Dutch society uses in order to explore its own uncertainties around national identity. In the twenty-first century, these uncertainties, among other things, relate to the question of the supposedly secular nature of the Dutch public sphere, and the rising visibility of religion, particularly Islam. The Passion can also be seen as a sacred form, since it takes place at the intersection between symbols, emotions, normative claims, ritual practices, and the social collective. Before we

18 On mediatisation, see Stig Hjarvard, The Mediatization of Culture and Society (London: Routledge, 2013); Stig Hjarvard and Mia Lövenheim, eds., Mediatization and Religion: Nordic Perspectives (Göteborg: Nordicom, 2012). On hyperfestivity, see Greg Richards, Leisure in the Network Society: From Pseudo-events to Hyperfestivity? (Tilburg: Tilburg University, 2010), esp. 13; cf. Paul Post, "Panorama der Ritual Studies: Trends und Themen der aktuellen Ritual Studies", Archiv für Liturgiewissenschaft (2013 [2015]), 139-181, esp. 164 where Post defines leisure culture as one of the fields where the sacred is found. On ludification, see Raessens, "The Ludification of Culture", 91-114. On polarisation and Islamophobia, see Ribberink, Achterberg, and Houtman, "Religious polarization"; Van den Hemel, "The Dutch War on Easter"; Vellenga, "Anti-Semitism and Islamophobia"; Meuzelaar, "Seeing through the archival prism".

19 Turner himself would have defined these events as 'liminoid'. This term indicates that modern events are, according to Turner, quite different from traditional ritual practices in pre-modern societies. He was, therefore, hesitant to use his theory of liminality and ritual in relation to modern societies. He looked instead for modern functional equivalents, which he called liminoid. This distinction has been criticised by others: the correspondence between pre-modern and modern ritual, especially when it comes to large public events, seems too great to warrant a different term. Sharon Rowe, for example, has argued that modern sporting events can rightly be described as liminal. See Sharon Rowe, "Modern Sports: Liminal Ritual or Liminoid Leisure", in Victor Turner and Contemporary Cultural Performance, ed. Graham St. John (New York \& Oxford: Berghahn Books, 2008), 127-148. We concur with her. 
dive deeper into The Passion itself, we want to first sketch some of the broader context regarding the role of public religion. In particular, recent debates surrounding post-secularity both in Europe and the Netherlands are relevant here.

\section{Background: From Secular to Post-secular in European Public Life?}

The secular character of contemporary European (and Dutch) society has been subject to wide and varied debate. This debate warrants some brief discussion in order to sketch the backdrop against which The Passion takes place and in order to bring the potentially fruitful contribution of Turner to bear on this debate.

Over the course of the last decades, a number of incidents have raised important questions regarding the validity of common assumptions regarding the secularisation of Europe. These incidents include debates over whether to include reference to a common Christian heritage in the European Constitution; unease over Turkey's potential membership of the EU; debates about the presence of religious symbols in the public sphere, in which Christian symbols are often classified as 'cultural heritage' whilst headscarves, turbans, and other objects are classified as 'religious'; rising concerns over the growing presence of 'radical Islam' in Europe; the refugee crisis, in which questions about the religious identity of refugees have become entangled with debates regarding security, the appropriate humanitarian response, and European social cohesion; and the so-called 'burkini ban' in France that has provoked major controversy in Europe and around the world. ${ }^{20}$ These incidents all suggest that Europe's secular character cannot simply be taken for granted. ${ }^{21}$

$20 \quad$ On the classification of 'cultural' and 'religious', see Lori Beaman, "Battles over Symbols: The 'Religion' of the Minority Versus the 'Culture' of the Majority", Journal of Law and Religion 28, no. 1 (2013), 141-157. On the refugee crisis, see Erin Wilson and Luca Mavelli, "The Refugee Crisis and Religion: Beyond Conceptual and Physical Boundaries", in The Refugee Crisis and Religion: Secularity, Security and Hospitality in Question, eds. Luca Mavelli and Erin Wilson (London: Rowman and Littlefield International, 2017), 1-22; The Economist. "Diverse, desperate migrants have divided European Christians", http://www.economist .com/blogs/erasmus/2015/o9/migrants-christianity-and-europe. September 6, 2015. Last accessed May 10, 2020; EU Observer. "EU states favour Christian migrants from the Middle East", https://euobserver.com/justice/129938. August 21, 2015. Last accessed 1 October 2019. On the 'burkini ban', see The Guardian, "France's Burkini Ban Exposes the Hypocrisy of the Secularist State", August 24, 2016. https://www.theguardian.com/commentisfree/ 2016/aug/24/france-burkini-ban-secularist-equality-muslim?CMP=fb_gu. Last accessed May 10, 2020.

21 Benoît Challand, "From Hammer and Sickle to Star and Crescent: The Question of Religion for European Identity and a Political Europe”, Religion, State and Society 37, no. 1 
José Casanova has claimed that the very formation of the European Union $(\mathrm{EU})$ is rooted in Christian thought and practice. ${ }^{22}$ Although the intimate relationship between Christianity and modern European identity is contested, ${ }^{23}$ Europe's secular nature is often emphasised over its relationship to Christianity, and the dominant narrative told about Europe's historical development is the successful separation of religion from politics and law in order to establish communities of peace and tolerance. ${ }^{24}$ An emphasis on a European 'Christian cultural heritage' over and against a seemingly growing and hostile Islam is a much more recent development which intersects with broader trends towards narratives of 'good religion/bad religion' in global politics. ${ }^{25}$

As part of the renewed interest in religion in European public life, the concept of the 'post-secular' has emerged as an attempt to make sense of this renewed presence. Erin Wilson and Manfred Steger have argued that the postsecular has been utilised both as a description of and as a response to the

(2009), 65-80; Elizabeth Shakman Hurd, The Politics of Secularism in International Relations (Princeton: Princeton University Press, 2008); Lucian N. Leustean and John T. S. Madeley, "Religion, Politics and Law in the European Union: An Introduction", Religion, State and Society 37, no. 1 (2009): 3-18; Francois Foret, "Religion: A Solution or a Problem for the Legitimisation of the European Union?" Religion, State and Society 37, no. 1 (2009), 37-50, here 38 .

22 José Casanova, "Religion, European Secular Identities and European Integration", in Religion in an Expanding Europe, eds. Timothy A. Byrnes and Peter J. Katzenstein (Cambridge: Cambridge University Press, 2006), 65-92, here 66.

23 José Casanova, "The Secular and Secularisms", Social Research 76, no. 4 (2009): 10491066, here 1058-1059; Leustean and Madeley, "Religion, Politics and Law", 4. Jeffers Engelhardt, for example, speaks about the historical imagery of a Christian Europe (Jeffers Engelhardt, "Arvo Pärt and the Idea of a Christian Europe. The Musical Effects and Affects of Post-Ideological Religion", in Jeffers Engelhardt and Philip Bohlman, Resounding Transcendence. Traditions in Music, Religion, and Ritual (Oxford: Oxford University Press, 2016), 215-231), whereas an author like Tom Holland claims that Christianity is intimately related to Western identity (Tom Holland, Dominion. The Making of the Western Mind (London: Little Brown, 2019)).

24 Jean-Paul Willaime, "European Integration, Laïcité and Religion", Religion, State and Society 37 , no. 1 (2009), 23-35.

25 Beaman, "Battles over Symbols". For a detailed discussion of the 'good religion/bad religion' narrative, see Elizabeth Shakman Hurd, Beyond Religious Freedom: The New Global Politics of Religion (Princeton: Princeton University Press, 2015). Vellenga, in a recent article on anti-Semitism and Islamophobia, concludes that: "In the Netherlands, the general level of the annual numbers of recorded incidents of anti-Semitism and Islamophobia has increased since 2000 and, at the same time, there have been significant fluctuations in the numbers of notified incidents per year. The fluctuations correlate to outbursts of violence in the Middle East and to acts of violence committed in the name of Islam in the West. The increase of anti-Semitism and Islamophobia relates to real, symbolic, and social threats experienced in the context of Dutch multi-ethnic society, changes in national identity, and trends in globalisation". Vellenga, "Anti-Semitism and Islamophobia", 187. 
apparently new context of public religion in which we find ourselves. ${ }^{26}$ Jürgen Habermas also uses the term in order to explain the continuing and, in some cases, revived presence of religion in secular European societies. ${ }^{27}$ Since the 1980s, and especially with the end of the Cold War and developments after $9 / 11$, it has become manifestly clear that 'religion' - variously understood, but usually framed in terms of personal belief systems, traditions, and institutions - is not dying out, contrary to the predictions of secularisation theory, but, rather, is taking on new significance in a range of alternative forms. ${ }^{28}$

The concept of the post-secular has met with significant critique, especially regarding the utility of the term as a description of the current European moment. ${ }^{29}$ Firstly, the prefix 'post' suggests that at one time Europe was 'secular' but that is has subsequently moved beyond this. ${ }^{30}$ Secondly, the emergence of the idea of 'secularism' and the 'secular' from out of Christian theology raises additional problems regarding the neutrality and universality of secularism and whether Europe has ever been 'secular' in the sense of being areligious. ${ }^{31}$ Indeed, understandings of the secular and secularisation have often rested on the assumption that secularisation is characterised by declining church attendance and declining belief in God. ${ }^{32}$ Yet, this assumes a highly Christian perhaps even a doctrinal ${ }^{33}$ - understanding of 'religion'. Indeed, in some cases,

26 Erin Wilson and Manfred Steger, "Religious Globalisms in a Post-secular Age", Globalizations 10, no. 3 (2013), 481-495, here 485-487.

27 Jürgen Habermas, "Religion in the Public Sphere", European Journal of Philosophy 14, no. 1 (2006), 1-25.

28 José Casanova, Public Religions in the Modern World (Chicago: Chicago University Press, 1994); Hurd, The Politics of Secularism; Mark Juergensmeyer, The New Cold War? Religious Nationalism Confronts the Secular State (Berkeley \& Los Angeles: University of California Press, 1994); Lucian Leustean and John Madeley, "Introduction: Religion, Politics and Law in the European Union", in Religion, Politics and Law in the European Union, eds. Lucian Leustean and John Madeley (London: Routledge, 2009), 1-16; Daniel Philpott, "The Challenge of September 11 to Secularism in International Relations", World Politics 55, no. 1 (2002), 66-95. See also Jonathan Arnold, Music and Faith. Conversations in a Post-Secular Age (Suffolk: Boydell and Brewer, 2019).

29 See, e.g., James A. Beckford, "Public Religions and the Postsecular: Critical Reflections", Journal for the Scientific Study of Religion 51, no. 1 (2012), 1-19.

30 Ahmet T. Kuru, Secularism and State Policies Towards Religion (Cambridge: Cambridge University Press, 2009).

31 Casanova, "The Secular, Secularity, Secularism", 54-74.

32 See, e.g., Steve Bruce, God Is Dead: Secularization in the West (Oxford \& Malden: Oxford University Press, 2002); Ken R. Dark, "Large-scale Religious Change and World Politics", in Religion and International Relations, ed. Ken R. Dark (London: Macmillan, 2000), 50-82.

33 This definition of religion, in which 'belief' is one of the main constituents, is often believed to have emerged out of the so-called Further Reformation and is frequently also connected to Anglo-Saxon Puritanism and German Pietism. The second reformation can 
secularisation has been defined as a decline in 'traditional Christian religiosity', not as a decline in 'religion' more generally. ${ }^{34}$ Furthermore, the categories of the 'religious' and 'secular' themselves have been demonstrated by numerous authors to be problematic. ${ }^{35}$ The rise of public non-Christian forms of religiosity, in particular Islam, in Europe in recent years has, to some extent, highlighted the way in which 'religion', and specifically 'Christianity', is not as separate from identity and politics in Europe as it was previously assumed to be.

Whether or not the idea of the 'post-secular' is considered to be an apt concept, the term nevertheless points to the contested nature of both religion and secularity in contemporary Europe. What it means to be religious (Christian/Muslim/...) and/or secular is indeed part of ongoing discussions in media, in politics, and in the personal sphere. In light of this, the popularity of events such as The Passion should be no surprise, especially not if they bring core societal topics of religion/secularity, such as the role of Christian heritage, the position of Islam in Europe, and the role of public morality to the fore.

\section{The Passion as Public Reflexivity}

Three controversial and striking issues specifically related to the topics of secularity and religiosity emerged during our ethnographic fieldwork over the course of $2015 .{ }^{36}$ Bearing Turner's theory of public reflexivity in mind, we decided to analyse interviews, photographs, and websites which referenced three particular related topics: the general character, demeanour, and appearance of

be understood as "the movement within the Reformed Church of the seventeenth (and eighteenth) century in response to the flattening of the faith and indeed to deepen and broaden the impact of the sixteenth-century Reformation. Its representatives urged with prophetic force the application of the Reformed doctrine to personal and public life as well as holiness in all areas of life". Herman Selderhuis, "The Further Reformation", in Handbook of Dutch Church History, ed. Herman Selderhuis (Bristol, CT: Vandenhoeck \& Ruprecht, 2014), 338-341, here 338.

34 See, e.g., Dick Houtman, Stef Aupers, and Paul Heelas, "Christian Religiosity and New Age Spirituality: Cross-Cultural Comparison", Journal for the Scientific Study of Religion 48, no. 1 (2009), 169-179.

35 See, e.g., Hurd, The Politics of Secularism; William T. Cavanaugh, The Myth of Religious Violence (Oxford: Oxford University Press, 2009); Talal Asad, Formations of the Secular (Stanford: Stanford University Press, 2003), as well as the previous chapter of this book.

36 Over the course of its history, between 2011 and 2019, The Passion has shown engagement with a number of current societal and also core political topics, such as the influx of refugees, life in a multi-cultural society, loneliness, and disasters which have had a high impact on cities; see Chapter 1 for discussion of the subsequent editions of The Passion that reflected these topics. 
Jesus in The Passion; the choice to have Jesus appear before Pontius Pilate in an orange jumpsuit; the character of the actors playing Barabbas and Jesus, in particular discussions related to the actors' (immoral) pasts. In what follows, we will discuss these topics consecutively on the basis of Turner's theory, relating them to current issues and (public) debates in Dutch society. The first two issues are further enriched by some late fieldwork material gathered after 2015 .

\section{An Image of Jesus}

It was the rejection of the first promotional photos portraying the Jesus figure that drew our attention to the issue of the image and character of Jesus. When asked about the image of Jesus which they wished to convey through the event, the remarkable first response from members of the production team was always that they did not have one particular image of Jesus in mind and, instead, that the image depended on the actor portraying Jesus, whilst the event itself is meant to leave room for audience interpretation. Yet, given that they themselves select the actor to play Jesus, there seemed to be some prior conception of the image of Jesus which exerted influence upon processes of decision-making, namely that of a tall, slim, white man with a moustache, a beard and long curly hair, ${ }^{37}$ the main physical features that determine the 'classical Jesus-look'. A man, also, who is honest and open. This is a very particular and distinct image of Jesus, with roots in Western visual culture. After the initial promotional photo shoots which were taken of members of the cast for the purposes of marketing the 2015 edition, the pictures portraying Jim de Groot in the role of Jesus were rejected - an incident which is highly revealing. De Groot's body language was considered to be not open enough, and thus to be unfitting, particularly in the photos that portrayed him standing with folded arms. "Jesus should instead have an open attitude. [...] I would like to have more pictures where he stands with his arms open, with an open attitude, reaching out to people, looking up (to heaven), etcetera". ${ }^{38}$ New photos had to be taken, and during the second photoshoot (at which we were present), we observed that "openness" and also "integrity" were keywords. It was important to the organisation that Jesus looked welcoming to all people. Aside from this,

37 In 2016, the singer who played the role of the Jesus character was not slim at all, and for this reason he was presented in the media as a "contested" person. See "Omstreden Martijn Fischer klaar voor rol van Jezus in The Passion", ShowNieuws, February 22, 2016, https://www.shownieuws.nl/video/clips/2016/omstreden-martijn-fischer-klaar -voor-rol-van-jezus-passion/. Last accessed May 10, 2020.

Anon., email to MK, fieldwork 2015. 


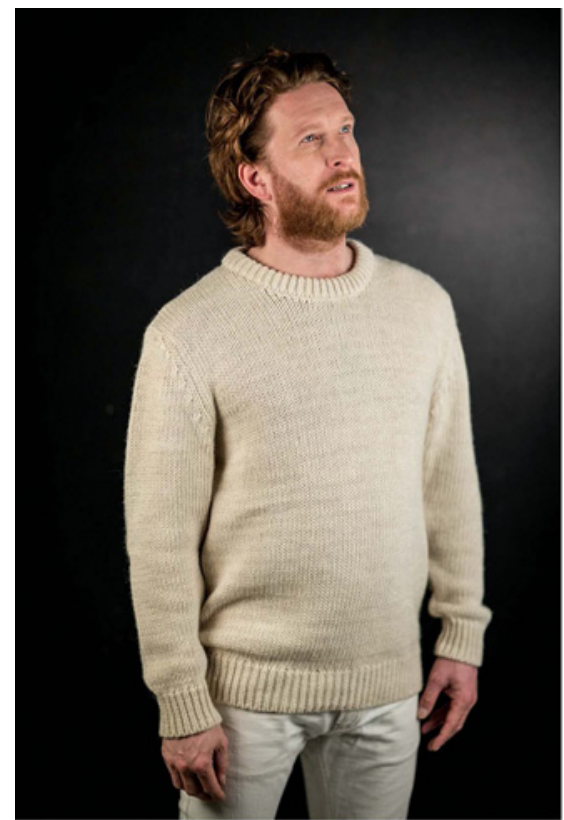

_Z6A4063@Hans-Peter van Velthoven.JPG

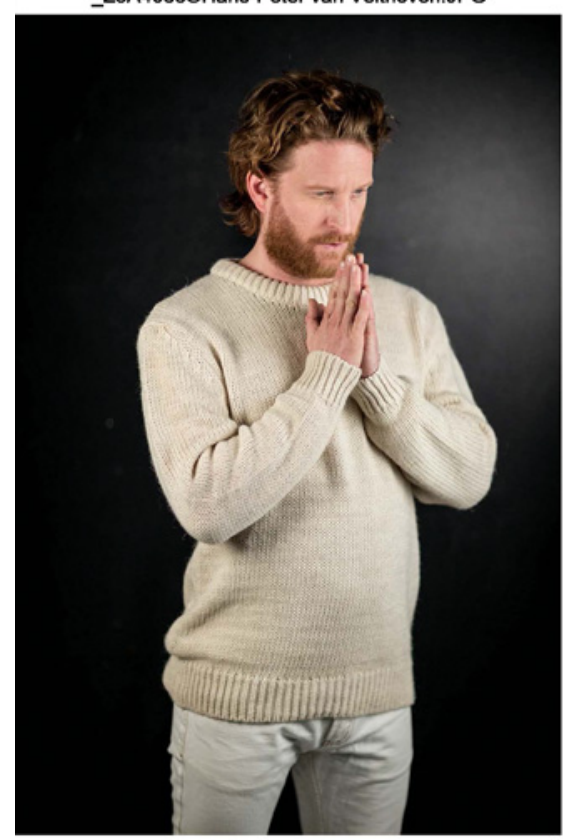

Z6A4065@Hans-Peter van Velthoven.JPG

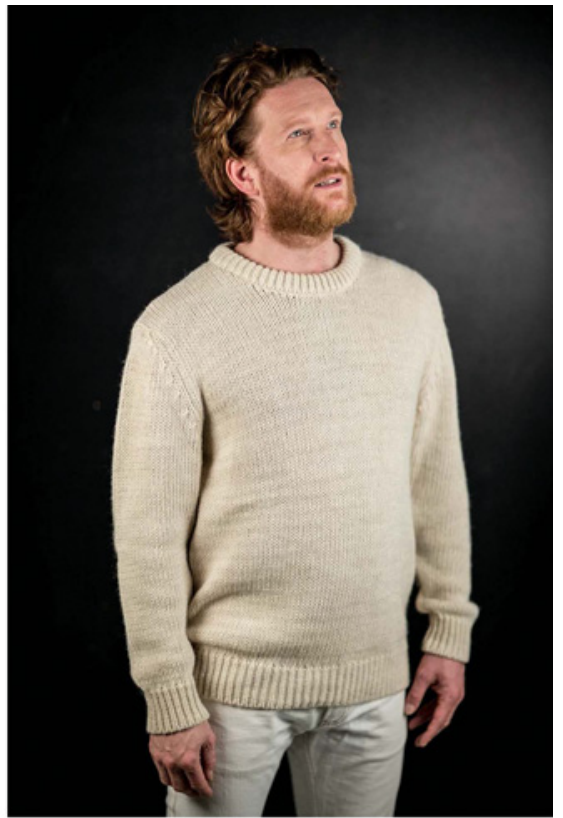

_Z6A40640Hans-Peter van Velthoven.JPG

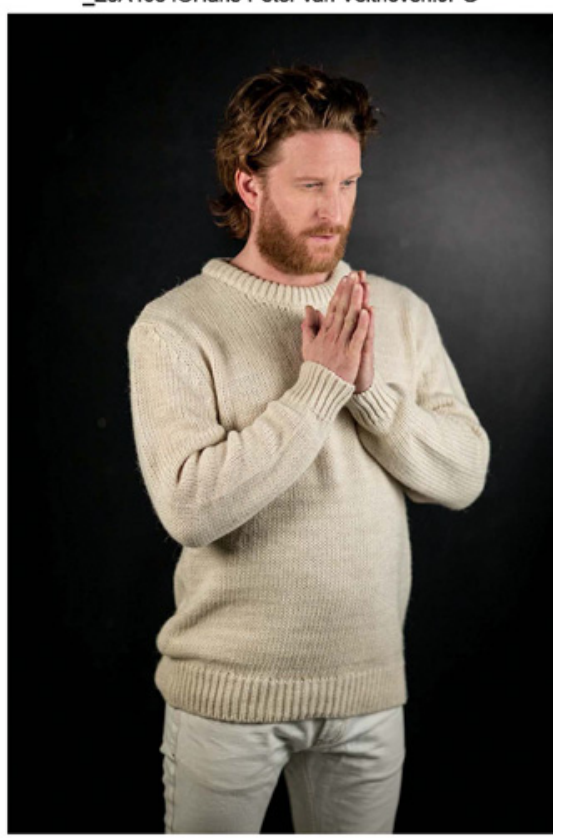

Z6A40660Hans-Peter van Velthoven.JPG

FIGURE 10 Pictures from the second photo shoot with Jesus, 2015 PHOTO: (C) HANS-PETER VAN VELTHOVEN 
it was deemed important that Jesus showed compassion and love. During the photoshoot, de Groot was told several times to make his expression softer in order to accomplish this. At the same time, several people in the production team added, in conversation with us, that openness and kindness were not enough: Jesus also needed to be strong, to be a leader, and not, as one of them put it, "a flunky". ${ }^{39}$ Several also remarked that de Groot looked like Jesus, but then quickly added that this was of course only intuitive, since 'we do not and cannot know what Jesus really looked like'. De Groot's hair and beard, in particular, were strongly associated with Jesus' appearance. This confirms that the organisers did indeed have a classical image of Jesus in their minds, which they brought with them into the production of The Passion, namely that of a white, Western (attractive?) guy. In the nine editions of The Passion which took place between 2011 and 2019, the appearance of the Jesus character rarely deviated much from this image. ${ }^{40}$ In an ethnically and culturally diverse society, the prevailing image of Jesus, with a few exceptions, generally resembles an autochthonous Dutch man. It seems that Western visual culture still influences the casting of the Jesus character in The Passion. As a result, Christianity is (again) actively linked to Dutch culture.

\section{Jesus in an Orange Jumpsuit: Islamic Terrorist or Christian Victim?}

At the point in the performance of The Passion at which Jesus is arrested, he is dressed in an orange jumpsuit, and, after the conviction, a black bag is placed over his head before he is escorted off the stage by two security guards in black uniforms. ${ }^{41}$ The orange jumpsuit and the black uniforms have been both part

39 Interview April 13, 2015 (1) conducted by Anita Zijdemans.

40 In all editions of The Passion so far, the men playing the Jesus character have had beards or, at the very least, a bit of stubble. Most editions have cast white men in the role of Jesus, and black men have only been cast for this role twice (singers Dwight Dissels and Edwin Jonker, both with Surinamese roots, in 2017 and 2019). The one man with Mediterranean looks to have his name suggested during the casting process for 2018, was rejected by one of the organising parties because he was a practising Muslim (see the second issue, elaborated below). The suggestion of having a female play the role of Jesus has been made twice, by the (female) narrator of the 2016 edition, Lenette van Dongen, and by the author of an op-ed in one of the Dutch newspapers, who encouraged the organisers to go for a less 'old-fashioned' edition of The Passion. See De Volkskrant, "Tijd voor vrouwelijke Jezus in The Passion", March 26, 2016, https://www.volkskrant.nl/nieuws-achtergrond/tijd-voor -vrouwelijke-jezus-in-the-passion bf87aodg/. Last accessed May 10, 2020. Up until the 2018 edition, this suggestion has not been taken up by the organisers.

41 Like Jesus, Barabbas too is presented to the public as a prisoner wearing an orange jumpsuit. We focus here on the presentation of Jesus because he plays a crucial role in Christianity and may, in this case, even be considered to symbolize Christianity or Christians 
of this scene and a subject of discussion, mostly on Twitter and Facebook, since the first edition of The Passion in Gouda in 2011. Yet, in 2015, the scene prompted strong(er) reactions from many viewers via social media. After previous editions of The Passion, the potential association with 'Guantanamo Bay' (the American base associated with images of Al-Qaeda and Taliban detainees wearing orange jumpsuits) had been mentioned in connection to the orange costumes (with Jesus resembling a religious terrorist to be put away), but in 2015 many people on social media saw a strong connection between these orange jumpsuits and videos that had been circulating depicting the execution of prisoners, and particularly Christian dissidents, by the Islamic State (ISIS) in Iraq and Syria.

The depiction of Jesus in an orange jumpsuit was seen by viewers as a symbol of religious persecution, particularly the persecution of Christians, and the Easter story was interpreted by some as a message about the importance of the right to freedom of religion or belief, although this was not the explicit intention of the organisers of the event. This interpretation is clearly articulated in

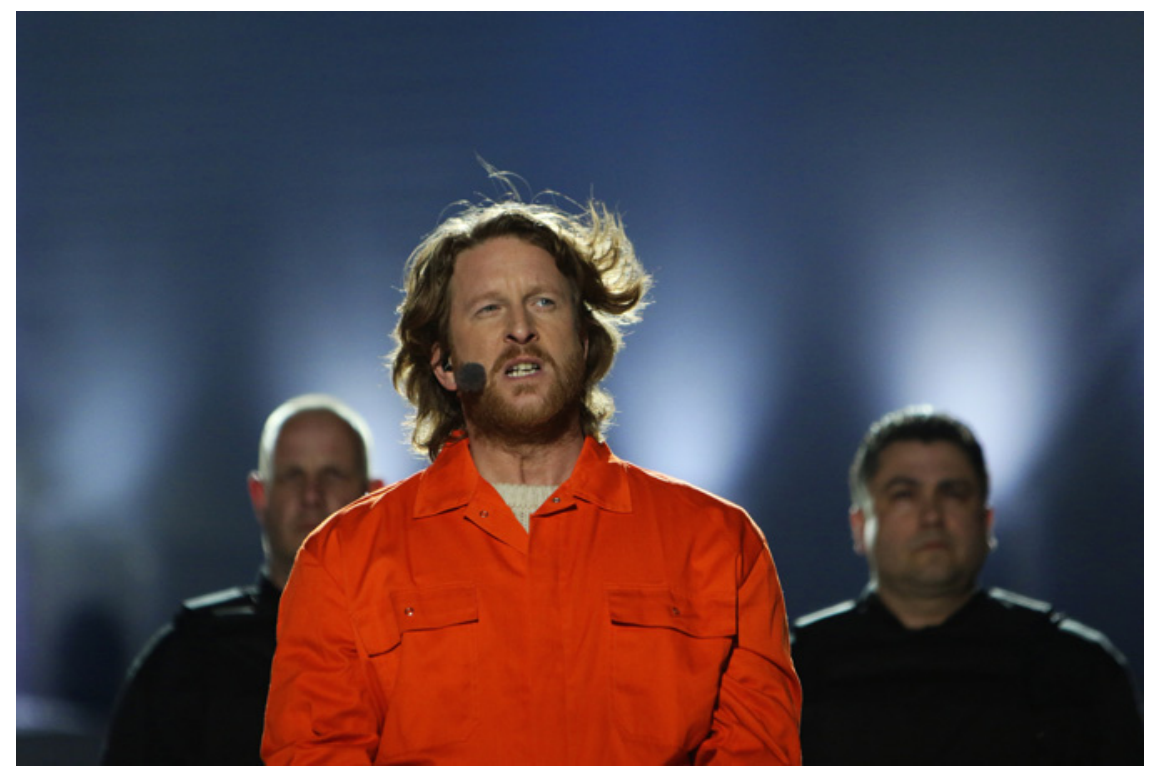

FIGURE 11

The Jesus character in an orange coverall with two soldiers after his conviction in The Passion, Enschede, 2015

PHOTO: ARIANNE RAMAKER. CEO

as a whole, as well as because of the way in which his wearing an orange coverall caused upheaval on social media. 


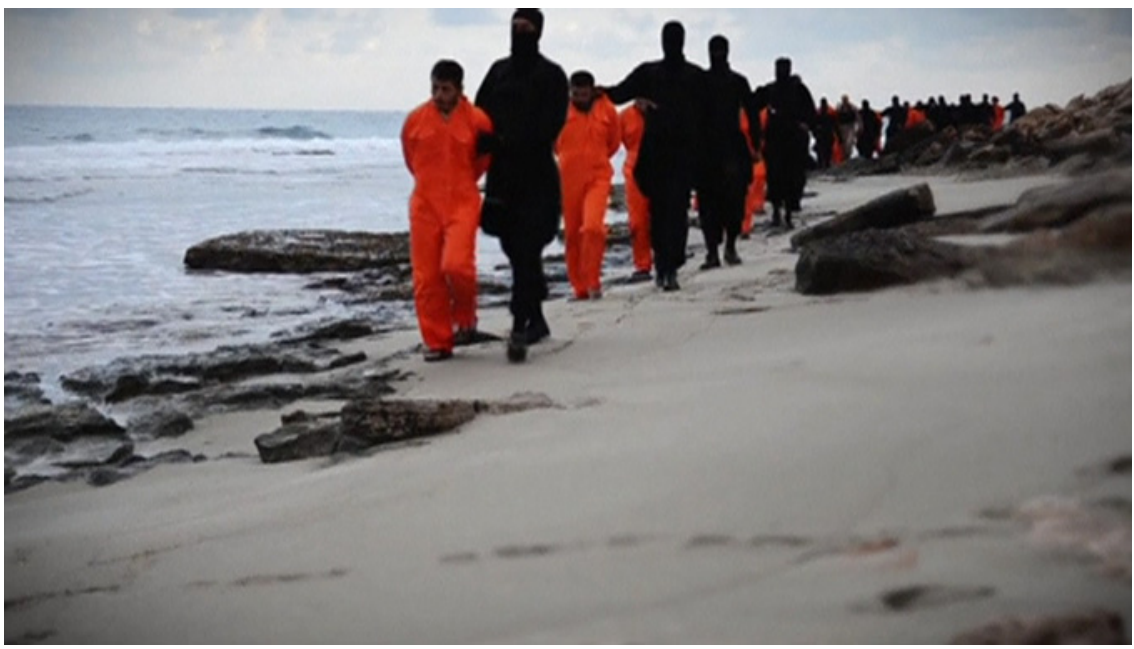

FIGURE 12 Christian victims of ISIS led to their execution on a Libyan beach SCREENSHOT FROM A YOUTUBE-VIDEO POSTED BY ISIS ON FEBRUARY 16, 2015

a strand of discussion concerning the terrorist attacks that took place in Kenya on the day of the 2015 Passion, in which Al-Shabab militants killed 147 Christians. ${ }^{42}$ The official Twitter account of The Passion linked the orange jumpsuit to religious persecution, thus connecting it with the situation in Kenya: "The Orange jumpsuit represents religious persecution. Just like in the Easter story, people today are also being persecuted and killed because of their belief". ${ }^{33} \mathrm{In}$ this case, the persecutors were (radical) Muslims, and the victims were Christians. Responses to this tweet were varied. Whilst some people accepted the explanation that was given, others considered it to be a far-fetched excuse from the organisers of The Passion for a mistaken decision to portray Jesus this way. Some people simply contradicted the statement, saying that the orange jumpsuits were a reference to Guantanamo Bay or IsIs. Several people on Twitter pointed out that these orange jumpsuits had been used in The Passion prior to their use by Is. In fact, the orange jumpsuits had already been used in the Manchester Passion, before the event took place in the Netherlands for the

42 See ввс, "Kenya Attack: 147 Dead in Garissa University Assault", April 3, 2015. https:// www.bbc.com/news/world-africa-32169080. Last accessed May 10, 2020.

43 For this tweet, including the responses to it, see The Passion (@thepassion), Twitter, April 2, 2015, https://twitter.com/thepassion/status/583724457321181184, accessed October 31, 2019 . 
first time in $2011 .{ }^{44}$ Still, the negative association and moral criticism caused people to tweet comments such as: "An orange jumpsuit... I fear that not a crucifixion, but a beheading will follow". ${ }^{5}$ And: "Okay. Respect current wounds and adjust the play. Swastika=abomination, Orange Jumpsuit=abomination. Who knows [what happens] in 2016 ?"46 Producer Jacco Doornbos, on the day after the 2015 performance, explained the controversy surrounding the orange jumpsuits, arguing that the passion story was controversial in nature, just as it had been two thousand years ago. ${ }^{47} \mathrm{He}$ explained that when The Passion was first performed in the Netherlands in 2011, the orange jumpsuits were a reference to Guantanamo Bay. Now, Doornbos said, they are linked to awful videos from Is. ${ }^{48}$ Remarkably, he did not link the orange colour to religious persecution in the same way as the official Twitter account mentioned above. The organisers seem not to have collaborated with one another in order to put together a common statement on this topic.

This example led us as researchers to focus in on the (different?) attitudes of the organisers towards Islamic religion a little further. On 22 March 2016, two days before the performance of The Passion, the Islamic State shocked the general public (at least in European countries) with a series of terrorist attacks in Brussels, the capital both of Belgium and of Europe, situated about an hour's drive from the Dutch border. ${ }^{49}$ In the Netherlands, people immediately started

44 The Manchester Passion is the event that inspired the Dutch producer of The Passion to stage the passion narrative in a similar way in the Netherlands. The Manchester Passion took place on Good Friday, 14 April 2006, and was aired live оn ввс Three. For more information, see, e.g., "The Manchester Passion", ввс, April 13, 2006, http://www.bbc.co.uk/manchester/content/articles/2006/04/10/140406 _manchester_passion_event_feature.shtml. Last accessed October 31, 2019.

45 For this tweet, see Niels Roelen (@nielsroelen), Twitter, April 2, 2015, https://twitter.com/ nielsroelen/status/583716212431028225. Last accessed October 31, 2019.

46 For this tweet, see Marion (@maestraroos), Twitter, April 2, 2015, https://twitter.com/ maestraroos/status/583731689928728576. Last accessed October 31, 2019.

47 Doornbos gave this explanation at prime time on RTL Late Night, a popular talk show on RTL4, one of the largest commercial broadcasting channels in the Netherlands. Only a fragment of the TV-broadcast is available online. See RTL Late Night, "Jeroen herhaalt huzarenstukje The Passion" https://www.rtlboulevard.nl/entertainment/artikel/1253731/ video-jeroen-herhaalt-huzarenstukje-passion. Last accessed May 10, 2020.

48 It is remarkable that Doornbos used the word "vreselijk" (awful) to refer to IsIs but did not use it when he talked about Guantanamo Bay.

49 The attack took place in Brussels on the morning of 22 March 2016, The Passion was performed on 24 March 2016. Is Is claimed responsibility for these attacks later on the same day. See The New York Times, "Strikes Claimed by IsIs Shut Brussels and Shake European Security", March 22, 2016, https://www.nytimes.com/2016/o3/23/world/europe/brussels -airport-explosions.html. Last accessed May 10, 2020. Prior to these attacks, Paris had 
wondering whether or not it would be safe enough to attend The Passion in the square belonging to the Dutch city of Amersfoort on the 24th. In a radio interview, a reporter asked producer Doornbos: "Have you considered cancelling the event?" He replied: "No, not for a moment; I believe that, particularly in these days, we must tell this narrative as [it is] a story of hope, a story of love and a story that connects all of us, more than that it divides".50 Now, although Islam is by no means to be equated with militant extremism, militant action and Islamic faith were, in the case of these attacks, linked together. Although the producer did not mention Islamic religion but, rather, talked about the terrorist attacks, an event based on the Christian passion narrative was presented as the complete opposite of the attacks which resulted from the radical Islamic ideology of Is (hope; love; qualities of connection vs. the sowing of division). His response was in line with the general positive framing of the passion narrative as 'a story of hope and love, ${ }^{51}$ and with the organisers' original aim to present the Christian passion narrative in the public sphere as a narrative relevant to everyone. ${ }^{52}$ However, in this particular situation, this presentation

been hit twice in 2015 (the Charli Hebdo shooting on 7 January and the Bataclan attacks on 13 November). After the suicide bombings in Brussels, more terrorist attacks in a number of other European cities followed later in the year (Nice, 14 July; several German cities in July and December 2016). Is Is claimed responsibility for most of these attacks.

Quotation taken from live radio interview with Doornbos on 24 March 2016, "The Passion 2016 in audio en video", NPO Radio 2, March 24, 2016, https://www.nporadio2.nl/nieuws/ 11261/the-passion-2016-in-audio-en-video. Last accessed May 10, 2020. The translation is mine.

$5^{1}$ In the introduction to each edition of The Passion the narrators mentioned a number of different qualities which the passion narrative embodies; love (and hope) were mentioned in the introduction to every edition.

$5^{2}$ His response was also not exceptional in the sense that there were many people who publicly expressed a strong disapproval of the attack. The Dutch Prime Minister, for example, in his official statement said that "the horrific, cowardly attacks in Brussels this morning are terrible and shocking. This is premeditated murder". See "Statement by Prime Minister Mark Rutte on the attacks in Brussels", Government of the Netherlands, March 22, 2016, https://www.government.nl/latest/news/2016/o3/22/statement-by-prime-minister -mark-rutte-on-the-attacks-in-brussels. Last accessed May 10, 2020. Later, in an interview in 2019, the producer referred to the polarisation of society and the necessity for different groups to become familiar with each other's narratives. With respect to The Passion, he seemed to have the connection between Christians and non-religious people particularly in mind, more than between Christians and people adhering to other religions: "Particularly in times of polarisation, it is important for people to be familiar with each other's narratives. In that sense, The Passion has a connecting quality, because non-religious people are watching and playing a role in the event too". "The Passion' als verbinder", Spreekbuis, April 16, 2019, https://www.spreekbuis.nl/the-passion-als-verbinder/. Last accessed May 10, 2020. 
of The Passion in the context of terrorist attacks may, perhaps inadvertently, have contributed to creating a positive frame for Christianity whilst creating a negative frame for Islam.

A year later, in an interview as part of our fieldwork, we discovered that in the preparations for the 2018 edition another organising party had strongly objected to casting a Moroccan-Dutch actor who is a practising Muslim in the role of Jesus. ${ }^{53}$ During the casting process, this actor had been offered the role of the narrator. He declined, but added that he would be eager to play the role of Jesus instead. In the ensuing discussion among the organisers, one of the Christian broadcasting companies strongly opposed having a Muslim play the character of Jesus in a Christian ritual. Although this broadcaster had consented to the presence of Muslims on camera more-generally (e.g. during the procession ${ }^{54}$ ), having the character of Jesus played by a Muslim was a bridge too far: this was an issue too sensitive for some parts of the broadcasting company's Christian constituency. Other organising bodies countered the objection with the reproach that year after year this company had agreed to the casting of atheists in the role of Jesus, despite now refusing to cast a (liberal) Muslim for this role. ${ }^{55}$ Eventually, the other organisers gave in, and a non-religious singer was allocated the role of Jesus. ${ }^{56}$

These examples reflect a level of ambiguity surrounding the meaning of religious images in contemporary Dutch society, as well as ambiguous attitudes towards Christian religion, Islamic religion and secularity more-generally (the opening quote of this chapter resonates with this ambivalence). The orange jumpsuit, in an event based on a Christian narrative in a post 9/11 context, is a multifarious symbol, the use of which can lead to moral indignation since portraying Jesus in an orange jumpsuit is believed to be undesirable in times

53 Anon., interview by $\mathrm{MK}$, autumn 2017.

54 In 2015, one of the people who was part of the procession was interviewed and told the 'journalist' that he was a Muslim and that he enjoyed The Passion. See "The Passion 2015", video, at 23:0o.

55 After they had given in, those who had been in favour of this particular actor playing the role of Jesus used the refusal of the objecting broadcaster as leverage in the negotiation of other decisions. Fieldnotes and interviews show that from the first edition in 2011 onwards, conflicts between the different interests of the organising parties, politics and (sometimes hard) bargaining have been part of the preparation process of The Passion.

$5^{6}$ In 2018, Tommy Christiaan eventually played the role of Jesus. In an interview he said: "I am not religious. But because I was in a school based on Steiner education [Vrije School, $\mathrm{MK}]$, I was raised with the Biblical stories which always contain a lot of nice themes". "Interview Tommie Christiaan als Jezus in The Passion 2018", Zin in Vandaag (кRO), March 19, 2018, https://www.televizier.nl/amusement/tommie-christiaan-a-the-passion-is-voor -iedereena. Last accessed August 19, 2019. 
of societal turmoil. Its use also leads to confusion, as it evokes references to a variety of different things, including alleged Islamic criminals, Christian victims of terrorism, and religious persecution. Presenting the Christian narrative as a story of hope and love that connects and unites rather than divides people can, in the context of terrorist attacks by Islamic State, send a message that is at odds with the inclusive aim of the event, since Muslims who dissent from the attacks do not necessarily sympathise with the Christian passion narrative, and the same holds for the inclusion and exclusion of Muslims from the event depending on their roles.

All this demonstrates that The Passion, both explicitly and implicitly, has become tied to current public debates regarding religious terrorism and violence - issues looming large both in Dutch society and in Europe more generally. A Christian play, staged in the public sphere, is not a harmless ritual, but an event that makes it clear to Dutch society that 'religion' is not as separate from identity and politics as it was previously assumed to be. The rising visibility of Islamic religion in particular, as well as radical Islamic groups whose oppression and use of violence have led to an influx of refugees into Europe, signals major change within European societies. The danger of portraying of prisoners in orange suits in The Passion is that Islam could easily come to be considered a 'bad religion', in contrast to Christianity, which is allocated the role of 'good religion'. The Passion serves to confuse ordinary everyday categories: in a secular society where religion is often considered to remain a private issue, through the performance of The Passion, the public sphere becomes a 'sacred' space ${ }^{57}$ that reflects a number of ambivalences relating to religion and secularity. In and around the performance of The Passion, Dutch society reflects and comments on itself and is enabled to realise just how far it has fallen short of its own 'ideal secular standard', in the face of (the fear of) Islamisation and the European refugee crisis that is becoming a part of daily life.

\section{The Morality of the Actors}

The third controversial issue to be considered regards the moral character of the actors. This is most clearly shown in the discussion around Dave Roelvink's portrayal of Barabbas in the 2015 edition of The Passion. Roelvink, the then twenty-year-old son of a Dutch celebrity folk singer, became famous in the Netherlands in 2014 when a sex video appeared on YouTube of an orgy in which he participated. A woman who appeared in the video brought a lawsuit

57 Sacred, according to Turner's understanding as distinct from the profane, secular, or mundane. 
against him and also accused him of theft. ${ }^{58}$ On social media, some users, especially young women, expressed that they found him very attractive. This also became clear on the square in Enschede, where we observed a small group of mothers with their young daughters: the moment Roelvink appeared on stage, the mothers lifted their daughters up so they could see him, resulting in jubilation from the daughters.

Whilst some celebrated Roelvink's appearance, some commentary focused instead on Dave's immoral background, which, in the eyes of many people, made him unsuited to participate in such an event. A poll on the website of the largest national newspaper in the Netherlands, De Telegraaf, asked people whether they thought it was acceptable that someone of disrepute (Roelvink had not yet been convicted) would participate in The Passion. Remarkably, $72 \%$ of the people who responded to the poll were against the participation of Roelvink. ${ }^{59}$ Precisely because of his background, his participation was also the focus of major discussions on social media. The character that Roelvink played was that of Barabbas, the criminal who gets released instead of Jesus. Because of his background, Roelvink was in fact typecast in this role, a point emphasised by the producer of The Passion, Doornbos. In an episode of $R T L$ Late Night that aired on the day after The Passion Doornbos explained that each year someone who has been recently discredited in the media is chosen to portray Barabbas. ${ }^{60}$ For this reason, Roelvink, in the opinion of the organisers, made an excellent candidate. ${ }^{61}$

Similar dynamics emerged in discussions about the decision to let de Groot portray Jesus. De Groot was brought up in an atheist family and had a history that included drug abuse. Before The Passion was staged, some of the

$5^{8} N U$, "Dave Roelvink vervolgd voor diefstal en heling", March 25, 2015. http://www.nu.nl/ achterklap/4018720/dave-roelvink-vervolgd-diefstal-en-heling.html. Last accessed May 10, 2020.

59 See De Telegraaf. "EO de mist in met Dave Roelvink", April 1, 2015. https://www.telegraaf .nl/entertainment/837013/eo-de-mist-in-met-dave-roelvink. Last accessed May 10, 2020. See also Mirella Klomp and Marten van der Meulen, "The Passion as ludic practice - understanding public ritual performances in late modern society: a case study from the Netherlands", Journal of Contemporary Religion 32, no. 3 (2017), 387-401. DOI: $10.1080 / 13537903.2017 .1362879$.

6o See "Jeroen herhaalt huzarenstukje", RTL Late Night.

61 The producer could have chosen to bring up a theological reason inherently related to the Christian narrative for this typecasting, stating that status reversal is the core message of the gospel (since God exalts the humble, fill the hungry with good things, etc.), but that would contradict one of the most fundamental qualities of The Passion: its openness (cf. Chapter 1). Too much theological content would hinder people's ability to ascribe their own meaning to the event. 
production team doubted whether he was suitable to play Jesus due to his background. According to the chief editors of both EO and RKK, a complicating factor in this situation was that the media focused very much on his past, instead of focusing on his upcoming performance. ${ }^{62}$ The media emphasised the conflict between de Groot's unreligious past and his participation in a religious event. Through our interviews with the organisers, it became clear that this was especially problematic for the evangelical broadcasting company EO and their supporters, since the debate did not just take place inside of different Christian groups, but was conducted publicly, primarily in the media.

The debates surrounding the actors playing Jesus and Barabbas and their characterisations in The Passion involves the public thematisation of a moral topic, i.e., whether someone of disrepute can have positive public recognition on a TV show. This is directly related to the status reversal mentioned by Turner: individuals whom one would not expect to be asked to play a role in this event, because of their way of life or their ethical behaviour, get two of the most important roles. However, that is not the whole story: just as important as this ritual reversal are the ways in which a society is able to comment on and critique itself (e.g. through social media). ${ }^{63}$ Interestingly, these comments show that, in the eyes of the public, the atheism and drug abuse of de Groot seemed to be less of a barrier to playing a role in The Passion than the sexual infractions of Roelvink. This discussion does not occur just in one location, but across a variety of different, converging media. This shows the continuing ability for religion to engender and channel public debate. ${ }^{64}$

All things considered, in dealing with the different uncertainties around national identity explored in The Passion, the striking duet of Pontius Pilate and Jesus after his arrest, which is the only song to have been a recurring element of The Passion since the very first edition, may function as an appeal to stay away from black-and-white views on (religious) matters and to refrain from radical (moral) judgements. The text of the chorus can be interpreted as underlining the complexity of current societal debates and the varying ambivalence of societal issues, thereby calling on both individuals and collectives (perhaps even upon the organisers themselves) to act in a particular way: "Don't think white, don't think black, but think in the colour of your heart".65

\footnotetext{
62 Interviews February 6, 2015 and April 13, 2015 (2) conducted by Anita Zijdemans.

63 See Turner, "Frame, Flow and Reflection", 467.

64 For further discussion, cf. Chapter 5.

65 "Denk niet zwart, denk niet wit, denk niet zwart-wit, maar in de kleur van je hart". "Zwartwit”. Frank Boeijen Groep. https://www.songteksten.nl/songteksten/14124/frank-boeijen/ zwart-wit.htm. Last accessed May 10, 2020.
} 


\section{Conclusion}

Our examination of The Passion as a public meta-social ritual has brought to light a number of different themes regarding Dutch society. In a polarising society that was thought to be secular, the portrayal both of the Jesus character, and of Christianity itself, seems to suggest that Christianity and atheism are tied to Dutch culture more than Islam is. At the same time, Christian religion and Islamic religion both carry with them a degree of ambivalence. The status reversal that can occur in public ritual has the ability to evoke moral indignation as well as a discussion of ethical conduct in which norms and values may indeed be re-shaped and calibrated. We conclude that The Passion as a public reflexive practice brings to light large-scale ambivalences regarding religion and secularity. Returning to our research question regarding the ways in which a public religious event is able to engender public reflexivity in relation to contemporary religious and moral debates we thus conclude that The Passion mirrors contemporary social issues, both through its narrative representations and depiction of different characters and in the discussions which it evokes surrounding these themes. However, it does not simply reflect contemporary issues: through its mode of performance the play also shapes the reflection, steering it in different, perhaps even divergent directions. With the use of digital media this public reflexivity also acquires a virtual dimension, as it is performed across different media which engender both interactive participation by the public over the course of the ritual and comments by the public on the ritual. These reflexive practices add to current discourses regarding (in this case) religion and secularity, and morality. This, in turn gives us reason to believe that the religious and moral debates that are engendered and channelled by The Passion may, in the long run, influence the secular selfunderstanding of the Dutch.

Three additional questions require our consideration: (1) What does The Passion tell us about the (post-)secular character of Dutch society? (2) Could a non-Christian, secular, or other-religious event have a similar role as metasocial ritual when it comes to public reflexivity? and (3) How dangerous is the potential dichotomy between good and bad religion that may have been created?

Connecting debates regarding post-secularism together with Turner's theory, it is possible to expect some kind of societal response to meta-social rituals such as The Passion, especially in times of contestation. ${ }^{66}$ The Passion

66 This does not necessarily mean that the whole of society is in accord with what is being reflected on or agrees on the outcomes of this reflection. According to Lynch, public 
shapes and evokes debates regarding important public topics. Rather than understanding this as a reversal of a trend towards secularisation, we understand it as an affirmation of the post-secular condition and the complexity and ambivalences surrounding religion and secularity in contemporary society. Without retracting our critical comments on post-secular theory (see above), we think that The Passion points to the essentially contested nature of what being 'religious' or 'secular' means in the current moment. The event derives its salience and popularity from addressing and thematising this contestation.

In elaborating this idea, the question is raised of whether a non-Christian event, either from another religion or of a secular nature, could have the same function in relation to public reflexivity. Of course, this is a topic that requires further research, but we offer a provisional argument along two diverging lines. On the one hand, it is important not to underrate the importance of the Christian heritage element in The Passion. Europeans are subconsciously shaped by their Christian past, even if they assume themselves to be secular. ${ }^{67}$ The story of the suffering Christ is so well known and taken for granted that it can form a common tableau through which to thematise and discuss important public topics in a way that a story of the life of Mohammed, to give but one example, cannot, particularly in times of religious polarisation in which some politicians use religion in both positive and negative ways to advance their own political ideologies. The narrative of the Passion and its role in European life offer the possibility for public reflexivity, so the Christian character is central. However, on the other hand, we should also be aware that there are a variety of other sacred forms, many without religious or Christian content, which offer the opportunity for society to think about itself. Non-religious events can also be experienced as sacred events and can trigger a similar type of public reflexivity as The Passion. ${ }^{68}$ So, to sum up, while the Christian character of The Passion is an important feature in our understanding of its public-reflexive role, its Christian character is by no means a necessary condition for this role.

The Passion is not a neutral event. By portraying the central characters in a particular way, the producers influence not only how the public will think

media represent "the sacred in ways that generate fragmented, overlapping and often transient forms of collective identification that may perpetuate social conflicts as much as integration". We agree with his criticism, but want to stress the collective character of the event. See Lynch, The Sacred, 88.

67 See, e.g., Jan Assmann, Religion and Cultural Memory: Ten Studies (Stanford: Stanford University Press, 2006).

68 We here pick up Lynch's distinction between the sacred and the religious, see also Chapter 4 . 
about the story but also how they will think about the moral and religious topics which are explored in the show. In this regard, we found the portrayal of Jesus and Barabbas as prisoners in orange suits particularly unfavourable, as this has the potential to reinforce a dichotomy between 'good religion' and 'bad religion'. In recent years, the orange suits have called radical Islam to mind, as something which is not part of - and, in the eyes of many, should not become part of - contemporary Dutch national identity. Radical Islam is not considered to be harmless, but is seen as a threat to both European and Dutch society. The comments and criticism evoked by the orange suits lay bare a fear of and antipathy towards radical Islam, a fear of something which is 'not our religion' and which should be kept at a great distance from society.

In this respect, it is specifically the positive characterisation of Jesus Christ as someone possessing openness and integrity, on the one hand, and the negative feelings caused by associations with religious (Islamic) fundamentalism, on the other hand, that makes the portrayal dangerous, because it may contribute to portrayals of Islam and Christianity that depict Islam as intolerant and oppressive, and Christianity as an inspiration for secular values of equality, democracy, and human rights. ${ }^{69}$ The producer and the broadcasting companies have indicated that this good-bad portrayal was not their intention, and have repeatedly indicated that they try to be inclusive. Yet, by maintaining the orange suits in a latent anti-Islamic societal climate in which the events of The Passion are characterised as liberal, open and positive they may be jeopardising their own efforts to be inclusive.

We offer our interpretation of The Passion as a meta-social ritual which engenders public reflexivity as a contribution to academic understandings of modern religion and secularity. Future research should be sensitive to the variety of sacred forms - whether they are called 'religious' or 'secular' - that people use to portray themselves, understand themselves and act upon themselves, both individually and collectively. The multimedia character of The Passion also needs to be borne in mind, reflection around and participation in contemporary rituals does not simply happen in one place, in one square,

69 This can be found in rulings by the European Court of Human Rights, but also the anti-Islamic ideology of populist politicians, like Geert Wilders in the Netherlands. Beaman, "Battles over Symbols". On the Dahlab case, see Carolyn Evans, "The 'Islamic Scarf' in the European Court of Human Rights", Melbourne Journal of International Law 7, no. 1 (2006), 52, http://www.austlii.edu.au/au/journals/MelbJIL/2006/4.html. Last accessed September 26, 2016. On the Lautsi case, see European Court of Human Rights Grand Chamber. Case of Lautsi and Others v Italy Judgement. March 18, 2011. http://hudoc.echr.coe.int/eng?i=oo1-104040. Last accessed May 10, 2020. 
in one building, but across a range of media in an ongoing process of conversation. Finally, the role of the individual and the collective in this process is also important. The Passion is an event that is both highly individualised and collectively experienced. The paradoxes, ironies, ambivalences and reversals in and around contemporary religion should alert us to the fact that interesting developments are taking place in our societies with regard to religion, and these dynamics are likely to be with us for some time. Scholars would do well to keep their eyes and ears open for other liminal forms of public reflexivity. 


\section{Side Light: Reflections in a Mirror. A Meditative Exegesis}

In 1974, the Dutch Pandora Foundation (Stichting Pandora), which aims to improve the position of people with psychological and psychiatric problems in society, and which works actively against prejudices, published a poster with a slogan that translates as "Have you ever met a normal person? So... did you like it?" Graphic designer Frans van der Aa had the Dutch text, a quote from the famous zoth century writer Simon Carmiggelt, printed on reflective paper. The poster was widespread in the Netherlands, decorated many walls, doors and windows, and the slogan became famous, almost to the level of reaching proverb status. Even today, one can occasionally still run into it (Stichting Pandora to this day has sold the poster in their web shop); I recently did, in the bathroom of a café in the city of Amsterdam.

The effect of the mirror paper is that spectators see their own faces when reading the text and, as a result, are challenged to wonder whether they themselves have really got both paddles in the water. What is 'normal'? What is the difference between 'them' and 'us'? What do these people say about me? The poster reflects both the complexity and the effectiveness of a mirror in the public sphere: it is empathically intended to make people wonder, raise questions, and reflect upon their understandings, and it implicitly invites them to reconsider or even change their ideas about and behaviour towards other people. It doesn't just aim to present people with their mirror image, this is not the final goal: more than this, it expresses a desire to move beyond the categories of normal and abnormal. The mirror symbolises an anacrusis to a further and deeper yearning.

A mirror also pops up in one of the writings of Paul the Apostle, in his first letter to the Corinthians. Towards the end of Chapter 13, which is often understood as an ode to love, Paul contrasts our current seeing in a mirror with a future seeing face to face: "For now we see in a mirror, dimly, but then we will see face to face. Now I know only in part; then I will know fully, even as I have been fully known". (1 Cor. 13:12). The Greek word here translated with 'dimly' is ainigma: a riddle or puzzling saying. In the Septuagint, this word is also used in describing a divine meeting, namely when God is said to speak to Moses, "face to face - clearly, not in riddles" (Numeri 12:8). By using this word in his letter, Paul stresses "the present, imperfect and partial character of man's 


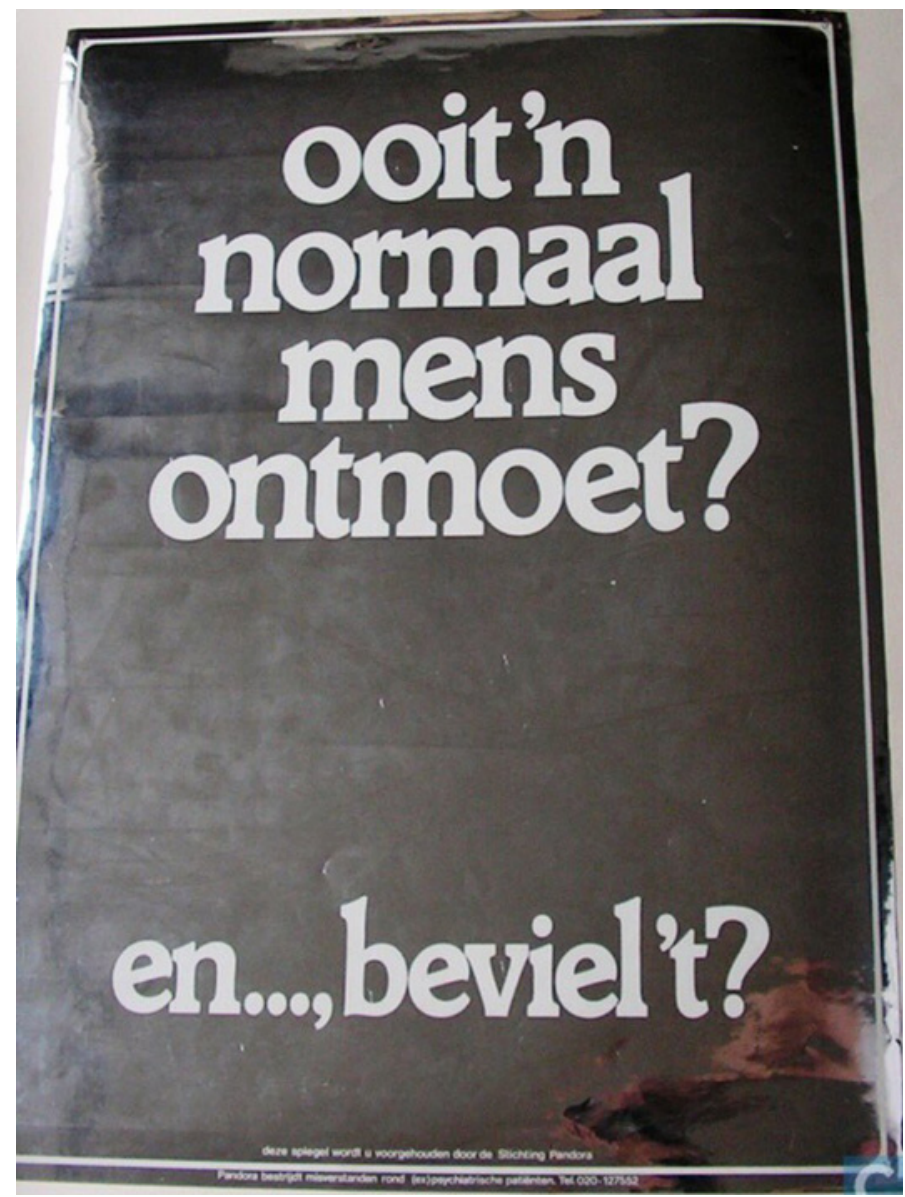

FIGURE 13 Poster for the Pandora Foundation

knowledge or vision of God". The point that he seems to be making here is not concerned so much with exactly what it is that we see in the mirror, but rather

1 Harm Hollander, "Seeing God 'in a riddle' or 'face to face'. An Analysis of 1 Corinthians 13.12", Journal for the Study of the New Testament 32, no. 4 (2010), 395-403, here 397. Dor: 10.1177/ 0142064X10365115. Hollander corrects the older idea that the mirror refers to an obscure image: "Most modern interpreters of 1 Cor. 13 correctly assume that the mirror imagery does not allude to the quality of seeing, in the sense that in Paul's view the image of God that we have is obscure or distorted. It rather refers to the indirect nature of looking into a mirror, in the sense that the apostle wanted to underline that man's vision and knowledge of God and the divine world is indirect: we see no more than the image of God". Hollander, "Seeing God", 397 . 
with the way that we see: indirect, mediated, incomplete. ${ }^{2}$ In a mirror we only see a reflection, an image of the thing, and not the thing itself. This contrasts with a direct way of seeing, with a knowing and understanding that is clear and complete. Biblical scholars have suggested that Paul intends to outline a difference between the type of knowing that is related to the gifts of the Spirit and a type of knowing that is eschatological and thus complete. The latter is God's own way of knowing. ${ }^{3}$

Like posters, public events can also function as a mirror. In The Passion, one can see, as in a mirror, a reflection of society's self-understanding. Paul's letter to the Corinthians suggests that one could also see, in The Passion, a reflection of how God understands society, of how God fully knows and understands us a reflection that is (still) indirect, imperfect, partial, and incomplete, but which is nevertheless real. From Moses, Paul derives the hope, desire and expectation that complete knowledge will one day also be granted to us - that we will know directly, fully, completely, and share in God's way of knowing.

This hope, desire and expectation may be an incentive to take public events like The Passion seriously for their potential to mirror fragments of the divine. Could this then be true: that the status reversal of a young man of disrepute who was typecast for the role of Barabbas is a fragmented example of God flipping the order of our reality, because God fully knows us? Could uncertainties and polarisations regarding our national identity as reflected in an event like this also reflect a deeper desire to share in a more-complete knowledge that moves beyond our incomplete categories of right or wrong, good or bad? Could it reflect a craving, a further yearning after divine knowledge? To understand ourselves like we are fully understood?

21 Corinthians 13:9 has already mentioned this partial and ephemeral knowing, which may be understood both in a quantitative (fragmented) as well as a qualitative (fuzzy) sense. Cf. Joseph Fitzmeyer sJ, First Corinthians. A New Translation with Introduction and Commentary, The Anchor Yale Bible (New Haven: Yale University Press, 20o8), 497-498.

3 See e.g. Gordon Fee, The First Epistle to the Corinthians, The New International Commentary on the New Testament (revised edition) (Grand Rapids: Eerdmans 2014). 


\section{Staging the Resurrection: A Public Theological Practice}

When in the 2013 edition of The Passion, in contrast to previous editions, the resurrected Jesus appeared not on top of a tower, but beside a pool of water on a level with the audience, his apparition drew my attention to the possible theological implications of the staged ritual. ${ }^{1}$ It made me wonder whether, or how, the producers of the event were practising theology. Practical theology has been identified as, among other things, something which takes place amid the reality of daily life. As Bonnie Miller-McLemore has observed, "it develops in the midst of ordinary life circumstances", amongst the constitutive practices that shape faith among believers in home and society. ${ }^{2}$ But practices of theology can take place irrespective of whether or not faith is actively or purposefully embodied in these practices. As this chapter will show, producing an event that stages a crucial element of Christian tradition in the public sphere is not necessarily a public practice of faith, but it is a form of embodied practical theology. In what follows, I will excavate the public practical theology of the resurrection as constructed by the organisers of The Passion.

Public theology is generally understood to be a reflective, or even reflexive, practice which is undertaken by (academic) theologians, although there are exceptions. ${ }^{3}$ South African theologian Andries van Aarde, for example, in

1 This chapter is a thoroughly revised and updated version of an article that was published earlier as Mirella Klomp, "Staging the Resurrection: The Public Theology of Dutch Production and Broadcasting Companies". International Journal of Public Theology 9/4 (2015), 446-464.

2 Miller-McLemore, The Wiley-Blackwell Companion, 7.

3 Cf. for example the 33 places where 'practical theology' is mentioned in a practical theological handbook such as Miller-McLemore, The Wiley-Blackwell Companion. Here, the term is mostly used to refer to a practice whereby practical theologians link public theology to the communities around them, e.g. by contributing to public debates. Practical theologian Elaine Graham's Between a Rock and a Hard Place is worth mentioning here. In her book she proposes a Christian apologetics of presence in public life. Although I also understand my task as practical theologian as 'doing theology in the public sphere' (cf. Chapter 8), at the same time, I take public theology to be something that can be practised by different actors (cf. 'A multi-actor practice', below). Practical theology is performed not only theologians, but also by others who practice theology (sometimes unintentionally) in the public sphere. 


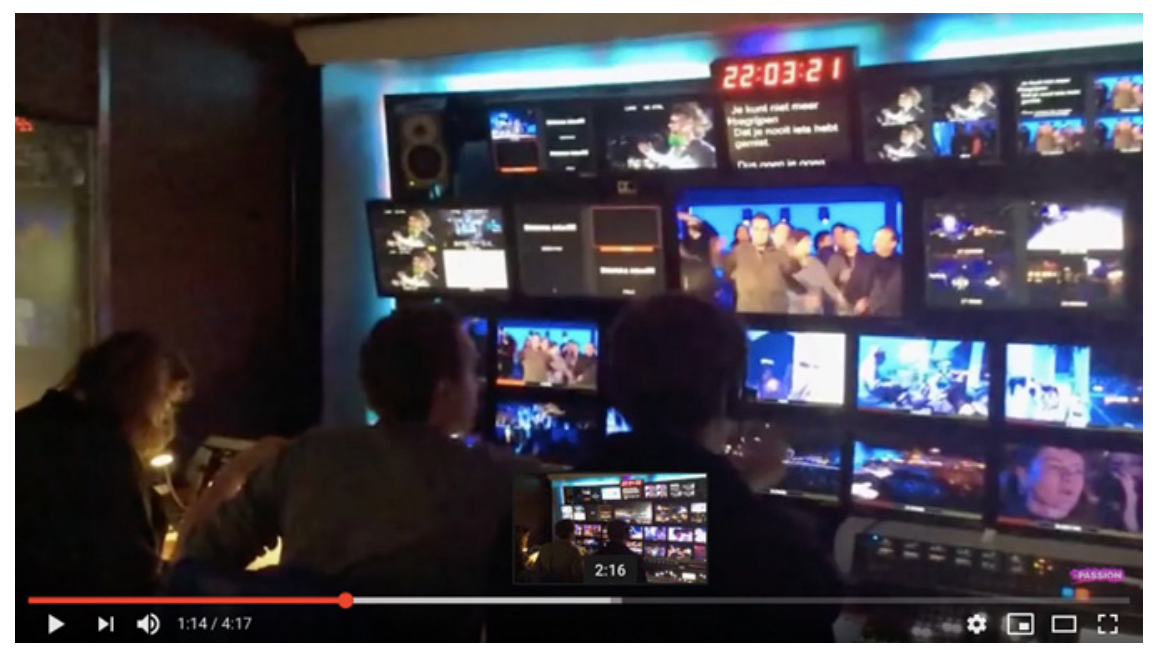

FIGURE 14 Television director David Grifhorst in the mobile production unit in 2015 A screenshot from the Youtube-video in which he is energetically directing the final scene that staged the resurrection (see the resurrected Jesus left and right of the clock in the upper row of screens). "Finale van The Passion 2015 vanuit de regiewagen", The Passion, streamed on April 4, 2015, YouTube-video, 4:17, https://www.youtube.com/watch?v=kkGfcFB8r-8. Last accessed May 10, 2020.

2008 wrote that in his opinion "'public theology' is not about theologians or pastors 'doing theology' in the public square. Public theology is the activity of the film directors, artists, novelists, poets, and philosophers". ${ }^{4}$ Building upon this viewpoint, I claim that public events such as The Passion constitute practices in which public theology and practical theology intersect at a 'grassroots level'.

In the following sections, I will show how the making of an event like The Passion is a way of performing public practical theology. Moreover, I will demonstrate how TV producers did more than simply present one of the most fundamental elements of Christian tradition. Rather, without being very aware of the ins and outs of their theologising, they publicly staged a theology of the resurrection of Jesus Christ. This is both a relevant and an exciting source of practical theological knowledge.

4 Andries van Aarde, "What is 'theology' in 'public theology' and what is 'public' about 'public theology'?" HTs Teologiese Studies / Theological Studies 64, no. 3 (2008), 1213-1234. Dor: 10 $.4102 /$ hts.v64i3.81. 


\section{Staging the Resurrected Jesus}

The resurrection, which, as many musical passion performances and compositions have demonstrated, is not, strictly speaking, part of the actual passion narrative, has been staged at the conclusion to all performances of The Passion. Towards the end of the story, after a somewhat detailed description from Pontius Pilate of what happens physically to a body as it is crucified in the first five editions, and after a song sung by Mary, the mother of Jesus in all editions, The Passion has always ended with a description from the narrators, followed by an apparition of Jesus depicting his resurrection. This resurrection was, however, introduced, suggested and staged differently in each of the editions. On the basis of a full examination of the final scenes, I will first describe the development of the different introductions to these scenes by the narrator over time, I will then discuss the staging of Jesus' apparition and the lyrics which he sang in three particular editions of The Passion in 2011, 2014 and 2019. ${ }^{5}$

\section{Introductions to the Finale}

The words by means of which the narrator brings the event to an apparent close after the death of Jesus are actually the introduction to the resurrection, since, after this 'ending', the final scene portrays the resurrected Jesus. These words and their tone have slightly evolved over the years. Anticipating the risk of a negative reception for The Passion in the first edition, since no one knew how the event would be received in secularised Dutch culture, the organizers chose to let the narrator mockingly suggest the resurrection of Jesus, rounding off the performance as follows:

It is finished, so to say. Some people said that he will rise from the dead. I also learned that Jesus himself said this a couple of times. [The narrator mockingly chuckles:] Don't you believe it? ... Well, we all know that this story does not have a happy ending. And this ending may not be a very good ending, but hey... we are, after all, in fucking Gouda! ... Thank

5 The resurrected Jesus appeared on top of a building adjacent to the city square where the organisers put up the stage in 2011 (the tower of St. Jan's Church, Gouda), 2012 (the Erasmus Bridge, Rotterdam), 2015 (the Alpha tower, Enschede), 2018 (AFC Ajax' Johan Cruyff ArenA, a temple for soccer fans, Amsterdam Bijlmer), 2019 (the Dordrecht Minster). In four editions, Jesus appeared close to the audience: at the Court Pond in The Hague in 2013, on the square in amidst the people in Groningen in 2014, in Amersfoort in 2016, and, together with Peter, in Leeuwarden in 2017. 
you for coming. From the Market Square in the city centre of Gouda on Maundy Thursday 2011: thank you, good night! 6

The following year, the positive reception of the first edition seems to have opened the way for a change in tone on the part of the narrator, becoming more neutral and less sceptical. At the end of the second edition, the narrator rounds off the event with a question:

It is finished, so to say. Maybe this is not really a nice ending. ... And what was the use? ... Some people said that he will rise from the dead. According to the Bible, Jesus himself said this a couple of times. Whether you believe he did, is up to you... And with this, our story seems to have come to an end. Or has it...?

In 2013, the text of the narration was similar, remaining neutral and open to a variety of possible interpretations, however, the second sentence had been altered into a tongue-in-cheek statement: "Maybe this is not really a Hollywood happy ending..."

As in the 2016 edition, the closing narration of the 2013 edition was turned into something both lengthier and bolder. ${ }^{7}$ The allusion to the apparition of Jesus slowly began to resemble a 'sermonette', or very small sermon. Sermonettes contain a number of elements: they name a particular situation (in this case the passion event in the city square), they tell a joke (or wordplay), and they offer a Biblical/scriptural equivalent for the situation, ${ }^{8}$ followed by a wrap-up or explanation which ties the illustration and scripture together in a meaningful way for the audience. ${ }^{9}$ Jokes have been a part of the narrator's script since the first edition. In 2011 this was a cynical joke on the city of Gouda, in 2013 a tongue in cheek statement referring to Hollywood (for the 2014 joke, see below). But, aside from jokes, since the 2016 edition the narrators have come to make clearer theological statements. The Biblical/scriptural/dogmatic component of the sermonettes in particular has taken a more emphatic stance: "Death and suffering do not have the final say. I repeat: death and suf-

6 English translations of Dutch spoken words and song lyrics in this chapter are mine.

7 I have no information on why the length and boldness of this particular part increased. Perhaps it was due to the general positive reception of The Passion, and perhaps the makers of this public event also felt urged to make a statement since the 2016 edition took place two days after the terrorist attacks in Brussels (see Chapter 6).

8 E.g. biblical verses, but I would broaden this further to include dense dogmatic articulations.

9 Cf. Dennis Burgess, The 6o Second War. A Collection of ADHD Sermonettes (Scotts Valley, CA: Amazon, 2015), introduction. 
fering do not have the final say" (in 2016), "Together, we decide what wins: love or hate. If only everybody would love the other like himself, this story would by no means be an end, but rather a new beginning. Because to fall [the narrator wags his finger and pauses] only becomes a problem when at the end of this story no one gets [back] on their feet" (in 2017). And in the 2019 edition:

This story began as a story of hope. How love would conquer fear. That no one would have to be alone any longer. And now? Now, a man who was misunderstood has been crucified and died. If Jesus, out of love, wanted to understand the deepest loneliness and misery of human beings, then he really went a long way down that road. With far-reaching consequences: dead, end of story. Or not?

The Bible describes how Jesus arose from the dead after three days, and that, by doing so, he confirmed his message that love indeed conquers all, even the pain of death. You either believe that this really happened, or you do not. Anyhow, Jesus was there, and when you really look carefully, you see that he is still here. Maybe in you, and perhaps today with me. The message of Jesus after so many centuries is clearly a message of power and of inspiration to care about each other, to reach out to the other, to make time for fellow human beings who all ill, who are strangers, who are held hostage, who differ from you. So that nobody is alone.

Thus, over the course of nine years, and probably due to the generally positive reception of The Passion, the concluding words that introduced the final scene evolved from a rather sceptical statement regarding the impossibility of somebody rising from the dead, to a hermeneutically more developed theological statement that linked Jesus to particular (groups or categories of) people in society. A message, moreover, with clear didactic aspects, teaching that Christ is still present today. I will continue discussing how the apparition of Jesus was staged in the editions of The Passion in 2011, 2014 and 2019.

\section{Gouda 2011}

In 2011, after the concluding words, the lights in the square were switched off. It was suggested that the show was over. The orchestra nevertheless continued to play dissonant sounds, and search lights started to cross the square. Then, suddenly, spotlights illuminated the tower of the monumental St Jan's Church right behind the stage, where the Jesus character appeared, singing. ${ }^{10}$

10 The Jesus character in all editions appeared without any wounds on his hands (or feet): after his death he did not visibly differ from before. 


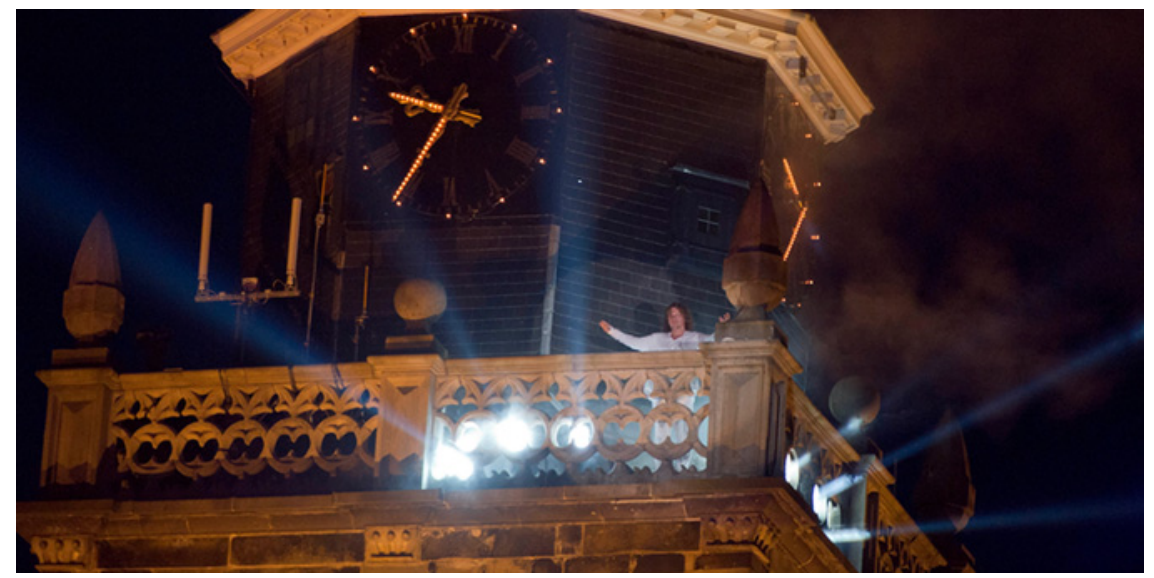

FIGURE 15 Singer Syb van der Ploeg as the resurrected Jesus on the tower of the St Jan's Church in Gouda Pното: (c) ANP

The first verse of the song, he sang a cappella, so that no attention was drawn to anyone other than him; later on, the orchestra accompanied his singing. People down on the square waved with the glow-in-the-dark devices which they have received when they entered the square; others sang along. The resurrected Jesus was staged up high, dressed in white clothes, standing with his arms wide open, ${ }^{11}$ and he sang the chorus of a very well-known Dutch pop song, the lyrics of which read:

Now give me your fear, I give you hope in return.

Now give me the night, I give you a new day in return.

As long as I do not lose you, I am sure I can find my way with you. ${ }^{12}$

The original lyrics have a number of different metaphorical layers. In the context of The Passion, the lyrics maintained these different layers, but some of their meaning was altered. For instance, in the verses, the main figure lures a second person into staying overnight ("This will never happen again if you decide to stay with me tonight: when you wake up, you will find yourself laughing

11 Interestingly, no painted wounds were visible on his hands: the narrator told the audience that Jesus was crucified, but in this presentation, after his death, he appeared unhurt.

12 The translation is mine. Full lyrics of "Geef mij je angst". André Hazes. http://www .songteksten.nl/songteksten/333o/andre-hazes/geef-mij-je-angst.htm. Last accessed May 10, 2020. It was a cover version of a song by André Hazes, one of the most famous Dutch folk singers in recent history. A previous cover version was sung by Guus Meeuwis at Hazes' own funeral that took place in a football stadium in 2004. 
again".) In the new context, in the mouth of Jesus, this song has the potential to become more of an offer of help for the spectators, or an invitation to follow him. The implied sexual meaning of the lyrics may, then, have moved to the background. Nevertheless, whether or not they have put their faith in God or allowed Jesus to walk beside them in life, whether or not they have believed in the resurrection of Christ, each person decided for themselves how to ascribe meaning to the song. Indeed, this ambiguity was at the heart of the presentation of the resurrection in this first edition of The Passion. The song can thus be understood as a call for trust: it was an invitation to confide all fear and all darkness and night to the first-person narrator who, in this case, took the form of the risen Lord who was staged on high. Those who did confide all this darkness were promised that they could receive hope and a new day in return. Given the organizers' aim of familiarising a wide audience with the narrative of Jesus, the physically and textually shaped theological message may have been that the risen Lord offers every individual a new start, a new day; he offers every person who decides to put his/her trust in the Lord the hope of resurrection. ${ }^{13}$

\section{Groningen 2014}

On the night before the performance of the fourth edition of The Passion, the producer and broadcasting companies made a last-minute change to the staging of the resurrection. They had planned to let Jesus appear on the tower of the Martini Church - one of the highlights of the city of Groningen, close to the Vismarkt, the big square where The Passion would be performed. But, a few days before the event, they decided that this church tower would be too predictable a location for the appearance. "After all", one of the press officers told me, "it is also a show, and it is important that it has some surprise to it as well. So, therefore we decided to stage the resurrection in amongst the people in the square. And then we thought, 'Oh! To have him appear amongst the people is actually quite meaningful!"'14 Clearly, after their directorial/production decision, a theological observation regarding the newly created reality followed. The element of surprise during the performance was heightened by the fact that the producers allowed the narrator to play with the audience and their expectations, and with the famous slogan that is used for in marketing for the city and province of Groningen. This Dutch slogan is a play on words

13 My reconstructions of the staged public theology in sections 3.1-3.4 are based not just on the quoted lyrics, but on the lyrics of the entire song.

Telephone interview by M K with Reinder van Dijk, May 8, 2014. 
that combines the geographical location of Groningen in the far north of the country with the claim that Groningen delivers quality in its events, products and services. In previous editions, the narrator had looked up to suggest that Jesus would appear somewhere in that direction. This year too, he said:

It is finished, to put it nicely. Whether or not you believe that this is the end of the story is up to you. The fact that we still tell this story here, 2000 years later, on the Vismarkt, leads me to the question of whether the death of Jesus may not be the end of the story... Some people said that he will rise from the dead. According to the Bible, Jesus himself said this a couple of times...

The slogan of this beautiful province is: 'Nothing tops Groningen...' Or...?

The narrator looked up in a searching manner as sound and lighting effects were deployed, and the cameras focused in on the tower of the Martini Church. Then the audience heard the singer who played the role of Jesus sing:

Look up, to the sun; do not search for answers;

let it go and hold on to me.

This road leads itself, it leads you to the future;

this cloud will quickly pass by. ${ }^{15}$

But Jesus did not appear on the tower. All of a sudden, the cameras moved rapidly downwards and showed the figure of Jesus standing among the audience in the city square. The artistic director decided to place his appearance among the audience, right there, in their midst. In this way, Jesus appeared in a place where no single TV viewer had expected him to appear, although the people at the back of the square naturally must have noticed that something was going on. The Jesus character touched, or suggested that he touched the people surrounding him. The audience in his immediate neighbourhood took pictures with their smartphones.

The call of the song to 'look up' contradicts the physical presence of the Jesus figure amidst the people. The lyrics can be interpreted as conveying a theological image of Jesus as a guide to follow, or maybe of Jesus as the Way, as the road that will lead to the future. This road, Jesus, then becomes the future,

15 The translation is mine. This final resurrection song, as in 2013, was a cover of a song by the duo Nick and Simon. The verses were left out; only the chorus was sung and repeated. The full lyrics of "Kijk omhoog". Nick en Simon. http://www.songteksten.nl/songteksten/ 76349/nick---simon/kijk-omhoog.htm. Last accessed May 10, 2020. 


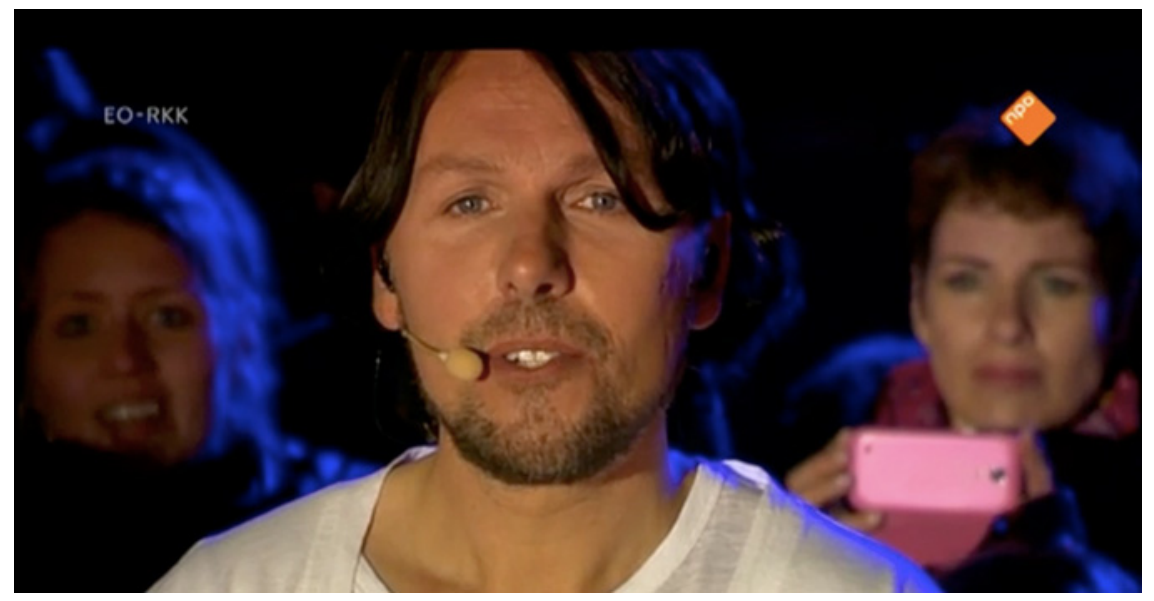

FIGURE 16 The resurrected Jesus (by singer Jan Dulles) appearing amongst people in the square in the 2014 edition of The Passion

SCREENSHOT FROM THE ONLINE BROADCAST OF THE PASSION

in the sense that death is not the end, and there is no dead-end with him. Although this theological construction of The Passion is totally at odds with, for instance, the narrative of Mary Magdalene who takes Jesus for the gardener, in which Jesus says: "Do not hold on to me, because I have not yet ascended to the Father" (John 20:17), the suggestion here is different: holding on to the risen Lord helps a person to let go of everything else (the verse preceding the chorus describes a head full of worries), and to stop searching for answers that apparently do not solve everything. In this reading, in the end, the cloud (of confusion, incomprehension, misunderstanding?) will pass by and the unexpected will occur: Jesus will bring light/enlightenment. Another reading is that, in line with Luke 24:36-53 where holding (on to) Jesus is encouraged so as to emphasize that his appearance is real, Jesus still appears amidst the people: he is still among people right up until the present day.

The choice of the organisers of The Passion to let the resurrected Jesus appear amidst the crowd while singing these lyrics is a statement that makes a clear and fairly direct suggestion regarding the meaning of Jesus: he is a guide to the future, or even the Way. It also makes a strong suggestion as to what an attitude of faith might look like: letting go of everything else and holding on to Jesus; it is staged theology and, more-specifically, staged Christology.

\section{Dordrecht 2019}

Having concluded the event by saying that the message of Jesus is a strong and inspiring call for people to care for others, "so that nobody is alone", the narra- 


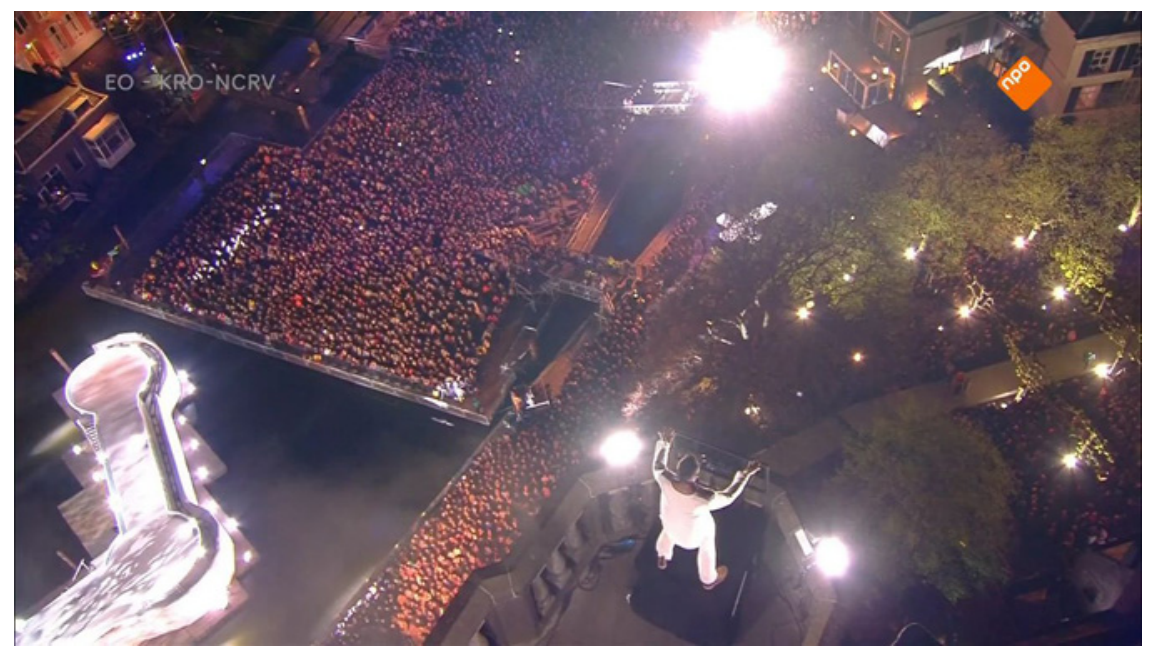

FIGURE 17 The resurrected Jesus (by Edwin Jonker) appearing on top of the Dordrecht Minster above the square in the 2019 edition of The Passion SCREENSHOT FROM THE ONLINE BROADCAST OF THE PASSION

tor gazed up to the tower of the Dordrecht Minster, where the resurrected Jesus immediately took over, singing assuringly to the audience: "You are not alone". This edition played less with the surprise of the apparition compared to previous editions: after mentioning the potential of the performance's message to help people feel less alone, the ritual immediately continued with a proclamation of this reality by the resurrected Jesus, using the chorus of another Dutch pop song:

You are not alone,

I will be there for you.

When it's all far too much sometimes,

I will always be there.

No, you are not alone,

if you need my ear to bend,

if life feels too much,

I will always be there. ${ }^{16}$

16 The translation is mine. Full lyrics of "Je bent niet alleen" available on https:// songteksten.net/lyric/2430/91927/thomas-berge/je-bent-niet-alleen.html. Last accessed May 10, 2020. 
Shortly after the chorus and the verse sung by Jesus, the screens showed footage of the main characters and of the disciples helping out other people: the man who played the role of Peter spoon-feeding a handicapped woman; a female disciple standing together with another young women looking at a smartphone and smiling before the disciple helps to push the wheelchair of the other woman; a guy sitting sadly and alone in a bar before being joined by another male disciple. The theology of this resurrection is that Jesus is present and appears in every person as they keep another person company, spend time with people who are having a hard time, or offer help to those in need practical support. It is a theology of presence - whether around the kitchen table, outside in the streets or in a pub, after and because of the resurrection of Jesus, resurrections among ordinary people can occur in every place where fellow-creatures are looking after their neighbours.

All nine staged appearances expressed theology in their own ways through their staging, and in their choices surrounding screening and the use of lyrics. Every scene of The Passion could be analysed in a similar way, from the recitation of the story by the narrator, to the staging and lyrics used in the scenes of Jesus entering the city, the last supper, the betrayal by his friends, the mocking of the man to be crucified, and of his death. The analysis above shows that a decision to stage the most crucial narrative in Christian tradition in a late-modern 'secularised' society does not necessarily lead to a watered-down version of the resurrection: The Passion is not merely a sound and light show, it is staged theology, and this theology cannot simply be dismissed as 'sloppy'. There has never been (nor will ever be) an authoritative and unchanging model for performance either of the passion or of any other Biblical event: right up into the present day, these forms have always been part of a tradition which constructs, deconstructs and reinvents the presentations of a story that circles around the suffering, death and resurrection of a man who is called the Son of God. In all their different forms, stagings of this narrative express a variety of different theological meanings, and The Passion is no exception.

\section{Production and Broadcasting Companies Doing Theology}

I have isolated the scene staging the appearance of the Jesus character from the rest of the event in order to focus on the ways in which the organisers of The Passion actively expressed theological meaning, and thus asserted theology in public. In order to further interpret the latter, I lean on the theory of John McClure, who, in his book Mashup Religion, challenges the general academic 
conception of the nature of theology by pointing to the world of pop music. ${ }^{17}$ Using contemporary music-making - in which a song is written in relation to a tradition (either in continuity or discontinuity), is sampled across traditions and genres, remixed and mashed up using the latest technologies - as a metaphor, McClure explains how theological invention arises when a mashup of the traditional and the novel is created. McClure argues that "theological invention is a matter of stylistically layering four central authorities (tracks): Scripture, culture, theology and reason". ${ }^{18}$ Referring to the aesthetics of HansGeorg Gadamer, he points out that song-writing within a tradition is a deeply hermeneutical practice: it "is created and comprehended primarily within the horizon of meaning represented by a historical tradition. (...) All new, autonomous, and authentic words are improvisations on a living tradition and gain heteronomy by being beholden to traditions of communication long established and revered within the community itself". ${ }^{19}$ Song-writing out of a tradition means "working from models within a tradition, while "deliberately breaking conventions and forms", adding a "twist and stretching boundaries". 20 McClure pursues the use of popular music-making as a metaphor throughout his book in order to propose a potential shift of emphasis in the theological education of students: they could learn how to 'do theology' by acquiring the skills and knowledge to 'cover' and 'riff on' particular exemplary works within existing theological traditions. ${ }^{21}$ Students can thus learn to handle theological themes and concepts, and to carry these forward in new ways. Focusing "attention on small patterns of behaviour, types of words or phrases, colours, sounds, attitudes, styles, furnishings, habits, expressions", they begin to relate reality to the larger scheme in which these realities exist. More than just applied theology, they thus develop a lived theology. ${ }^{22}$

I suggest that this is exactly what the production and broadcasting companies are doing in case of The Passion. They deal with theological concepts and themes which they then carry forward in a new way. Revitalising a musical form that is deeply rooted in historical Christian traditions, they engage in a

\footnotetext{
17 John McClure, Mashup religion. Pop music and theological invention (Waco, TX: Baylor University Press, 2011).

18 McClure, Mashup religion, 9. McClure makes clear that "not all theological compositions will use all of these tracks, and they will not always be used consistently", McClure, Mashup religion, 55 .

19 McClure, Mashup religion, 15.

20 McClure, Mashup religion, 17.

21 McClure, Mashup religion, 18.

22 McClure, Mashup religion, 37-38.
} 
Christian hermeneutical practice. As they sample Dutch hits, and remix the passion narrative using all kinds of digital technologies, whilst simultaneously engaging through social media, they create a mashup passion that conveys Christian theological messages in a contemporary form. Whether production and broadcasting companies are aware of it or not, through their involvement in the performance of The Passion, they stylistically layer together the four aforementioned central authorities. The 'Scripture track' takes the passion narrative as depicted in the four canonical gospels as its principal point of departure. This track is explicitly referenced when, just before the Jesus character appears, the narrator states that: "Some people said that he will rise from the dead. According to the bible, Jesus himself said this a couple of times..." The 'culture track' becomes visible through, among other things, the organisation of a large multi-media event, the live broadcast of that event, the performance of Dutch pop songs, and the use of technology. In the 2014 construction of the resurrection, the cameras that quickly panned down from the Martini tower in order to display the Jesus figure standing among the audience on the city square are one of the key elements that serve to constitute the culture track. The shape of the 'theology track' has already become visible to us through my earlier description of the theological interpretations that I uncovered above. The 'reason track' (McClure also calls this the 'message track' since it relates to the understanding of religious truth) is harder to discover, particularly because The Passion combines the transmission of theological meaning with its explicit and oft-repeated message that it is up to the meaning maker to decide on the nature of religious truth for themselves.

By layering these four tracks together in a passion event performed in the public sphere, the organizers constructed a theology of the resurrection. This theology is, itself, a performed theology as a natural consequence of the public staging of the event. An academic reconstruction of constructed theologies, as delivered in this chapter, is clearly necessary in order to be able to demonstrate both the nature of this performance as a public theological event and the means by which this performance is carried out. This does not, however, alter the fact that the production and broadcasting companies are also engaged in the performance of public theology.

\section{Public Theology as a Multi-Actor Practice}

In Chapter 2, we claimed that, in late-modern times, the immaterial religious heritage of Christianity (the bible, ritual repertoires, symbols, musical forms, etc.) constantly participates in processes of movement from the ecclesial to 
the cultural or public domain (and vice versa). ${ }^{23}$ Through these processes, religious immaterial heritage moves outside of ecclesiastical structures so as to become a common asset. As such, it simultaneously leaves behind existing ecclesial frames of interpretation, such as those of religious doctrine. Given the fact that western churches are rapidly losing members, these churches are no longer the central institutions in charge of the interpretation of this heritage. People increasingly decide for themselves what the things around them mean: they attribute meaning (including religious meaning) according to their own particular collection of interpretive frames. The way in which religious immaterial heritage (including rituality or, as in our case, large-scale musical forms) is experienced and obtains meaning is affected by the tendency towards individuality that is part of modernity as people are able to deal with these things in their own individual ways. Everyone creates his or her own system of meaning: we are all 'like a spider in a unique web' ${ }^{24}$ As liturgical studies scholar Marcel Barnard put it in the year 200o: "Rites and symbols are increasingly becoming an expression of the unique person which we each are. They have, so to say, become expressions of our own identity. Thus, in addition to reproducing meanings, we are also appropriating them. Moreover, we are not only appropriating them collectively, as groups, but also more and more individually". ${ }^{25}$

In Chapter 4, we discussed how late-modern society is characterised by a 'plural authority structure'; as processes of meaning-making and evaluation have changed, power and authority are now divided. This means that, in processes of interpretation and meaning-making, the dominant ecclesiastical interpretations and meanings which come from the church no longer naturally prevail. This loss of authority on behalf of the church is in keeping with a decline of authoritative institutions in general. Authority and power in the present day no longer fall to central institutions. Just like the church, academia, which has been (some would say: used to be) another authoritative institution in the Western world, seems now to have lost some of the authority which it previously possessed over the course of recent centuries.

23 Gabriël van den Brink, "De migratie van het goddelijke. Over geloof en kerk in de moderne maatschappij”, in Geloven in het publieke domein: Verkenningen van een dubbele transformatie, WRR Verkenningen 13, eds. W. van de Donk et al. (Amsterdam: Amsterdam University Press, 2006), 417-433; Marcel Barnard, “Bijbellezen als textiele werkvorm”, 431-432. Marcel Barnard, Liturgiek als wetenschap van christelijke riten en symbolen (Amsterdam: Amsterdam University Press, 2000), 11 (Inaugural address University of Amsterdam). The translation is mine.

25 Klomp, The Sound of Worship, 4. 
The common man seems often to consider academic reflection and scholarly interpretation to be 'just another meaning'.

Just as the interpretive frame of the church has become just one of many possible interpretive frames, so is the practice of public theology no longer solely reserved to scholars. Academia is not the only place where public theology can be located: in shaping and staging The Passion and thus constructing temporal and situational theologies of the resurrection, the production and broadcasting companies also asserted public theology. Obviously, their public theology is not academic in character and thus not similar to academic public theology (nor does their output take the shape of a scholarly article or book). Their public staging of an event, in the form of The Passion, nevertheless constitutes a ritual practice which has involved a degree of theological reflection. By transforming The Passion into a large media event and simultaneously helping to shape its content, the organisers theologise: they theologically think through their choices, and the event itself reflects their theology. Indeed, The Passion itself is the public embodiment of the organizers' theologising. In their representation of the resurrection as part of a public event, they served to construct theology before the eyes of millions of people.

"Public theology is an engagement of living religious traditions with their public environment", wrote Sebastian Kim in the very first issue of a journal of Public Theology in $2007 .{ }^{26}$ This is exactly what the production and broadcasting companies did: by organising The Passion they engaged with the cultural sphere of everyday life. If academic public theology is to make sense in latemodern society, it has to take societal developments very seriously, and thus also to acknowledge both that the circle of public theologians has considerably widened and that the forms of public theology have begun to diversify. Understanding practical theology as public theology, as I myself do, this acknowledgment offers both important opportunities and challenges when it comes to working and interacting with theological partners in society. These, in turn, will serve to advance the practice of public theology as a whole and contribute to the prominent place of theology in the public sphere.

\section{Ritual Criticism}

Having said this, a particular task remains for the academic practical theologian who practices public theology: she has particular knowledge that makes her an expert in her field, just as broadcasting companies are experts in the

26 Sebastian Kim, "Editorial”, International Journal of Public Theology 1, no. 1 (2007), 1-4, here 2 . 
field of making television and just as particular municipal services have experts who support the organisation of large events in their cities. In this chapter, I have described the ritual creativity that led to a staged theology of the resurrection in various editions of The Passion, and have interpreted the theology of this ritual by means of McClure's theory. Before concluding this chapter, I want to offer an assessment of the ritual in an attempt to "understand specifically in the service of practice". ${ }^{27}$ In the field of ritual and liturgical studies, this assessment is termed 'ritual criticism'. This is a necessary companion to ritual creativity, according to one of the founders of Ritual Studies, Ronald Grimes, ${ }^{28}$ and it is inherent part of ritual play, as Ute Hüsken has claimed. ${ }^{29}$ I will introduce a ritual criticism perspective in order to evaluate the staging of the resurrection, more particularly, the introductions of the final scene by the narrators, with the aim of offering a constructive, or even reflexive, assessment of the rite. ${ }^{30}$

From an etic point of view, I consider the change in the style of the words which introduce the appearance of Jesus and which I elaborated on at the beginning of this chapter, to be a 'performative infelicity': throughout the play, the narrators have acted as presenters of the ritual event, but shortly before the final scene they suddenly withdraw from the play. They zoom out, if you will, in the act of offering an interpretation of the event. ${ }^{31}$ After these interpretative words, the audience is expected to zoom in again, and the play continues when the final scene stages the appearance of Jesus. Towards the end of the event, the narrators thus cause the audience to step out of, and back

27 Grimes, Ritual Criticism, 13.

28 Grimes, Ritual Criticism, 18-19.

29 Hüsken writes that the evaluation of rituals is "an intersubjective process, executed by groups or individuals. It is based on certain sets of values which might stem from canons which the participants themselves have not created, but it might equally be based on the expectations, intentions and agenda of individual participants...". Ute Hüsken, "Ritual Dynamics and Ritual Failure", in When Rituals Go Wrong. Mistakes, Failure and the Dynamics of Ritual, Numen Book Series 115, ed. Ute Hüsken (Leiden: Brill, 2007), 337-366, here 339. As a participant observer, I have been a frequent participant in the ritual of The Passion myself.

30 Grimes states that ritual criticism is contextualist, never absolute, always political, interested, negotiated, dialectical. It can be negative, but it is never just negative: it can also be constructive and at best reflexive. Grimes, Ritual Criticism, 14 .

31 The term 'infelicitous performance' was first used by John Austin in his speech act theory, and used by Ronald L. Grimes in the discussion of ritual evaluation. See Edward L. Schieffelin, "Introduction", in When Rituals Go Wrong, ed. Ute Hüsken, 1-2o. Also cf. Ronald L. Grimes, Ritual Criticism, 191-210. 
into the ritual frame. Their concluding interpretation, which also constitutes the introduction to the very final scene, thus functions as a break. In addition to this, from the 2016 edition onwards, the narrators' interpretations of the passion narrative have become more elaborate and the narrators have struck a different tone, both of which serve to increase the sense of stylistic break as the discourse takes on a somewhat didactic, even prophetic or kerygmatic character. This kind of stylistic shift may be something which is fitting in the context of a worship service, but it fails to work very well in the context of this public play. ${ }^{32}$ For a very brief moment, it turns the narrator into a preacher in disguise. From an emic perspective too, the interpretative speech can be seen as a performative infelicity, because it is at odds with the open and multi-interpretable character of the event. It also adds a ritual inconsistency: although it has been emphasised that the audience is free to choose what to believe and what not, the character and length of this speech suggests that the audience needs to be taught the meaning of the ritual in which they had just participated. Both from an outsider's and an insider's perspective, the words of the narrator at this point can be seen as a ritual 'mistake', not in the sense that they were 'mis-performed', but in the sense that the underlying ritual structure contains an error since the change of style results in a misfitting (sermon-like) element in this particular ludic ritual setting. ${ }^{33}$ The insertion of the sermonette constitutes, then, an internal inconsistency that could be understood as a failure to generate the proper tone or appropriate atmosphere (in Grimes' typology of infelicitous performances this is called a 'flop', as "all the procedures may be done correctly but the rite fails to resonate" ${ }^{\prime 34}$ ).

It is possible to push back on my ritual criticism of this moment on the basis of norms internal to the production: that the makers deliberately let the narrator zoom out in order to introduce the apparition of Jesus as a total surprise following on from the end of the play. The degree of surprise is, of course, relative, since after the first edition there has always been the promise of a spectacular final scene: the resurrection as a grand finale of light and sound. The makers have played with this surprise by offering the scene a new and different

32 Grimes points to the relevance of context when he writes: "What is a felicitous utterance in an ecclesiastical social context is infelicitous in the courts. Fenn demonstrates how context dependent the failure of ritual language is". Grimes, Ritual Criticism, 197.

33 For more elaborate explorations of ritual mistakes and failures, cf. Hüsken, When Rituals Go Wrong.

34 Grimes, Ritual Criticism, 201. 
shape every year, but the promise of a grand finale has always been fulfilled. ${ }^{35}$ If this surprise has become a prevailing internal norm which influences the dramaturgic choice to have the narrator present an apparent conclusion, then the ultimate conclusion of the grand finale is a choice with theological implications; as was alluded to in a number of the later editions, it is implied that with God the end is not necessarily an end and that new beginnings always remain possible.

In the end, however, the question remains as to whether a didactic speech is required in order to prepare the audience for the surprise of Jesus' appearance. An explicit theological interpretation, however openly it may be formulated, seems unnecessary in light of the participant observation and analysis of the staged resurrection in this chapter, which has shown that the final scene of the event offers an embodied theology that is convincing in its own right. The sermonette thus tends to undermine the rest of the performance, depriving the ritual of its own expressive power as the apparition of Jesus becomes, to a certain extent, an illustration in the service of a didactic-cognitive speech, instead of a ritual with a sui generis character. Seen from a ritual perspective, The Passion, in its later editions, sells itself short at this point. The staged resurrection, and the practical theology that it embodies, need no verbal subtitling in any form whatsoever: they are strong enough to speak (and theologise) for themselves. As this chapter has shown, the creators of The Passion lucidly manage to perform theology around one of the most essential elements of Christianity within a late-modern 'secularised' culture. The importance of this theology's public character cannot be underestimated.

35 This is related to what producer Jacco Doornbos has called one of 'the rules of television' ('televisiewetten'): that people like to know what they are looking at. There must be "a clear promise to the TV viewer. And the promise of The Passion is very clear, because, as viewers, we all know the story and that is what we like, but we also like the surprise of who are playing the roles, and how it is shaped this time, and with which songs, and what touches us this time". Doornbos, interview, September 17, 2015 . 


\section{Side Light: What Is This All About? A Letter}

Mirella Klomp, scholar of practical theology and ordained minister in the Protestant Church in the Netherlands, to Christian congregations and parishes in the Netherlands.

Brothers and sisters in Christ,

Greetings! After nine editions of The Passion in our country, and after nine years of research on the phenomenon, I am about to complete a monograph on how Christian religion has changed in the Netherlands. The book deals with new quests for God that may arise in the context of the decline of church membership and church attendance. As church people you may wonder: 'so, what is in it for us?' Having leaned against the energy and will-power of producers and broadcasters for seven chapters, I am now writing to you to share two things the research has brought me. You may find it beneficial.

\section{The Passion Shows That the Impossible Is Possible}

This is the shortest summary of what the research has taught me. To stage an event on the passion of Jesus for millions of people in a late-modern 'secularised' culture would seem impossible, yet it has occurred. I have seen mothers and grandmothers in distress following the cross on Twitter; entrepreneurs and churches objecting to the whole event, people drinking beer and enjoying their view of the square while sitting in window frames, actors of disrepute being allocated leading roles, firemen carrying the neon-lit cross through the rebuilt area of their city. In the seven chapters of my book, a variety of people pass us by - each with their own story and their own meaning-making around the ritual - and I have just mentioned a few; there are many more people, more stories, more processes of meaning-making. The impossible is possible.

The producers and broadcasters also managed to include in the passion the impossible-yet-most-essential-element of Christianity: after the death of Jesus, his resurrection was staged as the ultimate scene of the event. During the closing credits of the broadcast following the crucifixion, cameras zoomed in on the audience in the square, where people were visibly touched by the event, some of them even cried. This resurrection makes visible how people cross the boundary of what is possible. It makes The Passion more than just a cool show of sounds and lights. The event touches upon fundamental grief; 
upon a desire that the death of a child is not the end, or that God can indeed return to one's life; upon the unimaginable occurence that one would ever partake in an event centred on a Christian narrative, either as spectator or as actor. There is life after suffering from an event that confronts an entrepreneur with lost revenues and orthodox Christians with the pain of a sacrilege.

The most exciting thing I learned from the scene of the apparition of Jesus is this: that resurrection is a process that occurs in this reality. The Passion is not just an immense sound and light show staging the resurrected Jesus, it also calls attention to the fact that resurrection can become real when a narrative that exceeds the borders of what is impossible is staged. This process of resurrection occurs not only in The Passion, but also in The Passion. It raises a question for the church to circle around and consider. The church might want to ask whether she herself participates in this resurrection process.

\section{Being Turned into Guests}

Let us go back in time for a moment, to join the two men who are returning home after the resurrection of Jesus (Luke 24:13-35). They are on their way to Emmaus, leaving the impressive events of Jerusalem - the crucifixion of Jesus and the things that took place after his death - behind them, literally and figuratively. They are walking away from the big city, and they are walking forlorn. Whilst they are on the move, discussing all that they have heard and seen, all of a sudden Jesus (a rather public figure! but they do not recognise him) comes near, and asks what they are talking about: "What are you discussing with each other?"

His question can be read as an inquiry regarding the topic of their conversation ("what is keeping you busy?"). It can also (and particularly when read together with the second question: "what things?"), be understood as: "what is this all about?", "these things that you are talking about, what do they mean?" "what is that, then, 'resurrection'?" As Jesus accompanies them on their way, the men respond. They tell this stranger what is on their minds. And they are so occupied with their own experiences, so full of their confusion and sadness, that they do not even recognise Jesus; Luke suggests that they do not seem to be very interested in the stranger; they do not pose him any questions. Do they even care about him?

The Emmaus story raises all kinds of questions about their conversation. Who talks to whom? Who is listening? Who is paying attention to the conversation partner? Who takes whom further in the discussion? Who helps to get a foothold when it comes to making deeper insights, when it comes to recognis- 
ing what matters? These questions are also relevant in a quest for God. Those who undertake a quest for God want to move forward. As church people, we want to learn, grow in faith, come closer to God. We want the church to be meaningful to ourselves and others in our society. We want to get somewhere. The Emmaus story offers a crucial suggestion for this quest: that those who want to make progress would do better not only to focus on what keeps them busy, but also to pay attention to others. Of course, churches are worried about declining membership and church attendance, a shortage of volunteers to organise and support their activities, a lack of clergy ordained to the ministry. Of course, they can consider The Passion to be kitschy, they can get annoyed about the whole event, or consider it to be a banal and desacralised rendition of a gospel narrative that has so many more layers of meaning. But, meanwhile, the question is whether we are really attentive to the other who may be able to take us further.

When they arrive in the village of Emmaus, the men recognise Jesus in the breaking of the bread. He has created the place where they find themselves at home. They realise that they have turned into his guests. They are not hosting him; he is the host at the dinner table. My research on The Passion turned out to do exactly this. Listening to producers, broadcasters and their audience for seven long chapters, paying attention to their questions, their stories, their efforts, made the roles of guest and host gradually change places. Now, after seven chapters, and at the end of the project, I have become a guest of the producers and broadcasters.

What if we are not the ones to decide what happens? What if we let go of the idea that we are the hosts, that we are in the lead? What is the effect of being turned into a guest? The Emmaus story suggests that being a guest is beneficial. My research project has been beneficial to me. The producers and broadcasters hosted the publication of this book, so to speak. But the project has a yield even beyond this book: it has also changed me as a Christian theologian. It has nourished my life in this world and my service in the church with faith, with hesitations and with critical questions. The project itself has turned into a new quest for God, in which I discover myself as a guest, and discover that I was searching (quite publicly) without recognising my quest.

At the dinner table, the men recognise Jesus: their eyes are opened. And, when he has vanished from their sight, they return to Jerusalem (that is, they progress on their way to God) and the conversation continues, not just amongst themselves, but even more so among all the others.

In any quest for God, may an open mind be yours. 


\section{PART 3}

\section{Full-Up Finish}

The final part of this book concludes that the complex transformation of Christian religion in Dutch late-modern society has turned religion into a practice of negotiation. Tapping into a number of disciplinary discussions, it reflects upon the implications of this transformation for Practical Theology as an academic discipline. It characterises the practical theological venture undertaken in this book as play: an interpretation that I risk, in the hope of winning more. 
Mirella Klomp - 978-90-04-44294-8 Downloaded from Brill.com04/26/2023 09:16:19AM via free access 


\section{Playing On: Practical Theology after the Death of God}

Christian religion in the Netherlands has undergone a period of transformation, and this ethno-case study gives an insight into the different forms which this transformation has taken. The Dutch engagement with Christian practices is, in the light of this transformation, characterised by diversity and complexity, and the annual musical performance of The Passion is able to show that Christian religion manifests itself as, among other things, a spatial, ludic, reflexive and public-theological practice that is, in various ways, both ambivalent and contested. Processes of meaning-making surrounding this polyvalent practice relate to the religious, the sacred (not necessarily religious) and to the secular, and this study shows how the boundaries between these different notions have become blurred in public rituals such as The Passion. In these rituals, people are playing and keep on playing with religious heritage. Into their play, I have been able to read a new quest for God.

\section{Religion as a Practice of Negotiation}

What are the characteristics of this play? On the basis of this study, I am inclined to conclude that Christian practices in late-modern Dutch society have turned into practices of negotiation. Of course, (liturgical-)ritual practices through the ages have always involved negotiations, and processes of negotiating religion have existed for a long time. ${ }^{1}$ However, in the context

1 The conclusions of this book align, for example, with observations on processes of religious negotiation in the context of European societies within history, political philosophy, urban studies, and law, as explored in François Guesnet, Cécile Laborde and Lois Lee, eds., Negotiating Religion. Cross-disciplinary perspectives (New York: Routledge International, 2017), adding both a ritual studies perspective and a theological perspective to these explorations. One example of contemporary processes of negotiation might be the ecclesial-liturgical practices of Lebanese Eastern Orthodox women who are married to Protestant men. The work of Rima Nasrallah has demonstrated how Eastern Christian women in Lebanon celebrate Easter: they negotiate the bodily presence of Christ, who "is perceived to be materially very present in the Orthodox liturgical celebration of Easter", but is not perceived to be materially present within Protestant liturgy. In their activities, "a dynamics of negotiation between 
of a society characterised by secularity, by fragmentation, by the continuing multiplication of new options for how to make sense of our world, and by new possibilities for how to give shape to spiritual ambitions in a universe that does not turn around a central point, these negotiations are strongly influenced by a thorough and large-scale diversity, to the extent that negotiation has now become a primary characteristic of contemporary ritual practices. Negotiations, both among groups and between individuals, characterise and surround the practice of Christian ritual in our time and culture; negotiations relating to the (public) space where these practices take place, and can be promoted, contested or obstructed; negotiations regarding how these practices take (and are given) shape in digital media cultures; negotiations around where and whether the sacred/the divine/God is, or is not, encountered; negotiations, evoked by such public ritual practices, relating to how society understands itself; regarding what is 'ours' and what is not; negotiations around the theology that is constructed and the desirability of the particular hermeneutic choices that have (or have not) been made in these practices, and so on and so forth. ${ }^{2}$ Thus - and this would be my answer to the first part of the central question of this monograph as to how Christian ritual repertoire is being transferred, transformed and reconstructed in late-modern Dutch society - Christian religion, in our society, largely seems to have become a bargaining game. This book has shown that the Dutch make meaning from religion by negotiating the meaning of a spatial, ludic, reflexive, and publictheological practice such as The Passion, yet without ever coming to an agreement. They continue to negotiate, playfully, about almost every aspect of the ritual.

Presence and Absence is evident. The women refuse to totally consent to absence, rather in their weaving of the different liturgical traditions they keep negotiating between distance and touch, in other words between presence and absence". Rima Nasrallah, Moving and Mixing. The Fluid Liturgical Lives of Antiochian Orthodox and Maronite Women Within the Protestant Churches in Lebanon $(=\mathrm{PhD}$ dissertation Protestant Theological University), s.l. 2015, http://theoluniv.ub.rug.nl/153/1/NasrallahR_MovingandMixing_18febr2015.pdf, 73. Another example is the negotiation between religion and formative aspects of self, as Phillis Sheppard has pointed to in her womanist pastoral theological reflections. Cf. Phillis Sheppard, "Womanist Pastoral Theology and Black Women's Experience of Gender, Religion, and Sexuality", in Pastoral Theology and Care. Critical Trajectories in Theory and Practice, ed. Nancy J. Ramsay. DOI: 10.1002/9781119292586.ch6, 127-128. Sheppard there mentions aspects such as race, gender, class and sexuality.

2 In fact, as Phillis Sheppard emphasizes, negotiation is itself a meaning-making process, and one that is not necessarily direct and self-evident. Cf. Sheppard, "Womanist Pastoral Theology", 127-128. 


\section{And What about God?}

The terms 'negotiating' and 'bargaining' fit Robert Wuthnow's portrayal of a present-day 'spirituality of seeking', that I described in the introduction, in which individuals are convinced - or at least possess some degree of hope, I would add - that the divine plays a real role in the world, but in which they nevertheless continue to search for sacred moments in order to confirm and reinforce that conviction or hope. ${ }^{3}$ The conclusion that Christian religion in our society largely seems to have turned into a matter of negotiation is thus also in line with a situational approach to the sacred: the idea that the sacred or divine is indeed constructed (found, recognised), and that sacrality is in the eye (or ear) of the beholder. ${ }^{4}$

This situational approach to the sacred has a certain 'danger' to it, however, when considered from a Christian perspective: it runs the risk that the sacred is, in the end, only recognised in positive/good things, as an affirmation of the things which people appreciate. ${ }^{5}$ If the sacred is only to be found in that which moves us in a positive way (it is nice, pure, inspirational, meaningful, beautiful, unifying, healing, empowering; it is love, solidarity, holistic cohesion, agreement, etc.), then this could mean that "there is no sacrality but 'feelgood sacrality". From both historical and systematic-theological perspectives, this view is slightly one-sided: Christian theology has been deeply permeated by different ambiguities and ambivalences over the course of its existence. The meaning of the Christ event is a preeminent example of something with a fundamental lack of stability: its meaning is never fixed, but is always subject to ongoing processes of rediscovery, re-description and reconstruction. ${ }^{6}$ This

3 Cf. Chapter 2 and Wuthnow, After Heaven, 3-4. I emphatically do not equate the play of negotiation with a spirituality of seeking: this would mean that I would classify all those who engage in negotiation around a Christian ritual such as The Passion into spiritual seekers, which would be problematic.

4 On the situational approach to the sacred, see Chapter 4.

5 This situational understanding of the sacred was frequently encountered in the field, particularly among people in the city squares, but also on the internet (e.g. on Twitter, Facebook and the virtual procession). It can be characterised as an 'ordinary theology' (cf. Jeff Astley, Ordinary Theology: Looking, Listening and Learning in Theology, Explorations in Practical, Pastoral and Empirical Theology (Aldershot: Ashgate, 2002), or an 'espoused' theology (cf. Helen Cameron, Deborah Bhatti and Catherine Duce, Talking About God in Practice: Theological Action Research and Practical Theology (Norwich: SCM Press, 2010)).

6 The four gospels, among other canonical biblical texts, already demonstrate that there has been a (turbulent) search for a single stable Christian identity. Cf. Peter-Ben Smit, "Authority in the New Testament and the New Testament's Authority", Eccesiology 13 (2017), 83-101, here 96-97. Also cf. Judith Gruber, Theologie nach dem Cultural Turn: Interkulturalität als theologische Ressource (Stuttgart: Kohlhammer, 2013), in which the author claims that ambivalence 
implies that when the sacred/the divine/the Other fully coincides with or affirms our own ideas, beliefs, or convictions, but fails to goes any further, the theologian has reason for suspicion. Christian theology has indeed always left some space for an unexpected or uninvited approach by the Other, a 'coming from the other side': the human self is not the ultimate point of departure, and ' $\mathrm{I}$ ' am not the centre of the universe, but, time and again, I become part of the greater story of God. Indeed, the gospel basically turns things upside down: those who think they know God, are proven wrong. ${ }^{7}$ This implies that a situational approach to the sacred, from a Christian perspective, not only finds traces of God in positive meaningful experiences that confirm our own opinions, but also in the unpleasant surprise, in the nasty, in things that itch, the argument, in conflicts and ambivalences, in places where interaction goes back and forth, where there are pros and cons, offers and counter-offers. Indeed, traces of God can also be found in the conflicts that surround (public) rituals with Christian roots.

\section{God's Play}

The transformation of Christian religion into practices of bargaining and negotiation will be grist to the mill of those who see in contemporary practices the decay of Christian religion (critics of The Passion in the media, both Christian and non-Christian, have described the event as a symbol of such a decay). In my theological view, practices of negotiation are nothing that a society should be ashamed of, nor are they unlike God. After all, to negotiate is to play, and, in this book, I have staged God as a playful God. The question could arise, however, as to what God's response to this negotiation might be. As this book is drawing to a close, I will not offer an exhaustive list of possible responses, but I will offer one suggestion, based on a famous Biblical narrative of a man negotiating with God, and a peculiar commentary on one particular verse of this narrative.

In Genesis 18 (verse $16 \mathrm{ff}$ ), the men (angels) who had visited Abraham and Sarah by the oaks of Mamre set out from there, and Abraham follows them.

is at the heart of Christianity. Smit even goes one step further by claiming that the ambiguity and the recontextualisation of Christian tradition are necessary for its further development. Cf. Peter-Ben Smit, Traditie als missie. 125 jaar Unie van Utrecht - 1275 jaar in de voetsporen van St. Willibrord (Amersfoort/Sliedrecht: Oud-Katholiek Boekhuis/Merweboek, 2015).

7 This insight can be found in a wide range of theological streams, ranging from Karl Barth's idea of God as 'der oder das 'ganz Andere' who breaks in upon us 'senkrecht von oben' to the work of practitioners of liberation theology, queer theology, etc. whose theologies circle around the idea of a preferential option for the poor and vulnerable. 
Abraham then discovers that God has the intention of wiping out Sodom. In a very polite manner, taking on a role like that of a market vendor, he starts to negotiate with God: in Sodom, the lives of hundreds, maybe thousands of people are at stake. "Will you indeed sweep away the righteous with the wicked?", Abraham says, and he comes up with his opening offer: "Suppose there are fifty righteous within the city...". In the end, Abraham succeeds in having God change the plan. God plays along with Abraham. Or actually, it may have been the other way around, as the set of critical texts which comment on the Hebrew Bible (the Masorah) suggests. A few verses prior to Abraham's negotiation, in Genesis 18:22, the text reads "... while Abraham remained standing before the Lord". According to a critical note in the Masorah, however, "this is a correction of the scribes [rather than saying] that the Shechinah (Divine Presence) would wait for Abraham". ${ }^{8}$ This draws attention to a contested issue, with a refined explanation: of course, it was the other way around: God waited for Abraham (as God was walking in front and Abraham followed), but it would have been irreverent to say so. ${ }^{9}$ This critical note suggests that it is not so much Abraham, but God who actually takes the initiative in the play: it is God's game. God remains standing in front of Abraham and shares his intention to destroy Sodom, as if God expects Abraham to come up with objections. God waits for Abraham. By objecting, Abraham indeed plays along with God, and by bringing in the righteous as a reason to spare the city, he eventually negotiates that only ten righteous people are enough to avert the destruction and to preserve life in the city.

The heart of this Biblical story, in my view, is that God displays an openness to Abraham's wager. God's play, then, may also include an openness to our wagers. The outcome of these negotiations is unsure: when Abraham lets go of his first bid, a space of uncertainty is opened up in which he risks something. Similarly, the outcomes of people's rituals and meaning-making activity - whether 'religious', 'sacred', 'secular', a mixture of these or anything in between - are uncertain. Our negotiations as homo ludens are wagers by which we enter a playful space of "not-knowing", where possibilities are opened up. In this playful space, Deus ludens may keep on waiting for us.

8 From the Midrash Bereishit Rabbah 49,7 (a midrash with a collection of rabbinical homiletical interpretations of the book of Genesis). The quotation is from Rabbi Simon ben Pazi. Source: "Bereishit Rabbah 49", Sefaria, https://www.sefaria.org/Bereishit_Rabbah.49?lang= bi. Last accessed May 10, 2020.

9 It would not have made sense that they walked towards Sodom and that Abraham remained standing before the men/the Lord, as Abraham did not walk in front of them. Rabbi Simon's critical note deals with this inconsistency. 
Thus, returning to the central question of this monograph, and the second part of this question in particular - the question of where traces of God might be found in this newly appropriated ritual repertoire in our society as it is transferred and transformed - I take the practice of bargaining that Christian religion has become as a playful wager: it opens a space of negotiation in which God may return. A space of negotiation in which self-declared atheists, as well as those who see no way to live up to a spirituality of dwelling, of going to a place where they know they will find God (be it houses of worship, liturgical rituals, or church denominations to belong to), and 'floating believers' as well as those who wager their atheist positions, might experience the counter-offer of the Other. A space of negotiation in which Christians with more or less fixed ideas of the way that things should be (either 'in God's eyes', or according to their faith, hermeneutics, or theology) might gain new insights, finding traces of God in the counter-offers of individuals or groups of unlike views. Christian religion as a bargaining practice can enable people to find a God who stands waiting before them, in the ambivalence, the objection, the counteroffer of the other. Indeed, traces of God can be found in the places that one least expects: in processes of negotiation in and around contested spaces, in ludic practices, in the public efforts of societies to understand and act upon themselves, and in the staged theology of producers and broadcasters.

\section{Aspects of Loss}

We must not ignore the fact that this transformation also has an aspect of loss. Christians who have not been enthused about The Passion, in particular, seem to have experienced this sense of loss: they have criticised The Passion's spatial, ludic, reflexive and public-theological practices for being too mundane or too popular, for neglecting the prophetic aspects of the narrative of Jesus' suffering, death and resurrection, and for a lack of proper hermeneutical interpretation, considering it to be too 'Biblicist', 'too historical', offering too much comfort, lacking challenge and nuisance, or pursuing emotional rather than transformative experiences. ${ }^{10}$ They have also criticised it for its one-off, no strings attached, character as its annual performance contrasts strongly

10 See for example Hendro Munsterman, "Briefwisseling The Passion - De derde brief", NieuwWij, April 9, 2015, https://www.nieuwwij.nl/themas/briefwisseling-the-passion-de -derde-brief/, where the author suggested challenging the viewers by having a real washing of feet as part of The Passion: the feet of homeless people, bankers, voters for right wing political parties, asylum seekers, bus drivers, hairdressers, victims of sexual abuse, garbage men, rabbis and imams, prostitutes, detainees, paedophile fathers, and even celebrities. 
with ideas of weekly-church-attendance-whether-you-like-it-or-not. Although these criticisms sometimes lacked a sense of reality, since they ignore the secularised context of the public sphere and the fact that The Passion was not a church event, but was organised by a production company and two broadcasting companies with Christian backgrounds, there was and is indeed a loss when churches are taken as the frame of reference.

I experienced this feeling of loss myself when in 2019, for the first time since 2011, I celebrated the 'classical' Maundy Thursday liturgy in our own congregation, before rushing home to switch on the $\mathrm{TV}$ in time in order to watch The Passion; I realised with a certain wistfulness that, unwittingly, I had actually missed celebrating Mass, and the intimacy and solemnity of some forty people performing the ritual together on Maundy Thursday. I also often encountered this feeling of loss when people started to vent their frustrations during the Q\&A sessions which I have given after talks in parishes and churches throughout the country since 2011. They have often asked me questions that display a sincere concern regarding the downfall of Christianity. In doing so, they often take Christian liturgy as their normative starting point. "Interesting talk, it's all fine, but The Passion is of course soooo superficial", is one of the most frequent responses that I have received, in different variations. "Why of all days must they organise The Passion when we celebrate Maundy Thursday? Couldn't they just choose another evening for this event? It is so inconvenient that they have this in our city on this particular evening...", a regular church-goer complained. Or, in the words of an ordained minister: "Some of our really engaged church members no longer come to church for our Maundy Thursday liturgy, but instead stay at home to sit on the couch and watch The Passion. And I don't know how to respond". I have always tried to acknowledge the hurt that is often hidden behind these remarks: to the different questioners, Christian worship is the standard, the norm, and it is not surprising that these transformations of ritual practices are considered to be a loss from their perspective.

An interesting question, however, is why church-people's meaning-making around a hymn or sermon in Sunday worship would be more genuine than television viewers' meaning-making around Peter's betrayal of Jesus and their relation of this narrative to experiences of betrayal in their own lives? Why should people, sitting in the windows of their houses, drinking beer and enjoying their view alongside the squares where The Passion was staged, be any different from those celebrating worship while sitting in monumental churches, enjoying the lights coming through the stained-glass windows and getting carried away by the sounds of the organ? Who are Christians to consider people's meaning-making around The Passion to be cheap or even loathsome? Who are they to decide whether or not those without any knowledge of the 
passion narrative experience the sacred/the divine/the Other in this event? Here, being certain could mean being wrong: such views could run the risk of being condescending. And unnecessarily so: if God indeed responds to negotiation with openness and keeps on waiting, then God can probably take it, even when some of God's people find this wager uncomfortable or inconvenient.

\section{Performing Practical Theology after the Death of God}

It is widely acknowledged that the discipline of practical theology is characterised by a great deal of diversity, complexity and interdisciplinary fragmentation. Ecclesiastical, academic, social and cultural contexts influence how the discipline understands itself, and fundamental differences are the result: there is no shared understanding of what practical theology is. Nevertheless, definitions and descriptions of the discipline often somehow include terms such as 'faith', 'human belief', 'Christian life' or 'Christian community'.1 At the Protestant Theological University in Amsterdam, the practical-theological research program in which I carried out my research on contemporary Passions in the public realm developed a focus on 'practices of faith in socio-cultural networks'. With this focus, the program took an empathically open, dynamic and situational approach to the study of "new, usually complex and fragmented developments in practices of faith. The fading [of] church boundaries and the mixture of traditional faith and new spirituality on the one hand, and a renewed emphasis on strict protestant practices of faith in varying degrees on the other, position practices of faith both within and outside the church in the narrow sense". ${ }^{12}$ My own research clearly relates to the first part of this last sentence (fading church boundaries and the mixture of traditional faith and spirituality). However, after eight years of research on The Passion, I wonder

11 E.g. "Its greater aim is to foster richer material understandings of embodied theology so that those who practice ministry and pursue lives of Christian faith will have a greater sense of their theological and religious vocation". Bonnie Miller-McLemore, "Five Misunderstandings about Practical Theology", International Journal of Practical Theology 16, no. 1 (2012), 5-26, here 26. "Practical Theology is 'practical', and 'theology', only when it is shaped by the ordinary practice of the Church". Pete Ward, "The Hermeneutical and Epistemological Significance of Our Students. A Response to Bonnie Miller-McLemore", International Journal of Practical Theology 16, no. 1 (2012), 55-65, here 64.

12 For a full description of this research program, see Marcel Barnard, "Practices Research Program", Protestant Theological University, https://www.pthu.nl/Onderzoek -PThU/Practices/onderzoeksprogramma-practices.pdf. Last accessed May 10, 2020. 
whether the term 'faith' as a qualifier of 'practices' might be too narrow in the context of this ethno-case study. 'Faith' can be understood in a very open sense to mean something like 'worldview', but when combined (or used in a text) with terms like 'religion', 'belief', 'spirituality', 'Christian', etc., the understanding of the notion of 'faith' is narrowed and the interpretation is steered in a particular direction. These terms, when used in practical theological contexts, categorise practices in ways that are sometimes unfitting: they are problematic in research about the transformation of Christian rituals in the public realm of a secularised society where there is significant religious illiteracy, and where many people do not consider themselves spiritual at all, and would never dream of talking about traces of the sacred/the divine/the Other. Even relating their engagement to a 'spirituality of seeking' would be too much for the engagement of some, and would do little justice to their experiences since many of the people engaged in the practice of The Passion are neither convinced, nor do they have some degree of hope, that the divine exists, let alone search for sacred moments to confirm and reinforce that conviction or hope. ${ }^{13}$ The problem of naming a public event like The Passion as a 'practice of faith', even when 'faith' is taken in its widest sense (e.g. as worldview), is that a single name is given to people's diverse and fragmented engagements with a practice that sometimes cannot be captured by the language of 'faith' at all. I imagine that a great number of people whose meaning-making I examined as part of my fieldwork, if they were aware of this 'faith-bias', would perhaps refer to it as 'theological land-grabbing' or even 'theological imperialism'. They were not, so they did not, but I could understand them if they did.

My feeling of discomfort with an understanding of practical theology as the study of practices of faith relates to what Tom Beaudoin has pointed out as one of the conundrums of the discipline. In his book chapter on the conundrum of the theological significance of practice, Beaudoin writes that "practical theologies render practice as divine material" before problematising the place of Christianity in practical theology. ${ }^{14}$ Beaudoin questions paradigms of "Christian-Centrism", claiming that practical theology, at least in the USA, "has not done well enough at letting the religious "other" into the theological sense it makes of practice; neither has it allowed much wisdom and experience from non-affiliated/secular persons". ${ }^{15}$ His conundrum regards the question of why

13 To refer once more to Wuthnow's 'spirituality of seeking'. Wuthnow, After Heaven, 3-4.

14 Tom Beaudoin, "Why does practice matter theologically?" in Conundrums, eds. Mercer and Miller-McLemore, 8-32.

15 Beaudoin, "Why does practice matter theologically?" 12. 
practical theology has not been met with friendly criticism from within relating to the question of why practice is theologically significant. ${ }^{16}$ "Predication and affordance are pitched toward making practice a continuation of Christianity, and making Christianity live continually in the presence". ${ }^{17}$ This invention of Christian experience, investment in the reproduction of Christianity, or religious identity building, is widely called 'christianicity'. ${ }^{18}$ The practice of practical theology as an academic discipline in Europe is slightly different from what Beaudoin describes; in the Netherlands, for example, practical theologians often study practices and praxis that are situated in broader cultural fields and which are not necessarily or unequivocally Christian. ${ }^{19}$ I have, in this book, refrained from claiming that the event of The Passion is simply a continuation of Christianity: in the first chapter, I wrote that The Passion is, and at the same time is not, a (Christian) religious phenomenon. ${ }^{20}$ 'Practices' need not necessarily be 'practices of faith' to be able to be interpreted as a quest for God. 'Faith' is not necessary for this quest: practices of 'unfaith' may equally lead to searching for and finding God. As historian and philosopher of religion Gerardus van der Leeuw in 1933 wrote: "God (...) is a late-comer in the history of religion", suggesting that there is a lot of religion before God shows up, and perhaps also that God is to be found among us only for a short while. ${ }^{21}$

16 Beaudoin, "Why does practice matter theologically?" 15.

17 Beaudoin, "Why does practice matter theologically?" 18.

18 Beaudoin, "Why does practice matter theologically?" 18, esp. footnote 16.

19 Cf., for example, Ganzevoort and Roeland, who write that: "The attention for such variegated practices within practical theology clearly signals an evolution of the discipline. Whereas the term "practical" used to refer to the praxis of ordained ministry and - more recently - to practices of Christian faith communities in a broader sense, it nowadays includes much more. Many praxes or fields of moral, existential, and religious practices are of interest for practical theology. This includes conventional fields like care, education, church, and politics, but also fields like media, leisure, and sport. In principle, every praxis carries potential topics for practical theological research". Ganzevoort and Roeland, "Lived religion", 96.

On the way in which the arts (specifically the paradox of the image) can (or should?) influence the practice of both Christian faith and academic practical theology, cf. Marcel Barnard, "Ambivalent Images. Rethinking Biennale 52 Venice/ Documenta 12 Kassel and the Task of Practical Theology", International Journal of Practical Theology 14, no. 1 (2010), $68-85$.

20 Beaudoin himself mentions that, in cultural contexts outside of the US, the discipline has started to promote non-ecclesial and non-Christian approaches to practices. See Beaudoin, "Why does practice matter theologically?" 17-18 and, on p. 18, footnote 15.

21 Gerardus van der Leeuw, Religion in Essence and Manifestation. A Study in Phenomenology [transl. from the German: Phänomenologie der Religion, Tübingen 1933] (New Jersey: Princeton University Press, 2014 [1938]), 104. 
The opposite is also true. Faith does not necessarily imply a searching for and finding of God, as Dietrich Bonhoeffer in 1944 discovered when he sought to explore 'religionless Christianity', thus ridding the God-question from the religious baggage that had become a meaningless millstone to people. ${ }^{22}$

In this book, I have not aimed to turn the practice of The Passion into simply a continuation of Christianity. I have, together with the organisers, participants and other individuals in the public sphere, reflected on this practice, and interpreted it. And I have reinterpreted this process from a Christian theological perspective as a quest for God, understanding these practices as material (performances, experiences and/or meaning) in which the divine may or may not be encountered, thus adding to a discourse of God after God. So, in response to the conundrum, as phrased by Beaudoin, of why this practice matters theologically, I would say that a Christian reading of public ritual practices such as The Passion opens the possibility of discovering new ways to speak about God after God, and of finding traces of God in late-modern reality. This ethno-case study, therefore, does indeed read theologically significant practices (of both faith and unfaith) in ways that "make a new spiritual situation - irreducible to what has come before". 23 This does not, however, legitimize a univocal understanding of the research object of this practical theological work as a 'religious practice' or a 'practice of faith'. The study serves rather to destabilise notions of (Christian) faith, belief, and spirituality. The religious/secular 'ethnos' which I have investigated consists of millions of people living in a polarised society, and is tremendously diverse and fragmented

22 Cf. Bonhoeffer's letter to Eberhard Bethge, April 30, 1944. Dietrich Bonhoeffer, Letters and Papers from Prison, [transl. from the German: Widerstand und Ergebung. Briefe und Aufzeichnungen aus der Haft, München 1951] (New York: Touchstone, 1997 [1953]), 28o282.

23 Beaudoin, "Why does practice matter theologically?" 29. It will be clear that I have not sought to apply 'traditional' ideas of God to new ritual practices in new situations or contexts. Nor have I intended to identify God for people for whom traces of God are not real or do not matter. Rather, and much to my surprise, the (disciplinary) openness with which I have performed this academic research appears to tolerate God very well, and vice versa. This book thus does not 'open' a God who was 'closed' or 'locked up' in the tradition: after God, the openness of the God of the Christian tradition appears to be able to come out of this tradition, time and again. After God, the God with which Christianity has concerned itself appears not to be a closed concept. Although I feel at ease with the academic discourse presented throughout the book, the reflexive Side lights in particular have helped to discover this. To me, and perhaps to any reader who undertakes a quest for God, these Side lights have reached out even more than the arguments offered in the chapters, which is why I have presented them as interstitial reflections instead of integrating them into the overall narrative of the book. 
in itself and, as I have shown, even these categories are not always appropriate or helpful for a better understanding of what is going on in late-modern society. This does not solve the 'faith-bias'; I have no alternative term that captures the kind of practices and the overwhelmingly broad and complex processes of meaning-making it includes, other than, perhaps, meaning-making itself (in our case: meaning-making as embodied practices of play; future exploration of the adequacy of this definition may be worthwhile). The conundrum remains a conundrum, at least for now. ${ }^{24}$

Having problematised the term 'practices of faith' in relation to the practices that have been described in this book, I will complete this chapter by presenting my view of what the study offers: a provisional and situational effort to perform practical theology on the transformation of Christian ritual practices, such as those described in this study, in 'post-secular' societies.

\section{Practical Theology as Public Theology}

Chapter 2 has already revealed how I understand practical theology in the context in which I live, work and theologise. As a practical theologian in a Dutch context where Christian rituality has moved towards the outer-ecclesial domain and has undergone radical transformations, I take it as my task to give a theological reading of practices of faith in the public sphere that constitutes my field of research. ${ }^{25}$ However, I do not just theologise on the public practices of individuals and groups, I also theologise in the public sphere, on their practices in the public sphere. During the past eight years of research on contemporary passions, and on The Passion in particular, I have offered my reflections in the public sphere, for numerous microphones and cameras, in newspapers and other print media, as a guest in TV talk shows, in interviews, in op-eds, during parish talks and in public correspondence published on internet websites. ${ }^{26}$ Particularly in the interactions with the media, this has been quite a venture: I have frequently found myself performing public theology on a public practice in the context of a public discourse in which God is consid-

24 Addressing or specifying a conundrum is a way, however, to further a theological project "with respect to the rhetorical parameters and political stakes of a historical moment", as Beaudoin rightly states. See Beaudoin, "Why does practice matter theologically?" 15.

25 This does not alter the fact that others are also doing public theology in/on the practice of The Passion: in Chapter 7, I defined public theology as a multi-actor practice, pointing to producers and broadcasters doing theology at the grassroots' level, i.e. in public, in their own right and in their own way.

26 Most of these reflections ended up in this book and helped me to perform this complex task. 
ered to be dead; ${ }^{27}$ a fairly complex, but challenging play! I have received letters, postcards, emails and direct messages via social media from people who agree or disagree with me, and who have offered their own questions or reflections for me to ponder on. I have also received a number of thank-yous from people who had been wondering what to make of The Passion, and who have used the perspectives that I have offered for their own reflections. I have regularly had the thought, both during and after these interactions, 'And this is the reason why I became a theologian'. The unprecedented speed at which ideas, cultural values, money, and information move through informational societies can be confusing for many people. How should they form their own opinions about complexities that are not easily understood? One of the duties of scholars in the humanities in general, in my view, is to offer informed reflection upon and interpretation of complex phenomena for a wide public. And this is why I perform public theology, it is something that I carry out for anyone - whether devout believers, floating believers, agnostics, atheists or the 'ignorant' - who is wondering what to make of contemporary appropriations of Christian religion in a changing world. As much as I have written this monograph for peers in academic practical theology, I have also written it for professional theologians (in all kinds of fields), and for any other readers who are involved in either their own quest for God or that of others. My works as a 'public practical theologian' will continue. This monograph is not the end of my journey, it is a temporary standstill, a stopping point on the way. Theory is indeed travel. ${ }^{28}$

\section{Practical Theology as Play}

In my practical theological work in the public sphere, I have sometimes offered my interpretations to people to play with. Sometimes people are challenged by the reflections and interpretations that I offer, and sometimes I have been challenged by other people's objections or interpretative counter-offers. As much as the ritual of The Passion is a practice of negotiation, its interpretation was also, and still remains one too. This ritual event, which took place in the public sphere of a society that is ambivalent in its religious selfunderstanding, can invite people to make a wager as it challenges them to let go of fixed ideas on religion and secularity, and to engage in a ritual practice that might lead to different/deeper/embodied knowledge on these issues. And it may invite people to take part in the ultimate wager; the greatest wager is God.

27 I.e. the public discourse that sticks to the stubborn image of the Netherlands as a secularised country, in which God is becoming more and more dead; see the Prologue. 
This academic monograph is also a form of play; it is play, more than it is a goal-directed enterprise or an efficacious discussion of a problem. ${ }^{29}$ Theology can be described as a discipline in which we talk and theorize about God, but it could also be described as a discipline in which we investigate how God talks about us. In this book, I have, at some points, explicitly played with the 'as if'-character of God's perspective on us, thus reflecting the fact that our object of research, God, is not bound by our view of this object. These reflections are essentially playful, as they subjunctively combine our reality with God's reality. More generally, I am by no means convinced that dealing with the research problem in the way that I have done so in this book is the 'right' choice. I have tried, however, to offer a meaningful contribution to the interpretation of what is going on with religion. It is serious play, as is scholarly research in general. Through research we simultaneously combine together multiple realities together in the same place: in a playful search for answers to different questions and problems, we combine reality as it presents itself to us with the reality of (one or more) possible interpretations, thus exploring new ways of seeing things. A side effect of my academic play is that it has changed me as a theologian: when I started this passion project, I had little idea what I was getting myself into. Now, at the end of the research and this monograph, I still do not know it, but in a different way. Between the first day and the last day, the first page and the last page, I have embraced a different way of thinking about God. The enterprise of reading a quest for God into the ritual practices of The Passion, has brought moments of creative 'not knowing' that have, to borrow a phrase from Kearney, opened up "novel possibilities of meaning" that may be valuable to theology, and have certainly been valuable to me. ${ }^{30}$

Playing with the question of where God can happen after God, this monograph accommodates a wager on two levels. Firstly, there is the level of secularised society: if we let go of the claim that secularity advances as Dutch society progresses, then taking part in the wager offers the option for people to discover more of the sacred than they, whatever their worldview, are usually inclined to see. Secondly, if we abandon the belief that God has almost

29 Joyce Ann Mercer, when comparing the expertise of practical theologians and the expertise of jazz musicians, described the first as having, among other things, the ability to play with unconventional combinations of theory from diverse fields, and the latter as having the ability to play with the unconventional combinations of notes that constitute jazz music. Joyce Ann Mercer, "Interdisciplinarity as a practical theological conundrum", in Conundrums, eds. Mercer and Miller-McLemore, 163-189, here 174.

30 Kearney, Anatheism 7. Also see the Prologue where I have characterised this monograph as an effort to ritually think through the anatheistic project. 
disappeared from the Netherlands, but instead engage in a new quest for God, the wager opens a space to discover God after God, and to discover how God returns to humans. In this wager, there is the possibility that faith may or may not retrieved: God as a Deus ludens is an uninvited visitor, a Stranger who may be met with either hostility or hospitality. On both levels, there is the idea of a stranger (in the form of a transformed Christian religion and of 'God') presenting itself and challenging people to do something with it. On both levels the basic question is: do you want to get on board, do you wager on seeing God return in new ways? In the end, it is not about claiming the truth, or stating how things are, but how we see them. This also goes for the practical theological play that I have undertaken. The death of God invites us to return to creative and original play that is open to new things. It is all about the challenge to interpret things from a different perspective, to create new meanings, to set aside our certainties and our absolute talk, in order to enter the space where we may or may not see something new and unexpected; where we may or may not encounter God after God. It is all about the invitation of the Stranger to play on. 
Mirella Klomp - 978-90-04-44294-8 Downloaded from Brill.com04/26/2023 09:16:19AM via free access 
APPENDIX 1

\section{Research Methodology}

\section{Qualitative Research}

Qualitative research is broadly 'interpretivist' in nature, as it is concerned with how the social world is interpreted, understood, experienced and produced. ${ }^{1}$ Since the research question of the passion project underlying this monograph regards the transfer, transformation and reconstruction of Christian ritual repertoire in Dutch late-modern society, and the search for traces of God in this newly appropriated ritual repertoire, qualitative research methods seemed to be the more appropriate tool to employ. Over the years, sociologist Jennifer Mason's formulation of some of the difficult questions that can be raised when considering intellectual puzzles and research questions have been helpful in structuring and re-structuring the research design: 1. the ontological perspective; 2 . the epistemological position; 3 . the broad research area; 4 . the intellectual puzzle; 5 . the research questions; 6 . the aims and purpose. ${ }^{2}$ In all these questions the active reflexivity of the researcher is at stake. I have already discussed questions 3, 4, 5 and 6 in the Prologue, but here I would briefly like to dwell on the ontological and epistemological choices with which the researcher is confronted. In this section I will ground myself on ontological and epistemological reflections and elaborations that can be found in previous research on ritual. ${ }^{3}$

The ontological perspective concerns the researcher's view on the nature of the entities that are investigated. In this book, I take these entities to be ritual practices in the broadest sense, and I likewise understand participants in the broadest possible sense (e.g. I also consider a newspaper columnist or blogger who writes on The Passion to be a participant). A ritual, however, is more than its actual performance: the ritual is also interpreted, understood, experienced and produced. I distinguish between four different layers in the ritual practices of The Passion: ${ }^{4}$

1. the ritual practices as perceived by the researchers and the participants (e.g. those involved in shaping the ritual, or who participated in the performance of The Passion by attending the ritual on the square/in the procession/via social media/by watching on TV);

1 Jennifer Mason, Qualitative Researching (2nd edition) (London: Sage, 2002), 3.

2 These questions are presented as 'six important questions' in Jennifer Mason, Qualitative Researching (3rd edition) (Los Angeles: Sage, 2018), 3-19.

3 Barnard, Cilliers and Wepener, Worship in the Network Culture, 49-63 (a chapter in which I was a co-author), partly based on Klomp, The Sound of Worship, 97.

4 Barnard, Cilliers and Wepener, Worship in the Network Culture, 54.

(C) MiRELLA KLOMP, 2020 | DOI:10.1163/9789004442948_015

This is an open access chapter distributed under the terms of the CC BY-NC 4.olicense, Klomp - 978-90-04-44294-8 
2. the reconstructions of the ritual practices by the (same) researchers and participants (e.g. people's comments on The Passion in the media and via social media; things people told me during interviews; fieldnotes taken after participatory observations on the square, during and after meetings held by the organisers);

3. the interpretation of the ritual practices by the researchers and the participants as they reconstruct their perceptions at a later stage (e.g. organisers who reflect on the phenomenon that The Passion has become on TV talk shows; theologians and others who publicly interpret the ritual in the media, also: the interpretations that are offered in this book);

4. the interpretation of the interpretation of the reconstructions in further academic discussions and societal and ecclesial discourse (e.g. previous academic and professional publications on The Passion, this book as a whole, and, based on this book: my activities of knowledge dissemination in the public sphere, church leaders that use the book for study groups in their churches, the use of the book in education, e.g. for students training for the ministry, or postacademic training of clergy, etcetera).

None of these levels 'is' the ritual, and on all levels various actors take part in various discourses that are part of the ritual discourse.

My epistemological position that, in this research project, knowledge of reality is acquired by various actors, namely the researchers and participants, relates closely to these different levels. Participants acquire embodied knowledge by participating in the ritual (level 1), the researcher excavates this knowledge in the form of data by means of an ethnographic approach (for example through immersion and participation in ritual settings; level 2). ${ }^{5}$ The researcher interprets this interpreted knowledge using theories from different disciplinary fields (level 3), and relates this to interpretations that arise in academic discussions and societal and ecclesial discourses in a cyclical process (level 4). The type of knowledge that his project yields is thus not focussed on getting to 'evidence' or even 'truth'; the knowledge generated by the ontological entities takes, rather, the epistemological form of perspectives and arguments.

\section{Meta-Theoretical Choices}

Practical theologian Richard Osmer, in an article published in 2011, has explored two levels at which paradigms influence practical theology today. ${ }^{6}$ The first level is that

5 Mason mentions the ethnographic approach as one example of "epistemological approaches in the social sciences and what they imply about how knowledge is derived", Qualitative Researching (3rd ed.), 8.

6 Richard Osmer, "Practical theology: A current international perspective", HTs Teologiese Studies/ Theological Studies 67, no. 2 (2011) \#Art. 1058, 7 pages. http://dx.doi.org/10.4102/hts.v67i2 .1058 . 
of reflective practice, and the second is the meta-theoretical level, at which the researcher takes decisions that influence the shape of their research. Osmer states that practical theologians must explicitly or implicitly deal with at least four metatheoretical issues: models of cross-disciplinary work, the theological rationale that justifies their approach, the theory-praxis relationship, and sources of justification. In my Prologue I have already mentioned that I take a transversal approach regarding crossdisciplinary dialogue. I will here further reflect on the relationship between theology and the other disciplines, and then briefly address my choices with respect to the other three issues.

The transversal approach is based on "a fluid and dynamic understanding of the relationship between the disciplines". ${ }^{7}$ Values and perspectives intersect in the new knowledge that is created in this cross-disciplinary dialogue. In this practical theological study, I have taken up theories from a number of disciplines (mostly philosophy, anthropology, digital media studies, sociology, and theology) to shed light on the transfer, transformation and reconstruction of Christian ritual repertoire from various complementary perspectives. Particularly in Part 2, each chapter and disciplinary perspective is independent of other chapters, yet, I wrote these chapters and formed these perspectives in the context of a practical theological dialogue (i.e. this book) that intends to add to a profoundly theological discourse (the God-question). No disciplinary perspective in this conversation can be reduced to any of the other disciplinary perspectives. This also holds for theology, which is a discipline in its own right. As a theologian, I see participants do more than just produce and engage in a ritual event; I see, that is I actively read into their practices, a quest for God. This is something that philosophers, anthropologists, sociologists and scholars in digital media studies do not see. Particular theological knowledge arises at the intersection of the different disciplinary perspectives which comes together around this ritual event as they pool their rational resources; it emerges out of (theoretical or) disciplinary triangulation. ${ }^{8}$

With respect to the other three metatheoretical issues: I understand Osmer's thoughts regarding the nature of praxis, and theory's relationship to it, as an issue which overlaps with my account of the ontological perspective (cf. the four layers of ritual practices) and with the epistemological position (embodied knowledge combined with theoretical interpretation) that I have taken in this research, as described above. ${ }^{9}$

With regards to the sources of justification used in this research, I seem mostly to have drawn upon the sources of experience and reason; Scripture has played a particular role in the four side lights in which I creatively reflected on the preceding treatises.

7 Osmer, Practical Theology, 172.

8 Osmer, Practical Theology, 172.

9 Osmer, "Practical Theology", 4. 
Tradition did not take on a particularly prominent role, although it perhaps played a more-general part in my description of changes in Christian ritual repertoire describing the transfer and transformation of older, more 'traditional' forms, and, more particularly, in my linking of the passion to ecclesial practices of Holy Week passion performance during the fourth century CE, and of processional practices in The Passion to the longer ecclesial tradition of processions inside and outside of church buildings.

The theological rationale that justifies my approach in this study is founded on two convictions. The first is a sacramental understanding of ritual that has characterised my theology practice over the past twenty years: the conviction that God (whether or not called by that name) and faith are always mediated and welcomed in our physical existence through embodied practices. This is why my approach and Kearney's anatheistic theory combine well together: the sacramental imagination is an important part of Kearney's work. The second conviction that shapes my theological rationale, and which I have already discussed in the Prologue, is my theologically informed interest in people and practices that are looked down on by other people who know all too well how God wants things to be, and what is theologically right. These are pre-eminently the people and practices to pay attention to.

\section{An Ethno-Case Study}

This project was set up as an ethnographic study; a research method that I had used before. In 2011, I published a liturgical-musical ethnography on the sound of worship in two Christian churches in the city of Amsterdam: a Surinamese and a Ghanaian congregation. The 'ethnos' that I joined for nine months in both cases was, compared to the passion project, relatively well demarcated and straightforward to research: the respective congregations consisted of a relatively stable group of some 60 and 200 people, who gathered for worship in the same place every week. Those who performed the worship - the ministers, members of church choirs, and other musicians - were the same people almost every week, so after nine months of fieldwork I had become acquainted with almost everyone who regularly worshiped in these congregations.

In my fieldwork on The Passion, I was soon confronted with 'next level complexities', as this case significantly differed from the previous cases that I had investigated. How to describe 'the ethnos' here? The actors and parties involved in this project were hugely diverse and they were located in so many different places. How to combine ethnography amongst people in real life with digital/virtual/online/cyber ethnography, how to distinguish between the offline audience and the online audience, or even to make such a distinction in the first place? How to deal with the extreme fluidity of this practice, with an audience that differed from one year to another and only got together for 90 minutes? And how to deal with the producers and broadcasters who 
spent a couple of months intensively working on each edition as well as with the other media that were increasingly involved? Similar questions arose in relation to other concepts relating to ethnographic fieldwork. How to describe 'the field'? How to enter the field when players in this field were not equally easy to approach? What elements should be included within the domain of the research? How to handle the enormous amount of (big) data? And would I ever reach a level of saturation? As The Passion grew bigger after the first edition, I realised that performing a full-fledged ethnography on my own would be undoable: I had to accept that the case would inevitably be fragmented in nature.

A research strategy based on case studies seemed more appropriate for the size and complexity of The Passion since it offers a rigorous method that is suited to, among other things, research that is exploratory in nature. ${ }^{10}$ Robert Yin, who wrote one of the standard works on the subject, describes the case study as "an empirical inquiry that investigates a contemporary phenomenon within its real-life context, especially when the boundaries between phenomenon and context are not clearly evident".11 This definition seemed to fit the type of case study that I was undertaking with The Passion, the fluidity of the phenomenon and the involvement of the media, in particular, made it look like the case was everywhere. In an article that discusses the challenges of a single case study in practical theological research, Eileen Campbell-Reid argues, in line with Flyvbjerg's argument which I discussed in the Prologue of this book, that good case studies are able to provide knowledge. She restates the value of case studies for practical theology as follows: "A search in the scholarship of practical theology for universal, predictive theories is in vain. The most valuable knowledge is the contextdependent knowledge found on concrete cases.". ${ }^{12}$ In Miller-McLemore's handbook on practical theology, Daniel Schipani takes a definition from the field of pastoral care. He writes that the case study "can be defined as an organized and systematic way of studying and reporting various aspects of a person, family, group, or situation utilising a structured outline of subjects and questions (Asquith 1990: 123-126). In practical theology, the case study method can be used for different purposes, such as "critical and constructive reflection on ecclesial and ministry practice; study, analysis, and evaluation of different forms of faith experience, formation, and transformation; and theory building as well as application or demonstration of theory. In each of those instances, the goal is fundamentally the same, namely, to provide further insight by focusing intensely on a particular case that is approachable from diverse perspectives". ${ }^{13}$

\footnotetext{
10 Robert Yin, Case Study Research. Design and Methods (3rd ed.) (London: Sage, 2003), 1.

11 Yin, Case Study Research, 13.

12 Eileen Campbell-Reed, "The power and danger of a single case study in practical theological research", in Conundrums, eds. Mercer and Miller- McLemore, 33-59, at 47.

13 Daniel Schipani, "Case Study Method", in The Wiley-Blackwell Companion, ed. MillerMcLemore, 91-101, 91.
} 
Offering a variety of different perspectives on different aspects of one particular case was what I aimed for with my case study on The Passion, however, I did not utilise a structured outline of topics and questions. Quite the reverse, in fact, the influence of the field itself on the choice of topics remained strong. The aspects that I chose to investigate, particularly those discussed in Part 2 of this book, arose from the field. I began with a rather open research question and, in order to get towards an answer, kept using ethnographic research methods, and kept listening to the field, focusing in on what struck me as interesting. I certainly did not work with a list of topics and questions.

The research method eventually took the shape of an 'ethno-case study'; a hybrid form of research, combining case study research and ethnographic methods. The term for this type of study was coined by scholar in educational studies Marie ParkerJenkins, who describes it as "an inquiry concerning people, which employs techniques associated with long-term and intensive ethnography, but which is limited in terms of scope and time spent in the field". ${ }^{14}$ Parker-Jenkins argues that the main difference between contemporary ethnography and case study research is the degree of immersion in the context and/or data. ${ }^{15}$ According to her, the advantage of employing the term ethno-case study is that it "sets boundaries for the researcher; acknowledges that it is a study located within a richer, wider context; conveys the sense of conducting an inquiry with people, employing ethnographic techniques; suggests limited research time and immersion in the context and/or data; gives the reader some level of expectation in terms of the project results and claims". ${ }^{16}$ In this type of research, it is legitimate to focus investigation on a limited number of themes, and I did this in Part 2, in particular, as I focussed on the spatial, ludic, reflexive and public-theological aspects of The Passion, using a selection of different disciplinary perspectives. ${ }^{17}$ In each of these chapters I have described how the different topics arose from within the field. In hindsight, I should acknowledge that a number of those topics are related to public aspects of the ritual; it may be the case that my attention was particularly drawn to the public character of the event. Possibly, this was the result of public discourse on religion and secularity in which those with a negative view on religion hold the opinion that religion belongs (or should move) to the private domain. Some have claimed for a long time that the public domain should be 'neutral', i.e. void of religious practices and expressions. It has struck me that, notwithstanding, or perhaps even because of this

\footnotetext{
14 Parker-Jenkins, "Problematising ethnography and case study", 24.

15 Parker-Jenkins, "Problematising ethnography and case study", 23.

16 Parker-Jenkins, "Problematising ethnography and case study", 25.

17 It is true that numerous other perspectives were possible and would have yielded other insights, e.g. perspectives focussing on popular culture, power, mediatisation, or entrepreneurship/business.
} 
discourse, The Passion was staged in the public sphere and was not banned from it, but was able to grow into a large media over the course of eight years.

At the end of her discussion of the power and dangers of a single case study, Eileen Campbell-Reid offers four brief guidelines that, in my view, are also relevant to ethnocase studies. She writes, first of all, that practical theologians should not refrain from taking the risk of using single case studies as they have the potential to yield practical wisdom, but that researchers should also make sure that they moderate dangers such as personal bias, overgeneralisation, and lack of attention to power dynamics within their research, things which they should also be careful of when considering the researcher's own role in the situation. I have tried to mitigate these dangers by offering an account of my methodological choices, including possible biases, here, by staying as close as possible to the cases themselves when drawing conclusions throughout the book, and by being attentive to power dynamics during fieldwork (particularly among the organising bodies, since there are many conflicts of interests in the world of producers and broadcasters). I have kept notes on my own role as a researcher in the field and as a theologian in the public domain, seeking to constructively reflect on the power dynamics relating to my own role, and I have included positionality statements in the prologue, here and in the final chapter of this book for the sake of transparency.

Secondly, Campbell-Reed suggests that the relational and participatory character of practical wisdom should be reflected in case studies. This is easier said than done in a case study on an event in the public sphere, which is organised by producers and broadcasters: they are often very busy and are not necessarily interested in a quest for God, for example, nor are millions of participants always equally interested in research. A 'group' that has continuously shown interest in the research consists of clergy and church people. They have seen The Passion pop up in the public sphere and, from the first edition onwards, have asked me to help reflect on what the changing role of religion and rituality in the public sphere could mean for the churches. I have also learned from their questions and perspectives and I have often brought the results of this learning back into the research. Church people have been given a place, though a modest one, in the construction of this study, especially in the last side light: the letter.

A third guideline regards the situating of case studies in their historical, social, political and theological contexts. The structure of this monograph enabled me to address these contexts in a natural manner; the subsequent chapters all discuss various aspects of context-setting.

The last guideline that Campbell-Reed mentions relates to the development of bicultural expertise, which, in the context of this particular ethno-case study, I take to mean that the researcher should avoid writing a narrative that suffers from academic specialisation and which, as a result, becomes inaccessible to a wider audience. Instead, the writer should make sure that different people (academics as well as professionals in Christian ministry) are able to read and understand the study. As Bent 
Flyvbjerg rightly states: "The goal is not to make the case study be all things to all people. The goal is to allow the study to be different things to different people". ${ }^{18}$ For this reason, I had two colleagues - a biblical scholar with expertise in systematic theology and a colleague in the ministry - read the manuscript critically with an eye to its usefulness both for academics outside the field of practical theology and for theological practitioners; they both made invaluable comments that have immensely improved the comprehensibility of the manuscript for a diverse audience.

\section{Methodological Account of Empirical Research}

The empirical data discussed and analysed in this monograph are on the result of fieldwork undertaken on The Passion between April 2011 and October 2019. Data and methodology were both subject to processes of triangulation and, as a result, several different research sources and data collection methods can be distinguished through the course of my text.

\section{Participant Observation in the Square and on TV}

I performed participant observation at the squares where The Passion was staged in Gouda in 2011 (with colleague and co-author Marcel Barnard), Rotterdam in 2012 (with two academic colleagues; I also attended the press presentation of the event in Rotterdam a few weeks before the performance), Groningen in 2014 (with colleague and co-author Marten van der Meulen), Enschede in 2015 (with Marten van der Meulen and our research masters student Anita Zijdemans), New Orleans 2016 and Amersfoort (with a colleague in ministry) in 2016. In 2014, I left the square in Groningen after a spending some time there, in order to be able to join students and colleagues at the PThU premises in watching The Passion on TV. In 2013, 2017 and 2019, I watched The Passion on TV at home. In 2018, I watched it at the premises of broadcasting company EO, together with three participants from previous editions: Singer Do (who played the role of Mary in 2011), Charly Luske (Judas in 2012), Howard Komproe (Pontius Pilate in 2016) and some ten EO-employees, prior to the talk show Passiontalk which was broadcast live immediately after the 2018 edition and to which I was invited as a guest.

\section{Semi-Structured Interviews and Informal Conversations}

Between 2011 and 2019, we conducted around thirty in-depth semi-structured interviews with a variety of people (producers, performers, cross-bearers, residents of the local municipality, press spokesmen for various bodies, churches); in addition to these

18 Bent Flyvbjerg, "Five Misunderstandings", 223. 


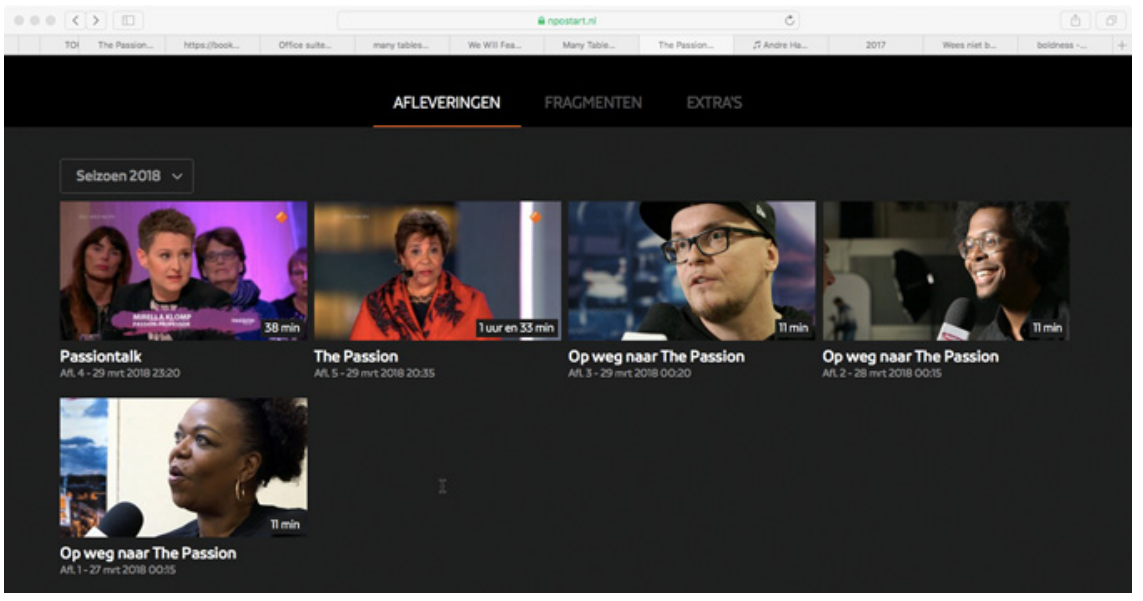

FIGURE 18 The online time-shifted viewing screen for The Passion in 2018 presented a number of video clips and broadcasts. From left to right: the talk show Passiontalk (featuring me), the 2018 edition of The Passion, and three brief digital interviews with performers which were launched via socials in the days prior to the performance SCREENSHOT FROM Www.npostart.nl

one-hour interviews, from 2013 onwards, around ten shorter interviews a year were held with various people in the field.

Between January and May 2015 more-extensive fieldwork was performed (including participatory research), mainly by our student Anita Zijdemans. This research was done in a number of different ways, both with regards to methodology and data. During the preparations for The Passion in 2015, Zijdemans conducted four semistructured interviews with relevant people from the broadcasting companies EO and $\mathrm{RKK}$ - among them the press spokesman and the chief editors - we well as three informal conversations with the photographer for the promotional photoshoots and two singers. The producer was not available for interviews during that period. Additionally, Zijdemans had fifteen to twenty informal conversations with managers from the broadcasting companies, creative and communications people, and other people from behind the scenes. She attended a number of meetings in which decisions regarding the event were made, as well as an evaluation meeting after the event. Her attendance at these meetings was in an observatory role only, which means that the taking of fieldnotes was the most important task. This observatory role demonstrates the limits that were explicitly and implicitly set for the researcher: entering the field was not easy (see below). Part of the preparation for The Passion was to practice the procession with the large illuminated cross that is part of the performance. Zijdemans attended this practice for the procession in Enschede, together with the project manager, the chief editors from RKK and EO, and the executive producer. This enabled us to ask the 
people participating in the procession about their motivations, but also provided an opportunity to talk to the organisers in a more informal setting. We combined interviews and observations at meetings with participant observation at the event itself in Enschede, where we also conducted around seventy short interviews about the event with people in the audience on the basis of a three-question survey.

\section{Digital Documents}

The broadcasters sent us the so-called 'line-ups' (detailed outlines of the broadcast with scenes, texts, songs, instructions on 'instarts', autocue and camera work) from all nine editions of The Passion. These were mainly used as a secondary source, to doublecheck our observations or information on the performance, although they were also used as a primary source for two quotations in Chapter 3 (taken from the transcription of the pre-interview with the firemen in Enschede). I received an unpublished PDF-document and a number of emails with information on viewing figures from the market researchers for the broadcasting company KRO-NRCV.

\section{Online Data Sources}

A number of online data sources were used more extensively. First and foremost, www .npostart.nl where, after each edition of The Passion, I (re)watched the TV show at least once, often twice. In order to describe and analyse particular topics that were addressed in the subsequent chapters of this book, I used this source in order to watch specific parts of the broadcasts of various editions a number of times: the procession in 2014 and 2015 (Chapter 3), the parts showing the audience when they laughed and the jokes made by the organiser in the 2015 edition (Chapter 5 ), the scenes in several editions depicting the arrest and conviction of Jesus (Chapter 6), and the resurrection scenes from all editions (Chapter 7 ).

A second online data source that I used, mainly for the analysis with Marten van der Meulen of the data reported on in Chapter 5 , was live.thepassion.nl: the 'second screen application' that, from 2014 onwards, enabled people to participate in the procession online and to share their personal motivations. From the broadcasters, I received Excel files containing all of the 'walk-along-motivations' from the 2014 and 2015 editions, and I used these as a secondary source (e.g. to look up keywords), supporting the research on the online processions (which were elaborated on in Chapters 3 and 5).

A third online data source was Twitter. Marten van der Meulen and I used this source in 2015 in particular, when we collected a set of data consisting of 3,500 tweets with "hashtags" \#thepassion and \#tp15, in order to gain insight into how the public 'plays' The Passion in social media. The organisation introduced these "official" hashtags via their own Twitter-account, @thepassion, in order to create a platform and encourage discussion via tweets. According to the organizers of The Passion, approximately 6o,ooo tweets on The Passion were sent. We used the online tool Twitter Archiv- 
er to aggregate all tweets that were sent for several hours before, during, and after the event, which contained the relevant hashtags or tagged the relevant Twitter users. We excluded all retweets, which made up a large volume of the total number of tweets but added little to the analysis. All tweets were saved in the document 'Passion-Archiver excel-sheet' and analysed, particularly with regard to ludic aspects in the form of jokes, that helped to understand The Passion as a ludic practice.

\section{Entering and Exiting the Field}

A final word on the process of entering and exiting the field. Considering the fact that accessibility is one of the key reasons for the success of The Passion (everyone can join the event on the square for free, and likewise everyone with a TV or access to the internet can watch the broadcast), entering the field was relatively easy. When it came to contact with different producers and broadcasters, the dynamics varied.

Production company Eye2Eye Media was a very small company where people did not always have time to talk. In 2015, the founder and director of the company welcomed me at his office and we spoke for an hour. In 2016, he also allowed me to join his team in New Orleans, where I carried out participatory observation on the procession and followed the procession production team.

From my first phone call to the broadcaster on behalf of the Roman-Catholic church, RKK, in 2011, onwards, I was warmly welcomed into the broadcaster's office by two people who would always make time for interviews, shared information, and showed me sneak-previews of clips from the upcoming editions of The Passion. The fact that RKK was a small broadcaster was very helpful: it was easy to build a relationship of mutual trust and our communication had a spirit of openness. After RKK merged to become part of KRO-NCRV, more people were added to The Passion-team of this broadcaster, but the open character of the initial contact was extended as I was introduced to these new colleagues.

Building relationships with people at the broadcaster EO was a little more difficult since the organisation as such is larger and more hierarchically structured, and there was a higher rate of staff turnover in the production-team. This meant that there was less continuity compared to the other organising parties, and, although the management after an official meeting, allowed us to do research at EO, people who were on the job were not always aware of this. A number of them were reluctant to share information with us, because they did not know whether they were actually allowed to do so. It took more time to build a relationship of trust, and in the end, the best relationship we managed to build was with employees from the communication department (which may seem obvious, as the main task of this department is to communicate and send out information).

In meetings of the general production team (with members from all three organising parties), there was always a slight suspicion towards the researchers, possibly 
because members did not understand the relationship of the researchers with colleagues from the other parties, and perhaps also because of the dynamics and conflicting interests that were present among the team itself. Informal conversations with individuals afterwards often helped individual pieces of information to fall into place. It should be noted that ca. $50 \%$ of the resources for the production and broadcasting companies are provided from KRO-NCRV sources, ca. $25 \%$ from EO sources and ca. $25 \%$ from Eye2Eye sources.

Exiting the field went gradually, with decreased involvement in ethnographic research in the last two years. After completion of the manuscript and before submitting it to the publisher for production, I sent it to the production company and the broadcasting companies to give them the opportunity to check the text for factual inaccuracies and, if desired, to respond to it. None of them indicated any errors. 


\section{Tables}

The data in this appendix are taken from the national survey GIN from 2015 (results published in 2016), which uses the LIss panel: a web survey, completed by an internet panel. The total sample included 2,197 respondents (response rate: $74 \%$ ). All analyses were weighted according to the urban status of the place of residence, age and education. The (small) group of 57 supporters of non-Christian religions has not been considered, which brings the number of respondents to a total of 2,140.

TABLE 1 Have you ever watched the TV-broadcast of The Passion (or attended the event itself)?

\begin{tabular}{lc}
\hline & $\%$ \\
\hline More than once & 27 \\
Only once & 22 \\
Never & 49 \\
Don't know & 2 \\
Rating (1-10) by those who watched at least once & 7.0 \\
\hline
\end{tabular}

TABLE 2 How do you feel about the way The Passion is organised and depicted? (for respondents who have watched at least once)

\begin{tabular}{lcccccc}
\hline & $\begin{array}{c}\text { Strongly } \\
\text { disagre }\end{array}$ & Disagree & $\begin{array}{c}\text { Neither } \\
\text { agree nor } \\
\text { disagree }\end{array}$ & Agree & $\begin{array}{c}\text { Strongly } \\
\text { agree }\end{array}$ & $\begin{array}{c}\text { Don't } \\
\text { know }\end{array}$ \\
\hline Engaging & 6 & 9 & 22 & 37 & 23 & 3 \\
Kitschy & 14 & 34 & 26 & 15 & 6 & 5 \\
$\begin{array}{l}\text { Strengthens faith } \\
\text { Arouses curiosity about }\end{array}$ & 30 & 28 & 21 & 11 & 5 & 5 \\
Chr. faith & 29 & 29 & 21 & 12 & 4 & 5 \\
\end{tabular}


TABLE 3 Frequency of viewing and rating classified by viewers' characteristics

\begin{tabular}{|c|c|c|c|c|}
\hline & $\begin{array}{c}\text { More } \\
\text { than } \\
\text { once }\end{array}$ & $\begin{array}{l}\text { Only } \\
\text { once }\end{array}$ & Never & $\begin{array}{c}\text { Rating } \\
(1-10) \text { by } \\
\text { viewers }\end{array}$ \\
\hline Man & 20 & 21 & 57 & 6,8 \\
\hline Woman & 33 & 23 & 42 & 7,1 \\
\hline Very urban & 22 & 26 & 49 & 6,8 \\
\hline Predominantly urban & 27 & 21 & $5^{1}$ & 6,9 \\
\hline Intermediately urban & 30 & 18 & $5^{\circ}$ & 7,1 \\
\hline Predominantly rural & 29 & 23 & 46 & 7,1 \\
\hline Very rural & 29 & 20 & 47 & 7,1 \\
\hline Elementary education & 21 & 19 & 56 & 7,1 \\
\hline Preparatory secondary vocational education & 30 & 23 & 45 & 7,1 \\
\hline $\begin{array}{l}\text { Higher general secondary / } \\
\text { pre-university education }\end{array}$ & 25 & 26 & 47 & 6,7 \\
\hline Intermediate vocational education & 29 & 20 & 48 & 7,2 \\
\hline Higher professional education & 27 & 24 & 48 & 6,8 \\
\hline Academic education & 19 & 22 & 59 & 6,4 \\
\hline 15-24 age-group & 21 & 18 & 56 & 7,0 \\
\hline 25-34 age-group & 15 & 21 & 60 & 6,8 \\
\hline $35-44$ age-group & 25 & 22 & 51 & 7,3 \\
\hline $45-54$ age-group & 28 & 24 & 48 & 7,1 \\
\hline $55^{-64}$ age-group & 33 & 22 & 43 & 6,9 \\
\hline $65^{+}$age-group & 32 & 23 & 44 & 6,8 \\
\hline All & 27 & 22 & 49 & 7,0 \\
\hline
\end{tabular}


TABLE 4 Assessment classified by social-structural characteristics (for viewers who have watched at least once)

Strongly agrees or agrees:

\begin{tabular}{|c|c|c|c|c|}
\hline & Engaging & Kitschy & $\begin{array}{l}\text { Strengthens } \\
\text { faith }\end{array}$ & $\begin{array}{l}\text { Arouses } \\
\text { curiosity }\end{array}$ \\
\hline $\operatorname{Man}(41 \%)$ & 53 & 26 & 12 & 12 \\
\hline Woman $(56 \%)$ & 64 & 19 & 17 & 19 \\
\hline Very $\operatorname{urban}(48 \%)$ & $5^{2}$ & 26 & 15 & 15 \\
\hline Pre-dominantly urban $(48 \%)$ & $5^{8}$ & 20 & 14 & 14 \\
\hline Intermediately urban (48\%) & 65 & 23 & 15 & 15 \\
\hline Predominantly rural $(52 \%)$ & 61 & 18 & 17 & 17 \\
\hline Very rural $(49 \%)$ & 64 & 25 & 16 & 16 \\
\hline Elementary education (40\%) & 56 & 22 & 24 & 24 \\
\hline $\begin{array}{l}\text { Preparatory secondary vocational } \\
\text { education }(53 \%)\end{array}$ & 57 & 18 & 18 & 14 \\
\hline $\begin{array}{l}\text { Higher general secondary / } \\
\text { pre-university education }(51 \%)\end{array}$ & 54 & 26 & 8 & 16 \\
\hline Intermediate vocational education $(49 \%)$ & 66 & 15 & 16 & 18 \\
\hline Higher professional education $(51 \%)$ & 62 & 26 & 12 & 12 \\
\hline Academic education $(41 \%)$ & 49 & 42 & 15 & 14 \\
\hline $15-24$ age-group (39\%) & 61 & 25 & 18 & 28 \\
\hline $25-34$ age-group $(36 \%)$ & 61 & 26 & 18 & 30 \\
\hline $35-44$ age-group $(47 \%)$ & 69 & 19 & 12 & 18 \\
\hline $45-54$ age-group $\left(5^{2} \%\right)$ & 62 & 18 & 13 & 9 \\
\hline $55^{-64}$ age-group $(55 \%)$ & $6 o$ & 20 & 16 & 12 \\
\hline $65^{+}$age-group $(55 \%)$ & $5^{2}$ & 24 & 17 & 14 \\
\hline All (49\%) & 60 & 21 & 16 & 16 \\
\hline
\end{tabular}


TABLE 5 Frequency of viewing and assessment classified by church background/affiliation

\begin{tabular}{|c|c|c|c|c|c|c|c|}
\hline & \multicolumn{2}{|c|}{$\begin{array}{l}\text { Frequency } \\
\text { of viewing: }\end{array}$} & \multirow{2}{*}{$\begin{array}{c}\text { Viewers' } \\
\text { rating } \\
(1-10)\end{array}$} & \multirow[b]{2}{*}{ Engaging } & \multicolumn{2}{|c|}{ Viewers' assessment: } & \multirow[b]{2}{*}{$\begin{array}{l}\text { Arouses } \\
\text { curiosity }\end{array}$} \\
\hline & $\begin{array}{l}\text { More } \\
\text { than } \\
\text { once }\end{array}$ & $\begin{array}{l}\text { Only } \\
\text { once }\end{array}$ & & & Kitschy & $\begin{array}{l}\text { Strengthens } \\
\text { faith }\end{array}$ & \\
\hline $\begin{array}{l}\text { No religious } \\
\text { upbringing }\end{array}$ & 17 & 19 & 6,7 & 49 & 22 & 22 & 12 \\
\hline R-C upbringing & 30 & 22 & 7,1 & 65 & 19 & 19 & 12 \\
\hline $\begin{array}{l}\text { Netherlands } \\
\text { Reformed } \\
\text { upbringing }\end{array}$ & 36 & 24 & 7,0 & 63 & 25 & 25 & 16 \\
\hline $\begin{array}{l}\text { Reformed } \\
\text { Churches } \\
\text { upbringing }\end{array}$ & 47 & 27 & 7,0 & 64 & 20 & 20 & 19 \\
\hline $\begin{array}{l}\text { Currently not a } \\
\text { church member }\end{array}$ & 21 & 21 & 6,9 & 54 & 23 & 8 & 11 \\
\hline Currently R-C & 42 & 25 & 7,2 & 71 & 18 & 23 & 18 \\
\hline Currently PCN & 46 & 26 & 7,2 & 72 & 19 & 31 & 24 \\
\hline $\begin{array}{l}\text { Currently R-C } \\
\text { member, but } \\
\text { not a frequent } \\
\text { churchgoer }\end{array}$ & 39 & 26 & 7,2 & 72 & 19 & 17 & 13 \\
\hline $\begin{array}{l}\text { Currently R-C } \\
\text { member and regular } \\
\text { churchgoer }\end{array}$ & 46 & 24 & 7,1 & 69 & 18 & 32 & 26 \\
\hline $\begin{array}{l}\text { Currently PCN } \\
\text { member, but } \\
\text { not a frequent } \\
\text { churchgoer }\end{array}$ & 35 & 28 & 7,2 & 68 & 18 & 22 & 19 \\
\hline $\begin{array}{l}\text { Currently PCN } \\
\text { member and regular } \\
\text { churchgoer }\end{array}$ & 51 & 25 & 7,2 & 74 & 20 & 34 & 26 \\
\hline All & 27 & 22 & 7,0 & 60 & 21 & 16 & 16 \\
\hline
\end{tabular}


TABLE 6 Frequency of viewing and assessment classified by the number of situations in which people consider religion to have an important role $(\%$ very or rather important)

\begin{tabular}{|c|c|c|c|c|c|c|c|}
\hline \multirow[t]{2}{*}{$\begin{array}{l}\text { Number of } \\
\text { situations: }\end{array}$} & \multicolumn{2}{|c|}{$\begin{array}{l}\text { Frequency } \\
\text { of viewing: }\end{array}$} & \multirow{2}{*}{$\begin{array}{c}\text { Viewers' } \\
\text { rating } \\
(1-10)\end{array}$} & \multirow[b]{2}{*}{ Engaging } & \multicolumn{2}{|c|}{ Viewers' assessment: } & \multirow[b]{2}{*}{$\begin{array}{l}\text { Arouses } \\
\text { curiosity }\end{array}$} \\
\hline & $\begin{array}{c}\text { More } \\
\text { than } \\
\text { once }\end{array}$ & $\begin{array}{l}\text { Only } \\
\text { once }\end{array}$ & & & Kitschy & $\begin{array}{l}\text { Strengthens } \\
\text { faith }\end{array}$ & \\
\hline None & 13 & 20 & 6,5 & 45 & 27 & 2 & 4 \\
\hline $1 / 2$ & 21 & 22 & 6,6 & 47 & 27 & 3 & 4 \\
\hline $3 / 4$ & 22 & 25 & 6,9 & $5^{2}$ & 22 & 9 & 8 \\
\hline $5 / 6$ & 31 & 24 & 7,1 & 68 & 12 & 7 & 9 \\
\hline $7 / 8$ & 34 & 26 & 7,2 & 63 & 18 & 21 & 19 \\
\hline $9 / 10$ & 39 & 22 & 7,3 & 70 & 18 & 26 & 30 \\
\hline $11 / 12$ & 46 & 18 & 7,3 & 73 & 24 & 36 & 31 \\
\hline All & 27 & 22 & 7,0 & 60 & 21 & 16 & 16 \\
\hline
\end{tabular}


TABLE 7 Frequency of viewing and assessment classified by the number of situations in which they consider religion to have an important role (\% very or rather important), in detail

\begin{tabular}{|c|c|c|c|c|c|c|c|}
\hline \multirow{3}{*}{$\begin{array}{l}\text { Number of } \\
\text { situations: }\end{array}$} & \multicolumn{2}{|c|}{$\begin{array}{l}\text { Frequency } \\
\text { of viewing: }\end{array}$} & \multirow{3}{*}{$\begin{array}{c}\text { Viewers' } \\
\text { rating } \\
(1-10)\end{array}$} & \multirow{3}{*}{ Engaging } & \multicolumn{3}{|c|}{ Viewers' assessment: } \\
\hline & & & & & Kitschy & Strengthens & Arouses \\
\hline & $\begin{array}{l}\text { More } \\
\text { than } \\
\text { once }\end{array}$ & $\begin{array}{l}\text { Only } \\
\text { once }\end{array}$ & & & & faith & curiosity \\
\hline
\end{tabular}

At/for:

Collective identity

- Dutch identity

- European identity

$\begin{array}{lll}39 & 21 & 7,2\end{array}$

70

22

28

29

Ethics

$\begin{array}{lll}37 & 19 & 7,2\end{array}$

69

21

30

30

- Living well together

$\begin{array}{lll}37 & 22 & 7,2\end{array}$

68

21

25

25

- Retention of norms

$\begin{array}{lll}36 & 22 & 7,2\end{array}$

67

21

21

21

and values

Social criticism

- Societal abuses

- Being a nuisance to

$\begin{array}{llll}38 & 21 & 7,2 & 67 \\ 36 & 20 & 7,0\end{array}$

67

21

25

those in power

- The interest of

$42 \quad 20 \quad 7,2$

62

25

25

sobriety

Commemorations

- Remembrances

- Disasters

$\begin{array}{lll}36 & 24 & 7,2\end{array}$

67

22

25

- National festivities

$\begin{array}{lll}36 & 23 & 7,2\end{array}$

66

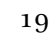

23

21

$\begin{array}{lll}36 & 23 & 7,2\end{array}$

71

20

Family circle

- Life events

$\begin{array}{lll}35 & 23 & 7,2\end{array}$

68

18

28

- Raising children

$\begin{array}{lll}38 & 23 & 7,2\end{array}$

67

20

22

21

24

22

All

$\begin{array}{lll}27 & 22 & 7,0\end{array}$

60

21

16

16 
TABLE 8 Have you ever watched the TV-broadcast of The Passion or attended the event?

\begin{tabular}{lccc}
\hline & $\begin{array}{c}\text { More than } \\
\text { once }\end{array}$ & Only once & $\begin{array}{c}\text { Viewer's rating } \\
(\mathbf{1 - 1 0})\end{array}$ \\
\hline Neither religious, nor spiritual & 17 & 21 & 6,7 \\
Religious, but not spiritual & $\mathbf{3 7}$ & 22 & 7,3 \\
Not religious, but spiritual & 23 & 20 & 6,9 \\
Religious as well as spiritual & $\mathbf{4 0}$ & 24 & 7,1 \\
Total & 27 & 22 & 7,0 \\
\hline
\end{tabular}

TABLE 9 How do you feel about the way The Passion is organised and depicted?

\begin{tabular}{lcccc}
\hline & Engaging & Kitschy & $\begin{array}{c}\text { Strengthens } \\
\text { faith }\end{array}$ & $\begin{array}{c}\text { Arouses } \\
\text { curiosity }\end{array}$ \\
\hline Neither religious, nor spiritual & 50 & 26 & 2 & 6 \\
Religious, but not spiritual & $\mathbf{7 1}$ & 20 & 24 & 19 \\
Not religious, but spiritual & 51 & 19 & 6 & 9 \\
Religious as well as spiritual & 67 & 19 & $\mathbf{2 9}$ & $\mathbf{2 9}$ \\
Total & 60 & $\mathbf{2 2}$ & 16 & 16 \\
\hline
\end{tabular}


TABLE 10 Frequency of viewing and assessment classified by spiritual interest and practices

\begin{tabular}{|c|c|c|c|c|c|c|c|}
\hline & \multicolumn{2}{|c|}{$\begin{array}{l}\text { Frequency } \\
\text { of viewing: }\end{array}$} & \multirow{2}{*}{$\begin{array}{c}\text { Viewers' } \\
\text { rating } \\
(1-10)\end{array}$} & \multirow{2}{*}{ Engaging } & \multicolumn{2}{|c|}{ Viewers' assessment: } & \multirow[b]{2}{*}{$\begin{array}{l}\text { Arouses } \\
\text { curiosity }\end{array}$} \\
\hline & $\begin{array}{l}\text { More } \\
\text { than } \\
\text { once }\end{array}$ & $\begin{array}{l}\text { Only } \\
\text { once }\end{array}$ & & & Kitschy & $\begin{array}{l}\text { Strengthens } \\
\text { faith }\end{array}$ & \\
\hline $\begin{array}{l}\text { Occasionally visits } \\
\text { place to dwell } \\
\text { on things; }\end{array}$ & 36 & 25 & 7,1 & 68 & 22 & 23 & 23 \\
\hline $\begin{array}{l}\text { Participation in } \\
\text { course, contemplative } \\
\text { weekend etc. aimed at } \\
\text { spirituality/meaning } \\
\text { of life; }\end{array}$ & 36 & 25 & 6,8 & 61 & 23 & 22 & 19 \\
\hline $\begin{array}{l}\text { Occasionally lights } \\
\text { a candle for } \\
\text { something/someone; }\end{array}$ & 35 & 24 & 7,1 & 65 & 19 & 18 & 18 \\
\hline $\begin{array}{l}\text { Need to ponder } \\
\text { on the meaning } \\
\text { of life; }\end{array}$ & 35 & 24 & 7,0 & 64 & 23 & 23 & 22 \\
\hline $\begin{array}{l}\text { Visited or assisted } \\
\text { at memorial site; }\end{array}$ & 34 & 23 & 7,1 & 64 & 13 & 21 & 20 \\
\hline $\begin{array}{l}\text { Has a 'sacred' space } \\
\text { at home, like } \\
\text { altar or place } \\
\text { for meditation; }\end{array}$ & 34 & 19 & 7,1 & 65 & 17 & 33 & 24 \\
\hline $\begin{array}{l}\text { (Has) practiced } \\
\text { yoga over the } \\
\text { last years; }\end{array}$ & 28 & 25 & 6,8 & $5^{6}$ & 22 & 12 & 14 \\
\hline $\begin{array}{l}\text { Participated in a } \\
\text { silent procession; }\end{array}$ & 28 & 24 & 7,0 & 59 & 16 & 18 & 15 \\
\hline $\begin{array}{l}\text { (Has) practiced } \\
\text { meditation over } \\
\text { the last years; }\end{array}$ & 27 & 24 & 6,7 & 54 & 24 & 18 & 18 \\
\hline $\begin{array}{l}\text { Participated in } \\
\text { pilgrimage (e.g. to } \\
\text { Sant. de Compostela) }\end{array}$ & 24 & 22 & 6,3 & 60 & 36 & 16 & 12 \\
\hline All & 27 & 22 & 7,0 & $6 o$ & 21 & 16 & 16 \\
\hline
\end{tabular}


TABLE 11 Frequency of viewing and assessment classified by situations in which respondents feel united with other Dutch people

\begin{tabular}{|c|c|c|c|c|c|c|c|}
\hline & \multicolumn{2}{|c|}{$\begin{array}{l}\text { Frequency } \\
\text { of viewing: }\end{array}$} & \multirow{2}{*}{$\begin{array}{c}\text { Viewers' } \\
\text { rating } \\
(1-10)\end{array}$} & \multirow[b]{2}{*}{ Engaging } & \multicolumn{2}{|c|}{ Viewers' assessment: } & \multirow[b]{2}{*}{$\begin{array}{l}\text { Arouses } \\
\text { curiosity }\end{array}$} \\
\hline & $\begin{array}{c}\text { More } \\
\text { than } \\
\text { once }\end{array}$ & $\begin{array}{l}\text { Only } \\
\text { once }\end{array}$ & & & Kitschy & $\begin{array}{l}\text { Strengthens } \\
\text { faith }\end{array}$ & \\
\hline Sports competitions; & 29 & 23 & 7,1 & 61 & 21 & 16 & 15 \\
\hline $\begin{array}{l}\text { Death of a famous } \\
\text { Dutchman; }\end{array}$ & 35 & 24 & 7,1 & 65 & 18 & 18 & 16 \\
\hline Koningsdag; & 33 & 24 & 7,2 & 66 & 20 & 18 & 18 \\
\hline $\begin{array}{l}\text { Commemoration } \\
\text { WW II; }\end{array}$ & 30 & 23 & 7,0 & 62 & 21 & 16 & 16 \\
\hline $\begin{array}{l}\text { Parliamentary } \\
\text { elections; }\end{array}$ & 28 & 24 & 6,9 & 60 & 25 & 18 & 17 \\
\hline A protest meeting; & 32 & 21 & 7,1 & 63 & 20 & 22 & 20 \\
\hline $\begin{array}{l}\text { Commemoration } \\
\text { of a disaster; }\end{array}$ & 32 & 22 & 7,1 & 63 & 19 & 17 & 18 \\
\hline Prinsjesdag; & 37 & 24 & 7,1 & 61 & 22 & 26 & 24 \\
\hline $\begin{array}{l}\text { Large fundraising } \\
\text { campaign; }\end{array}$ & 37 & 24 & 7,2 & 66 & 17 & 20 & 19 \\
\hline Royal wedding & 36 & 26 & 7,1 & 65 & 19 & 19 & 17 \\
\hline All & 27 & 22 & 7,0 & 60 & 21 & 16 & 16 \\
\hline
\end{tabular}




\section{Bibliography}

Ammerman, Nancy Tatom, Sacred Stories, Spiritual Tribes. Finding Religion in Everyday Life. New York: Oxford University Press, 2014.

Appadurai, Arjun, Modernity at large. Cultural dimensions of globalization. (Public Worlds 1) Minneapolis: University of Minnesota Press, 1996.

Arnold, Jonathan, Music and Faith. Conversations in a Post-Secular Age. Suffolk: Boydell and Brewer 2019.

Asad, Talal, Formations of the Secular. Stanford: Stanford University Press, 2003.

Assmann, Jan, Religion and Cultural Memory: Ten Studies. Stanford: Stanford University Press, 2006.

Astley, Jeff, Ordinary Theology: Looking, Listening and Learning in Theology (Explorations in Practical, Pastoral and Empirical Theology). Aldershot: Ashgate 2002.

Aupers, Stef, "Spiritual Play. Encountering the sacred in World of Warcraft". In Playful Identities. The Ludification of Digital Media Cultures, edited by Valerie Frissen, Sybille Lammes, Michiel de Lange, Jos de Mul, and Joost Raessens. Amsterdam: Amsterdam University Press, 2015, 75-92.

Ballard, Paul, "The Use of Scripture". In The Wiley Blackwell Companion to Practical Theology, edited by Bonnie Miller-McLemore. Oxford: Wiley-Blackwell 2012, 163172.

Barnard, Marcel, Liturgiek als wetenschap van christelijke riten en symbolen (Inaugural lecture Universiteit van Amsterdam). Amsterdam: Amsterdam University Press 2000.

Barnard, Marcel and Paul Post, ed., Ritueel Bestek. Antropologische kernwoorden van de liturgie. Zoetermeer: Uitgeverij Boekencentrum, 2001.

Barnard, Marcel, "Ambivalent Images. Rethinking Biennale 52 Venice/ Documenta 12 Kassel and the Task of Practical Theology", International Journal of Practical Theology 14/1 (2010), 68-85.

Barnard, Marcel, Johan Cilliers, Cas Wepener, Mirella Klomp, Ronelle Sonnenberg, Stefan Belderbos, Nienke van Andel, "Investigating liturgical ritual". In Worship in the Network Culture. Liturgical Ritual Studies. Fields and Methods, Concepts and Metaphors. (Liturgia Condenda 28), edited by Marcel Barnard, Johan Cilliers, and Cas Wepener. Leuven [etc.]: Peeters, 2014, 49-63.

Barnard, Marcel, Johan Cilliers, Cas Wepener and Eward Postma. "Play/Function". In Worship in the Network Culture. Liturgical Ritual Studies. Fields and Methods, Concepts and Metaphors. (Liturgia Condenda 28), edited by Marcel Barnard, Johan Cilliers, and Cas Wepener. Leuven [etc.]: Peeters, 2014, 245-274.

Barnard, Marcel, Johan Cilliers, and Cas Wepener. Worship in the Network Culture. Liturgical Ritual Studies. Fields and Methods, Concepts and Metaphors. (Liturgia Condenda 28) Leuven [etc.]: Peeters, 2014. 
Barnard, Marcel, “Bijbellezen als textiele werkvorm. 'O Meester, Slaaf en Broeder, Geslachte en Verrezen God', Schrift. Tijdschrift over de Bijbel 270/46:1 (2014), 30-34.

Bauman, Zygmunt, Life in Fragments. Essays in Postmodern Morality. Oxford: Blackwell Publishers Ltd., 1995.

Bauman, Zygmunt, Liquid Modernity. Cambridge: Polity Press, 2000.

Bauman, Zygmunt, Liquid Life. Cambridge: Polity Press, 2005.

Beaman, Lori, “Battles over Symbols: The 'Religion' of the Minority versus the 'Culture' of the Majority", Journal of Law and Religion 28/1 (2013), 141-157.

Beaudoin, Tom, ed., Secular Music and Sacred Theology. Collegeville, MN: Liturgical Press 2013 .

Beck, Ulrich, A God of One's Own. Religion's Capacity for Peace and Potential for Violence. Cambridge: Polity, 2010.

Beckford, James, "Public Religions and the Postsecular: Critical Reflections", Journal for the Scientific Study of Religion 51/1 (2012), 1-19.

Benjamins, Rick, "The Postsecular and Systematic Theology. Reflections on Kearney and Nancy". International Journal of Philosophy and Theology 76/2 (2015), 116-128.

Berger, Peter, The Desecularization of the World. Resurgent Religion and World Politics. Grand Rapids, MI: Eerdmans, 1999.

Bergmann, Sigurd, "Theology in its Spatial Turn. Space, Place and Built Environments Challenging and Changing the Images of God", Religion Compass, 1/3 (2007), 353379.

Bernts, Ton, and Joantine Berghuijs, God in Nederland 1966-2015. Utrecht: Ten Have, 2016.

Bonhoeffer, Dietrich, Letters and Papers from Prison, [transl. from the German: Widerstand und Ergebung. Briefe und Aufzeichnungen aus der Haft, München 1951]. New York: Touchstone 1997 [1953], 280-282.

Borgdorff, Henk, The Conflict of the Faculties: Perspectives on Artistic Research and Academia. Leiden: Leiden University Press, 2012.

Borgman, Erik, Metamorfosen. Over religie en moderne cultuur. Kampen: Klement Pelckmans, 2006.

Brown, Callum, The Death of Christian Britain. Understanding Secularisation, 18002000. (Christianity and Society in the Modern World) London: Routledge, 2001.

Bruce, Steve, God Is Dead: Secularization in the West. Oxford \& Malden: Oxford University Press, 2002.

Brueggemann, Walter, The Land: Place as Gift, Promise and Challenge in Biblical Faith. Philadelphia: Fortress Press, 1977.

Cameron, Helen and Catherine Duce, Talking About God in Practice: Theological Action Research and Practical Theology. Norwich scm Press, 2010.

Campbell, Heidi, and Gregory Grieve, ed., Playing with Religion in Digital Games. (Digital Game Studies) Bloomington, IN: Indiana University Press, 2014. 
Campbell-Reed, Eileen, "The power and danger of a single case study in practical theological research". In Conundrums in Practical Theology, edited by Joyce Ann Mercer and Bonnie Miller-McLemore. (Theology in Practice 2) Brill, 2016, 33-59.

Casanova, Jose, Public Religions in the Modern World. Chicago: Chicago University Press, 1994.

Casanova, Jose, "Religion, European Secular Identities and European Integration". In Religion in an Expanding Europe, edited by Timothy A. Byrnes and Peter J. Katzenstein. Cambridge: Cambridge University Press, 2006, 65-92.

Casanova, Jose, "The Secular and Secularisms", Social Research 76/4 (2009), 1049-1066.

Casanova, Jose, "The Secular, Secularity, Secularism". In Rethinking Secularism, edited by Craig Calhoun, Mark Juergensmeyer, and Jonathan VanAntwerpen. Oxford: Oxford University Press, 2011, 54-74.

Castells, Manuel, The Information Age. Economy Society and Culture, vol. 1: The Rise of the Network Society. Oxford: Wiley-Blackwell, 2010 [1996].

Castells, Manuel, The Information Age. Economy Society and Culture, vol. 2: The Power of Identity. Oxford: Wiley-Blackwell, 2010 [1997].

Cavanaugh, William, The Myth of Religious Violence. Oxford: Oxford University Press, 2009.

Challand, Benoît, "From Hammer and Sickle to Star and Crescent: The Question of Religion for European Identity and a Political Europe", Religion, State and Society 37/1 (2009), 65-8o.

Charbonnier, Lars, Johan Cilliers, Matthias Mader, Cas Wepener and Birgit Weyel, ed., Pluralisation and social change. Dynamics of lived religion in South Africa and in Germany. Berlin: De Gruyter, 2018. Dor: 10.1515/9783110569810.

Cieślik-Klauza, Joanna, "Passion Music at the Turn of the XX and XXI Centuries, Part I: Sofia Gubaidulina and Wolfgang Rihm", Rocznik Teologii Katolickiej 17/1 (2018), 183194.

Cieślik-Klauza, Joanna, "Passion Music at the Turn of the XX and XXI Centuries, Part II: Tan Dun and Osvaldo Golijov", Rocznik Teologii Katolickiej 17/3 (2018), 107-117.

Cobussen, Marcel, "Verkenningen van/in een muzikale ruimte. Over Peter Sloterdijk en Edwin van der Heide". In Interakta $\#_{5}$. Grootstedelijke reflecties. Over kunst en openbare ruimte, edited by Henk Oosterling and Siebe Thissen. Rotterdam: Faculty of Philosophy, Erasmus University, 2002, 208-211.

Conradie, Ernst, "Towards a Towards a Theology of Place in the South African Context. Some Reflections from the Perspective of Ecotheology", Religion \& Theology 16 (2009), 3-18, 3. DOI: 10.1163/156973109X449967.

Coulson, J., C.T. Carr, Lucy Hutchinson, Dorothy Eagle, ed., The Oxford Illustrated Dictionary, 2nd ed. Oxford: Clarendon Press, 1978.

Danet, Brenda, Cyberpl@y. Communicating Online. Oxford/New York: Berg, 2001. 
Dark, Ken, "Large-scale Religious Change and World Politics". In Religion and International Relations, edited by Ken Dark. London: Macmillan, 2000, 50-82.

Davie, Grace, Religion in Britain. A Persistent Paradox. Chichester: Wiley-Blackwell, 2015.

Davis, Ellen and Richard Hays, ed., The Art of Reading Scripture. Grand Rapids, MI: Eerdmans, 2003.

De Hart, Joep, Maak het nieuw. Over religieuze ontwikkelingen en de positie van de kerken. Een persoonlijke geschiedenis. The Netherlands Institute for Social Research, 2011-34, Den Haag, 2011.

De Hart, Joep, Paul Dekker and Loek Halman, Religion and Civil Society in Europe. Dordrecht: Springer, 2013. DOI: 10.1007/978-94-007-6815-4.

De Hart, Joep, Geloven binnen en buiten verband: godsdienstige ontwikkelingen in Nederland. Den Haag: Sociaal en Cultureel Planbureau, 2014.

De Hart, Joep, "Summary. Keeping the faith? Trends in religion in the Netherlands", in Joep de Hart, Geloven binnen en buiten verband: godsdienstige ontwikkelingen in Nederland. The Netherlands Institute for Social Research 2014-10, Den Haag: Sociaal en Cultureel Planbureau, 2014, 130-134.

De Hart, Joep and Paul Dekker, "Floating Believers: Dutch Seekers and the Church". In The Appeal of a Catholic Minority Church in a World of Seekers. (Christian Philosophical Studies XI), edited by Staf Hellmans and Peter Jonkers. Washington: The Council for Research in Values and Philosophy, 2015, 71-96.

De Hart, Joep, "Verleden heb je, toekomst kun je krijgen" in Ton Bernts and Joantine Berghuijs, God in Nederland 1966-2015. Utrecht: Ten Have, 2016, 7-9.

De Hart, Joep and Pepijn van Houwelingen, Christenen in Nederland. Kerkelijke deelname en christelijke gelovigheid. Den Haag: Sociaal en Cultureel Planbureau, 2018.

De Hek, Willem Jan, Strolling through Mokum. The Dynamics of Place-making, Sacredness and Souls in the City of Amsterdam. (Master thesis Protestant Theological University 2017), S.l.s.n.

De Ruijter, Martijn, Confining frailty. Making place for ritual in rest and nursing homes. (Netherlands Studies in Ritual and Liturgy 18) Groningen/Amsterdam: Institute for Christian Cultural Heritage/Instituut voor Rituele en Liturgische Studies, 2016.

Deumert, Ana, "The performance of a ludic self an social network(ing) sites". In The Language of Social Media. Identity and Community on the Internet, edited by Philip Seargeant and Caroline Tagg. Basingstoke/New York: Palgrave Macmillan 2014, 2345 .

Dibbell, Julian, "The Chinese Game Room. Play, Productivity, and Computing at Their Limits". Artifact 2.2 (2008), 82-87. Dor: 10.1080/17493460903020141.

Donk, Wim B. H. J. van de [e.a.], ed., Geloven in Het Publieke Domein. Verkenningen Van Een Dubbele Transformatie. (WRR Verkenningen 13) Amsterdam: Amsterdam University Press, 2006. 
Dreyer, Jaco, "Do we live in a secular world? An African perspective". In Secularization Theories, Religious Identity and Practical Theology. Developing International Practical Theology for the 21st Century. (International Practical Theology 7), edited by Wilhelm Gräb and Lars Charbonnier. Münster/Zürich: Lit Verlag, 20o9, 35-62.

Droogers, André, "The Third Bank of the River. Play, Methodological Ludism and the Definition of Religion". In Playful Religion. Challenges for the Study of Religion. Delft: Eburon, 2006, 75-96.

Droogers, André, Play and Power in Religion: Collected Essays. Berlin: De Gruyter, 2012. Droogers, André, Religion at play. A Manifesto. Eugene, on: Wipf and Stock, 2014.

Durkheim, Emile, The elementary forms of religious life, Trans. Karen Fields. New York: The Free Press, 1995 (originally published in 1912).

Eliade, Mircea, The Sacred and The Profane. The Nature of Religion. London: Harcourt Brace Jovanovich, 1987 .

Evans, Carolyn, "The 'Islamic Scarf' in the European Court of Human Rights", Melbourne Journal of International Law 7/1 (2006), 52. http://www.austlii.edu.au/au/ journals/MelbJIL/2006/4.html. Last accessed 26 September 2016.

Evans, Matthew, "The sacred. Differentiating, clarifying, and extending concepts", Review of Religious Research 45, no. 1 (2003), 32-47.

Faro, Laurie, Postponed monuments in the Netherlands. Manifestation, context, and meaning. (PhD thesis, Tilburg School of Humanities), s.l., 2015.

Fauconnier, Gilles, Mental Spaces. Aspects of Meaning Construction in Natural Language. Cambridge: Cambridge University Press, 2010.

Feld, Steven, "Waterfalls of Song. An Acoustemology of Place Resounding in Bosavi, Papua New Guinea". In Senses of Place, edited by Steven Feld and Keith H. Basso. School of American Research Press, 1996, 91-136.

Flyvbjerg, Bent. "Five Misunderstandings About Case-Study Research". Qualitative Inquiry 12, no. 2 (2006), 219-245.

Foret, Francois, "Religion: A Solution or a Problem for the Legitimisation of the European Union?” Religion, State and Society 37/1 (2009), 37-50.

Foucault, Michel, “Of Other Spaces, Heterotopias", Translated from Architecture, Mouvement, Continuité 5 (1984).

Frijhoff, Willem, Heiligen, idolen, iconen (inaugural address vu University Amsterdam). Nijmegen: sun, 1998.

Frijhoff, Willem, and Marijke Spies. Dutch Culture in a European Perspective: 1950, Prosperity and Welfare. Assen: Uitgeverij Van Gorcum, 2004.

Frissen, Valerie, Sybille Lammes, Michiel de Lange, Jos de Mul, Joost Raessens, ed., Playful Identities. The Ludification of Digital Media Cultures. Amsterdam: Amsterdam University Press, 2015. 
Ganzevoort, Ruard and Johan Roeland, "Lived religion: The praxis of practical theology", International Journal of Practical Theology 18/1 (2014), 1-11. DOI: 10.1515/ijpt-2014 -0007.

Gerhards, Albert, "Prozession II". In Theologische Realenzyklopädie 27, edited by Horst Balz et al. Berlin: De Gruyter, 1997, 593-597.

Gertz, Jan Christian, "Prozession I". In Theologische Realenzyklopädie 27, edited by Horst Balz et al. Berlin: De Gruyter, 1997, 591-593.

Giddens, Anthony, The Consequences of Modernity. Cambridge: Polity, 1990.

Gómez, Liliana, "The Urbanization of Society. Towards a Cultural Analysis of the Sacred in the Modern Metropolis". In The Sacred in the City, edited by Liliana Gómez and Walter van Herck. London/New York: Continuum, 2012, 31-51.

Goto, Courtney, "Reflecting Theologically by Creating Art: Giving Form to More than We Can Say", Reflective Practice: Formation and Supervision in Ministry 36 (2016), 78-92. http://journals.sfu.ca/rpfs/index.php/rpfs/article/view/426/413.

Graham, Elaine, "What we make of the world. The turn to 'culture' in theology and the study of religion". In Between sacred and profane. Researching religion and popular culture, edited by Gordon Lynch, 63-81. London: I.B. Tauris, 2007, 63-81.

Graham, Elaine, Between a Rock and a Hard Place. Public Theology in a Post-Secular Age. London: ScM Press, 2013.

Green, Maia, "Confronting Categorical Assumptions about the Power of Religion in Africa", Review of African Political Economy 33/110 (2006), 635-650.

Grimes, Ronald L., "Jonathan Z. Smith's theory of ritual space", in Religion 29 (1999), 262-273.

Grimes, Ronald L., Rite out of Place: Ritual, Media and the Arts. Oxford: Oxford University Press, 2006.

Grimes, Ronald L., Ritual Criticism. Case Studies in its Practice, Essays on its Theory. Waterloo, Canada: Ritual Studies International, 2010 [199o].

Gruber, Judith, Theologie nach dem Cultural Turn: Interkulturalität als theologische Ressource. Stuttgart: Kohlhammer 2013.

Guardini, Romano, The Spirit of the Liturgy. Trans. Ada Lane. London: Sheed and Ward, 1937 [1935].

Guesnet, François, Cécile Laborde and Lois Lee, ed., Negotiating Religion. Crossdisciplinary perspectives. New York: Routledge International, 2017.

Habermas, Jürgen, "Religion in the Public Sphere", European Journal of Philosophy 14/1 (2006), 1-25.

Hamman, Jaco. "Playing”. In The Wiley Blackwell Companion to Practical Theology, edited by Bonnie Miller-McLemore, 42-5o. Oxford: Wiley-Blackwell, 2012.

Heaphy, Brian, Late Modernity and Societal Change. Reconstruction Social and Personal Life. London: Routledge, 2007. 
Heidbrink, Simone, Jan Wysocki and Tobias Knoll, ed., Religion in Digital Games Reloaded. Immersion Into the Field (Online - Heidelberg Journal of Religions on the Internet 7). Heidelberg: University of Heidelberg, 2015.

Held, David, "Democracy, the nation-state and the global system". Economy and Society 20/2 (1991), 138-172.

Hjarvard Stig and Mia Lövenheim, ed., Mediatization and Religion. Nordic Perspectives. Göteborg: Nordicom, 2012.

Hjarvard, Stig, The mediatization of culture and society. London: Routledge, 2013.

Hoondert, Martin, Om de parochie. Ritueel-muzikale bewegingen in de marge van de parochie. Gregoriaans, Taizé, Jongerenkoren. Heeswijk: Abdij van Berne, 2006.

Hoondert, Martin and Mirella Klomp, "The Streets of Gouda". In Sacred Spaces and Contested Identities. Space and ritual dynamics in Europe and Africa, edited by Paul Post, Philip Nel and Wouter van Beek. Trenton, NJ: Africa World Press, 2014, 313-33o.

Houtman, Dick, Stef Aupers, \& Paul Heelas, "Christian Religiosity and New Age Spirituality: Cross-Cultural Comparison”, Journal for the Scientific Study of Religion 48/1 (2009), 169-179.

Howie, Alan, "Bruckner and The Motet". In The Cambridge Companion to Bruckner, Cambridge Companions to Music, ed. J. Williamson. Cambridge: Cambridge University Press, 2004. DOI: 10.1017/CCOL9780521804042.006.

Huizinga, Johan, Homo Ludens. A Study of the Play-Element in Culture, London/Boston/ Henley: Routledge and Kegan Paul, 1949 (= Proeve eener bepaling van het spelelement der cultuur. Haarlem: H.D. Tjeenk Willink \& Zoon. 1938). Online. http://art .yale.edu/file_columns/oooo/1474/homo_ludens_johan_huizinga_routledge_1949_ .pdf. Last accessed 8 August 2018.

Hurd, Elizabeth Shakman, The Politics of Secularism in International Relations. Princeton: Princeton University Press, 2008.

Hurd, Elizabeth Shakman, Beyond Religious Freedom: The New Global Politics of Religion. Princeton: Princeton University Press, 2015.

Hüsken, Ute, "Ritual Dynamics and Ritual Failure". In Ute Hüsken, ed. When Rituals Go Wrong, 337-366.

Hüsken, Ute (ed.), When Rituals Go Wrong. Mistakes, Failure and the Dynamics of Ritual, Numen Book Series 115, Leiden: Brill, 2007.

Hutchings, Tim, Creating Church Online. Ritual, Community and New Media. New York: Routledge, 2017.

Jenkins, Philip, The Next Christendom. The Coming of Global Christianity. Oxford: Oxford University Press, 2002.

Jenkins, Henry, Convergence culture. Where old and new media collide. New York: New York University Press, 2006.

Jenny, Marcus, "Hymnologie". In Theologische Realenzyklopaedie, edited by Gerhard Krause and Gerhard Müller. Berlin: De Gruyter, 1986, 15: 770-778. 
Juchtmans, Goedroen, Rituelen thuis: van christelijk tot basaal sacraal. Een exploratieve studie naar huisrituelen in de Tilburgse nieuwbouwwijk De Reeshof. (Netherlands Studies in Ritual and Liturgy 8) Groningen/Tilburg: Instituut voor Liturgiewetenschap/Instituut voor Rituele en Liturgische Studies, 2008.

Juergensmeyer, Mark, The New Cold War? Religious Nationalism Confronts the Secular State. Berkeley \& Los Angeles: University of California Press, 1994.

Kearney, Richard, Anatheism. Returning to God after God. New York: Columbia University Press, 2011.

Kearney, Richard, The God Who May Be. A Hermeneutics of Religion. (Indiana Series in the Philosophy of Religion) Bloomington, IN: Indiana University Press, 2001.

Kim, Sebastian, "Editorial", International Journal of Public Theology, 1/1 (2007), 1-4.

Klomp, Mirella, The Sound of Worship. Liturgical Performance by Surinamese Lutherans and Ghanaian Methodists in Amsterdam. (Liturgia Condenda 26) Leuven [etc.]: Peeters, 2011.

Klomp, Mirella, "Joseph \& Jesus. Bible-based musicals and contemporary Passions staged in the public domain: an exploration of a research perspective". Yearbook for Liturgical and Ritual Studies 27 (2011), 49-65.

Klomp, Mirella, "Moderne liturgie, stadsmarketing of heiligschennis? Reflectie op The Passion vanuit cultureel-antropologisch perspectief", Handelingen. Tijdschrift voor Praktische Theologie en Religiewetenschap 4 (2012), 45-54.

Klomp, Mirella, “The Passion' met God als optie”. Kerk en Theologie 66/2 (2015), 134140.

Klomp, Mirella, "Staging the Resurrection. The Public Theology of Dutch Production and Broadcasting Companies". International Journal of Public Theology 9/4 (2015), 446-464.

Klomp, Mirella and Marcel Barnard, "Sacro-Soundscapes. Interpreting Contemporary Ritual Performances of Sacred Music through the Case of The Passion in the Netherlands", International Journal of Practical Theology 21/2 (2017), 240-258. DOI: 10.1515/ijpt-2016-oo3o.

Klomp, Mirella and Marten van der Meulen, "The Passion as ludic practice - understanding public ritual performances in late modern society: a case study from the Netherlands", Journal of Contemporary Religion 32/3 (2017), 387-401. DOI: 10.1080/ 13537903.2017.1362879.

Klomp, Mirella and Danie Veldsman, "After God, But Behind the Cross. The Procession as a Way to Re-encounter God in a Culture Beyond Classical Liturgy". Studia Liturgica. An International Ecumenical Review for Liturgical Research and Renewal 47/1 (2017), 15-29.

Klomp, Mirella, Marten van der Meulen, Erin Wilson and Anita Zijdemans, "The Passion as Public Reflexivity: How the Dutch in a Ritual-musical Event Reflect on Re- 
ligious and Moral Discussions in Society", Journal of Religion in Europe 11 (2018), 195-221. DOI: 10.1163/18748929-01102007.

Knibbe, Kim, Marten van der Meulen, and Peter Versteeg, "Fieldwork on Ritual: Understanding Through Participation". In Methods for the Study of Religious Change. From Religious Studies to Worldview Studies, edited by André Droogers and Anton van Harskamp. Sheffield: Equinox Publishing, 2014, 87-110.

Knott, Kim, The Location of Religion. A Spatial Analysis. London: Routledge, 2005.

Kuru, Ahmet, Secularism and State Policies Towards Religion. Cambridge: Cambridge University Press, 2009.

Laermans, Rudi, Bryan Wilson, and Jaak Billiet, Secularization and Social Integration. Papers in Honor of Karel Dobbelaere. (Sociologie Vandaag 4) Leuven: Leuven University Press, 1998.

Lang, Bernhard, Sacred Games. A History of Christian Worship. New Haven: Yale University Press, 1997.

Lartey, Emmanuel, "Postcolonial African practical theology. Rituals of remembrance, cleansing, healing and re-connection", Journal of Pastoral Theology 21/2 (2011), 1-17. DOI: 10.1179/jpt.2011.21.2.002.

Leaver, Robin, "Passion Play". In The Cambridge Dictionary of Christianity, edited by Daniel Patte. Cambridge: Cambridge University Press, 2010, 926.

Leeuw, Gerardus van der, Religion in Essence and Manifestation. A Study in Phenomenology [transl. from the German: Phänomenologie der Religion, Tübingen 1933]. New Jersey: Princeton University Press, 2014 [1938].

Lefebvre, Henri, The Production of Space. Oxford/Cambridge: Blackwell, 1991.

Leustean, Lucian, and John Madeley, "Introduction: Religion, Politics and Law in the European Union". In Religion, Politics and Law in the European Union, edited by Lucian Leustean and John Madeley. London: Routledge, 2009, 1-16.

Leustean, Lucian, and John Madeley, "Religion, Politics and Law in the European Union: An Introduction", Religion, State and Society 37/1 (2009), 3-18.

Luther, Martin, D. Martin Luther's Werke. (Weimarer Ausgabe 40) Weimar: Boehlau, 1911.

Lynch, Gordon, Between Sacred and Profane. Researching Religion and Popular Culture. London: I.B. Tauris, 2007.

Lynch, Gordon, The Sacred in the Modern World. A Cultural Sociological Approach. Oxford: Oxford University Press, 2012.

Malacarne, Ivan Kiper and Júlio Cézar Adam, "Comensais da morte ou da vida? Contribuições da religião vivida para a teologia cristã a partir da série literária Harry Potter" ("Death or life Eaters? Contributions of lived religion to Christian theology from the Harry Potter literary series"), Tear Online 8/2 (2019), 114-126. 
Margry, Peter Jan, Teedere Quaesties: religieuze rituelen in conflict. Confrontaties tussen katholieken en protestanten rond de processiecultuur in 19e-eeuws Nederland. (PhD thesis University of Amsterdam) Hilversum: Verloren, 2000.

Marshall, Ruth, Political Spiritualities: The Pentecostal Revolution in Nigeria. Chicago: Chicago University Press, 2009.

Marti, Gerardo, and Gladys Ganiel, The Deconstructed Church: Understanding Emerging Christianity. Oxford: Oxford University Press, 2014.

Mason, Jennifer, Qualitative Researching (3rd edition). Los Angeles: Sage, 2018.

Mason, Jennifer, Qualitative Researching (2nd edition). London: Sage, 2002.

McAlister, Elizabeth, "Globalization and the Religious Production of Space",Journal for the Scientific Study of Religion 44/3 (2005), 249-255.

McClure, John, Mashup Religion. Pop Music and Theological Invention. Waco, TX: Baylor University Press, 2011.

Mepschen, Paul, Jan Willem Duyvendak and Evelien Tonkens, "Sexual Politics, Orientalism and Multicultural Citizenship in the Netherlands", Sociology 44/5 (2010), 962-979.

Mercer, Joyce Ann, "Interdisciplinarity as a practical theological conundrum", in Conundrums, eds. Mercer and Miller-McLemore, 163-189.

Meuzelaar, Andrea, Seeing through the archival prism: A history of the representation of Muslims on Dutch television. (PhD thesis University of Amsterdam), S.l.s.n. 2014. Accessed via https://pure.uva.nl/ws/files/2451561/151502_Thesis_complete_1_pdf.

Miller-McLemore, Bonnie, "Five Misunderstandings about Practical Theology", International Journal of Practical Theology 16/1 (2012), 5-26. DoI: 10.1515/ijpt-2012-0002.

Miller-McLemore, Bonnie, ed., The Wiley Blackwell Companion to Practical Theology. Oxford: Wiley-Blackwell, 2012.

Murray Schafer, Raymond, The soundscape: our sonic environment and the tuning of the world. Rochester: Destiny Books, 1993.

Nasrallah, Rima, Moving and Mixing. The Fluid Liturgical Lives of Antiochian Orthodox and Maronite Women Within the Protestant Churches in Lebanon (PhD dissertation Protestant Theological University), s.l. 2015, http://theoluniv.ub.rug.nl/153/1/ NasrallahR_MovingandMixing_18febr2015.pdf. Last accessed April 2, 2020.

Nietzsche, Friedrich, The Gay Science $(1882,1887)$ par. 125; Walter Kaufmann ed. and transl. New York: Vintage, 1974, 181.

Norris, Pippa and Ron Inglehart, Sacred and Secular. Religion and Politics Worldwide. Cambridge: Cambridge University Press, 2004.

Oosterbaan, Martijn, "Sonic Supremacy. Sound, Space and Charisma in a Favela in Rio de Janeiro", Critique of Anthropology 29/1 (2009), 81-104.

Osmer, Richard, The Teaching Ministry of Congregations. Louisville: Westminster John Knox Press, 2005.

Osmer, Richard, Practical Theology, An introduction. Grand Rapids: Eerdmans, 2008. 
Osmer, Richard, "Practical theology: A current international perspective", HTs Teologiese Studies/ Theological Studies 67(2), 2011. \#Art. 1058, 7 pages. http://dx.doi.org/ 10.4102/hts.v67i2.1058.

Parker-Jenkins, Marie, "Problematising ethnography and case study": reflections on using ethnographic techniques and researcher positioning", Ethnography and Education 13/1 (2018), 18-33. DOI: 10.1080/17457823.2016.1253028.

Pattison, Stephen, The Challenge of Practical Theology. Selected Essays. London: Jessica Kingsley, 2007.

Paul, Herman, "The Sociological Myth: A 1954 Controversy on Secularization Narratives", Journal of Religion in Europe 9/2-3 (2016), 201-224.

Paul, Herman, De slag om het hart. Over secularisatie van verlangen. Utrecht: Boekencentrum, 2017.

Petersen, William, "Holy Week in the 'Heart of the Philippines': Spirituality, Theatre and Community in Maranduque's Moriones Festival", Asian Theatre Journal 24/2 (2007), 309-337.

Philpott, Daniel, "The Challenge of September 11 to Secularism in International Relations", World Politics 55/1 (2002), 66-95.

Plasketes, George, Play it again. Cover songs in popular music. Surrey: Ashgate 2010.

Plate, Brent, "Religion is Playing Games: Playing Video Gods, Playing to Play". Religious Studies and Theology 29/2 (2010), 215-230.

Porter, Mark, “The Developing Field of Christian Congregational Music Studies", Ecclesial Practices. Journal of ecclesiology and ethnography 1/2 (2014), 149-166.

Post, Paul, "Ritual Landscape. On Outdoor Liturgy. Processional Parks, Papal Visits, and Popular Rites Associated with Sudden Death". In The Modern Pilgrim. Multidisciplinary Explorations of Christian Pilgrimage (Liturgia Condenda 8), edited by Paul Post, Ronald L. Grimes, Albertine Nugteren, Per Pettersson, Hessel Zondag. Leuven: Peeters Publishers, 1998, 281-320.

Post, Paul, "Speelruimte voor Heilig Spel”. In Over spel. Theologie als drama en illusie, edited by Herman Beck, Rein Nauta and Paul Post. Leende: Damon, 200o, 139-167.

Post, Paul, "Case studies I: Dutch cases and themes". In Disaster ritual. Explorations of an emerging ritual repertoire. (Liturgia Condenda 15), edited by Paul Post, Ronald L. Grimes et al. Leuven: Peeters Publishers, 2003, 156-186.

Post, Paul, "Heilige velden. Panorama van ritueel-religieuze presenties in het publieke domein", Tijdschrift voor Religie, Recht en Beleid 1/3 (2010), 70-91.

Post, Paul and Arie Molendijk, ed., Holy Ground. Re-inventing Ritual Space in Modern Western Culture. Leuven: Peeters Publishers, 2010.

Post, Paul, Arie L. Molendijk, and Justin Kroesen, Sacred Places in Modern Western Culture. Leuven [etc.]: Peeters, 2011.

Post, Paul, "Panorama der Ritual Studies. Trends und Themen der aktuellen Ritual Studies", Archiv für Liturgiewissenschaft (2013), 139-181. 
Post, Paul, "Complexity and conflict. The contemporary European church building as ambiguous sacred space". In Sacred Spaces and Contested Identities, edited by Post, Paul, Philip Nel and Walter van Beek, 241-265.

Post, Paul, Philip Nel and Walter van Beek, ed., Sacred Spaces and Contested Identities. Space and ritual dynamics in Europe and Africa. Trenton: Africa World Press, 2014.

Raessens, Joost, "The Ludification of Culture". In Rethinking Gamification, edited by Mathias Fuchs, Sonia Fizek, Paolo Ruffino and Niklas Schrape. Lüneburg: Hybrid Publishing Lab, 2014, 91-114. Online. http://gamification-research.org/2014/o6/ edited-volume-rethinking-gamification-out/.

Relph, Edward, Place and Placelessness, 14th ed. Los Angeles (CA): Sage, 2016.

Rey, Pedro, "Gamification and Post-Fordist Capitalism". The Gameful World. Approaches, Issues, Applications, ed. Steffen P. Walz and Sebastian Deterding. Cambridge (MA): The MIT Press, 2014, 277-295. http://pjreyresearch.com/\#_=_. Retrieved August 31, 2016.

Ribberink, Egbert, Peter Achterberg and Dick Houtman, "Religious polarization: contesting religion in secularized Western European countries”, Journal of Contemporary Religion 33/2 (2018), 209-227. DOI: 10.108o/13537903.2018.1469262.

Richards, Greg, Leisure in the Network Society. From Pseudo-Events to Hyperfestivity? (Inaugural lecture) Tilburg: Tilburg University, 2010.

Rijken, Hanna, 'My Soul Doth Magnify'. The Appropriation of the Anglican Choral Evensong in the Netherlands (PhD thesis Protestant Theological University, Amsterdam, 2017). S.l., s.n.

Roeland, Johan, Miranda Klaver, Marten van der Meulen, Remco van Mulligen, Hijme Stoffels, and Peter Versteeg. 'CCan we dance in this place?' Body Practices and Forms of Embodiment in Four Decades of Dutch Evangelical Youth Events". Journal of Contemporary Religion 27/2 (2012), 241-256. DOI: 10.1080/13537903.2012.675736.

Rowe, Sharon, "Modern Sports: Liminal Ritual or Liminoid Leisure". In Victor Turner and Contemporary Cultural Performance, edited by Graham St. John. New York \& Oxford: Berghahn Books, 2008, 127-148.

Sample, Tex, The Spectacle of Worship in a Wired World. Electronic Culture and the Gathered People of God. Nashville, TN: Abingdon Press, 1998.

Schieffelin, Edward L., "Introduction”. In Ute Hüsken, ed. When Rituals Go Wrong, 1-2o. Schipani, Daniel, “Case Study Method”. In The Wiley-Blackwell Companion, ed. MillerMcLemore, 91-101.

Schippers, Inez, Sacred places in the suburbs. Casual sacrality in the Dutch VINEXdistrict Leidsche Rijn. (Netherlands Studies in Ritual and Liturgy 16) Groningen/ Amsterdam: Institute for Christian Cultural Heritage/Institute for Ritual and Liturgical Studies, 2015 .

Schulz, Dorothea, "Soundscape". In Key Words in Religion, Media and Culture, edited by David Morgan. New York: Abingdon, 2008, 176-186. 
Seed, John, “'Secular' and 'Religious'. Historical Perspectives”. Social History 39/1 (2014), $3^{-13}$.

Selderhuis, Herman, ed., "The Further Reformation”. Handbook of Dutch Church History. Bristol, CT: Vandenhoeck \& Ruprecht, 2014, 338-341.

Sengers, Erik, ed., The Dutch and their gods. Secularization and transformation of religion in the Netherlands since 1950. (ReLic 3) Hilversum: Verloren, 2005.

Shenton, Andrew, "For whom the bells toll. Arvo Part's Passio, metamodernism and the appealing promise of tintinnabulation". In Contemporary Music and Spirituality, edited by Robert Sholl and Sander van Maas. Oxford/New York: Routledge 2017, 1736.

Sheppard, Phillis “Womanist Pastoral Theology and Black Women's Experience of Gender, Religion, and Sexuality". In Pastoral Theology and Care. Critical Trajectories in Theory and Practice, ed. Nancy J. Ramsay. D oI: 10.1002/9781119292586.ch6.

Sloterdijk, Peter, In hetzelfde schuitje: proeve van een hyperpolitiek. Amsterdam: Arbeiderspers 1997.

Smit, Peter-Ben, "Authority in the New Testament and the New Testament's Authority", Eccesiology 13 (2017), 83-101.

Smith, Jonathan Z., To Take Place. Toward Theory in Ritual. Chicago: University of Chicago Press, 1992.

Soja, Edward, Thirdspace.Journeys to Los Angeles and Other Real-and-imagined Places. Malden, MA: Wiley-Blackwell, 1996.

Sonnenberg, Ronelle, Malan Nel, Jos de Kock and Marcel Barnard, "Shaping Youth Worship. Modes of active participation". Questions Liturgiques 95/3-4 (2014), 216236.

Sparks, Logan, Ambiguous Spaces. A Contextualisation of Shared Pilgrimage in Ephesus. (PhD thesis, Tilburg School of Humanities), s.l., 2011. https://pure.uvt.nl/ws/ portalfiles/portal/1375419/Sparks_ambiguous_16-12-2011.pdf.

Stengs, Irene, "Public practices of commemorative mourning". In Holy Ground, edited by Post, Paul and Arie Molendijk, 119-143.

Swift, Graham, Mothering Sunday. A Romance. London: Scribner 2016.

Taylor, Charles. A Secular Age. Cambridge, MA: Harvard University Press 2007.

Thissen, Judith, Robert Zwijnenberg, and Kitty Zijlmans, Contemporary Culture. New Directions in Art and Humanities Research. Amsterdam: Amsterdam University Press, 2013. www.oapen.org/download?type=document\&docid $=450850$.

Tonnaer, Judith, Bomen voor het leven: Een studie naar een hedendaags collectief herdenkingsritueel voor overleden kankerpatiënten. (Netherlands Studies in Ritual and Liturgy 11) Groningen/Tilburg: Instituut voor Liturgiewetenschap/Instituut voor Rituele en Liturgische Studies, 2010.

Truax, Barry, Acoustic communication. Norwood: Ablex, 1984. 
Tuan, Yi-Fu, Space and Place: The Perspective of Experience. Minneapolis: University of Minnesota Press, 1977.

Turner, Victor, "Frame, Flow and Reflection: Ritual and Drama as Public Liminality". Japanese Journal of Religious Studies 6/4 (1979), 465-499. Online. https://nirc .nanzan-u.ac.jp/nfile/2195. Last accessed 8 August 2018.

Turner, Victor, From Ritual to Theatre. The Human Seriousness of Play. New York: Performing Arts Journal Publications, 1982.

Turner, Victor, The anthropology of performance. New York: PAJ Publications, 1988.

Tweed, Thomas, Crossing and Dwelling. A Theory of Religion. Cambridge, MA: Harvard University Press, 2006. DoI: 10.4159/9780674044517.

Van Aarde, Andries, "What is "theology" in "public theology" and what is "public" about "public theology"?" HTs Teologiese Studies / Theological Studies 64/3 (2008), 12131234. DOI: 10.4102/hts.v64i3.81.

Van den Brink, Gabriel, 'De migratie van het goddelijke. Over geloof en kerk in de moderne maatschappij'. In Geloven in het publieke domein: Verkenningen van een dubbele transformatie (WRR Verkenningen 13), edited by W. van de Donk, et al. Amsterdam: Amsterdam University Press, 2006, 417-433.

Van den Hemel, Ernst, "The Dutch War on Easter. Secular Passion for Religious Culture \& National Rituals", Yearbook for Ritual and Liturgical Studies 33 (2017), 1-19. DoI: $10.21827 / 5$ a2e424cb591e.

Van der Leeuw, Gerardus, Religion in Essence and Manifestation. A Study in Phenomenology [transl. of Phänomenologie der Religion, Tübingen 1933]. New Jersey: Princeton University Press 2014 [1938].

Van Rooden, Peter, "Oral History en het vreemde sterven van het Nederlandse Christendom [Oral History and the Strange Death of Dutch Christendom]". Bijdragen en Mededelingen betreffende de geschiedenis der Nederlanden 119/4 (2004), 524-551. DoI: $10.1835^{2} /$ bmgn-lchr.6138.

Vellenga, Sipco, "Anti-Semitism and Islamophobia in the Netherlands: concepts, developments, and backdrops", Journal of Contemporary Religion, 33/2 (2018), 175-192. DOI: 10.1080/13537903.2018.1469257.

Venbrux, Eric "Ritual Space and Ritual Gesture. Three types of ritual communication in throwing coins into the water". In Holy Ground, edited by Post, Paul and Arie Molendijk, 301-312.

Versteeg, Peter, "Playing Religion? Experience, Meaning and the Ludic Approach". In Playful Religion. Challenges for the Study of Religion, edited by Anton van Harskamp, Miranda Klaver, Johan Roeland, and Peter Versteeg. Delft: Eburon, 2006, 97-108.

Von Fischer, Kurt, Die Passion. Musik zwischen Kunst und Kirche. Kassel 1997.

Walton, Heather, "Poetics". In The Wiley Blackwell Companion to Practical Theology, edited by Bonnie Miller-McLemore. Oxford: Wiley-Blackwell, 2012, 173-182.

Ward, Pete, Liquid Church. Carlisle: Paternoster Press, 2002. 
Ward, Pete, Participation and Mediation. A Practical Theology for the Liquid Church. London: scm Press, 2008.

Wennekes, Emiel, "Wie zingt nu eigenlijk de paashaas? Nederland en de MatthäusPassion”. In De geheimen van de Matthäus-passion. Ambacht en mystiek van een meesterwerk, edited by Pieter Dirksen, 105-123. Amsterdam: Balans 2010.

Wijnia, Lieke and Mirella Klomp, "Tarenskeen's Luther. Allowing for New Forms of Sacrality". Yearbook for Ritual and Liturgical Studies 30 (2014), 243-259. https://ugp .rug.nl/jvlo/article/view/14666/12173.

Wijnia, Lieke, Making sense through music. Perceptions of the Sacred at Festival Musica Sacra Maastricht (PhD thesis Tilburg University). S.l., 2016. Online via https://pure .uvt.nl/ws/portalfiles/portal/1625o328/wijnia_making_12_o9_2016.pdf.

Willaime, Jean-Paul, "European Integration, Laïcité and Religion", Religion, State and Society 37/1 (2009), 23-35.

Wilson, Bryan, "The Secularization Thesis. Criticisms and Rebuttals". In Secularization and Social Integration. Papers in Honor of Karel Dobbelaere. (Sociologie Vandaag 4), edited by Laermans, Rudi, Bryan Wilson, and Jaak Billiet. Leuven: Leuven University Press, 1998, 45-65.

Wilson, Erin, and Luca Mavelli, "The Refugee Crisis and Religion: Beyond Conceptual and Physical Boundaries". In The Refugee Crisis and Religion: Secularity, Security and Hospitality in Question, edited by Luca Mavelli and Erin Wilson. London: Rowman and Littlefield International, 2017, 1-22.

Wilson, Erin, and Manfred Steger, "Religious Globalisms in a Post-secular Age", Globalizations 10/3 (2013), 481-495.

Wiman, Christian, My Bright Abyss. Meditation of a Modern Believer. New York: FsG Books, 2013.

Wuthnow, Robert, After Heaven. Spirituality in America since the 1950s. Oakland, CA: University of California Press, 1998.

Zappavigna, Michele, "CoffeeTweets. Bonding around the bean on Twitter", in Philip Seargeant and Caroline Tagg (eds.), The Language of Social Media. Identity and Community on the Internet. Basingstoke/New York: Palgrave Macmillan, 2014, 139-16o.

\section{Internet Sources}

"Aan het College van Burgemeester en Wethouders van de gemeente Gouda", (letter of objection against The Passion), Gereformeerde Gemeente Gouda et al., obtained via http://www.nd.nl/images/library/PDF/gouda.pdf on March 22, 2012.

"Aim", Eye2Eye Media, http://www.eyezeyemedia.nl/index.php?option=com_content \&view=article\&id=\&Itemid=101\&lang=en. Last accessed January 25, 2016. 
Algemeen Dagblad, “Amersfoort mag blij zijn met het krijgen van The Passion”, January 23, 2016, http://www.ad.nl/amersfoort/amersfoort-mag-blij-zijn-met-het -krijgen-van-the-passion ae35ccfe/. Last accessed May 10, 2020.

Algemeen Dagblad, "De Buisonjé: kom allemaal naar The Passion als signaal”, March 24, 2016, http://www.ad.nl/binnenland/de-buisonje-kom-allemaal-naar-the-passion -als-signaal a13bee33/. Last accessed May 10, 2020.

Amersfoortse gidsen, "Kerkenwandeling Amersfoort", http://amersfoortsegidsen.nl/ culturele\%2ouitjes/kerkenwandelingamersfoort.html. Last accessed May 1, 2016.

ANP (Netherlands national news agency), "Hoe God (bijna) verdween uit Nederland”, 13 March 2016. http://nos.nl/artikel/2092498-hoe-god-bijna-verdween-uit -nederland.html. Last accessed May 10, 2020.

Barnard, Marcel "Practices Research Program", Protestant Theological University, https://www.pthu.nl/Onderzoek-PThU/Practices/onderzoeksprogramma-prac tices.pdf. Last accessed May 10, 2020.

в вС, “The Manchester Passion". April 13, 2006. http://www.bbc.co.uk/manchester/ content/articles/2006/04/10/140406_manchester_passion_event_feature.shtml.

Last accessed May 10, 2020.

в вС, "Heaven knows it's Manchester now", Last updated April 13, 2006, https://bbc.in/ ${ }_{2} \mathrm{MrmQ2V}$. Last accessed May 10, 2020.

в вС, "Kenya Attack: 147 Dead in Garissa University Assault", April 3, 2015. https://www .bbc.com/news/world-africa-32169o8o. Last accessed May 10, 2020.

"Bereishit Rabbah 49", Sefaria, https://www.sefaria.org/Bereishit_Rabbah.49?lang=bi. Last accessed May 10, 2020.

Berg, Eric van den. "The Passion Gouda: Jezus sterft zonder borrelnootjes". April 21, 2011. https://www.mediakathedraal.nl/the-passion-gouda-jezus-sterft-zonder -borrelnootjes/. Last accessed May 10, 2020.

Berg, Eric van den. "The Passion Gouda: Jezus sterft zonder borrelnootjes II". April 21, 2011. https://www.mediakathedraal.nl/the-passion-gouda-jezus-sterft-zonder -borrelnootjes-ii/. Last accessed May 10, 2020.

Bible. New Revised Standard Version, available at https://www.biblegateway.com. Last accessed May 10, 2020.

Billboard, "Score: New Passions", September 29, 2001, https://bit.ly/2q47ybJ. Last accessed May 10, 2020.

De Telegraaf. "EO de mist in met Dave Roelvink", April 1, 2015. https://www.telegraaf .nl/entertainment/837013/eo-de-mist-in-met-dave-roelvink. Last accessed May 10, 2020.

De Volkskrant, "Tijd voor vrouwelijke Jezus in The Passion”, March 26, 2016, https:// www.volkskrant.nl/nieuws-achtergrond/tijd-voor-vrouwelijke-jezus-in-the-passion $\sim$ bf87aod9/. Last accessed May 10, 2020. 
“Émile Durkheim (1858-1917)", Internet Encyclopedia of Philosophy. A Peer-reviewed Academic Resource, http://www.iep.utm.edu/durkheim/. Last accessed May 10, 2020.

EnToen.Nu. Canon van Nederland. "Canon van Enschede". https://www.entoen.nu/nl/ overijssel/twente/enschede/vuurwerkramp-. Last accessed May 10, 2020.

EO/KRO, "Activiteiten", http://www.thepassion.nl/activiteiten. Last accessed August 15, 2016.

EU Observer. "EU states favour Christian migrants from the Middle East", https:// euobserver.com/justice/129938 August 21, 2015. Last accessed 1 October 2019.

European Court of Human Rights Grand Chamber. Case of Lautsi and Others $v$ Italy Judgement. March 18, 2011. http://hudoc.echr.coe.int/eng?i=001-104040. Last accessed May 10, 2020.

"Finale van The Passion 2015 vanuit de regiewagen", The Passion, April 4, 2015, YouTube. https://www.youtube.com/watch?v=kkGfcFB8r-8. Last accessed May 10, 2020.

"Frank Boeijen - Zeg me dat het niet zo is", Financiële Planning Voor Iedereen, last updated October 7, 2017, https://www.fpvi.nl/uitvaartmuziek/zeg-me-dat-het-niet -zo-is/. Last accessed May 10, 2020.

“Geef mij je angst”. André Hazes. http://www.songteksten.nl/songteksten/333o/andre -hazes/geef-mij-je-angst.htm. Last accessed May 10, 2020.

"GKv werkt mee aan 40-tal kerkplantingsprojecten", Gereformeerde Kerken vrijgemaakt. https://www.gkv.nl/gkv-werkt-mee-aan-40-tal-kerkplantingsprojecten/. Last accessed October 4, 2019.

"Interview Tommie Christiaan als Jezus in The Passion 2018", Zin in Vandaag (кRO), March 19, 2018, https:/www.televizier.nl/amusement/tommie-christiaan-a-the -passion-is-voor-iedereena. Last accessed August 19, 2019.

"Jakhals Erik over The Passion", Evangelische Omroep, April 13, 2011, YouTube. https:// www.youtube.com/watch?v=x7 GdgfcV 7 JY. Last accessed May 10, 2020.

"Je bent niet alleen" available on https://songteksten.net/lyric/2430/91927/thomas -berge/je-bent-niet-alleen.html. Last accessed May 10, 2020.

"Kerncijfers", KASKi Radboud Universiteit, http://www.ru.nl/kaski/onderzoek/cijfers -overige/virtuele_map/kerncijfers-2012/. Last accessed May 10, 2020.

“Kijk omhoog”. Nick en Simon. http://www.songteksten.nl/songteksten/76349/nick--simon/kijk-omhoog.htm. Last accessed May 10, 2020.

"Laren, H. Jan (Johannes) de Doper", Meertens Instituut, http://www.meertens.knaw .nl/bedevaart/bol/plaats/422. Last accessed May 10, 2020.

"Lord's Day 35", Heidelberg Catechism, http://www.heidelberg-catechism.com/en/ lords-days/35.html. Last accessed May 10, 2020.

"Losing faith?". NatCen Social Research, http://bsa.natcen.ac.uk/latest-report/british -social-attitudes-28/religion.aspx. Last accessed May 10, 2020.

"Marijke Helwegen", Wikipedia The Free Encyclopedia, July 12, 2016. https://nl .wikipedia.org/wiki/Marijke_Helwegen. Last accessed May 10, 2020. 
Metro. "The Passion is bewegende glossy voor stad". April 2, 2015. https://www .metronieuws.nl/binnenland/2015/o4/the-passion-is-bewegende-glossy-voor-stad. Last accessed May 10, 2020.

"Missie Evangelische Omroep", Evangelische Omroep. https://portal.eo.nl/over-de-eo/ missie-en-bestuur/missie/. Last accessed May 10, 2020.

Munsterman, Hendro and Mirella Klomp, "Briefwisseling The Passion". NieuwWij, April 7, 2015, http://www.nieuwwij.nl/verdieping/briefwisseling-the-passion-de -eerste-brief/ and consecutive letters. Last accessed May 10, 2020.

N.A.w. Plus, Onderzoek religie en levensbeschouwing thema Pasen (2009). http://www .nawplus.nl/images/fck/File/Onderzoek\%2oPasen.pdf. Last accessed December 7 , 2017.

N.A.w. Plus, Onderzoek religie en levensbeschouwing thema Pasen (2010). http://www .nawplus.nl/images/fck/File/Onderzoek\%2oPasen\%2O2010.pdf. Last accessed December $7,2017$.

$N U$, “Dave Roelvink vervolgd voor diefstal en heling”, March 25, 2015. http://www.nu.nl/ achterklap/4018720/dave-roelvink-vervolgd-diefstal-en-heling.html. Last accessed May 10, 2020.

"Omstreden Martijn Fischer klaar voor rol van Jezus in The Passion", ShowNieuws, February 22, 2016, https://www.shownieuws.nl/video/clips/2016/omstreden -martijn-fischer-klaar-voor-rol-van-jezus-passion/. Last accessed May 10, 2020.

"Passions door het hele land", March 30, 2015. Protestantse Kerk in Nederland. http:// www.protestantsekerk.nl/actueel/Nieuws/nieuwsoverzicht/Paginas/Passions-door -het-hele-land.aspx. Last accessed October 30, 2019.

Pew Research Center. "America's Changing Religious Landscape”. May 12, 2015. Washington D.C. Pew Forum on Religion and Public Life. Complete report available at http://www.pewforum.org/2015/05/12/americas-changing-religious-landscape/. Last accessed May 10, 2020.

"Processie is soort grote schoonmaak", EO Visie, March 20, 2015, video. https://visie.eo .nl/2015/o3/processie-is-soort-grote-schoonmaak/. Last accessed May 10, 2020.

RIVM, "Bijna veertig procent van de volwassen Nederlanders voelt zich eenzaam", September 30, 2013. https://bit.ly/2MrHct9. Last accessed May 10, 2020.

Rogers de Waal, Joel, "Western/MENA attitudes to religion portray a lack of faith in common values", YouGov, February 3, 2019. https://yougov.co.uk/topics/ international/articles-reports/2019/o2/o3/westernmena-attitudes-religion-portray -lack-faith-. Last accessed May 10, 2020.

RTL Late Night, “Jeroen herhaalt huzarenstukje The Passion” https://www.rtl.nl/video/ o34befig-ef26-b2e8-974f-f32oa39fb927. Last accessed May 10, 2020.

Schmeets, Hans, Wie is religieus en wie niet? Statistic Trends (СBs), oktober 2018 (PDFfile), obtained via https://www.cbs.nl/en-gb/news/2018/43/over-half-of-the-dutch -population-are-not-religious. Last accessed May 10, 2020. 
“Second screen". Oxford Dictionary. http://www.oxforddictionaries.com/definition/ english/second-screen. Last accessed May 10, 2020.

"Second Screen", Wikipedia The Free Encyclopaedia. https://en.wikipedia.org/wiki/ Second_screen. Last accessed May 10, 2020.

"Share of viewing". Glossary of Commonly Used Industry Terms, BAR B. http://www .barb.co.uk/resources/barb-facts/glossary?_s=4. Last accessed May 10, 2020.

"Statement by Prime Minister Mark Rutte on the attacks in Brussels", Government of the Netherlands, March 22, 2016, https://www.government.nl/latest/news/2016/o3/ 22/statement-by-prime-minister-mark-rutte-on-the-attacks-in-brussels. Last accessed May 10, 2020.

"Statistische jaarbrief en tabellenboek 2017.pdf", Protestantse Kerk in Nederland. https://www.protestantsekerk.nl/over-ons. Last accessed May 10, 2020.

The Economist. "Diverse, desperate migrants have divided European Christians", http:// www.economist.com/blogs/erasmus/2015/o9/migrants-christianity-and-europe September 6, 2015. Last accessed May 10, 2020.

The Guardian, "France's Burkini Ban Exposes the Hypocrisy of the Secularist State", August 24, 2016. https://www.theguardian.com/commentisfree/2016/aug/24/france -burkini-ban-secularist-equality-muslim?CMP=fb_gu. Last accessed May 10, 2020.

"The Manchester Passion 2006", Eddie Pearson, streamed on May 2, 2011, YouTubevideo, 59:52, https://www.youtube.com/watch?v=UAfLCV9ZeZY. Last accessed May 10, 2020.

The New York Times, "Strikes Claimed by Is Is Shut Brussels and Shake European Security", March 22, 2016, https://www.nytimes.com/2016/o3/23/world/europe/brussels -airport-explosions.html. Last accessed May 10, 2020.

"The Passion". NPOStart. Nederlandse Publieke Omroep. https://www.npostart.nl/the -passion/VPWON_1289791. Last accessed May 10, 2020.

“'The Passion' als verbinder", Spreekbuis, April 16, 2019, https://www.spreekbuis.nl/the -passion-als-verbinder/. Last accessed May 10, 2020.

"The Passion 2016 in audio en video", NPO Radio 2, March 24, 2016, https://www .nporadio2.nl/nieuws/11261/the-passion-2016-in-audio-en-video. Last accessed May 10, $202 \mathrm{O}$.

"Tickets processie The Passion uitverkocht", http://www.kro-ncrv.nl/inspiratie/ nieuws/370-37188-tickets-processie-the-passion-uitverkocht. Last accessed January 26, 2016.

“Transfer". Oxford Dictionary. https://www.lexico.com/en/definition/transfer. Last accessed May 10, 2020.

"Transformation". Oxford Dictionary. https://www.lexico.com/en/definition/ transformation. Last accessed May 10, 2020.

"VIDEO: The Passion in Amersfoort", NPO Start, http://www.npo.nl/video-the-passion -in-amersfoort/o3-o9-2015/POMS_EO_1870034. Last accessed May 10, 2020. 
vVV Amersfoort, “The Passion 2016", http://www.vvvamersfoort.nl/The-Passion-2016. Last accessed May 1, 2016.

"Wijzigingen: Martijn Fischer", Wikipedia, version of February 2, 2016, https://nl .m.wikipedia.org/wiki/Speciaal:MobielVerschillen/45913837. Last accessed May 10, 2020.

“Winnaars de TV beelden 2014". De TV Beelden. http://detvbeelden.nl/winnaars/ winnaars-2014/. Last accessed May 10, 2020.

"Zwart-wit". Frank Boeijen Groep. https://www.songteksten.nl/songteksten/14124/ frank-boeijen/zwart-wit.htm. Last accessed May 10, 2020. 


\section{Index}

Abraham 193-194

Academic research 6, 15, 54, 139n, 199n

As play 187, 201-202

Aegeria/Etheria 59

Ambiguity 97, 106-107, 112-113, 127-134, 155, $191,192 \mathrm{n}$

Ambivalence $58,86,106-107,156,158-159$, 191, 194, 198n, 201

Ammerman, Nancy $\quad 121-124,127-135$ See also Sacred consciousness

Ana-liturgy/ana-liturgical ritual $\quad 84-86,89$, 91

Anatheism $\quad 6,77,82-86,86 n$

And imagination $\quad 8 \mathrm{n}, 82,84,208$

See also Kearney

Appadurai 66-69, 96

See also-Scapes

Artistic research as epistemological resource 15

Audience XIII, 24n, 26, 29n, 34, 38-51

See also The Passion, Liquid aspects

Authority 100, 122, 127, 138, 179, 191n

Bach, Johann Sebastian 6o

Barabbas 34, 131-133, 140, 148, 15on, 156-158, 161,165

Barnard, Marcel, Johan Cilliers and Cas

Wepener 12, 13n, 16, 58n, 69n, 91, 10on, 142, 205n

Basic sacral $\quad 56-57,97 n, 112$

Bauman, Zygmunt $\quad 58,123,126,135$

See also Liquid Modernity

See also Liquid Society

Beaudoin, Tom 2n, 197-199, 20on

Belief/disbelief $\quad 1,2 n, 3-4,7,37,75-76,82,84$, 91, 122, 146, 152, 192, 196-197, 199, 202

Brown, Callum $\quad 5,122,124$

Campbell-Reed, Eileen $\quad$ 12, 209-211

Casanova, José 12on, 145, 146n

Case studies 11-12

Castells, Manuel 66n, 69n, 100 See also Plural authority structure

Casting/typecasting $\quad 129,155,157$

Christianity

Disappearing/receding $\quad 2-3,56$

In the global South 5
In the Netherlands 1-10, 52

In the West $11,54-56$

Transfer of 57

See also Transfer

Transformation of $\quad 52,57$

See also Transformation

Church members/church membership 4, 5 n, 27, 55, 73, 75, 179, 186, 195, 220

City marketing $\quad 42,106,110,172$

Cocktail nuts (metaphor) 48, 110, 118

Collective effervescence $\quad 51$

See also Durkheim

Contemporary Christian Music (ссм/'relipop') 65

Contested/contestation 14, 15, 97, 100, 105-107, 111-112, 145, 147, 159-16o, 189-190, 193-194

Cover songs $\quad 30-32,45$

Cross-bearers $\quad 29,35,78,87,89,212$

De-churching 4, 39

Depillarisation/pillarisation in Dutch culture $51,62,122$

Destabilising notions of faith 199

Deus ludens 136-137, 192-193, 203

Digital media $14,40,42$, 52, 120-132, 134, 159, $178,190,207-208$

Ambiguities of 127

Characteristics of 127

Droogers, André $\quad$ 120n, 121, 124-125, 128

Durkheim, Emile 6n, 51, 98-99, 123, 142

Ecclesial domain/extra-ecclesial domain 6, 54, 57-59, 65, 67, 71, 73, 179, 200

Encounter with the divine/God 8, 72n, 73, 76-77, 82-83, 86-88, 90-92, 112, 116-117, 199, 203

Epiphany/epiphanic character 90-91

Epistemological position $12,16,205^{-2} \mathrm{O} 7$

Ethno-case study 11, 189, 199, 208-212

See also Parker-Jenkins

Ethnomusicology $\quad 54-55,71$

Fauconnier, Gilles 104

See also The Passion as mental space

Fides quaerens figuras 91

Firemen 86-88, 184 
Floating believers 5on, 56, 194

Flyvbjerg, Bent 11-12, 212n

Frissen, Valery et al. 121, 124n, 125-133

Genesis 114-117, 192-193

Genesising $\quad 136$

God

After 6-11, 17, 73-77, 82-84, 199, 202-2O3

As a late-comer

See also Leeuw, van der 199

Between the sheets $\quad 115$

Change of 88

Death of 6-10

In a glitzy event and silly occasions $\quad 118$

Image of $87,164 \mathrm{n}$

Letting go of $75,83,89-90$

Negotiating with 193-194

Possibility of God after $\quad 77,82,84-85,89$, 117,203

Reappearance of 14, 85

Rethinking (afresh) 6, 21, 93

Traces of 9, 11, 17n, 19, 115, 192, 194, 197, 199, 205

Waits for people 193-194, 196

Weakness of 88

God in Nederland (GIN) questionnaire 3, 4on, 44-51, 75-77, 85, 217-225

Goliath the Chihuahua dog 129

'Good religion - bad religion' narrative $\quad 145$ $156,159,161$

Graham, Elaine 2n, 7n, 26n, 166n

Grimes, Ronald $\quad$ 96, 97n, 99, 124n, 181-182

See also Ritual Criticism

Guantanamo Bay 131, 151-153

Guest $84,115,185-186$

Heritage $18,31,42,52,55,62,76,140$, 144-147, 16o, 178-179, 189

Hermeneutical faculty to deal with the sacred 121-125, 131, 134-135

Holy insecurity 89

Homo ludens

See also Huizinga 14, 124n, 126, 137, 193

Hope $\quad 88,154,156,165,170-172,191,197$

Hostility or hospitality $\quad 84,203$

Huizinga, Johan $124 \mathrm{n}, 126$

Human faculty of play 121, 123-125, 131, 134

Human flourishing 92

Humour 120, 129-130, 137
Hymnology 71-73

Identity 140

And politics in Europe 147

Concept of 120

Construction/reconstruction of 122,126 , 130,198

National 15, 139, 141-147, 158, 161, 165, 222

Religious 130, 135

Resistance 58n, 110

Trying on 123

Image and likeness $\quad 136$

Institutionalised Christianity/church $\quad 4,14$, $7,14,5$ o, 52-57, 58n, 64, 71

ISIS 131, 134, 151-154

Islamisation $131-132,156$

Islamophobia $\quad 15,139,143 n, 145 n$

Jesus-image $\quad 140,148-156,159,161,170 \mathrm{n}$

As a white autochthonous Dutch man 150

John $\quad 32,175$

Juchtmans, Goedroen $\quad 56 n$, 97n

Kaufman, Tone Stangeland $\quad 76$

Kearney, Richard $\quad 6-7,77,82-86,88,90-92$, 202, 208

See also Anatheism

Leeuw, Gerardus van der 198 See also God as a late-comer

Lefebvre, Henri $\quad$ 96, 100

Letter of objection against The Passion 108-109

Liminality and ritual $\quad 124,141,143$

Line-up 32, 87n, 214

See also The Passion, Format

Liquid

Church $5^{8}$ See also Ward

Modernity 58, 63-64, 69n See also Bauman

Society 13, 15, 120, 123, 126

See also Bauman

Live TV show $23-28,29 n, 32 n, 35,39,54,64$, $74 \mathrm{n}, 108,212$

Location 36

See also The Passion, Liquid aspects

Locus iste 114-118 
Lord of the play 136

Loss $37,82,107,179,194-195$

Ludification of culture 120,125

Luke 174

Lynch, Gordon $\quad 6 n$, 10n, 26n, 98-99, 124n, 142, 159n

McAlister, Elizabeth $\quad$ 53n, 66-67

See also Religioscapes

McClure, John $\quad 68,176-178,181$

Mediatisation 143, 210n

Meta-social rites 140,141 143, 159, 161 See also Turner

Motto 37

See also The Passion, Liquid aspects

Mul, Jos de 120n, 126

Music and narrative 36

See also The Passion, Liquid aspects

Negotiation $8 \mathrm{n}, 12,112,117,123,137,155 \mathrm{n}$, 181n, 189-194, 201

Network society/-ies $\quad 11,18,21,73,82,96,120$

Nietzsche, Friedrich 3

Non-Western 2, 37

Nongbri, Brent 9

Normativity 14, 18, 76-77, 85, 142-143, 195

Numeri 163

Openness

Of God 199n

Of mind 19

Of theological concepts 9

Towards extra-ecclesial practices 73

Towards the procession/cross $77,85,92$

Oppositions (binary) 111

Orange jumpsuit/coverall 131-133, 148, 150-155

Ordinary

Retrieving the extra-ordinary in the 84 , $89,91,92$

Osmer 13, 16, 206-207

Other, the $10,192,170,186,192-197$

Paradox 5n, 9, 63, 76, 135, 162

Parker-Jenkins 11n, 208-212, 210n See also Ethno-case study

Passion (as musical form) 54 200o Project 61
As compassion 59

As doctrina and contemplation 59

As imitation/identification 60

As memoria 59

History of the practices of $\quad 54,58-66$

Revival of the 61

Tradition of the 54

Pendulum/oscillation 63

Play

'As-if' character of 130

As a metaphor 13

Definition of 124-125

Medieval Passion $121 n$

Practical theology as 189-203

Religion and/as 120-135

Ritual-musical 13

Playing field $\quad 121,124$

Plural authority structure $\quad$ 10on, 179

See also Castells, Manuel

Performers 36

See also The Passion, Liquid aspects

Pew Research Center 5n, 56n

Poetics (/Theopoetics) 16, 85, 91

See also Walton

Positionality of the researcher 18, 211

Post, Paul $\quad 6,55 n, 56,8$ on, 81, 96, 98, 143

See also Sacred, Domains/fields of the

Post-Christian 3, 7, 97, 113

Post-secular $\quad 7,92,113,121,144-147,160$

Practical theology

And creativity/imagination $\quad 16$

As (academic) play $\quad 198-203$

As public theology $71,167,180$

Contribution to the development of 189, 196-200

Embodied 166, 183

In the Netherlands 7n, 73

The discipline of $72 \mathrm{n}$

Theoretical concepts in 54,55

Practices of faith

Definitions of 197

Fluid 55

Presentia realis 91

Processes of secularisation 1

Procession 27-28, 35, 74-92, 101-103

Public

Discourse $\quad 1,200,201 n, 210$ 


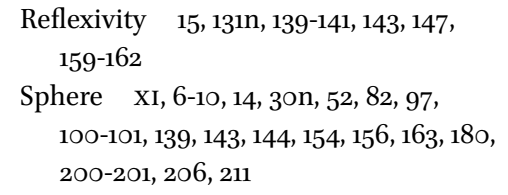

Theology 15, 71, 166-183, 200-201

Quantitative research $\quad 3-4$

Quest for God 6-10, 13, 18, 77, 186, 189, 198-199, 201-203, 207, 211

Radical theology 7,77

Religion

As a bargaining game 190

Complexity of contemporary $\quad 14,160$

Definitions of 9,10

Engendering and channelling public debate 133

Fluidisation of 55

Religioscapes 53n, 66-67

See also McAlister

Religious-secular dichotomy/divide 2n, 9, 120, 135, 159

Religious

Experimentation $\quad 28,124$

Landscape $5 \mathrm{n}, 14,21,54,55-58,61,65-66$, $73,82,120-122,140$

'Nones' 5

Return of the divine/of God/to God 8n, 76-77, 82-89, 92, 185, 194, 203

Ritual 13

Criticism 18, 124n, 18o-182 See also Grimes

Infelicity $\quad 181-182$

With Christian roots $14,57,103,121,134$, 177,192

Ritual and Liturgical Studies $\quad 6,7,181$

Rooden, Peter van $\quad 56-57,122,124$

Sacrality $\quad 6,56-57,96,99,107,110,112,123,191$

Sacramental $\quad 76,77$

Encounter with God $\quad 77,85,91$

Imagination 82, 84, 208

Inversion 91

Pillow 116

Quality of ritual $\quad 76$

Return to the holiness of the everyday 82,89
Understanding of ritual $\quad 208$

Sacred

Concept of the 6, 10, 99, 191-192

Consciousness 121-123, 127, 135 See also Ammerman

Construction of the 6,123

Domains/Fields of the $6,5^{6-57}$ See also Post

In the 'negative' ${ }^{115-116}$

Reappearance of the 85

Set apart character of $82 n, 98-99,112$

Sacro-soundscapes 69-73

Notion of 69

Study of 71

Sacro(-)scapes $\quad 66-67,72$

See also Tweed

-Scapes 66-69, 96

See also Appadurai

Schippers, Inez 57n, 97n, 98n, 99n, 10on, 106

Schulz, Dorothea $\quad 67 n, 68-69$

See also Soundscape

Secularisation $\quad 1-5$

Church attendance and $\quad 4,56,58,184$, 186

Thesis $\quad 1,2,8$

Self-understanding of society $\quad 138-165$

Separation of church and state 110-111

Sermonette 169

Societal debates $140,156,159$

Soundscapes $67 \mathrm{n}, 68,69 \mathrm{n}$

See also Schulz

Space

Contested 97, 100, 105, 106, 112, 194

Musical 102-103, 110

Physical 101, 107-110

Place and the sacred $\quad$ 98-105

Politicised 101

Ritual 101, 102, 107-108, 110-111

Sacralising Public 96, 99

Spatial practice, concept of 101

Spirituality

Of dwelling/seeking $\quad 8,65,112,191,197$

See also Wuthnow

Stability/instability $\quad 58,142,191$

Statistics Netherlands (Свs) 4

Status reversal $141,157 \mathrm{n}, 158-159,165$

Stranger $\quad 9 n, 83-86,89,89-90,115,185,203$ 
Stringer, Martin 10

Subjunctively 125, 202

Surprise $\quad 24,39,114-115,117,172,175,182-183$, 192

Taylor, Charles $\quad 2$

The Netherlands Institute for Social Research (SCP) $\quad 4,47$

Theism $75,83-84$

Theories 12

Construction of 12

Dynamic 13

Theology

After (the death of) God 76, 196-20o

And Sachkritik $\quad 18$

As academic discipline $\quad 187$

As a practice by various practitioners $\quad 15$

As construction 15,18 o

Of presence $\quad 176$

The Passion

And the 'after Passion' 35

And its economic context 42

As a missionary event 111

As broadcast 24

As contested practice 14

As ludic practice 119-135

As mental space 102

See also Fauconnier

As musical and physical space $\quad 102$

As practice of negotiation 201

As ritual performance 9

As ritual space 102

As spatial practice 14, 100-101

As staged theology 176,181

As temporary dwelling in a sacro-soundscape 70,95

Criticism of 48

Format of 30-35

Liquid aspects of $\quad 35-38$

Local performances of 64

Manchester 26, $15^{2}$

New Orleans 212-215

Organisers/producers of $14,27,38$

Reception by the public of $43-51$
Societal and political topics in $147 \mathrm{n}$

Success factors of $38-41$

Viewing figures of 21

'Traditional' $4,14,55,58,64,75,75 \mathrm{n}, 76,77$,

$84,91,147,196,199 n, 208$

Transfer 30

Of religion 57

See also The Passion, Format

Transformation 31

Of society 5

Of religion $\quad 6,7,21 \mathrm{~m} 187$

Of religious forms 13

See also The Passion, Format

Transversality 12, 13, 207

See also Osmer

Turn

Anatheist 89

Ludic 126-127

Spatial 96-97

Turner, Victor 124, 125, 131n, 139-144, 147-148, 156n, 158-159

See also Meta-social rites 141

Tweed, Thomas $\quad 12,66-67,69,72,95$

See also Sacro(-)scapes

Use of Scripture $\quad 15$

Von Fischer, Kurt $\quad 59 n, 6$ on

Wager

Abraham's 193

Anatheistic $83-85,89-90$

God as 201-203

Playful 194

Uncomfortable/inconvenient 196

Walton, Heather 16

See also Poetics

Ward, Pete 58n, 72n, 196n See also Liquid Church

Wijnia, Lieke $\quad 6 n, 10 n, 57 n, 65 n, 70 n, 72 n$, 97n, 98-99

Wilson, Erin $144 n, 145,146 n$

Worldview 2n, 56, 68, 75, 197, 202

Wuthnow, Robert $\quad 8 n, 65,112 n, 191,197 n$ 


\section{Permissions}

Chapter 2, with kind permission from the Institute for Ritual and Liturgical Studies (PThU, Amsterdam) and DeGruijter:

Mirella Klomp, "Joseph \& Jesus. Bible-based musicals and contemporary Passions staged in the public domain: an exploration of a research perspective", Yearbook for Liturgical and Ritual Studies 27 (2011): 49-65.

Mirella Klomp and Marcel Barnard, "Sacro-Soundscapes. Interpreting Contemporary Ritual Performances of Sacred Music through the Case of The Passion in the Netherlands", International Journal of Practical Theology 21/2 (2017), 240-258. DOI: 10.1515/ijpt-2016-oo3o.

Chapter 3, with kind permission from Sage:

Mirella Klomp and Danie Veldsman, "After God, But Behind the Cross. The Procession as a Way to Re-encounter God in a Culture Beyond Classical Liturgy", Studia Liturgica. An International Ecumenical Review for Liturgical Research and Renewal 47, no. 1 (2017), 15-29.

Chapter 4, with kind permission from Africa World Press:

Martin Hoondert and Mirella Klomp, "The Streets of Gouda", in Paul Post, Philip Nel and Wouter van Beek (eds.), Sacred Spaces and Contested Identities. Space and ritual dynamics in Europe and Africa. Trenton, NJ: Africa World Press, 2014, 313-33o.

Chapter 5, with kind permission from Taylor and Francis:

Mirella Klomp and Marten van der Meulen, "The Passion as ludic practice", Journal of Contemporary Religion 32, no. 3 (2017), 387-401. DOI: 10.108o/ 13537903.2017.1362879.

Chapter 6, with permission from Brill:

Mirella Klomp, Marten van der Meulen, Erin Wilson and Anita Zijdemans, "The Passion as Public Reflexivity: How the Dutch in a Ritual-musical Event Reflect on Religious and Moral Discussions in Society", Journal of Religion in Europe 11 (2018), 195-221. DOI: 10.1163/18748929-01102007.

Chapter 7 , with permission from Brill:

Mirella Klomp, "Staging the Resurrection: The Public Theology of Dutch Production and Broadcasting Companies". International Journal of Public Theology $9 / 4$ (2015), 446-464. 